Nevada

Environmental

Restoration

Project

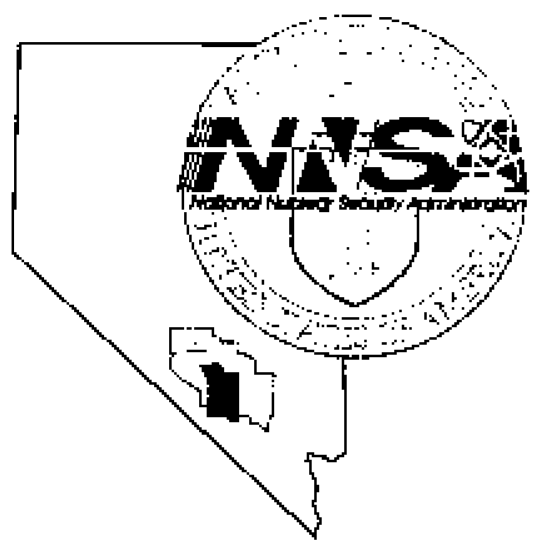

Closure Report for

Corrective Action Unit 143:

Area 25 Contaminated Waste

Dumps,

Nevada Test Site, Nevada

Controlled Copy No.:

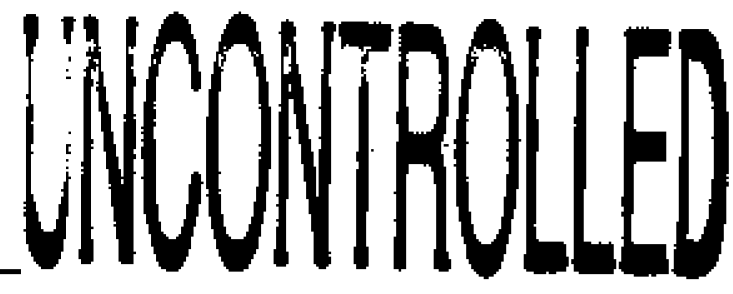

Revision: 0

March 2002

Environmental Restoration

Division 


\section{DISCLATMER STATEMENT}

Reference herein to any spccific commercial product, process, or senvice by trade name, trademark, manufacturer, or otherwise, docs not necessarily constitute or imply its codorsement. recommendation, or favoring by the L.S. Gowemment or any agency thereof or its contractors or subcontractors.

\section{AYAILABH,ITY STATEMENT}

Arailable for sale to the public from-

L.S. Department of Commerce

National Technical Information Service

5285 Port Royal Road

Springfield, VA $22161-0002$

Telephone: 800.553 .6847

Fax: 703.605.6900

E-mail: orders(ontis.fedworld.gov

Online ordering: http:/4ww.ntis.gow/ordering.htm

Available electronically at http/hww.doe.gow/bridge

Available for a processing fee to L'S. Department of Energy and its contractors, in paper, front-

U.S. Department of Energy

Office of Scientific and Technical Information

P.O. Box 62

Oak Ridge, TN 37831-0062

Telephone: 865.576 .8401

$\operatorname{Fax}_{7} 865.576 .5728$

E-mâli reports@oadonis.osti.gov 


\title{
CLOSURE REPORT FOR CORRECTIVE ACTION UNIT 143: AREA 25 CONTAMINATED WASTE DUMPS NEVADA TEST SITE, NEVADA
}

\author{
Prepared for the \\ U. S. Department of Energy \\ National Nuclear Security Administration \\ Nevada Operations Office \\ Work Performed Linder Contract No. DE-AC08-96NV11718
}

Controlled Copy Na.:

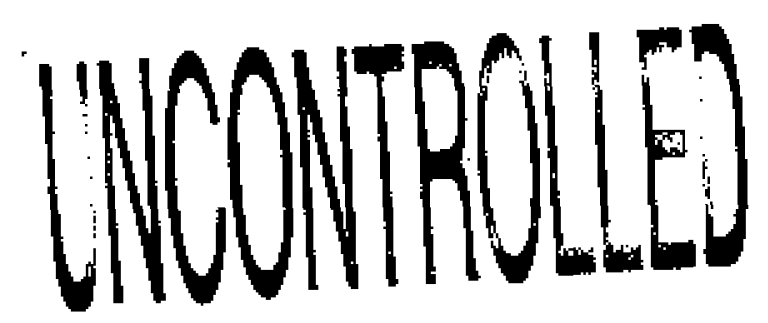

Revision: 0

March 2002 
THIS PAGE INTENTIONALLY LEFT BLANK

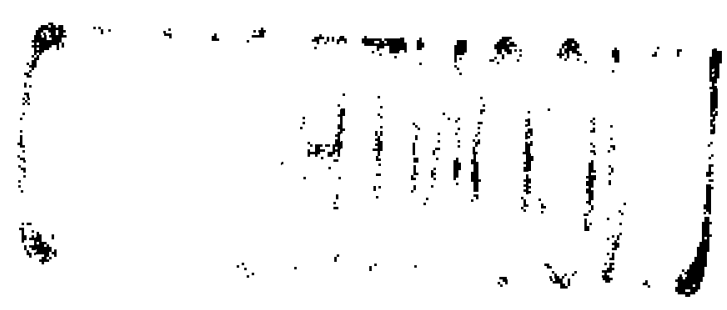




\section{CLOSURE REPORT FOR CORRECTIVE ACTION UNIT 143: AREA 25 CONTAMINATED WASTE DUMPS NEVADA TEST SITE, NEVADA}
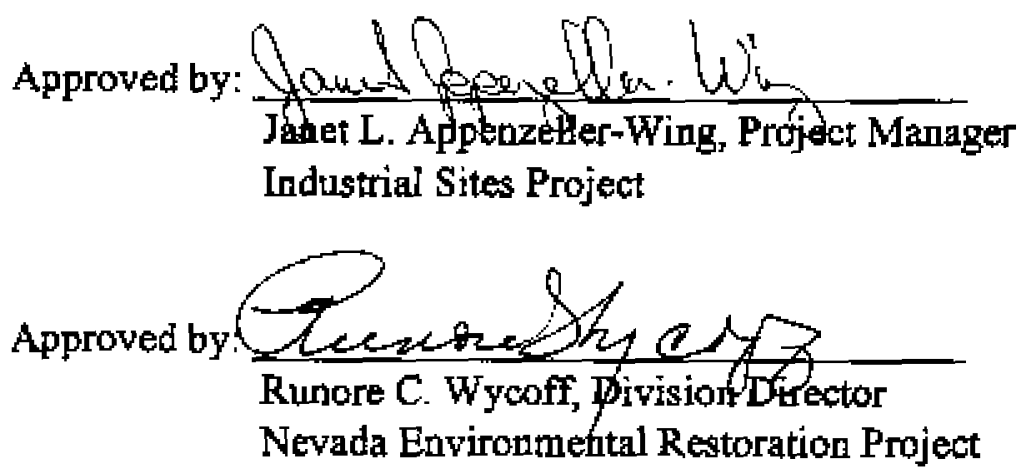

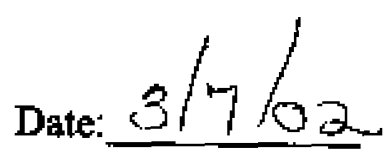

Date: $3 / 7 / 02$ 
THIS PAGE INTENTIONALLY LEFT BLANK 


\section{TABLE OF CONTENTS}

ACRONYMS AND ABBREVIATIONS $\ldots \ldots \ldots \ldots \ldots \ldots \ldots \ldots \ldots \ldots$

EXECUTIVE SUMMARY $\ldots \ldots \ldots \ldots \ldots \ldots \ldots \ldots \ldots \ldots \ldots \ldots \ldots \ldots \ldots$

1.0 INTRODUCTION $\ldots \ldots \ldots \ldots \ldots \ldots \ldots \ldots \ldots \ldots \ldots \ldots \ldots \ldots \ldots$

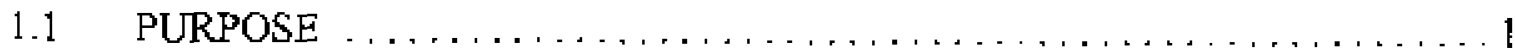

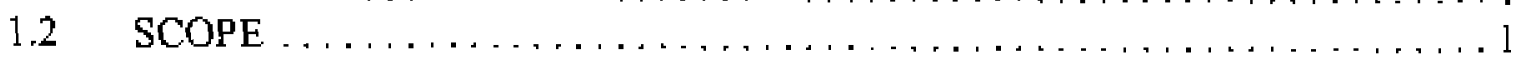

1.3 CLOSURE REPORT CONTENTS .................

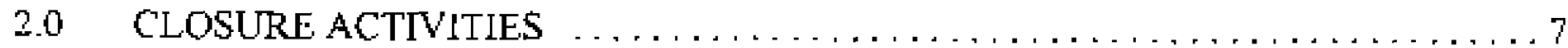

2.1 DESCRIPTION OF CORRECTIVE ACTION ACTIVITIES $\ldots \ldots \ldots \ldots \ldots .7$

2.1 .1 Removal of Sr-90 impacted Soil . . . . . . . . . . . . . . .

2.1.2 Level the R-MAD West Trench Berms to the Existing Grade . . . . . . . . 9

2.1.3 Back[1l the R-MAD East Trestle Area $\ldots \ldots \ldots \ldots \ldots \ldots \ldots \ldots \ldots, \ldots$

2.1.4 Erosion Protection Installation . . . . . . . . . . . . . . . . . . . . . . 13

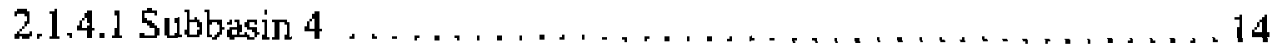

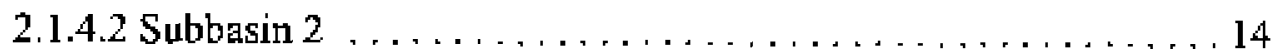

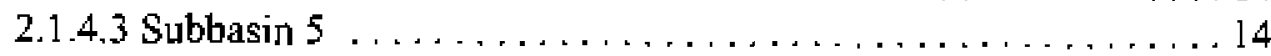

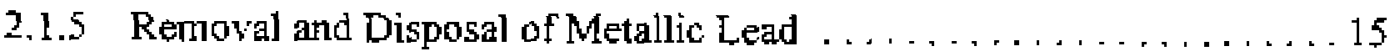

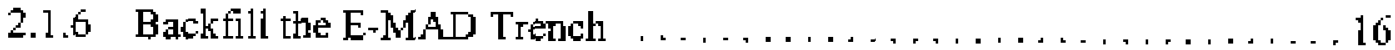

2.1 .7 Demobilization . . . . . . . . . . . . . . . . . . . 18

2.2 DEVIATIONS FROM CAP AS APPROVED $\ldots \ldots \ldots \ldots \ldots \ldots \ldots \ldots \ldots$

2.3 CAU 143 CLOSURE ACTIVITIES SCHEDLLE . . . . . . . . . . . 18

2.4 CAU 143 FINAL SURVEY "AS-BUILT" DRAWINGS . . . . . . . . 18

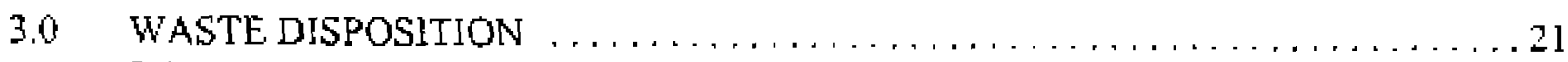

3.1 RADIOACTIVE WASTE (LOW-LEVEL WASTE) $\ldots \ldots \ldots \ldots \ldots \ldots \ldots$

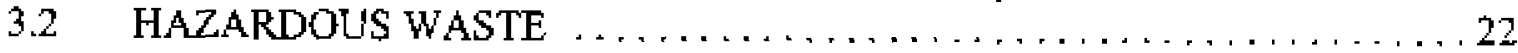

3.3 NONHAZARDOUS WASTE $\ldots \ldots \ldots \ldots \ldots \ldots \ldots \ldots \ldots \ldots$

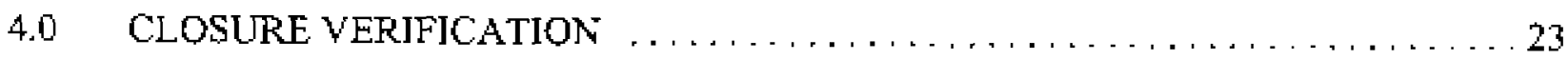

4 DATA QUALITY ASSESSMENT $\ldots \ldots \ldots \ldots \ldots \ldots \ldots \ldots \ldots \ldots$

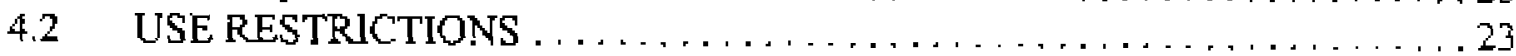

5.0 CONCLUSIONS AND RECOMMENDATIONS $\ldots \ldots \ldots \ldots \ldots \ldots \ldots \ldots \ldots \ldots$

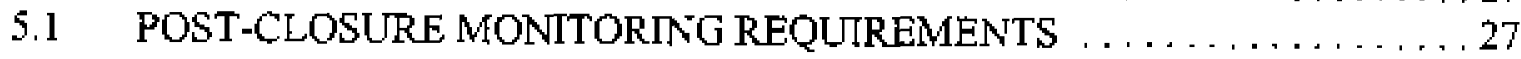

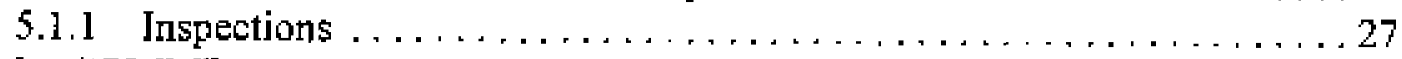

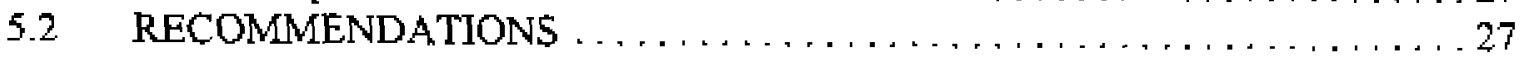

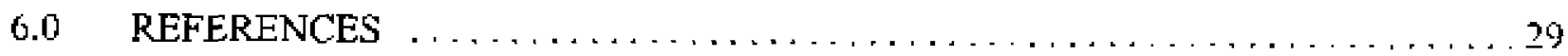




\section{TABLE OF CONTENTS (continued)}

\section{TABLES}

TABLE 1 - RADIOANAL YTICAL RESULTS FOR CONFIRMATION SOIL SAMPLES ， 24

TABLE 2 - ANALYTICAL RESULTS FOR LEAD CONFIRMATION SOIL SAMPLES . . 24

\section{FIGLRES}

FIGURE 1 - CAU 143 LOCATION MAP $\ldots \ldots \ldots \ldots \ldots \ldots \ldots \ldots \ldots \ldots \ldots \ldots$

FIGLRE 2 - R-MAD SITE LAYOUT MAP $\ldots \ldots \ldots \ldots \ldots \ldots \ldots \ldots \ldots \ldots$

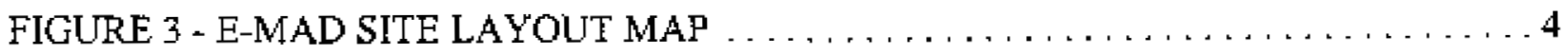

FIGURE 4 - R-MAD AERIAL PHOTOGRAPH BEFORE REMEDTAL ACTION $\ldots \ldots$

FIGURE 5 - E-MAD AERIAL PHOTOGRAPH BEFORE REMEDLAL ACTION $\ldots \ldots \ldots 17$

FIGURE 6 - CAU 143 CLOSURE ACTIVITIES SCHEDULE $\ldots \ldots \ldots \ldots \ldots \ldots \ldots$

FIGLRE 7 - CAU 143 SAMPLE LOCATIONS AND ANAIYTICAL RESULTS . . . . . . 25

\section{APPENDICES}

APPENDIX A - "AS-BUILT" DRAWINGS AND ENGINEERING CALCULATIONS FOR CAU 143: AREA 25 CONTAMINATED WASTE DUMPS

APPENDIX B - CONFIRMATION SAMPLING TEST RESURTS

APPENDIX C - CAU 143 GLOBAL POSITIONTNG SYSTEM COORDNNATES FOR GEOPHYSICS MARKINGS

APPENDIX D - CAU 143 RADIATION SURVEY REPORTS

APPENDIX E - CAU143 USE RESTRICTION INFORMATION

APPENDLX F - CAU 143 WASTE DISPOSITION DOCUMENTATION

APPENDLX G - FIELD PHOTOGRAPHS 


\section{TABLE OF CONTENTS (continued)}

APPENDIX H - NEVADA DIVISION OF ENVIRONMENTAL PROTECTION COMMENT RESOLUTION FORM

DISTRIBUTION LIST 


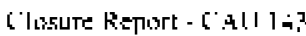

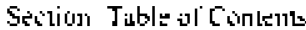

R-tistor: 0

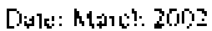

THIS PAGE INTENTIONALLY LEFT BLANK

viii 


\section{ACRONYMS AND ABBREVIATIONS}

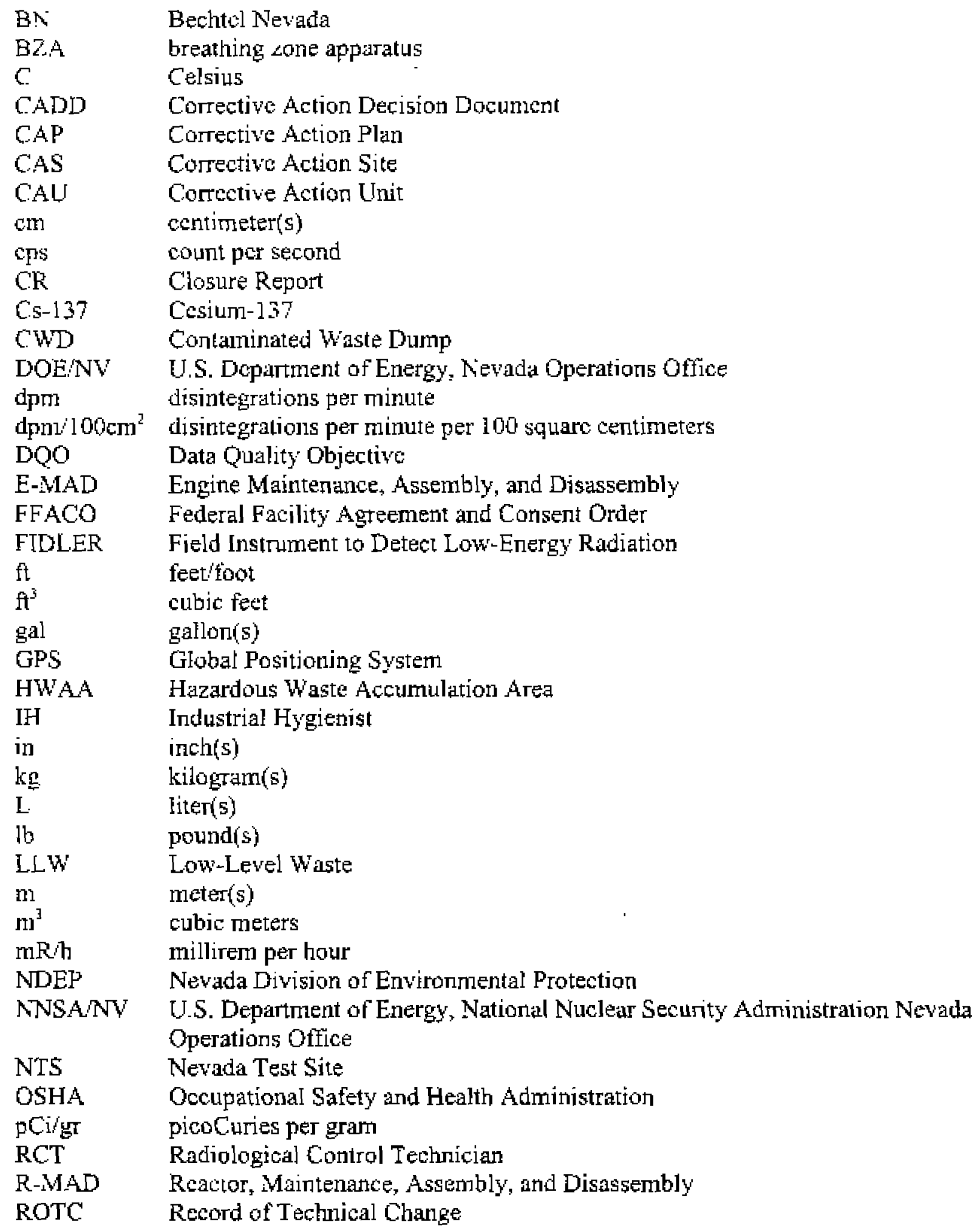




\section{ACRONYMS AND ABBREVIATIONS (continued)}

$\begin{array}{ll}\text { RWAP } & \text { Radioactive Waste Accptance Program } \\ \text { RWMS } & \text { Radioactive Waste Management Site } \\ \text { Sr-90 } & \text { Strontium-90 } \\ \text { TNT } & \text { Transient Nuclear Test } \\ \text { yd } & \text { cubic yards } \\ \text { yr } & \text { year(s) }\end{array}$




\section{EXECUTIVE SLMMARY}

Corrective Action Unit (CAU) 143 is located in Area 25 of the Nevada Test 5 ite. The unit is listed in the Federal Facility Agreenent and Consent Order (FFACO, 1996) as CAU J 43 which is comprised of wo Corrective Action Sites (CASs):

- CAS 25-23-69, Contaminated Waste Dump \#1 at the Reactor Maintenance, Assenbly, and Disassembly Facility

- CAS 25-23-03, Contaninated Waste Dump +2 at the Engine Maintenance, Assumbly, and Disassembly Facility

The approved corrective action altemative for this unit was closure in place with adminisirative controls. Closure activities included:

- Earthwork to fill depressions and grade to the natural slope

- The ase of additional clean cover soil as excess backfill

- Land use restrictions to minimize access and prevent unauthorized site activities.

- The construction of crosion control structures and placement of a diversion channel berm to divert slorm water runon'runoff potential and mitigate channelized erosion.

CAU I 43 was closed in accordance with the FFACO and the Nevada Division of Environmental Protection (NDEP)-approved Corrective Action Plan (CAP) for CAL 143: Area 25, Contaminated Waste Dumps, Nevada Test Site, Nevada (U.S. Department of Energy Nevada Operations Office [DOE/NV], 2001). The closure activities specificd in the CAP were based on the recommendations presented in the Correclive Action Decision Document (DOE/NV, 2000a).

The proposed post-closure monitoring plan consists of annual site inspections to detemine the condilion of fencing signage and postings. If any maintenance and repair requirements are identified, funding will be requested and the repairs scheduled. Any repairs will be documented in writing at the time of repair. Results of all inspections and tepairs for a given year will be addressed in a single report submitted annually to the NDEP. 
Closire Repar - CAC: I

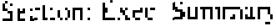

Raision: 0

Dile. Marili 200

THIS PAGE INTENTIONALLY LEFT BLANK 


\subsection{INTRODUCTION}

This Closure Report (CR) has been prepared for the Area 25 Contaminated Waste Dumps (CWD), Corrective Action Lnil (CALS) 143 in accordance with the Federal Facility Agreement and Consent Order [FFACO] (FFACO, 1996) and the Nevada Division of Environmental Protection (NDEP)-approved Cortcetive Action Plan (CAP) for CAL 143: Area 25, Contaminated Waste Dumps, Nevada Test Site, Nerada (U.S. Department of Energy, Narada Operations Office [DOE/NV], 2001). CAU 143 consists of two Cotrecive Action Sites (CASs): 25-23-09 CWD $\# 1$, and 25-23-03 CWD 42 .

The Area 25 CWDs are historic disposal units within the Arca 25 Reactor Maintenance, Assembly, and Disassembly (R-MAD), and Engine Maintenance, Assembly, and Disassembly (E-MAD) compounds located on the Nevada Test Site (NTS) (Figure 1). The R-MAD and E-MAD hacilities originally supported a portion of the Nucleas Rocket Development Station in Area 25 of the NTS. CWD \#1 CAS 25-23-09 received solid radioactive waste from the R-MAD Compound (East Trestle and West Trench Berms) (Figure 2) and 25-23-03 CWD H2 received solid radioactive waste from the E-MAD Compound (E-MAD Trench) (Figure 3 ).

\section{$1.1 \quad$ PURPOSE}

The Area 25 CWDs were identified as CAU 143 by the FFACO (FFACO, 1996). The purpose of this CR is to document that the closure of CAU 143 complied with all of the CAP closure requirements (DOE $\mathrm{NV}, 2001$ ).

\subsection{SCOPE}

The approved closure strategy for CAU 143 was specified in the Corrective Action Decision Document (CADD) for CAU 143: Area 25 Contaminated Waste Dumps, Nevada Tost Site, Nevada, (DOENN, 2000a). The approved alternative includes closure in place with administrative controls. The implemented closure strategy consisted of the following activities.

\section{R-MAD}

- The soil immediately surrounding the location of the elevatod strontium-90 (Sr-90) surface sample was removed prior to moving the Transient Nuclear Test (TWT) Mound (Figute 2),

- Earthwork at the East Trestle consisted of backfilling the trestle depression area with fill from each of the six West Trench bems, the TNT Mound, and from a borrow fill source nothwest of the R-MAD facility. The backfill material was placed to an elevation slightly above the existing track grade to eliminate depressions, while the existing slopes were modified to minimize nunoninunoff, infiltration, and possible erosion. 


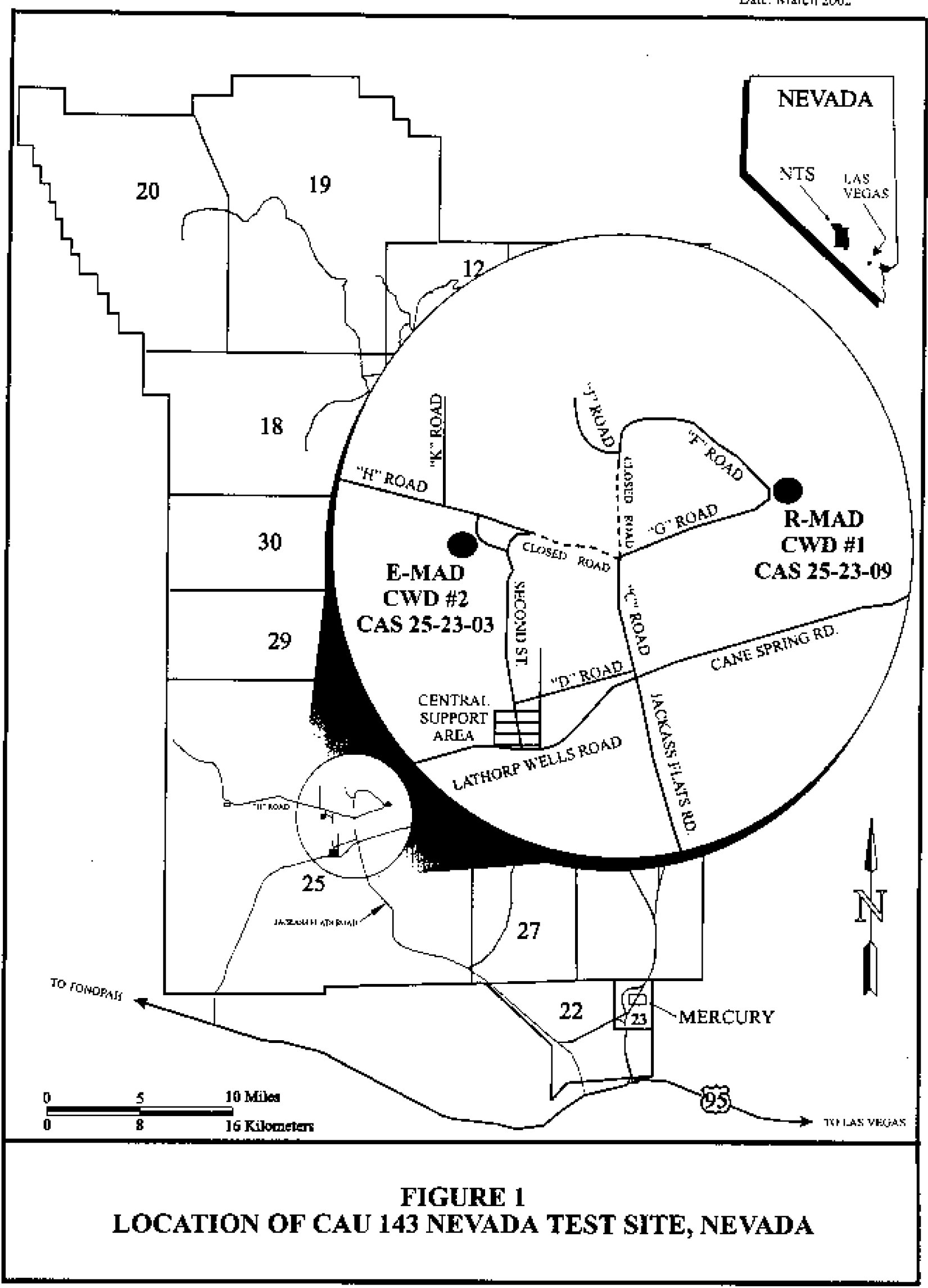




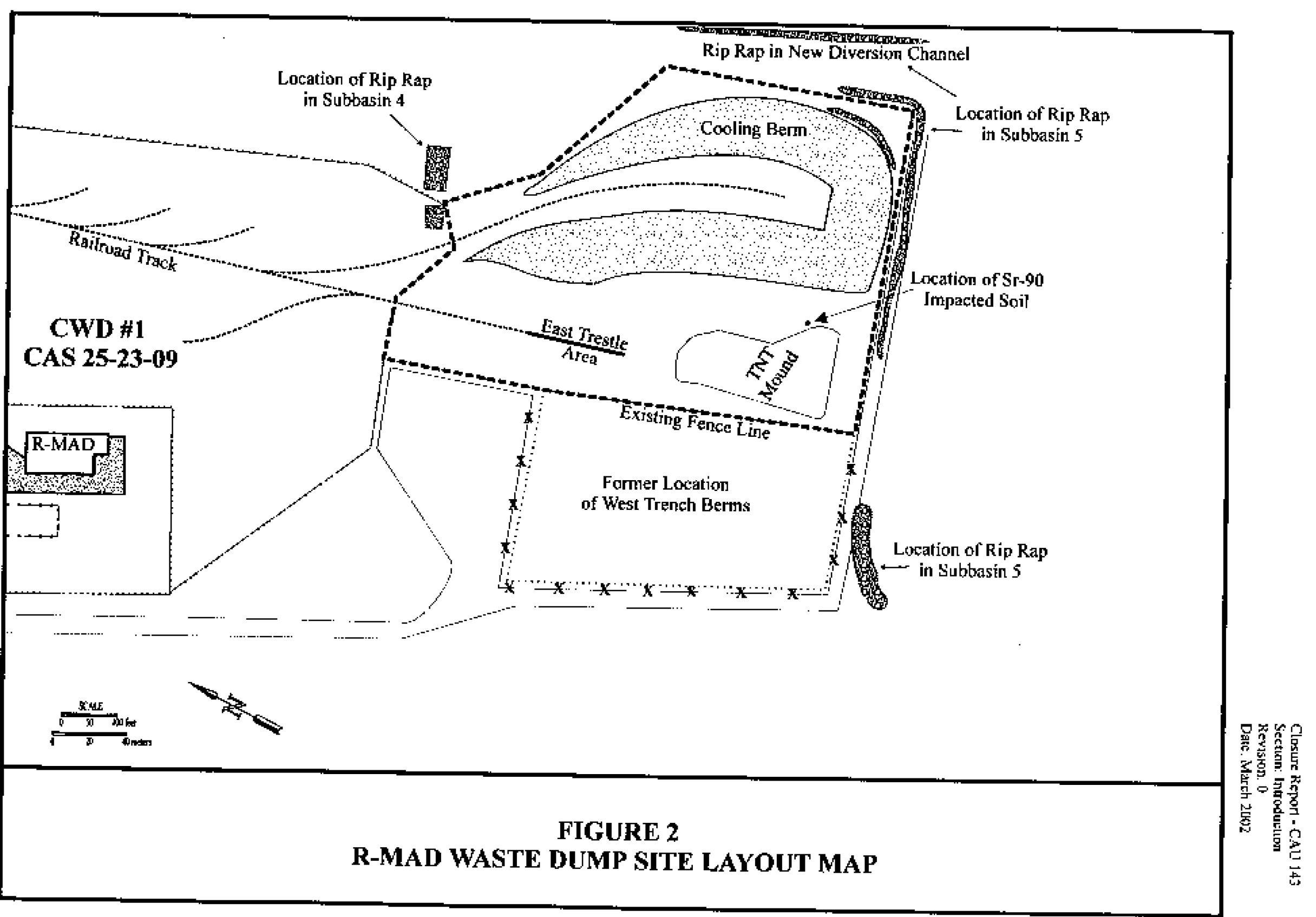




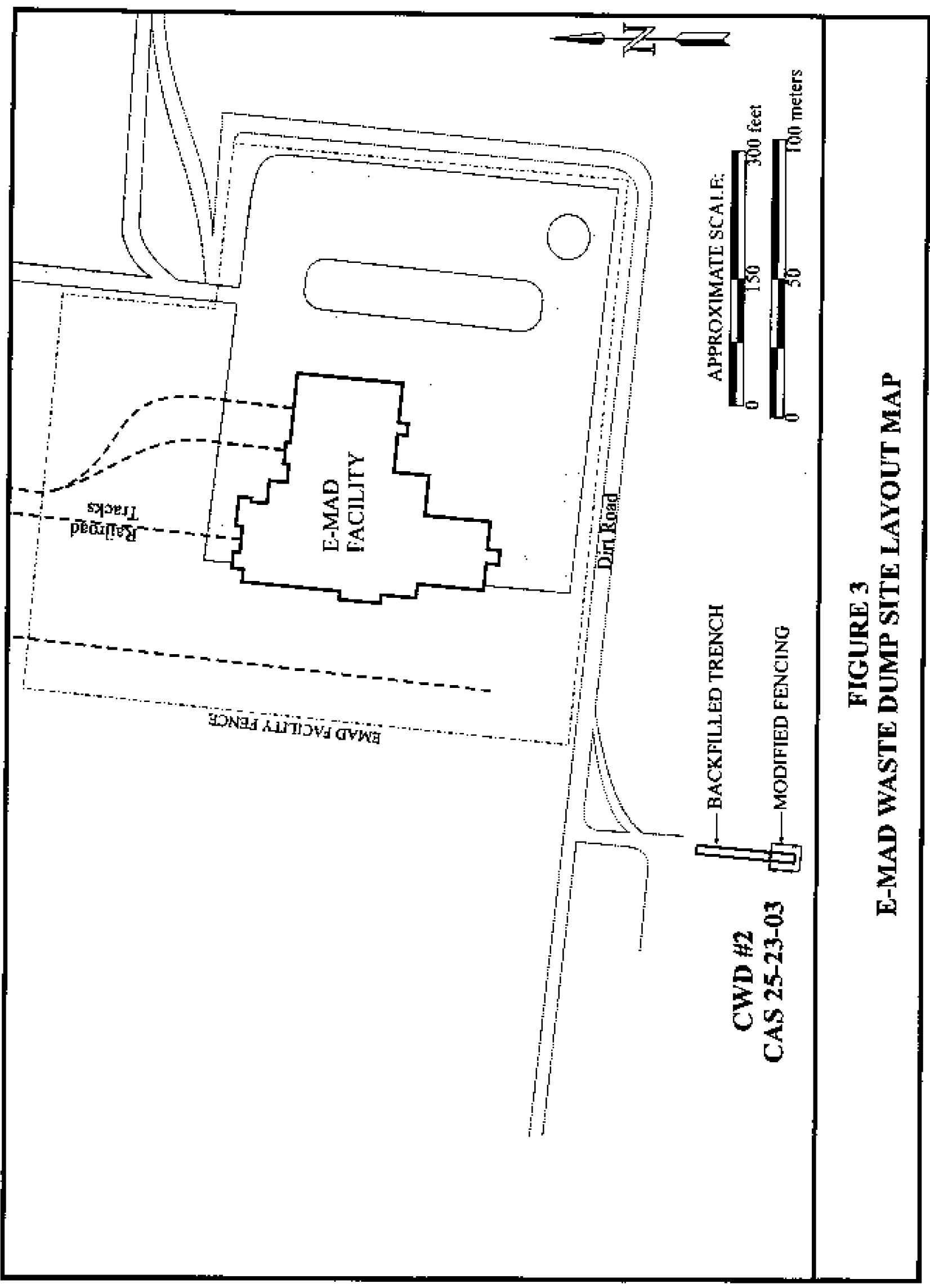


- Earthwork at the West Trenches consisted of placing additional clear cover material ower the trenches, regrading the area to its natural slope, and mitigating the potential for channelized erosion at the south end of the West Trench near the fence line.

- The existing signage and fencing in the vicinity of the R-MAD West Trenches were left intact. New signs and postings were set up along the R-MAD cast track and near the cooling berm.

- The cooling berms around the R-MAD East Track were icft in place.

E-MAD

- The E-MAD Trench (CWD +2 ) was backfilled with clean soil from the mound adjacent to the open trench. The trench was backfilled to an elevation slightly greater than existing grade.

- A diversion berr was established around the trench to diver potential storm water runon/runoff potential.

- Signage and fencing were modified to include only the currently filled portion of the trench.

\subsection{CLOSURE REPORT CONTENTS}

This CR is divided into the following sections:

Section 1.0 - Introduetion

Section 2.0 - Closure Activities

Section 3.0 - Waste Disposition

Section 4.9 - Closure Verification

Section $\$ .0$ - Conclusions and Recommendations

Scclion 6.0 - References

The appendices of this document have been modified from the approved July 2001 FFACO outline. The following FFACO outline appendices have either not been included or revised as indicated below:

- Data Quality Objectives (DQO) as developed in the CADD (DOE/NV, 2000a). DQOs were not developed for closure of the Area $25 \mathrm{CWDs}$. The earthwork was porformed to the criteria specified in the CAP (DOENN, 2001).

- Closure Certification is not required. Closure verification and subsequent annual inspections are necessary for fulfilling closure requirements.

- Appendix A, "As-Built" Drawings and Engineering Calculations for CAU 143. 
- Appendix B, Confirmation Sampling Test Results (e.g, analytical reports for leadimpacted soil verification samples and $\mathbf{S T}-90$ impacted soil verification samples).

- Waste Disposition Documentalion is pending for four 208-liter [L] (55-gallon [gal]) drums of Sr-90 impacted soil and will be provided in the first Post-Closure Monitoring report.

The following documents were used to develop this CR:

- Corrective Action Investigation Plan for Cortective Action Unit 143: ATea 25 Contaminated Waste Dumps, Nevada Test Site, Nevada, Rev, 1, DOENVV-506 (DOE NV, 1999).

- Corrective Action Decision Document for Corrective Action Unit 143: Atea 25 Contaminated Waste Dumps, Nevada Test Site, Nevada Rev. 0, DOE NV-617 (DOENV, 2000a).

- Contective Action Plar for Corrective Action Unit 143: Area 25 Contaminated Waste Dumps, Nevada Test Site, Nevada, Rev. 0, DOE/NV--698 (DOENVV, 2001).

No DQOS were deweloped for the closure activitjes for CAU 143. The earthwork activities were controlied by adherence to the design engineering specifications developed for the CAP (DOE $/ \mathrm{NV}, 2001$ ). Verfication of the design is documented in the construction "as-built" drawings incladed in Appendix A of this document. 


\subsection{CLOSURE ACTIVITIES}

This section of the CR details the specific activities involved in the closure of CAU 143.

\section{2,1 DESCRIPTION OF CORRECTIVE ACTION ACTIVITIES}

Closure of CAU 143 was completed using the approved Comective Action Plan for Corrective Action Unjt 143: Area 25 Contaminated Waste Dumps, Nevada Test Site Nevada, Revision 0 , (DOE NV, 2001). The CAP was based on the recommendations in the Corrective Action Decision Docurient for Corroctive Action Unit 143: Area 25 Contaminated Wastc Dumps, Novada Test Site, Nerada (DOENV, 2000a). Prior to begining closure activities, the following pre-field activities were completed:

- Preparation o[ National Environmental Policy Act documentation (checklist).

- Preparation of the Field Management Plan For Corrective Action Lnit 143 : Area 25 Contaminated Waste Dumps, Nevada Test Site, Nevada, (Bechtel Nevada [BN], 2001a)

- Preparation of the Sile-Specife Health and Safety Plan for Closure Activities at Corrective Action Unit 143: Area 25 Contarninated Waste Dumps, (BN, 200lb).

- Preparation of the DOENV Real Estate/Operations Pemoit.

The following is the scope of the closure actions implemented for CAL 143. Construction activities consisted primarily of earth moving. Figure 4 shows an aerial view of the R-MAD CWD area before the start of remediation activities.

\subsubsection{Remoral of Sr-90 Impacted Soil}

Site characterization, perfomed by Intemational Technology Corporation in 1999, revealed a surface soil sample at the R-MAD waste dump location that contained Sr-90 above the action level of 3 picoCuries per gram (pCi/gr) (DOE/NV, 2000a). The Sr-90 impacted soil area was located within the East Trestle area fence, directly southeast of the TNT Mound (Figure 2). Approximately 1 cubic meter $\left(\mathrm{m}^{3}\right)\left(1.3\right.$ cubie yards [yd $\left.\left.{ }^{3}\right]\right)$ of Sr-90 impacted soil was removed and placed into four $208-\mathrm{L}(55$-gal) drums. The Sr- 90 impacted soil removal activities were conducted between November 7, 2001 and November 14,2001.

A site-specific Cesium (Cs)-137/Sr-90 ratio was not established at CAU 143 because this ratio has been previously established for other Nuclear Rocket Development Station sites. The ratio of $\mathrm{Cs}-137$ to $\mathrm{Sr}-90$ is expected to be 1 to 1 . Therefore, detectable levels of $\mathrm{Cs}-137$ indicate that elevated levels of Sr-90 are present. Because Cs-137 emits gamma ionizing radiation, field screening instruments can be used to establish the presence of Sr-90 based on the known Cs-137 and $\mathrm{St}-90$ ratio. 


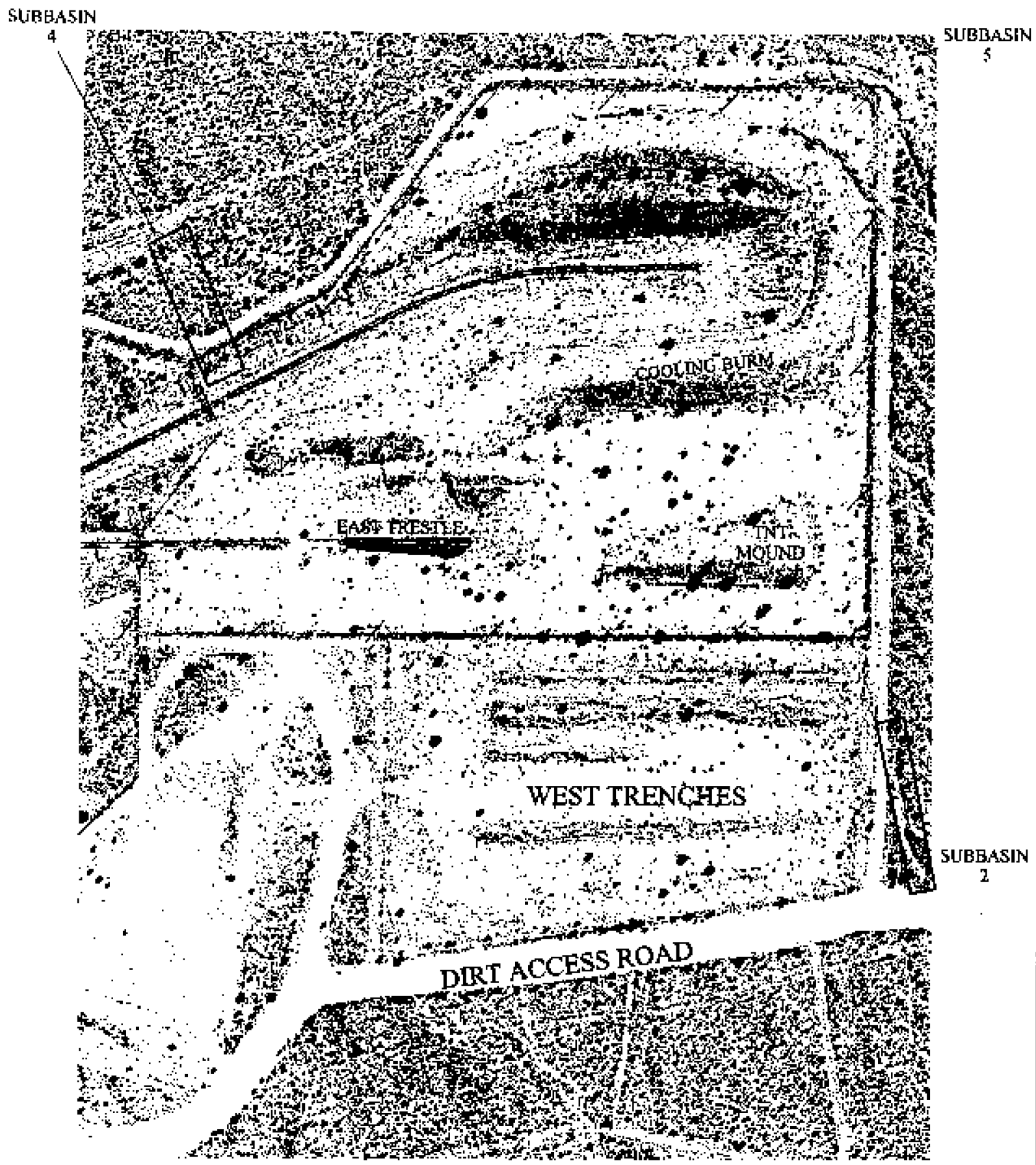

FIGURE 4 R-MAD AERIAL PHOTOGRAPH BEFORE REMEDIAL ACTION 
The project heat th physicist developed a field screening protocol to be used during the excavation to assess the progress in removal of the $\$+-90$ impacted surlace soil area. An Radiological Control Technician (RCT) used a Field Instrument to Detect Low-Energy Radiation (FIDLER) instrument to survey the excavation area for the presence of Cs-137. This instrument had sufficient sensilivity for the $\mathrm{Cs}-137$ to determine whon near normal background levels were achieved. The background level for this instrument was approximately 130 counts per second (cps).

The initial gamma aclivity levels of inpacted soil were measured with the FIDLER between a range of 300-400 cps within the general excavation area and higher gamma activity was mcasured in localized areas of the excavation. The averase actizity levels gradually decreased as the excavation progressed until they were approximately $120 \mathrm{cps}$ and within the acceptable range of background. The Sr-90 impacted soil was removed from the excavation and placed in four 208 I (55 gal) drams.

A set of verification samples was collected at the bottom of the inpacted soil excaration area. A total of five verification samples were collected from the base of the Sr-90 excavation. Four soil samples were collected from the corner of each sidewall and one sample from the center of the excavation. In addition, two quality assurance/quality control samples (I duplicate and 1 equipment blank were collected. The sampling activitics were recorded in a field logbook which included the following information: (a) dates and times of sampling activities; (b) names of sampling personnel; (c) location of sampling noting the sample identification number; and (d) the wolume, weight, and description of the sample taken. A pre-screened analysis of the verification samples was performed at R-MAD using a In Situ Object Counting System. The samples were cooled to approximately 4 degrees Celsius ( $C$ ) and transported to BN Environmental Technical Services under strict chain-of-custody procedures for a formal laboratory analysis.

Analytical results for the verification samples were received on December 19, 2001. The results showed no radiological constituents above background levels, $3 \mathrm{pCl} / \mathrm{gr}$ (DOE/NV, 2000a). The Sr-90 impacted soil excavation area was backFiled on January 14,2002, with clean [il] from the area of excatation. Analytical tesults for the verification samples are presented in Appendix $B$. Radiological survey results of the Sr-90 impacted soil area and surpounding areas are prosented jn Appendix D.

\subsubsection{Level the R-MAD West Trench Berms to the Existing Grade}

The West Trench berm field activities were conducled between November 5, 2001 and December 4, 2001 .

Earthwork at the West Trench Berms consisted of removing the top clean layer of soil from six trench berms, using the soil as backfill material at the East Trestle depression area, and regrading the West Trench area to its natural stope. In addition, channelized erosion at the south end of the West Trench Berms was mitigated by diverting the natural drainage flow to the southwest. 
A sctaper and front-end loader were used to remove the top clean layer of soil from the West Trench berms. A water truck was also used for dust suppression. The extent of lateral and vertical radiological subsurface contamination in the berms ranged from 2.2 meters ( $m$ ) ( 7 feet [f] ) wide to $138 \mathrm{~m}$ ( $450 \mathrm{f}$ ) long to $3.1 \mathrm{~m}$ (10 ft) in depth. Approximately $130 \mathrm{~m}^{3}$ (800 yd) of backfill material was removed from the top layer of the West Trench bems. Radiological surveys of the West Trench bem area were perfomed after the lop layer of soil was ronowed to verify that the remaining soil was not impacted. A goldak melrotech survey and geophysical survey were conducted within the west Irench betm area. The surwey detecled traces of mela] debris 15 to 30 centimeters [cm] (6 to 12 inches [in]) below the surface. The detected areas of melal debris were marked and Global Positioning System (GPS) coordinates were taken to identify the marked areas after additional clean cover material was placed over the trenches during grading. GPS coordinate data were recorded in a field logbook and are provided in Appendix $\mathrm{C}$.

\section{Rusted Metal Frame Debris}

Three 1.2-m (4-ft) long connected sections and two separate sections of rusted frame metal were discovered by an operator during West Trench berm removal. The frames were covered with a layer of soil and nust when initially excavated. An RCT surveyed the exposed melal debris with an NE Electra survey instrument. The beta-gamma activity was slightly elevated ( $<500$ disintegralions per minute (dpm) above background), but was well below release limits as given in Table 2-2 of the NV/YMP Radiological Control Manual (DOE/NV, 2000b). Therefore, the excavation was allowed to continue. A front-end loader stockpiled the debris into an isolated area at the edge of the excavation. The metal debris was washed numerous times by the water truck used to support excavation. This removed much of the original soil and rust. The metal debris was later placed into a transportation lugger pending disposal. While performing final release surveys on the metal debtis in the lugger, elevated beta-ganma readings were observed. The project health physicist decided that the metal debris should be removed from the lugger so that each piece could be resurveyed. The RCTs performed integrated counts on each piece with detectable beta-gamma activity. All debris averaged less than the $5,000 \mathrm{dpm} / 100$ square centimeters $\left(\mathrm{cm}^{2}\right)$ total activity ailowed for free release (Table 2-2) (DOE/NV, 2000b). One metal piece had a $100 \mathrm{~cm}^{2}$ area of approximately $11,000 \mathrm{dpm}$. This spot was below the 15,000 dpm criteria allowed for free release (DOE $N$ V, 20000). All of the metal was returned to the lugger and released to the sanitary waste landfill in Area 23 for disposal.

\section{Radiological-Impacted Płpe}

A radiological-impacted pipe reading $150,000 \mathrm{dpm} / 100 \mathrm{~cm}^{2}$ was exposed at the surface by a front-end loader during West Trench bem removal. The radiological-inpacted pipe was wrapped with a nylon fabric material believed to be a form of asbestos. An Industrial Hygienist (IH) performed a visual inspection of the nylon fabric material and collected samples for laboratory analysis to determine if the malerial contained asbestos. The laboratory results for three subject samples collected were negative for asbestos.

In addition, the radiological-impacted pipe was attached to a larger network of piping enbedded approximately $0.6 \mathrm{~m}$ (2 ft) in the subșuface. The area sutrounding the radiological-impacted pipe was isolated and roped off with orange fencing to designate the discovery and allow remediation activities to continue within the West Trench berm area. After the top layers of the West Trench berms were removed and 90 percent of grading completed, the exposed rad- 
impacled pipe was compacted into the surface using a front-end loader. Compaction was the preferted altemative in lieu of pipe removal, primarily due to the potential risk associated with exposing a larger network of radiological-impacted pipe with unknown levels of radiosctivity. A 0.9-m (3-ft)-squarc section of the area was backfilled with $0.3 \mathrm{ml}$ ( $1 \mathrm{ft}$ ) of top soil. The surface compacted arca was graded to blend into the thatural drainage flow of the West Trench area. GPS coordinate data were recorded in a fjeld logbook and are provided in Appendix C.

\section{Six-Foot Drain Pipe}

A $1.8-m$ (6-ft)-high stainless steel drain pipe was exposed to the surface by a front-end louder during West Trench berm removal. The drain pipe was attached to other segments of pipe embedded in the subsurface. Radiological surveys were perfomed by an RC.T with an Electra instrument to determine if the exposed drain pipe or surrounding area was radiologically inpacted. The drain pipe also contained elbow joints that were soldered with a material that appeared to be lead-based. An industrial hygienist performed a survey for lead on the soldcred material within the elbow joints of the drain pipe. A Niton XL lead detector instrument was used and placed directly over the soldered joints of the pipe as well as two small pieces of the solder. The Niton detected no lead on the solder materiat within the clbow joints of the drain pipe. Therefore, the $1.8-\mathrm{m}$ (6-ft) drain pipc was severed using a hand saw at ground surface and placed into a transpottation lugger to be disposed of in the Area 23 sanitary waste landfill. GPS coordinate data were recorded in a field logbook and are provided in Appendix $C$.

\section{Seven-Foot Diameter, 0.5-Inch-Thick Drain Pipe}

An open-ended 2.1-m (7-ft)-diameter, 1.3 -cm (0.5-in)-thick drain pipe was exposed during West Trench renoval activities. The drain pipe was allached to a larger segment of pipe embedded in the subsurface. Radiological surveys were conducted by an RCT using an Electra and FDLER detector. No conlamination or elevated gamma activity was detected on the drain pipe or surrounding area. Approximately $15 \mathrm{~cm}$ (6 in) of soil was removed from around the drain pipe and a front-end loader was used to break the pipe at the ground surface. Additional radiologica] surveys were performed on the cut end of the drain pipe prior to placing the pipe into a transportation hgger for disposal in Area 23 as sanitary waste. GPS coordinate data were recorded in a field logbook and are provided in Appendix C.

\section{Former Hazardous Waste Accumulation Area}

Debris from a former hazardous waste accumulation area (HWAA) was discovered near the northwest comer of the West Trench area. The HWAA was used to support site characterization work in 1999. An RCT performed a survey of the genera! area to confint that the sectioned-off area was not impacted. Remnants of the pad included a black milar, seven pallets, and other niscellaneous debris. Upon receiving documentation to confirm the characterization activities within the area, the pad was cleaned up and the debris disposed of as sanitary waste.

\section{Grading of Site}

Final grading was completed in the West Trench bem area and leveled to existing grade using a the grader. The adjacent area outside of the West Trench front gate, near the East Trestle front gate, was also graded to blend into the natural drainage flow of the West Trench area.

\section{Fence Repair and Installation of Warning Signs/Postings}

To prevent indiscriminate access of unauthorized personnel to the graded West Trench area, a 
damaged fence was repaired. The fence was located along the southeast perimeter of the Wrost Trench area. Approximately $7.5 \mathrm{~m}$ (25 fl) of three-strand barb wire were allached betwecn live fence posts. The fence repair activities were conducted between November 20,2001 and November 21, 2001.

In addition, the access gate to the West Trench area was removed using a front-end loader to aliow better access for heavy equipment during remediation activities. After the completion of all remediation activities in the West Trench area, the front access gate was restored and proper signs were posted to maintain adequate administrative access controls.

A total of 17 Lndergtound Radioactive Material signs were posted on the existing fence. Five signs were posted north of the West Trench area, eight signs were posted on the west fence, and four signs were posted on the south fence. Also, the Wost Trench area will romain designated as a controlled area that requires general employee radiological training for access and entry.

\subsubsection{Backfill the R-MAD East Trestle Area}

The field activities for backfiling the East Trestle area were conducted between November 5 , 2001 and November 28, 2001. Specific construction details are provided below.

Earthwork at the East Trestle consisted of backfilling the large trestle depression area with backfill material fron the West Trench berms, the TNT Mound, and a borrow fill pit located northwest of the R-MAD facility. The East Trestle area dimensions were $18 \mathrm{~m}$ ( $60 \mathrm{ft}$ ) wide to $42 \mathrm{~m}$ ( $140 \mathrm{ft}$ ) long by $6 \mathrm{~m}$ (20 ft) in depth. Approxinately $5,040 \mathrm{~m}^{3}\left(6,400 \mathrm{yd}^{3}\right)$ of backfill material was distributed at an elevation slightly above the existing track grade to eliminate depressions, while the existing slopes were modified to minimize runoninumoff, infiltration, and possible erosion. In addition, the East Trestle track was backfilled to the north fence boundary with approximately $20 \mathrm{~cm}$ ( 8 in) of excess back fill material from the borrow fill pit.

\section{West Trench Berms}

Backfill material was retrieved from the West Trench berns by a front-end loader and scraper. A water truck was used to maintain dust suppression. Approximately $630 \mathrm{~m}^{3}$ ( $800 \mathrm{yd}$ ) of backfill material from the West Trench berms was used to backfill the East Treslle area.

\section{Camel Back}

A camel back was located on the teminus of the East Treslle railroad spur attached by two clamps. The camel back was used to tip the rail cars over as they unloaded solid radioactive waste material into the pit area underneath the trestle. The camel back location, weight, and the questionable integrity of the trestle structure created a safety concern for the initial method of removal. Therefore, after a reevaluation of altematives, a new strategy and approach was developed to facilitate camel back removal. A soil tamp was constructed with West Trench berm material to reach the 900 kilogram (kg) (2,000 pounds [lbs]) camel back. A front-end loader was used to collapse the camel back into the depression area. Subsequently, the trestle tracks, rails, and wooden column structures were demolished to serve as additional backfill for the open depression area. An 2.4- to 3-m (8- to 10-ft) layer of soil provided a protective cover over the 
camel back and adjoining structures.

\section{TNT Ylound}

The TNT Mound, consisting of approximately $3,150 \mathrm{~m}^{7}\left(4,000 \mathrm{yd}^{3}\right)$ of soil, was used as backfili material for the East Trestle area. The mound was located within the southwest corner of the CWD 1 i fenced area, east of R-MAD. Back Fill material was relriewed from the TNT with a seraper, D-9 dozer, and front-end loader. In addition, a water truck was used for dust suppression during soil removal activities.

\section{R-MAD Borrow Pit}

Excess backfill material from the R-MAD borrow pit was used to complete backfill activities in the East Trestle area. Approximately $1,260 \mathrm{~m}^{3}\left(1,600 \mathrm{yd}^{3}\right)$ of backfil materia) was retricked fron the borrow pit and transported to the trestle area by the scraper. A D-9 dozer wras used to load the soraper with borow fill matejal while the scraper transported a full $17-\mathrm{m}^{3}{ }^{3}$ (22-yd $\mathrm{d}^{3}$ ) load to the east trestle area. Traffic was monitored and controlled to allow free road access for the scraper during transportation to and from the borrow pit.

\section{Grading of the Site}

The Easi Trestle atea was completely backfilled with clean soil and leveled to existing grade with the grader. The front-end loader was used to minimize surface obstructions and prevent ponding.

\section{Fence Repair and Jnstallation of Warning Stgns/Postings}

The existing chain-link fencing remained in place to prevent access of unauthorized personnel into the East Trestle area. A set of new signs was posted in between the TNT Mound and cooling berm to identify elevated levels of radioaclive material within the area Five signs were posted as "Caution- Radioactive Material" within a $15-\mathrm{m}$ (50-ft) by $21-\mathrm{m}$ (70-ft) square area direclly south of the East Trestle. The front gate of the East Trestle area has five signs reading "Caution-Underground Radioactive Material" and six additional signs posted along the south end of the chain-link fence. Also, the East Trestle area will remain designated as a controlled area.

Founeen radioactive material postings have also been placed along the length of the cooling berm eastem railroad track.

\subsubsection{Erosion Protection Instatlation}

Erosion protection was necessary within three subbasin areas of the R-MAD CWD based upon a flood assessment and hydraulic analysis and evidence of past erosion. The erosion protection materials included a non-woven, needle-punched geotextile filter fabric, fine aggregate (sand), and rip-rap rock as the final cover. The volume, size, and distribution of erosion protection materials varied in accordance with the approved design specifications (DOE/NV, 2001). The method of installation required that an erosion channel grade be constructed to a specific depth and lined with a geotextile fabric, sand, and rip-rap rock. Approximately $15 \mathrm{~cm}(6 \mathrm{in})$ of fine aggregate (sand) was used as a secondary layer for placement of rip-rap rock on top of the fabric layer. Rip-rap rock was used as a final backfill media in the three subbasin areas to maintain control of the natural drainage flow. A grader, front-end loader, backhoe, forklift, and water 
truck were used to construet the subbasins.

\subsubsection{Subbasin 4}

Erosion protection was firgt installed ith the Subbasin 4 channelized erosion area. Subbasin 4 is located at the far northeast comer of the R-MAD CWD arca. Approximately $213 \mathrm{~m}^{3}$ (270 $\left.\mathrm{yd}^{3}\right)$ of rip-rap rock and $134 \mathrm{~m}^{3}\left(170 \mathrm{yd}^{3}\right)$ of fine aggregate were deliwered to Subbasin 4 for erosion protection. The erosion channel at Subbasit 4 was excavated to a $3: 1$ slope depth of $0.9 \mathrm{~m}$ ( $3 \mathrm{ft}$ ) and a width of $9 \mathrm{~m}$ ( $30 \mathrm{ft}$ ). A rip-rap rock thichness of $0.3 \mathrm{~m}$ (1 ft) with a $15-\mathrm{cm}$ (6-in) fine aggregale cushion was required for Subbasin 4 . Erosion prolection activities for Subbasin 4 were conducted between December 5, 2001 and December 12, 2001.

\subsubsection{Subbasin 2}

Erosion control was established in Subbasin 2 to mitigate channelized erosion. Subbasin 2 is located near the far southwest corner of the R-MAD CWD area. The erosion channel at Subbasin 2 was excavated to a $3:$ I slope depth of $0.6 \mathrm{~m}(2 \mathrm{ft})$ and a width of $3.6 \mathrm{~m}$ (12 ft). A riprap rock thickness of $15 \mathrm{~cm}$ ( 6 in) with a $15-\mathrm{cm}$ (6-in) sand cushion was the required erosion control specifications for Subbasin 2. Installation of etosion protection for Subbasin 2 occurred between December 13,2001 and December 19,2001. A wo-strand yellow wire rope fence was installed around the Subbasin 2 rip-rap area.

Excess rip-rap from Subbasin 2 was used to mitigate other areas of erosion and support radiological control. A front-end loader placed a 77-m (250-ft) linear pile of small nip-rap rock along the exterior south perimeter of chain-link fence to mitigate potential runon between Subbasin 5 and the East Trestle area.

\subsubsection{Subbasin 5}

The last and largest erosion area requiring long-term protection was Subbasin 5 . Subbasin 5 is located at the far southeast comer of the R-MAD CWD area. Approximately $842 \mathrm{~m}^{3}\left(1,070 \mathrm{yd} \mathrm{d}^{3}\right)$ of rip-rap rock and $425 \mathrm{~m}^{3}\left(540 \mathrm{yd}^{3}\right.$ ) of fine aggregate wore delivered to Subbasin 5 for erosion protection. However, a change in the erosion control design for Subbasin 5 was implemented to utilize an existing drainage channel to divert stom water flow away from the CAU site boundary. The existing drainage channel was repaired and extended $138 \mathrm{~m}(450 \mathrm{f})$ to provide long-term erosion protection during periods of high precipitation. The engineer-designed diversion channel at Subbasin 5 was excavated to a $3: 1$ slope depth of $0.9 \mathrm{~m}(3 \mathrm{ft})$, at a flat bottom channel width of $10 \mathrm{~m}$ (20 fi). A backhoe was used to position rip-rap along the diwersion channel and supported snall excavation in the adjacent erosion channel near the cooling berm. The front-end loader was used to construct the diversion channel and transported aggregate and rip-rap material from the stockpile area to existing erosion areas. A grader was used for road maintenance and access to Subbasin 5 . The water truck was used to maintain dust suppression and provide compaction for the diversion channel. The diversion channel compaction was accomplished wetting the channel and driving the water truck three times across the top of the berm for stabilization. Erosion protection activities for Subbasin 5 were conducted 
Approximately $54 \mathrm{~m}$ (180 ft) of chaitr-link fencing was removed to support erosion protection activities at Subbasin 5. The chain-link fence was restored after $118 \mathrm{~m}^{3}$ ( 150 yd ${ }^{3}$ ) of rip-rap rock was placed in a $0.75 \mathrm{~m}$ (2.5-ft) deep erosion channel botween January 10,2002 and January 23 , 2002. Eighteen galvanized stecl fence posts were driven into the ground at a $3-\mathrm{m}(10$-ft) linear distance from each post. The chain-link fence was completed on January 24, 2002, to maintain site-access control with the Subbasin 5 area.

Excess rip-rap rock for Subbasin 5 was placed along the west embankment of the $135 \mathrm{~m}$ (450 ft) extended diversion channel at a 4.5-m (15-ft) width from the top of the berm to surface grade. The excess rip-rap rock was used to reinforce drainage flow control in case an overflow condition affects the diversion charnel. Additional excess rip-rap for CAU 143 has been stockpiled near Subbasin 5 for future use.

\subsubsection{Removal and Disposal of Metallic Lead}

A lead-impacted soil area was discovered during a topographic survey walk-down for the construction of an engineer-designed diversion channel. The lead-impacted soil area was at the southeast comer of the R-MAD CWD near Subbasin 5. A Nion XL lead detector was used to confirm the presence of lead. An exposure assessment was conducted during remediation activities which consisted of the following:

- The IH monitored the workers for airborne lead dust exposure with a breathing zone air (BZA) monitoring device during lead-impacted soil removal. The BZA sample results for aibone lead were below the Occupational Safety and Health Administration (OSHA, 1999) lead standard of 50 micrograms per cubic meter and further reduced by virtue of the workers' use of full-face respirators with high-efficiency particulate air filtration.

- The $\mathrm{IH}$ conducted swipe samples of the construction equipment for lead contamination during excavation of the lead-impacted soil. The construction equipment supporting lead removal was the backhoe, front-end loader, and a $9,090-\mathrm{kg}$ (10-ton) forklift. In addition, the water truck was used to maintain dust suppression and minimize the generation of airbome lead particles. Swipe samples were taken prior to and after use of the equipment A total of 28 swipe samples were taken, 14 prior to operations and 14 following operations. The Niton XL lead detector was used to detect lead particulates on the swipes. After the completion of lead-impacted soil removal, all 28 swipe samples were negative for lead.

Lead-impacted soil removal activities were conducted between January 8, 2002 and January 9, 2002. A backhoe was used for the excavation while a fronl-end loader transpotted the impacted soil to one of four roll-off containers located approximately $21 \mathrm{~m}$ ( $70 \mathrm{ft}$ ) from the point of excavation. Limited access due to stockpiled rip-rap and aggregate prevented the roll-off containers from being located closer to the excavation area. The non-recyclable lead was located in a $6-\mathrm{m}(20-\mathrm{ft})$ by $9-\mathrm{m}(30-\mathrm{ft})$ square area to a depth of $0.3 \mathrm{~m}$ ( $1 \mathrm{ft})$. Approximately $32 \mathrm{~m}^{3}$ 
( $\left.40 \mathrm{yd}^{3}\right)$ of lead-impacted soil was excarated and placed directly into roll-off containers. Following removal of the lead-impacted soil, a series of field screening samples were taken. $A$ totak of 19 field sorening samples were taken within a $15-\mathrm{cm}(6-\mathrm{in})$ and $0.3-\mathrm{m}$ (1-ft) depth of the excavation area. Results or the field screning confirmed that all lead-impacted soil was removed. Six soil verification samples were then collected and submitted for total lead analysis (Figure 7). The clean-up level used for lead removal was the U.S. Environmental Protection Agency (EPA) Region IX Preliminary Remediation Goal (PRG) of 750 milligrams per kilogram for lead in industrial soils (EPA, 1996). A HWAA was established for the roll-off containers while awaiting analytical results.

The six verification samples were collected from the highest probable lead-impacted areas. The sample locations were selected based upon the distribution of lead in the soil, results from previous walk-through surveys using the Niton XL detector, and process knowledge of contaminated soil areas. Detailed analytical results data for the lead-impacted soil are presented in Appendix B.

BN Waste Management coordinated the disposal of all lead-impacted soil removed from CAU 143 with an approved off-site vendor. The lead-impacted soil containers were transported to a hazardous waste landfill in Grassy, Utah, for disposal. Copies of the waste manifests are included in Appendix F of this report.

\subsubsection{Backfill the E-MAD Trench}

The field activities were conducted at E-MAD betweer Nowember 28, 2001 and December 4, 2001. Specific construetion details are provided below.

Earthwork at the E-MAD Trench consisted of placing an additional $1,575 \mathrm{~m}^{3}\left(2,000 \mathrm{yd}^{3}\right)$ of clean soil cover material into the trench, constructing a diversion benm, general site grading, and modifying existing signs and fencing to include only the backfilled portion of the trench (Figure 5).

The E-MAD Trench measured approximately $4.5 \mathrm{~m}$ ( $15 \mathrm{ft}$ ) wide by $18 \mathrm{~m}$ ( $60 \mathrm{ft}$ ) long by $4.5 \mathrm{~m}$ (15 ft) in depth. The existing open trench was backfilled with clean soil from the mound adjacent to and south end of the trench.

\section{Diversion Berm}

A $0.3-\mathrm{m}$ ( 1 -ft)-high $0.75 \mathrm{~m}$ ( $2.5 \mathrm{ft}$ ) wide secondary diversion berm was installed at the E-MAD Trench in order to divert storm water runon.

\section{Fence Repair and Installation of Warning Signs/Postings}

A fence was installed to prevent unauthorized access to the backfilled sections of the trenches. Site access information and identification signs were installed on the fencing to meet hazard notification requirenents. The existing fence at the E-MAD Trench was modified to include a separate enclosure for only the filled portion of the trench that contains legacy waste. A two 


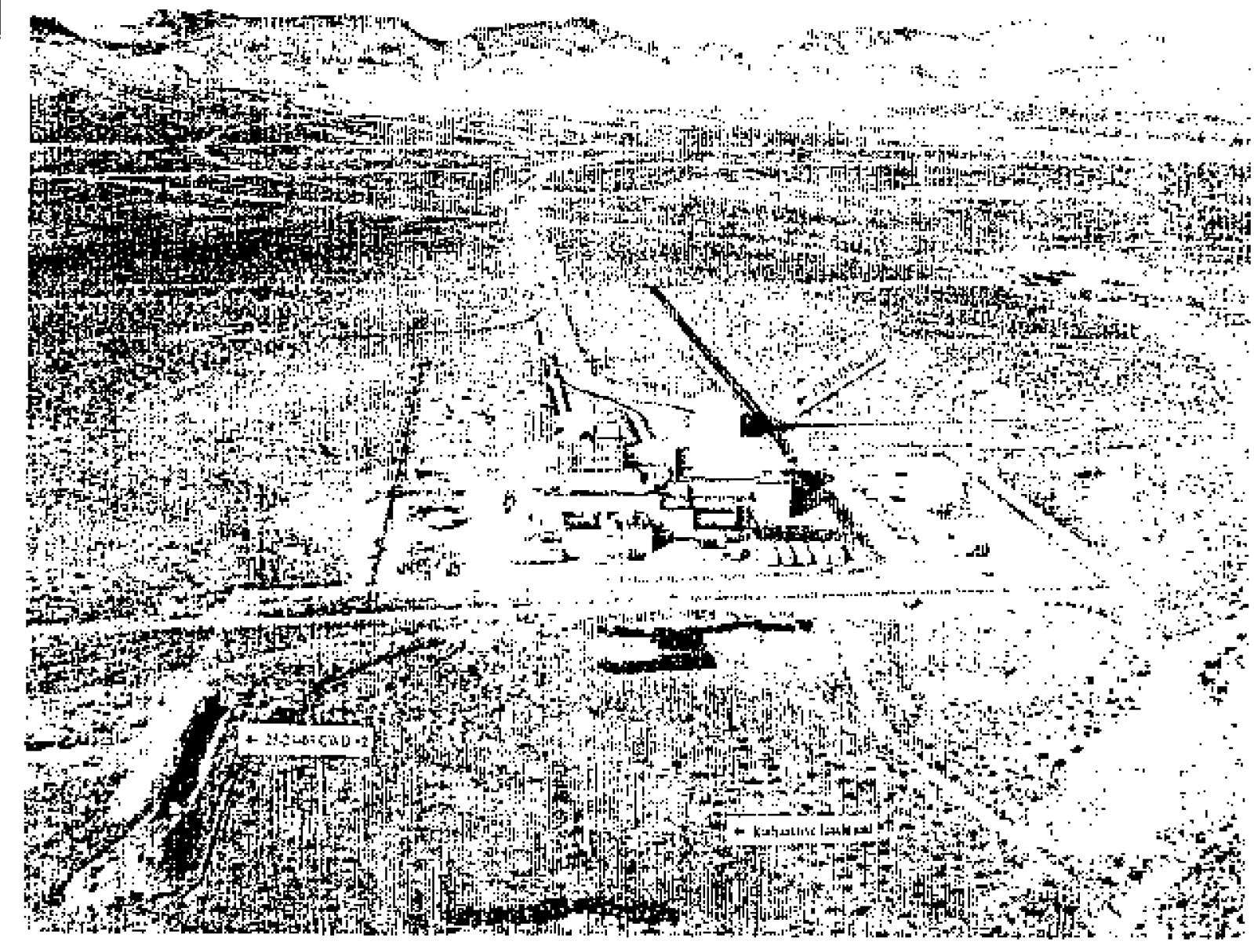

Souree: EG\&G Photograpn Nunber 6911-19-41 takan ir 1968 (EGsG, 1968)

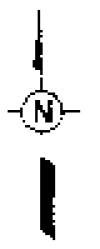

FIGURE 5

E-MAD AERLAL PHOTOGRAPH BEFORE REMEDIAL ACTION 
strand barbed wire and tee post fence mas constructed around this area on December 4, 2001 . The fence was posted as "Caution-Underground Radioactive Material" area.

\subsubsection{Demobilization}

All equjprent, labor, and excess materials supporting CAU I43 were demobilized by January 28,2002 . CAL 143 closure activities wartanted no decontamination of heavy equipment.

\subsection{DEVIATIONS FROM CAP AS APPROVED}

One Record of Technical Change (ROTC) was requested and approved during CAU 143 closure activities. The ROTC identified a change in the erosion control design for Subbasin 5 to utilize an existing drainage channel to divert stom water flow away from the CAU site boundary. The existing drainage channel was repaired and extended to provide long-tenm erosion protection during periods of high precipitation. Revisions to the original design engineering specifications and drawings are reflected in the final "as-built" drawings found in Appendix A of this report.

During CAU 143 closure activities at the R-MAD CWD Subbasin 5 area, approximately $32 \mathrm{~m}^{3}$ (40 $\mathrm{yd}^{3}$ ) of a Resource Conservation Recovery Act hazardous lead-impacted soil area was discovered in the path of a design engineer recommended diversion channel. Although the leadimpacted soil area was outside the scope of CAU 143 closure aclivities, it was remediated as a best management practice. Refer back to Section 2.1.5 for a brief description of the lead. impacted soil removal and disposal activities.

\section{2,3 CAU 143 CLOSURE ACTIVITIES SCHEDULE}

The completed closure field activities schedule is presented in Figute 6.

\subsection{CAU 143 FINAL SURVEY" "AS-BULL" DRAWINGS}

The final engineering "as-built" drawings for the CAL 143 Area 25 CWD are provided in Appendix A. 


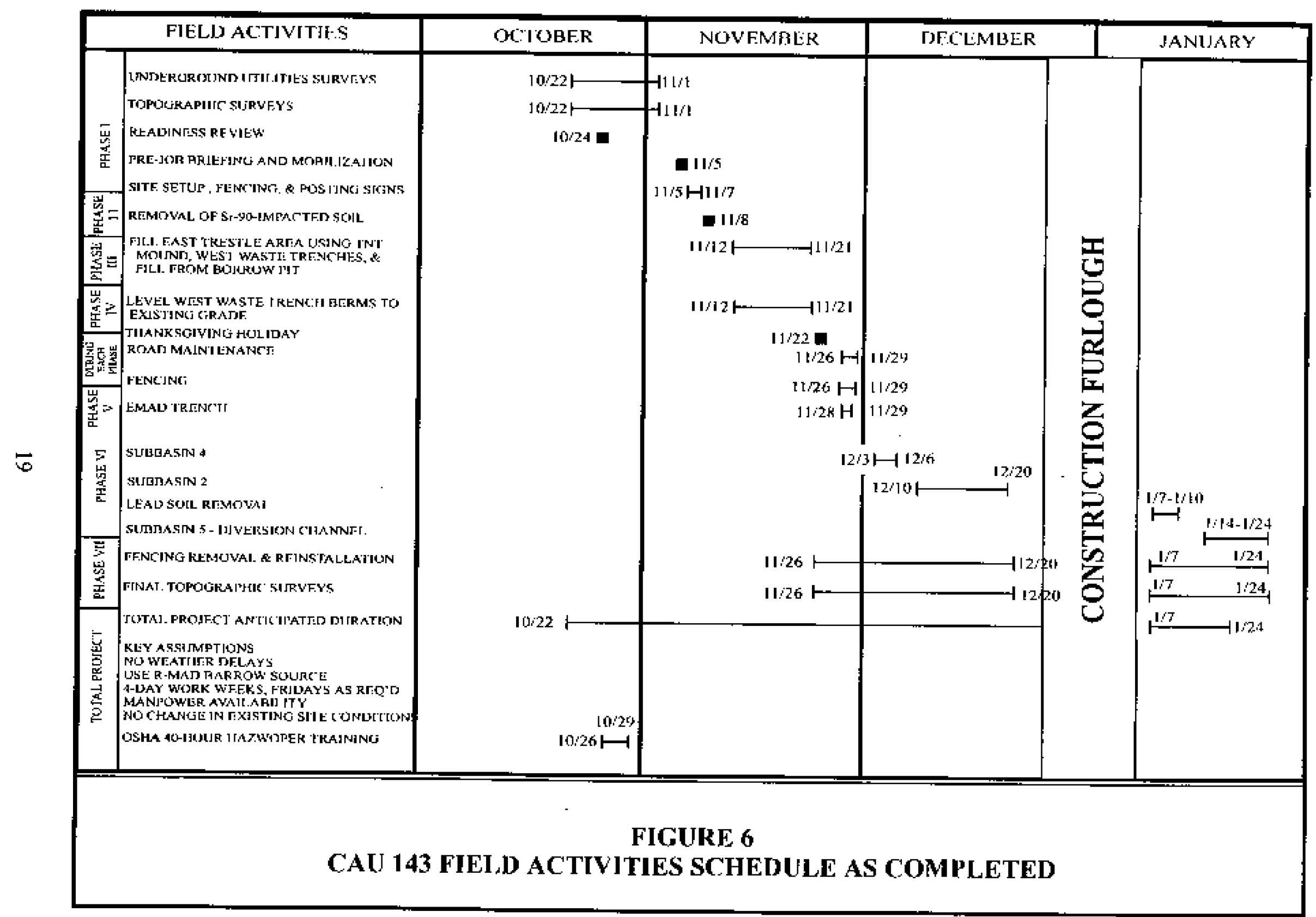


Cluswre Repmer - CAL1 i 43 Secton: Curture Aerithis's

Revisign. 0

[iate: Atarch 3003

THIS PAGE INTENTIONALLY LEFT BLANK 


\subsection{WASTE DISPOSITION}

Waste gencrated from CAL 143 closwe activities included radiologically impacted soil and particles, hazardous impacted soil, and nonhazardous waste gencraled from routine and nuiscellaneous clean-up activities. All waste was surveyed and managed in accordance with state and federal regulations, U.S. Department of Energy orders, and BN procedures. Sone waste forms required sampling to determine the appropriate waste disposition. All wasle was containcrized for proper disposal in the appropriate disposal landfill.

\subsection{RADIOACTIVE WASTE (LOW-LEVEL WASTE)}

Excawation of the $5 \mathrm{r}-90$ impacted soil atrea generated $1 \mathrm{~m}^{3}(1.3 \mathrm{yd})$ of low-level radioactivo waste (LLW) for disposal. The LLW is currently awaiting waste profile approwal from the Radioactive Waste Acceptance Program (RWAP). Pending RWAP approval, the Sr-90 impacted soil witl be disposed of as LLW at the Radioactive Waste Management Site in Area 5. Currently, the four 208-L (55-gal) waste contajners are temporarily stored in a designated container storage area within the R-MAD East Trestle area fence.

While conducting surreys in support of excavation activities within the R-MAD CWD site, the RCTs repotted that numerous areas had elevated gamma readings using the FIDLER instrument or beta-gamma readings using the NE Electra survey instrument. The source of the aclivity appeared to be extremely snall radioactive particles (carbonized fleck particles) dispersed at or just under the soil surface. The RCTs conducted systematic scan surveys over the entire R-MAD CWD site to detemine the size of the areas where these surface-deposiled radioactive paricles were concentrated. The perimeter of these areas were later posted with Radioactive Material signs to meet 10 Code of Federa] Regulation 835 gujdelines (OSHA, 1999). The areas were within the fenced compound that retained the Underground Radioactive Material postings. The first particle, discovered along the eastern railroad spur inside the cooling bem, measured $2.5 \mathrm{~cm}$. (I in) in length and $1.3 \mathrm{~cm}(0.5 \mathrm{in})$ wide. It weighed 5.5 grams $(0.01 \mathrm{lb})$. The open and closed shield readings with an RO-20 instrument were 250 and 10 millirem per hour (mRhr) at contact, respectively. The instrument readings were 10 and $0.4 \mathrm{mR} / \mathrm{hr}$ at $30 \mathrm{~cm}$ (12 in), respectively. The particle was placed in a plastic bag and secured inside a small shipping pig. The pig was secured with a security seal and placed inside a Sealand container at the R-MAD radicacive malerial storage compound. The second discovery infolved five smaller particles at the far southwest comer of the R-MAD East Trestle arca with an estimated cumulative weight of less than I gram (0.002 lb). The open and closed shield readings with an RO-20 instrument were 500 and $8 \mathrm{mR} / \mathrm{hr}$ at contact, respectively. The instrument readings were 4 and $60.2 \mathrm{mR} / \mathrm{hr}$ at $30 \mathrm{~cm}$ (12 in), respectively. The particles were also placed in a plastic bag and secured inside a small shipping pig. The pig was secured with a security seal and placed inside a Sea-land container at the $\mathrm{R}-\mathrm{MAD}$ radioactive material storage compound.

Detailed radiological survey data and reports are presented in Appendix D. 


\subsection{HAZARDOUS WASTE}

A lead-impacted soil arca was discovered during a topographic survey walk-through on top of a berm where an engineer-designed diversion channel was to be constructed. The melted/processed, non-recyclabie metal was localed in a 6-m $(20-\mathrm{ft})$ by 9 -m (30-ft) square area at a depth or $0.3 \mathrm{~m}$ (1 ft). Approximately $32 \mathrm{~m}^{3}$ (40 $\mathrm{yd}$ ) of lead-impacted soil was excavated ard placed directly into roll-off containers. All lead-impacted soil was removed and disposed or in three roll-off containers. A approximate $104,890 \mathrm{~kg}(231,243 \mathrm{lbs})$ of impacted soil was shipped off site to a permitted hazardous waste landfill in Grassy, Utah, for disposal. Waste disposal documentation is included in Appendix $F$ of this report.

\subsection{NONHAZARDOUS WASTE}

Nonhazardous waste, such as sanitary trash, personal protective equipment, metal debris, and miscellaneous construction debris was disposed of in the sanitary waste landfill in Area 23. Waste disposal documentation is included in Appendix $F$ of this report. 


\subsection{CLOSURE VERIFICATION}

Site closure was verified by:

- The removal of the St-90 impacted soil located near the TNT Mound in the R-MAD East Trestle area was confirmed by collecting and andyzing six verification soil samples (Tablo 1 and Appendix B). Figure 7 shows the locations of the verification samples. Verification samples showed that remaining soil was below background levels for Sr-90.

- The removal of the lead-impacted soilmaterial was cothlinned by visutil inspection of the area and, collecting and analyzing six verification soil samples (Table 2 and Appendix B). Figure 7 shows the locations of the verification samples. Verification samples showed that remaining soil was below the EPA Region IX PRG for lead in industrial soils (EPA, 1996).

- Site backfilling, regrading, and construction of erosion control structures as designed were verified by site "as-bujlt" drawings (Appendix A).

Criterion for verification sampling, backfilling, grading, erosion protection, and design engineering specifications and drawings were provided in the approved CAP (DOENV, 2001). The engineering "as-built" drawings included in Appendix A of this report verify that CAU J43 has been closed as specified in the CAP (DOENN, 2000b).

\subsection{DATA QUALITY ASSESSMENT}

The closure of Area 25 CWDs did not require the development of DQOs. The carthwork was perforned to the eriteria specified in the CAP (DOE/NV, 2001).

\subsection{USE RESTRICTIONS}

The Area 25 CWDs have been closed in accordance with the approved CAP (DOENNV, 2001). These CWDs have been fenced and posted with the proper waming signs reading "CautionUnderground Radioactive Material" or in specific areas "Radionetive Material". The future use of any land related to the Area 25 CWDs is restricted from any activity that may alter or modify the containment control as approved by the state of Nevada and identified in this document or any other CAU 143 documentation uniess appropriate concurrence from the NDEP is obtained in advance.

The specific location and post-closure monitoring requirements for the Area 25 CWDs were recorded on the CAU Use Restriction Information Form. The information on the completed form was added into the NNSA/NV Facility Infomation Management System and the Centra] Data Repository. The original CAU Use Restriction Fom was filed within the Area 25 CWD project file. A copy of the CAU use restriction information is included in Appendix $E$ of this report. 
TABLE I - RADIOANALYTICAL RESLLTS FOR CONFIRMATION SOIL SAMPLES

\begin{tabular}{|c|c|c|}
\hline $\begin{array}{c}\text { SAMIPLE } \\
\text { IDENTIFICATION }\end{array}$ & SAMPLE DATE & $\begin{array}{l}\text { STRONTIUM-90 } \\
(\mathrm{pCi} / \mathrm{g})^{\prime}\end{array}$ \\
\hline \multicolumn{3}{|c|}{ Strontium-90 action level established in CAU $143 \mathrm{CADD}$ (DOENV, 2000a) = 3 pCi:g } \\
\hline CWD $-\mathrm{S}-1$ & $11 / 14 / 2001$ & $\angle \mathrm{MDA}^{x}$ \\
\hline CWD-S-1 (Duplicate) $)^{\mathrm{d}}$ & $11 / 14 / 2001$ & 0.533 \\
\hline CWD-S-2 & $11 / 14 / 2001$ & $<\mathrm{MDS}$ \\
\hline CWD-S-3 & $11 / 14 / 2001$ & 0.312 \\
\hline CWD-S-4 & $11 / 14 / 2001$ & 0.162 \\
\hline $\mathrm{CWD}-\mathrm{S}-5$ & $11 / 14 / 2001$ & $\angle \mathrm{MDA}$ \\
\hline CHDLS.6 & $11 / 140001$ & 0.120 \\
\hline
\end{tabular}

Noles:

${ }^{2} \mathrm{pCi} / \mathrm{g}=$ picoCuries per gram

${ }^{\mathrm{b}} \mathrm{CWD}=$ Contaminated Waste Dump

${ }^{\mathrm{MDA}}=$ Minimum Detectable Actirity. See Appendix B for MDA values and sample Iesults.

${ }^{\mathrm{d}}$ Duplicate $=$ Duplicate sample collected at the sample location, time and material.

TABLE 2 - ANALYTICAL RESLLTS FOR LEAD CONFIRMATION SOIL SAMPLES

\begin{tabular}{|l|c|c|}
\hline $\begin{array}{c}\text { SAMPLE } \\
\text { IDENTIFICATION }\end{array}$ & SAMPLE DATE & LEAD (mg/kg)" \\
\hline \hline EPA Region IX PRG for lead & $-750 \mathrm{mg} / \mathrm{kg}$ & \\
\hline \hline CAU143Pb-V01 & $01 / 09 / 2002$ & 3.4 \\
\hline CAU143Pb-V02 & $01 / 09 / 2002$ & 81.0 \\
\hline CAU143Pb-V03 & $01 / 09 / 2002$ & 3.4 \\
\hline CAU143Pb-V04 & $01 / 09 / 2002$ & 328.0 \\
\hline CAU143Pb-V05 & $01 / 09 / 2002$ & 292.0 \\
\hline CAU143Pb-V06 & $01 / 09 / 2002$ & 22.8 \\
\hline CAL143Ph-V06/Dunlicatei & $01 / 09 / 2002$ & 16.4 \\
\hline
\end{tabular}

Noles:

${ }^{\mathrm{N}} \mathrm{mg} / \mathrm{kg}=$ milligtans per kijogram

EPA, 1996.

${ }^{c}$ Duplicate $=$ Duplicate sample collected at the sample location, time and material. 


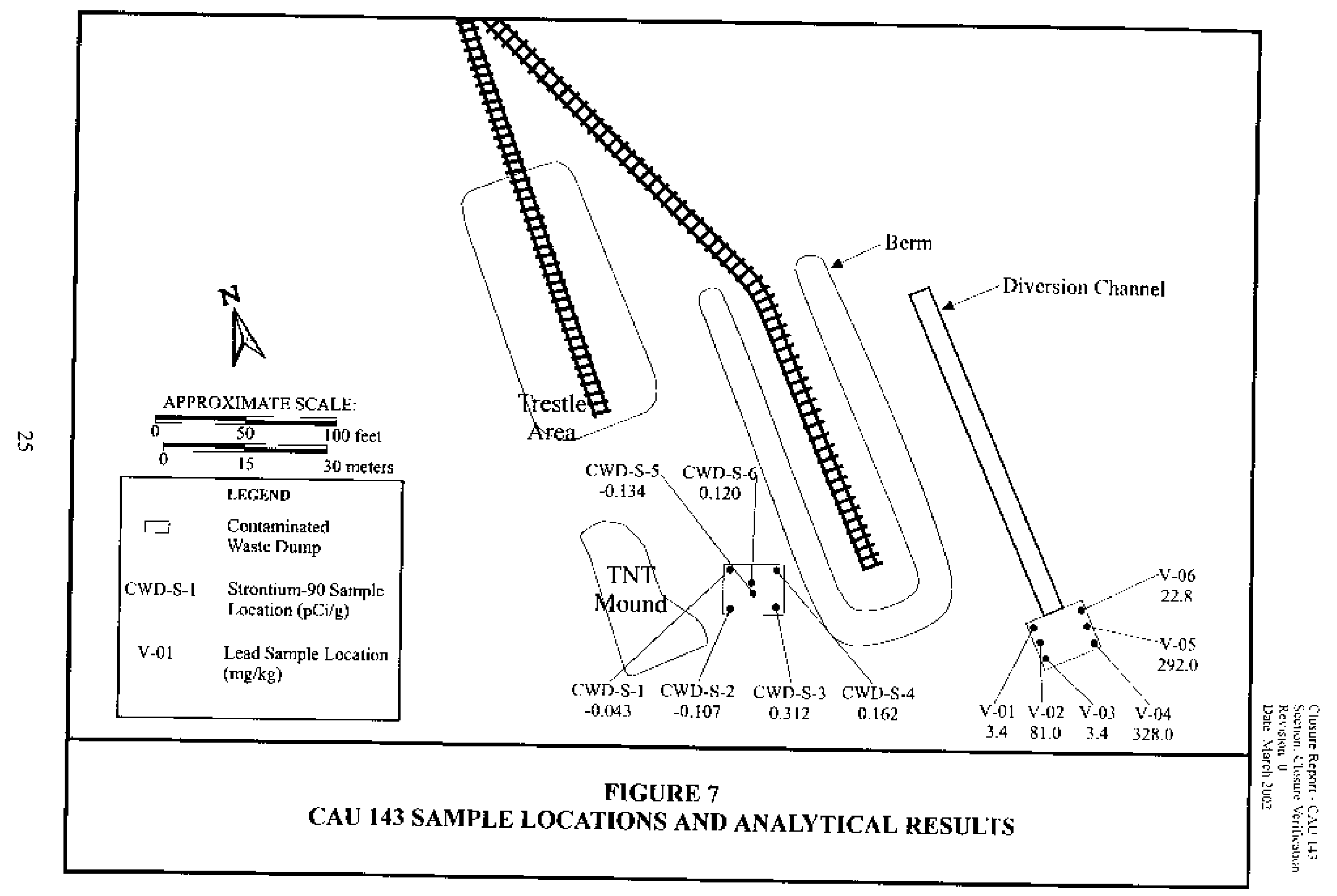


Clogure Rerial' - CA! 14:

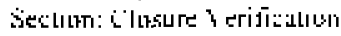

Ferision: 01

[hac: March 30

THIS PAGE INTENTIONALLY LEFT BLANK 


\subsection{CONCLUSIONS AND RECOMMENDATIONS}

Closure of the Area 25 CWDs was acconplished by completing the following tasks:

- Removal of Sr-90 impacted soil at the R-MAD CWD.

- Backfilling lopographic depressions in and around the R-MAD West Trenches E-MAD Trench, and the R-MAD East Trestle area,

- Regrading natural slopes tọ minimize infiltration, storn water runon/runoff and erosion.

- Installation of erosion protection via rip-rap rock and diversion channel to control the natural drainage flow and mitigate the polential of channelized erosion.

- Installation or a fencing and signage within and around the CWD areas to prevent unauthorized personnel from entering into the remediated areas.

\subsection{POST-CLOSURE MONITORING REQUIREMENTS}

The components of the Area 25 CWD post-closure monitoring plan are provided below.

\subsubsection{Inspections}

Inspections will be porfomed on an annual basis. Inspections will consist of visual observations to verify that the fencing is in good condition, proper signs are in place and are readable, and use testrictions are maintained. If any maintenance and repair requirements are identified, funding will be requested and the repairs scheduled. Any repairs will be documented in writing at the time of repair.

The post-closure inspection will consist or a detailed inspection of the fencing and postings within the R-MAD East Trestle area, around the West Trench area, around the E-MAD Trench area, and the interior and exterior of the R-MAD CWD. The R-MAD and E-MAD perimeter fencing will be walked by the inspector(s) and the condition of the fencing and postings will be documented in a single annual letter report. The letter report will include a discussion of observations and provide a record of maintenance activities. A copy of each annual letter report will be submitted to the NDEP.

\subsection{RECOMMENDATIONS}

Based upon the completion of site activities, it is requested that a notice of completion be provided by the NDEP for CAU 143. Upon closure approval, CAU 143 will be promoted from Appendix III to Appendix IV of the FFACO, "Closed Corective Action Units." 
Clusure kepor - C"Al! ]43

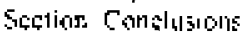

kerisın: 0

Tuan: Marcin 200 ?

THIS PAGE INTENTIONALLY LEFT BLANK 


\subsection{REFERENCES}

BN, see BechteI Nevada.

Bechtel Nevada, 2001a. Field Management Plan for Correclive Action. Unit 143: Area 25

Conlaminated Waste Dumps, Nevada Test Site, Nevada. October 2001, Las Vegas, NY.

Bechtel Nevada, 2001b. Site-Specific Health and Safetw Plan Por Closure Activities at Corroctive Action Unit 143: Area 25 Contaminated Waste Dumps, September 2001, Las Vegas, NV.

DOE/NV, see U.S. Department of Encrgy, Nevada Operations Office.

EG\&G 1968, Photograph Number 6811-19-41.

EPA, see L.S. EnvironmentaI Protection Agency,

FFACO, see Federal Facility Agreement and Consent Order.

OSHA, see Occupational Safery and Health Administralion.

Federal Facility Agreement and Consent Order (FFACO) of 1996 as amended. Agreed to by the Nevada Division of Envitonmental Protection, U.S. Department of Energy, and U.S. Department of Defense.

Occupational Safety and Health Administration, 1999. Titte 10 Code of Federal Regulations Chapter III, Part 835, "Occupational Radjation Protection," Rev. 1. Washington, D.C.

U.S. Envirormental Protection Agency, 1996. Region IX Prelininary Remediation Goals (PRGs), San Francisco, CA.

L.S. Department of Enctgy, Nevada Operations Office, 1999. Comective Action Investigalion Plan for Corrective Action Unit 143: Area 25 Contaminated Waste Dumps, Nevada Test Site, Nevada, Rev, 1, DOE/NV--506, Las Vegas, NV.

U.S. Department of Energy, Nerada Operations Office, 2000a. Corrective Action Decision Document for Cortective Aation Lnit 143: Area 25 Contaminated Waste Dumps, Nevada Test Sile, Nevada; Rev. 0, DOE/NV-617, Las Vegas, NV.

U.S. Department of Energy, Nerada Operations Office, 2000b. NV/YMP Radiological Control Manual, Rev, 4, DOE/NV/1 1718-079, Las Vegas, NV.

U.S. Department of Energy, Nevada Operations Office, 2001. Corrective Action Plan for Corective Action Uniz 143: Area 25 Contaminated Waste Dumps Nevada Test Site Nevada: Rev. 0, DOENV--698, Las Vegas, NV. 
Llosure Repuri - Chl l 4;

Jutc Mitris $2 \mathrm{MI}$

THIS PAGE INTENTIONALLY LEFT BLANK 


\section{APPENDIX A}

\section{"AS-BUILT" DRAWINGS AND ENGINEERING CALCULATIONS FOR CAU 143: AREA 25 CONTAMINATED WASTE DUMPS}


("Tisure Reppor - CA1: :4:

beten: Appendis

13. ision:

Dure? yarth 20 y

THIS PAGE INTENTIONALLY LEFT BLANK 


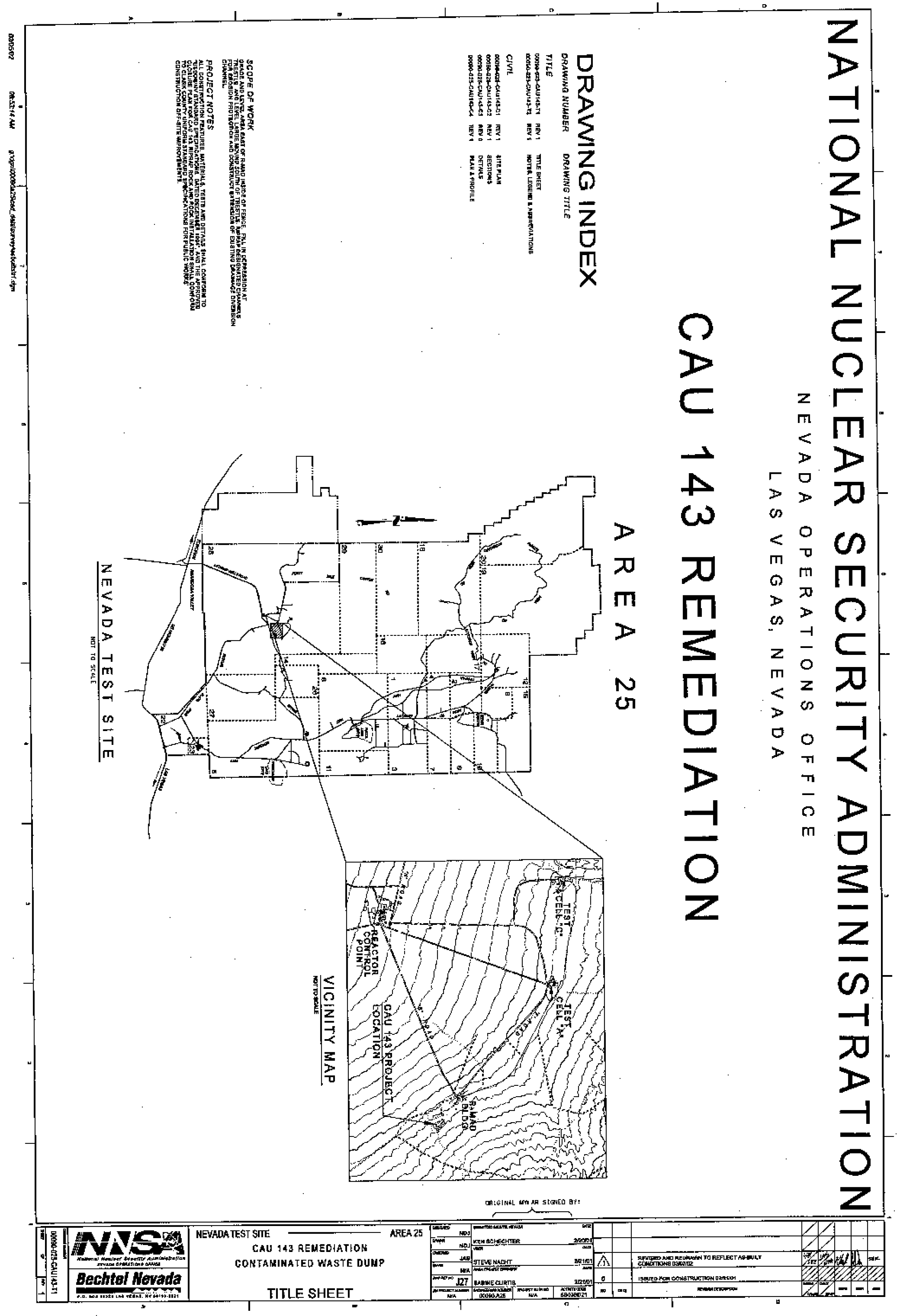


CIVIL LEGEND AND SYMBOLS

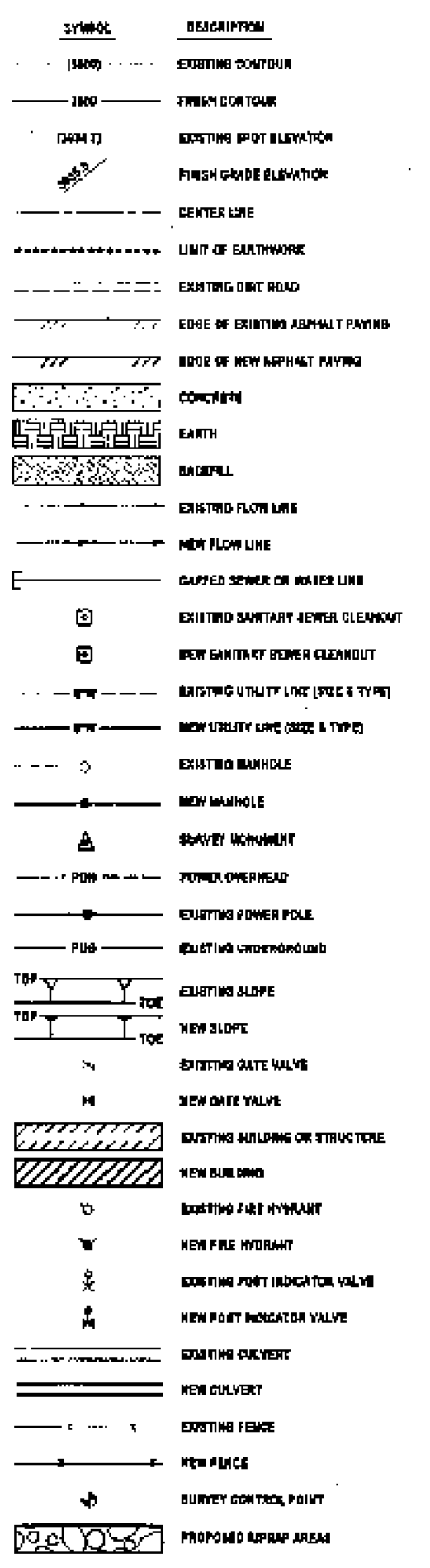

CIVIL LEGEND AND SYMBOLS
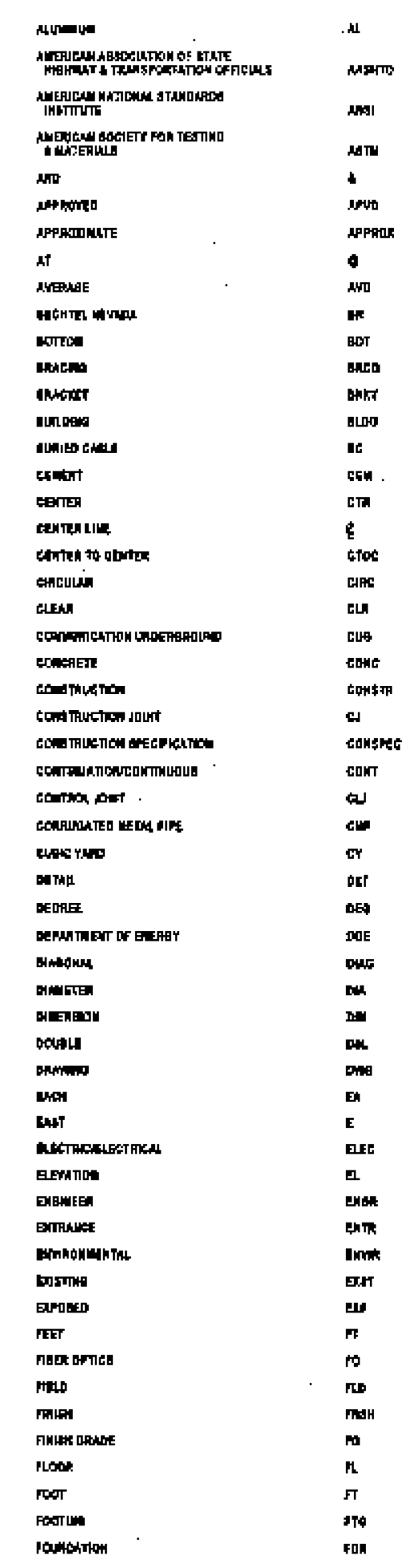

CIVIL NOTES

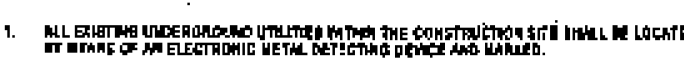

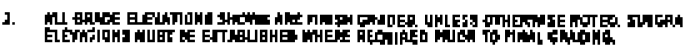

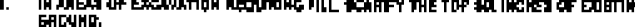

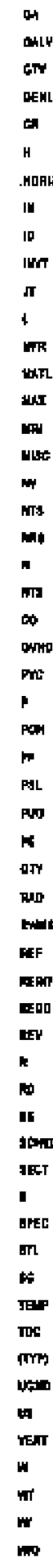

\section{REFERENGE}

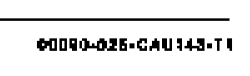

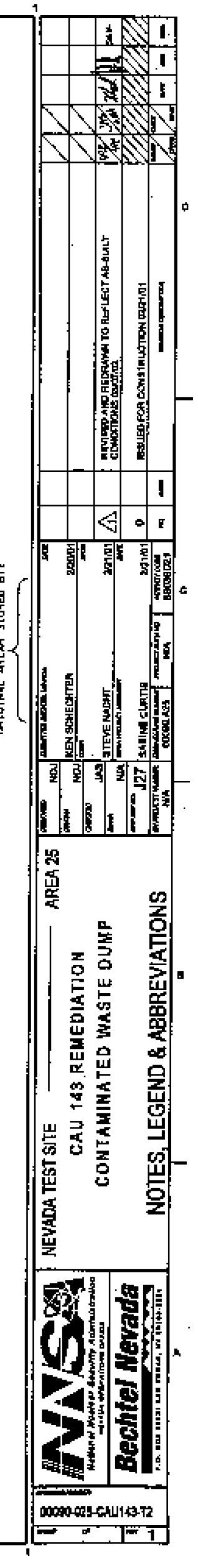

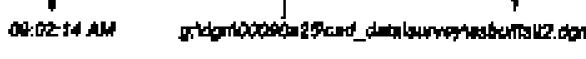




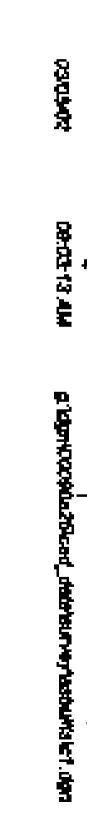



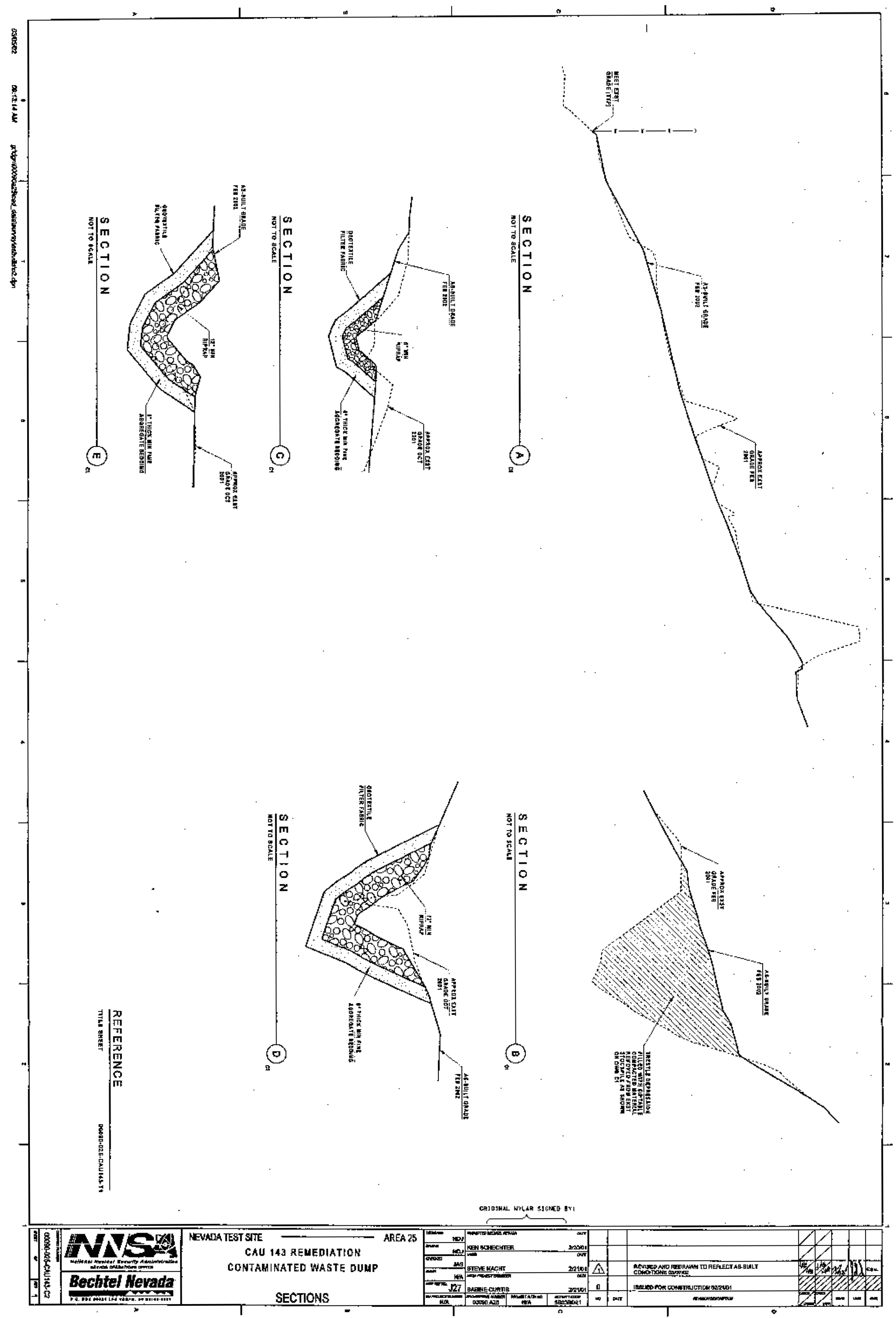


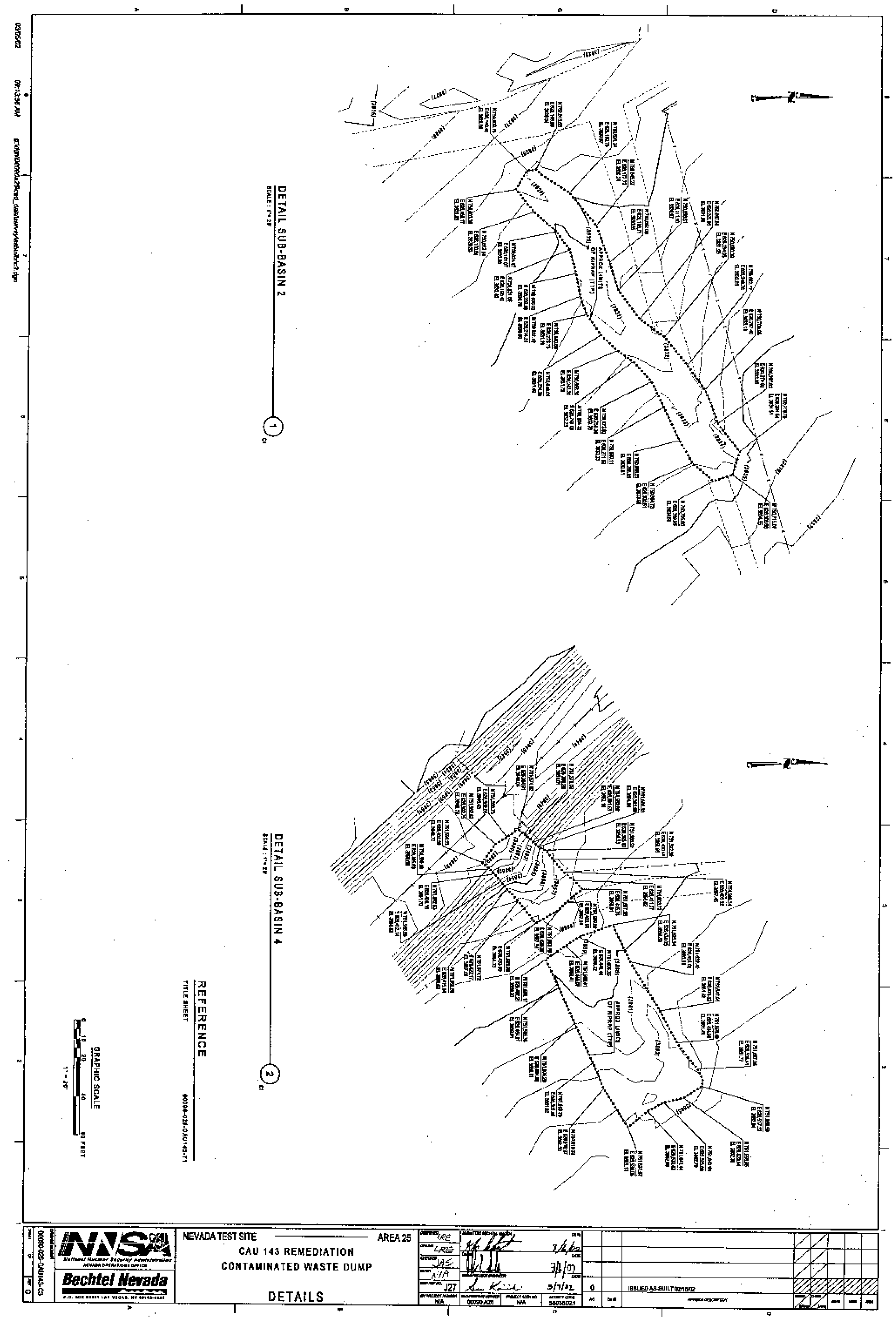




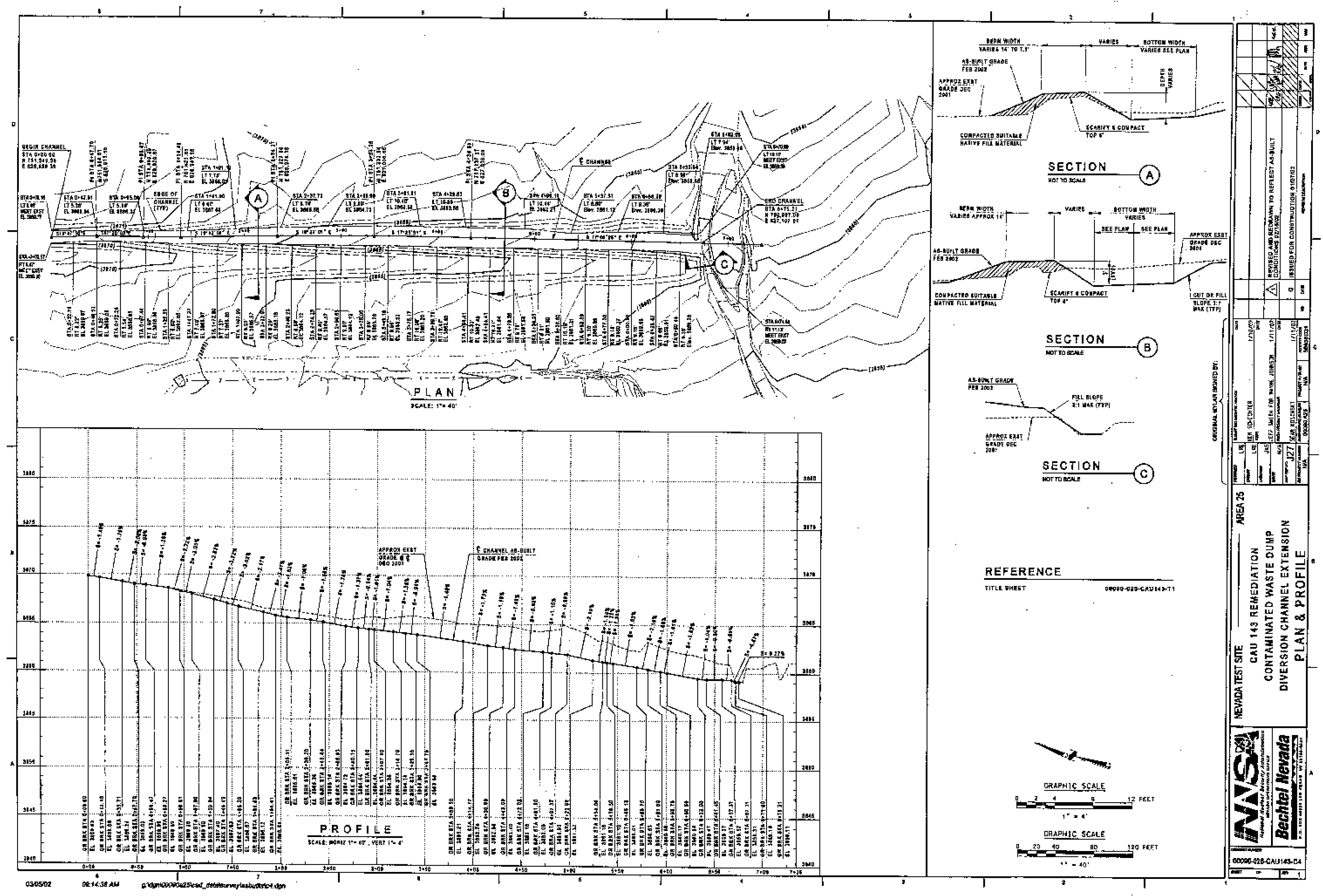




\section{ANALYSIS / CALCULATION (AC) COVER SHEET}

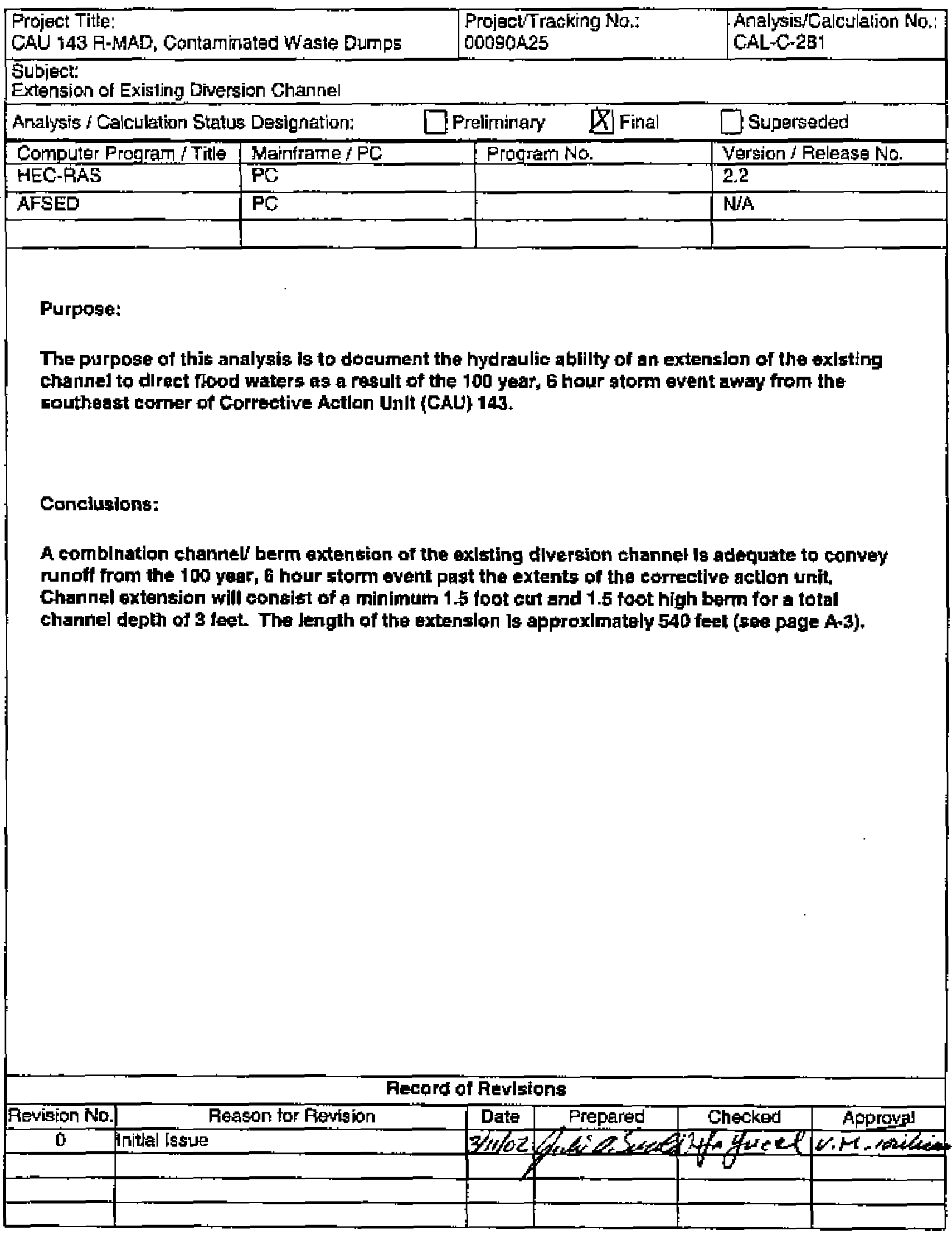




\section{ANALYSIS / CALCULATION (A/C) SHEET}

\begin{tabular}{|c|c|}
\hline $\begin{array}{l}\text { Prdject } \\
\text { CAU } 149 \text { F-MAD, Contarninated Waste Dumps }\end{array}$ & $\begin{array}{l}\text { AnalyglolCalculation ha: } \\
\text { CAL-C-281 }\end{array}$ \\
\hline $\begin{array}{l}\text { Subject: } \\
\text { Extension of Exusting Diwersion Channel }\end{array}$ & \\
\hline Date $\quad 3 / \alpha<2$ & Prepared $Z Z s$ \\
\hline
\end{tabular}

Sestion

\section{Table of Contents}

Purpose:

Page Number

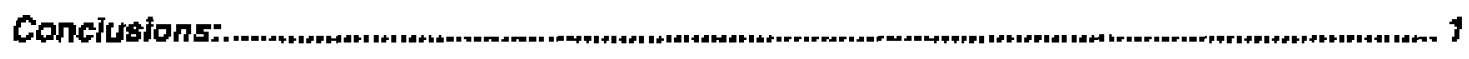

Dpen Hens:

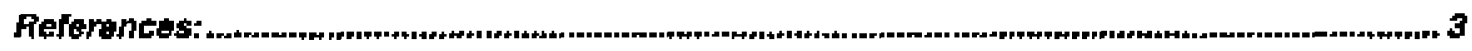

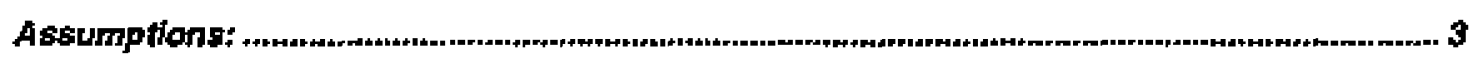

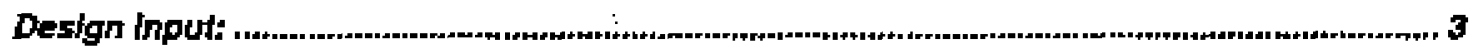

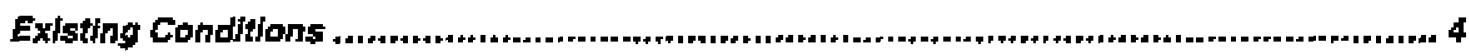

Cajeulations: -

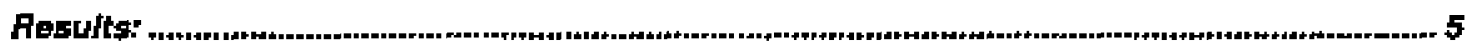

Grein Size Digtribution Curve:.............................................................................4-1

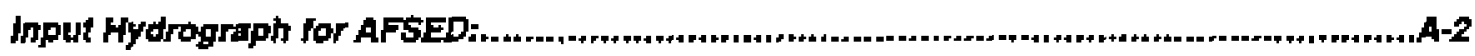

Diversion Chanhel Extension Plan \& Profile................................................................4-3

Water Surface Profles....................................................................................A-4

Certification of Flood Mitipation Structures at the Area 5 RWMS..............................4-5\&6 


\section{ANALYSIS / CALCULATION (A/C) SHEET}

\begin{tabular}{|c|c|}
\hline $\begin{array}{l}\text { Prolect: } \\
\text { CAU } 143 \text { R-MAD, Contarninated Waste Dumps }\end{array}$ & $\begin{array}{l}\text { Analygis'Caloulalien ND.: } \\
\text { CAL-C-2B1 }\end{array}$ \\
\hline \multicolumn{2}{|l|}{$\begin{array}{l}\text { Subject } \\
\text { Extension of Existing Diwersion Channe! }\end{array}$} \\
\hline Dale $3 / 0 / 42$ & Prepared 745 Checked $L$ th \\
\hline
\end{tabular}

\section{Open ltems:}

1. None

\section{Feterences:}

1. Fichard H. French, "AFSED: A Sute of Models for Estimating Sediment Transport During Flood Events on Alluvial Fans." Water Resources Center, Desert Fesearch Ingtitute, Sept. 1996.

2. Clark County Regional Flood Control District (CCRFCD). Hydrologic Chiteria and Drainage Design Mantal, 1999 Edition.

3. U.S. Army Corps of Engineers (COE 1996). Alver Analysis System (HEC-RAS Computer Frogram): Davis, Californla, paginated by section, 1996.

4. Bechtel Nevada. Cakulation AC-00090.A25-C-189 Revision O, Februery 2001.

5. Bechtel Nevada. Calculation AN-00090.A25-C-184 Revicion 0. Febutary 2001, page 22.

6. F. H. French and S. Curtis. The Precipitallon Event of 23-24 February 1998. Publication No. 45170. Desert Research Insthute, June 1999.

7. Bechtel Nevada. Calculation FD-DA-C-117 Revision 1, Octaber 1999.

8. Leter to Mr. John Carill from R;..H. French. Certification of Flood Mitgation Strugtures at the Area 5 AWMS, November 1999.

\section{Assumptions:}

1. Ail cross-section Information contained in Reference 4, upstream of avabable survey data are valid. The entire channel was not surveyed. Cross section information in the HEC-RAS moded, upstrearn of the extension, is based on field measurements. I hese feld measurements were parformed by BN hydrologists in 1999 (REF 4).

2. Manning's n value of 0.035 to sccoumt for naturally occuming revegetation of the channel axtension within the main channel (Same as used in reference 4).

3. Manning's $n$ value of 0.04 in the overbank areas [Same as used in reference 4].

4. For purposes of gediment transport, the inflow of sediment from the upstream basin will occur at the beginning station of the existing chan, al and will not affect the channel extension.

5. The Kiwi Mesa Alluvial Fan is ectwe. This means that the existing natural channels are not stable and can move back and forlh across the farn.

\section{Design Input:}

1. Channel discharge of $270 \mathrm{cfs}$ Irom the 100 year, 6 hour stom gwent (REF 4).

2. HEC-RAS file:

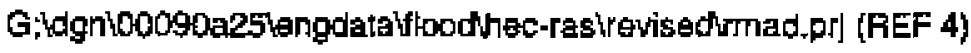

3. Topographic survey data files:

G:'dgnooogoa25icaddata'survaydecothecoradd-asc

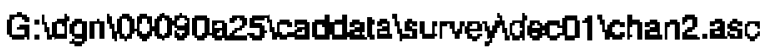

4. Inroads design date files:

Gidgnho0090a25icaddatahsurveydeco1'sub_b05a.ttm

G:'dgn'00090a25hcaddala'surveyhdec01 tchannel.elg

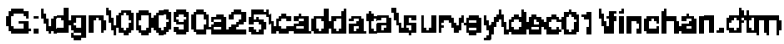

5. Sediment size data - Fólerence 5. See attached page A-1. 
ANALYSIS / CALCULATION (AVC) SHEET

\begin{tabular}{|c|c|}
\hline $\begin{array}{l}\text { Project: } \\
\text { CAU } 143 \text { R-MAD, Coniaminated Waste Dumps }\end{array}$ & $\begin{array}{l}\text { Analysis/Caleulation Mo.: } \\
\text { GAL-C-281 }\end{array}$ \\
\hline \multicolumn{2}{|l|}{$\begin{array}{l}\text { Subject: } \\
\text { Extension of Existing Diwergion Channel }\end{array}$} \\
\hline Data $\quad 3 / 4 / a Z$ & 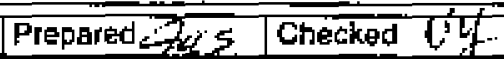 \\
\hline
\end{tabular}

6. Hydrograph tor concentration point CP3 - Feterence 4. See attached page A-2 for this date in format requirsod by AFSED.

Exstlng Conditions:

On 11/21/01, project management requested an engineering represeritative to visit the site to assess the currant draknage conditions. This site visit occurred on 11/26ro1. Of particular concem was the southeast cormer where erosion has been occurring inside the fornce at the toe of the existing berm. This same erosion pattern was evident in the previous topographic sunvey that was performed for desigr 2 years ago.

To the east of the CAU is an exlsting channel that has not begn maintaingd. The average width of this chennel is 20 feet. The aurage side slopes are approximately $2: 4(\mathrm{H}: \mathrm{W} / \mathrm{l}$. Previous field measurements along this channel indicate depths from 1 (north end) to 3 foet (south end). Average depth is approxinately 1.5 foet. It appears that the cut from this construction was placed as a berm on the downstream side.

Field personnel pointed out that this berm had been breached. Many years ago a road had been built through this channel. This toad toliows an existing drainage wash. Currenty, at the location of this road, there is a blockago of the channal. This has caused the flow to back up and overtop the berm. This whter then sineet flows towards the berm inside the tence.

The existing grading Inside the tence is such that unoff from the berm and the arga inside the fence is foreed to converge (concentrate) al the point that the eroslon cut begins at the toe of the bemin. If the channel berm is hot repaired and the blocksge removed, the extents of the riprap will nead to be increased to prewent turther erosion inside the fence.

Currenty, there is no well-defined autet for the channel. The area outside the fence has been cleared, following the terraln, for staging of iprap prior to placement. Frior. small drainage features have been obliterated. Aerial pholos indicate that the existing channel did not extend far enough south to get the water past the unit. The channel did drain into an existing drainage feature, but this feature drained to the toe of the built up area inside the fence. Most of the water currently impacting the unit appears to be the result of the road bullt through the existing channel many years ago.

The HEC-RAS analygis of this channel performed during THtle I design indicates that the channel extension would need to be approximatsty 3 feet deep for the existing bottom width of 20 feet. This depth can be acoomplished with a combination of a cut depth of 1.5 fost and using the cut material to beriti a helght of 1.5 foet on the dowrstream side. Asty cut material not required for berms can be used to regrade the area between the CAU and the chanril. Gurrently the chamed shows no signs of appreciable erosion. Therefore, the extension should perforrs equally well for long term protection.

\section{Calculations:}

The HEC-RAS file devaloped during Title I design was reviegd to reflect the channel extension (no chenge in Tite (1). The channel extension Bs designed to cksely epproximate the existing enannel cross section, i.e., awerage bottom width and depth. The side slopes ware changed to $3: 1(\mathrm{H}: \mathrm{W})$ so that the expertobn would mest the requirements contained in reference 2 . The river statlons were revised to coinclids with the desgned extension stationing. Boundary flow conditions remainet the same.

River Station (AS) 2657.71 cotricides with RS 3000 (REF 4).

FS 1907.71 coinoides with RS 2250 (FEF 4).

FS 1157.71 coincides with RS 1500 (AEF 4).

The remaining RS's are new with station eleyation data taken from survey/linroads data fles. 


\begin{tabular}{|c|c|}
\hline $\begin{array}{l}\text { Project: } \\
\text { CAU t43 R-MAD, Conlaminated Waste Dumps }\end{array}$ & $\begin{array}{l}\text { Analysis/Caleulation } \$ \text { D. } \\
\text { CAL-C-28t }\end{array}$ \\
\hline \multicolumn{2}{|l|}{$\begin{array}{l}\text { Subject: } \\
\text { Extension of Existing Diversion Channel }\end{array}$} \\
\hline $3 / 462$ & 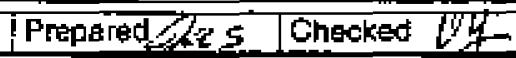 \\
\hline
\end{tabular}

Hydraulic parameters generated during the HEC-RAS computer run (page 1t) were used to check the flow stability (page 8), the required freeboard, and the required channel depth per the requirements contained in reference 2 (page 9). The file developed during Title I was nun again to cakculate the critical water surface elevation at each beation along the existing thanne. These hydraulic parameters (page 10) were used to check the flow stability (page 6), the required freeboard, and the required channel depth of the existing chantnel (page 7). These three values had not been previpusily addressed as the original design criteria did not involve modiflcations to the existing channel.

The hydraulic and geometric parameters were also used to estimate the deposition in the area of transition from axisting to new channel using AFSED (FEF 1) (pages 19 to 39). The slope of the existing channel at the transition location is steeper than the design slope of the new extension resulting in deposition rather than scour at this location. A grain Size D|stribution curve developed from a sample taken at the southeast comer of the CAU (FEF 5) (page A-1) was utilized in the AFSED model. The hydrograph for CP3 (REF 4) (page A-2) was also used in the AFSED model.

Sediment trangport was not addressed for the existing channel as the inflow from the basin is assumed to occur at the beginning of the channel and the slope of the channel is assurned to be falty uniform.

Results: (See pages 6 to 39)

Both the existing channel and new channel extension. have areas of flow instability per criterta conlained in. reference 2.

Neither the existing thannel nor the new channel extension has the required depth to meet the minimun freeboard requirements contained in reference 2. However, consictering the depth required to contain only the clearwater flow with an astimated deposition depth (maximum) of 0.27 feet (pages 37 to 39), both the existing channel and new channel extenslon are adequale to contain the tlow from the 100 year, 6 hour storst event without owertopping the banks.

Both HEC-AAS analyses indicale two locations where a portion of the flow leaves the chennel (pages 12 \& 14). Station 2657.71 (3000) is the beginning of the channel and station 1157.71 (1500), which is the midpoint of the channel. The existing drainage pattems at these locations Indicate that this flow would not impact CAU 143 at the southisast comer.

In February of 1998. a regional precipitation event of a larger magnitude than the design storm actually occurred over the Novafa Test Slte (NTS) (REFG). There is no visual evidence that flow in the existing channel overtopped the banks at any point along lts length, except where the road had been cut through the charinel. There is asso no indication of excessive scour or deposition. The apparent conflict between modeling results and visual observation is due to the conservatism of basin loss rates and not accounting for channet transmission losses within the HEC-HMS and HEC-RAS models.

Even though the existing channel and extension do not megt minimum fregboard or flow stabilty requirements contakned in reference 2 (based on model results), there has been precedence set at the NTS for acceptance of the adaquacy of flood control structures under these conditions (REF 7 and REF B). Soe page A-5 for copy of letter cerlifying the Area 5 Flood Controt Structures, which also did not meet stability or minirnum freeboard requirements contained in reference 2, but did not owertop the banks. 
Preparad Ey

Checked By:

Row.F. $\rho^{2}$ Page 6 of 39

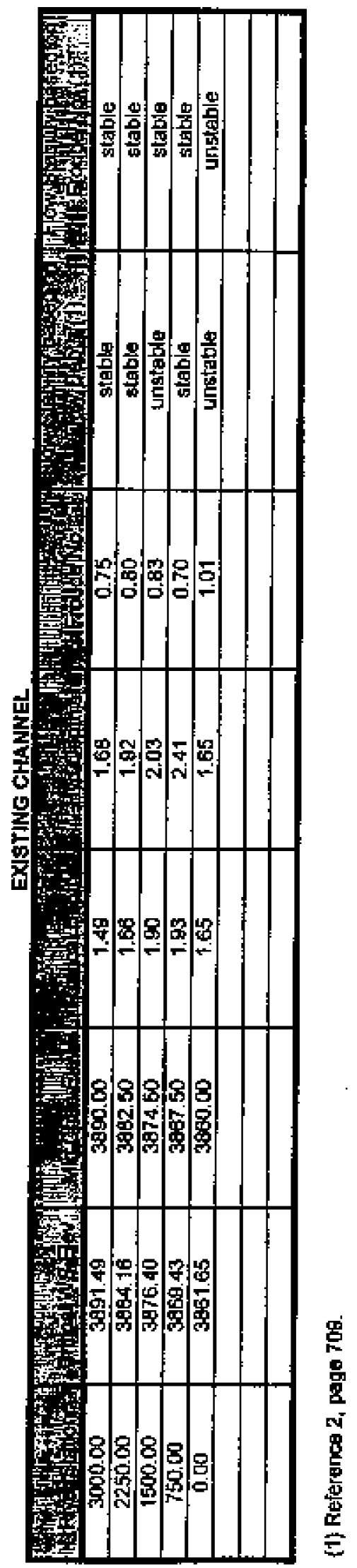



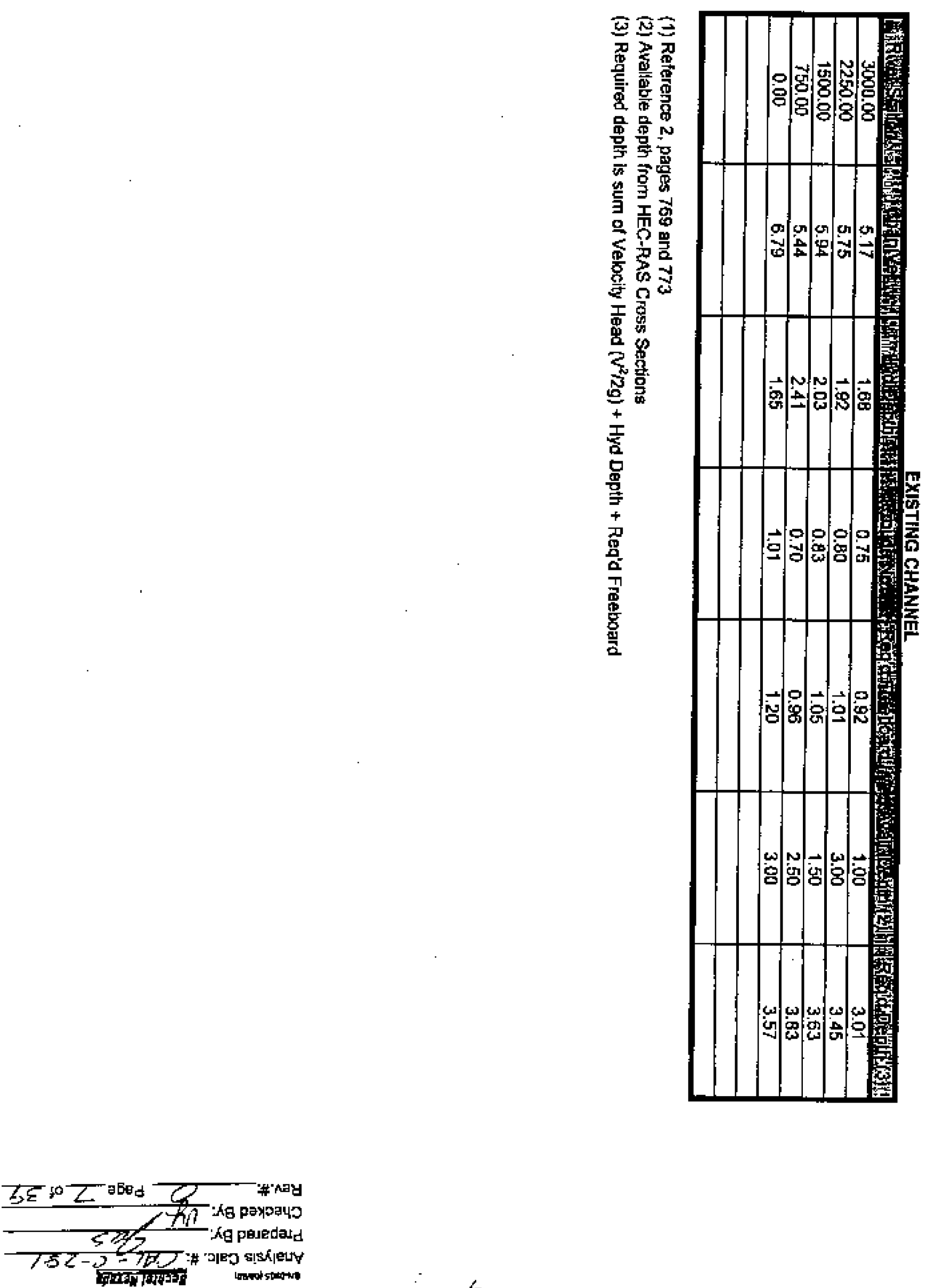

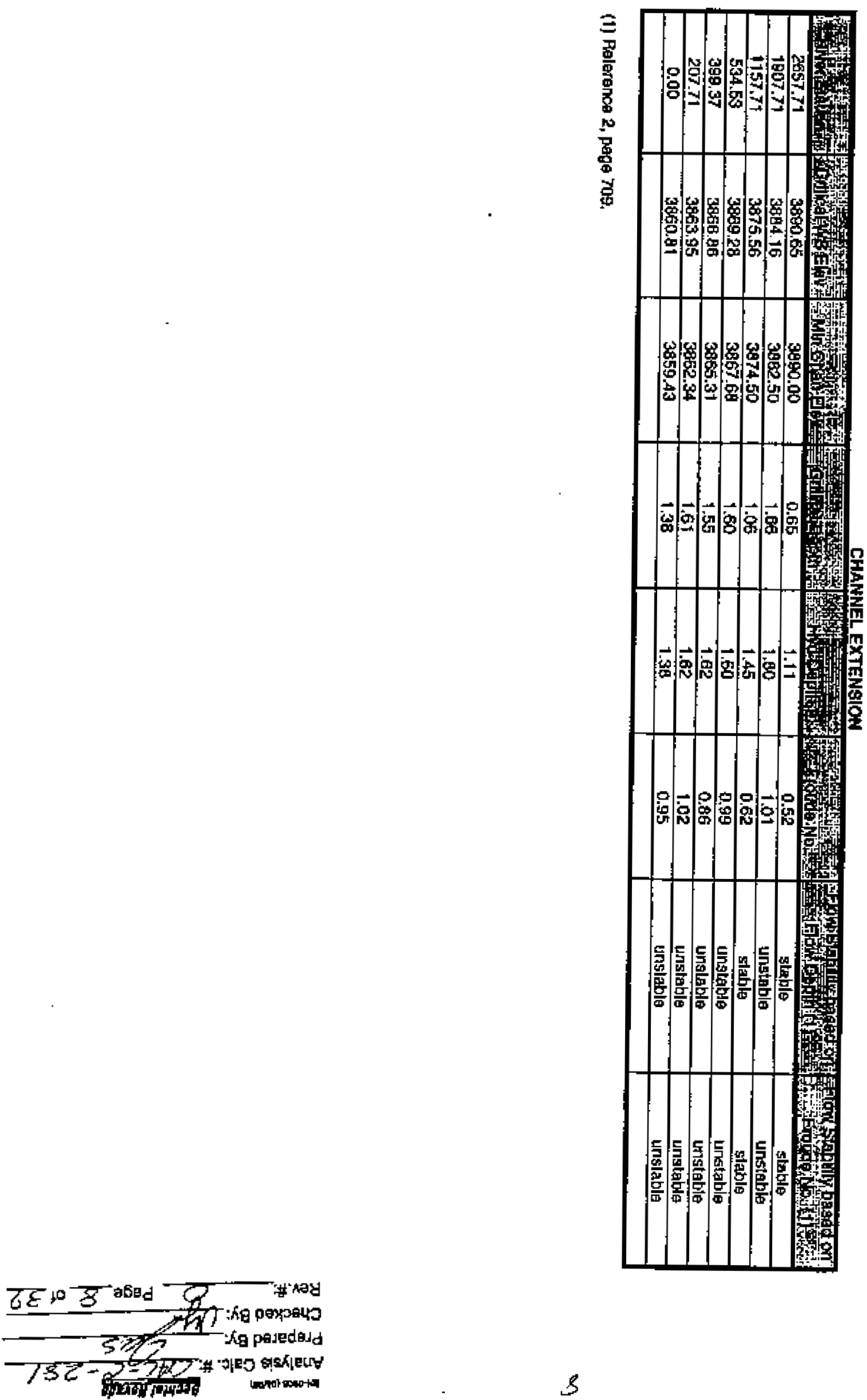

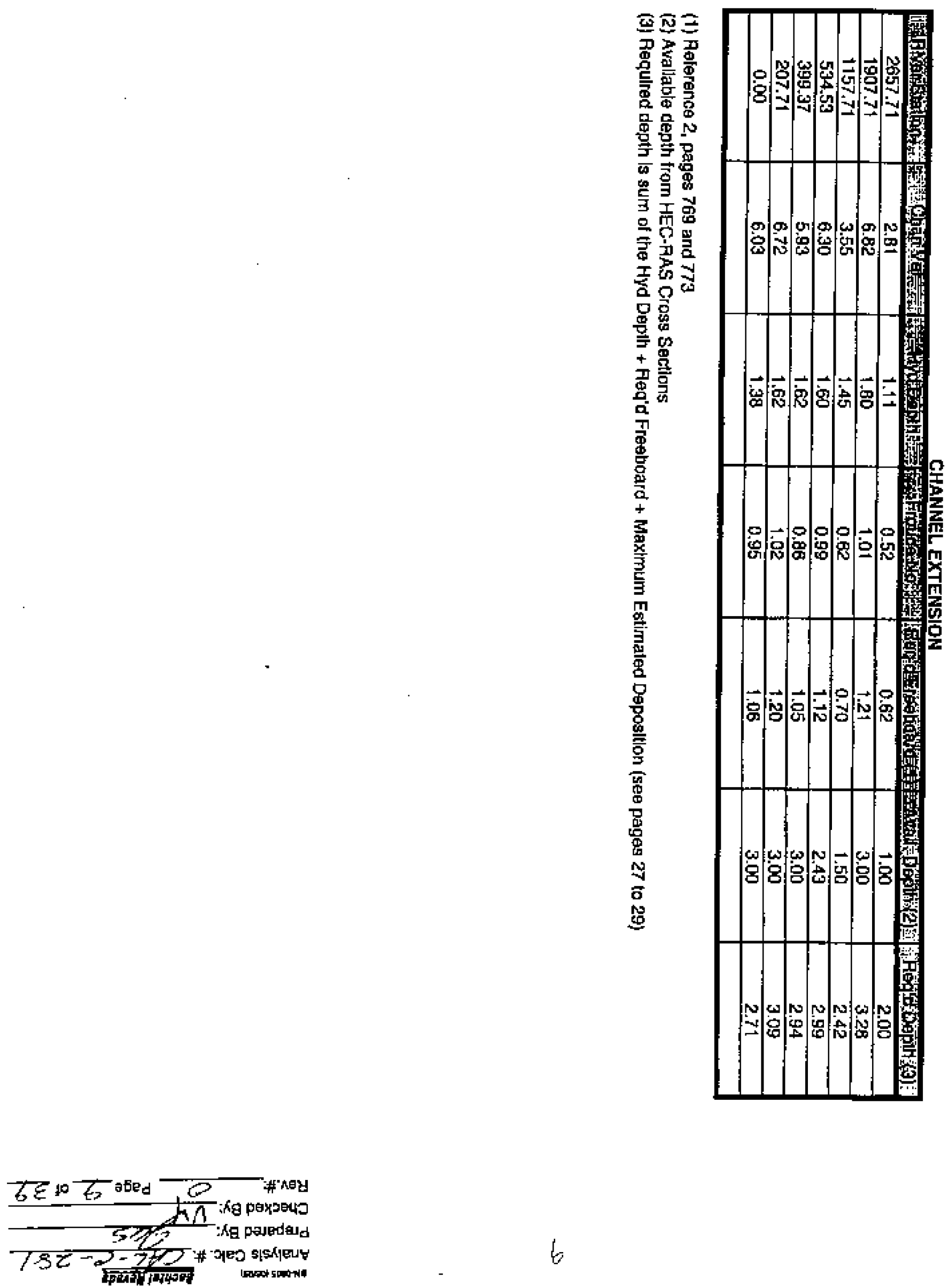


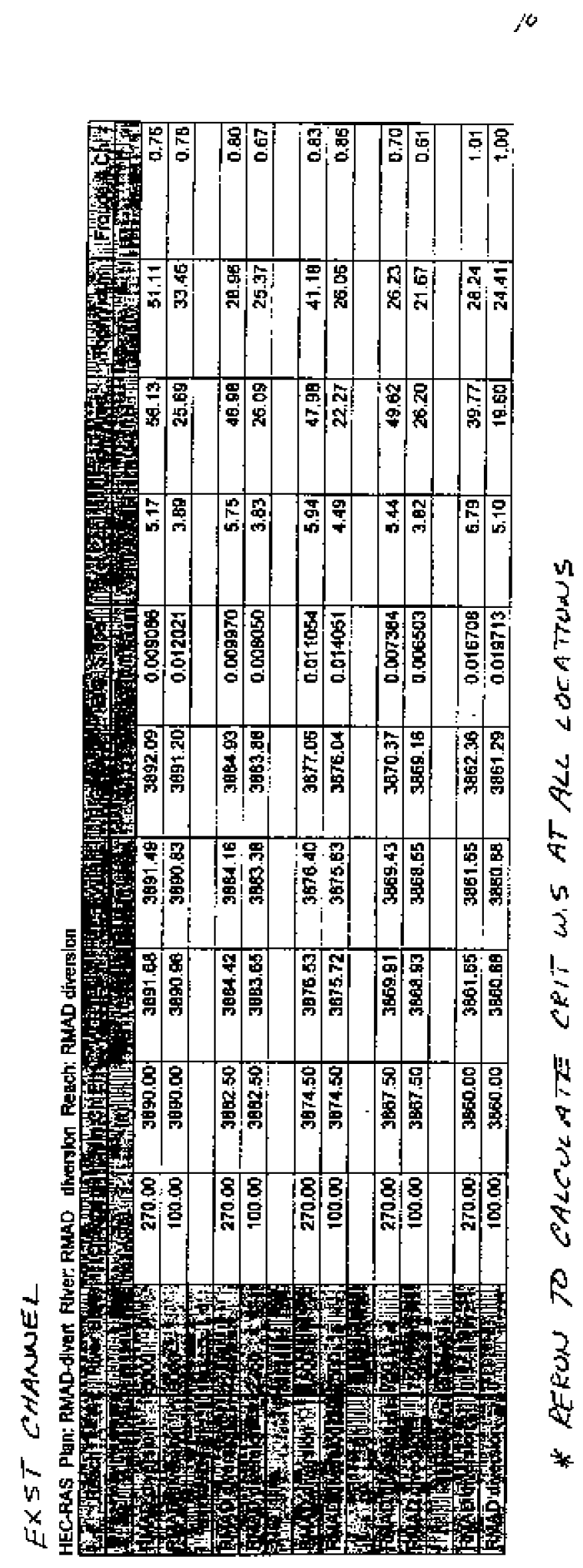




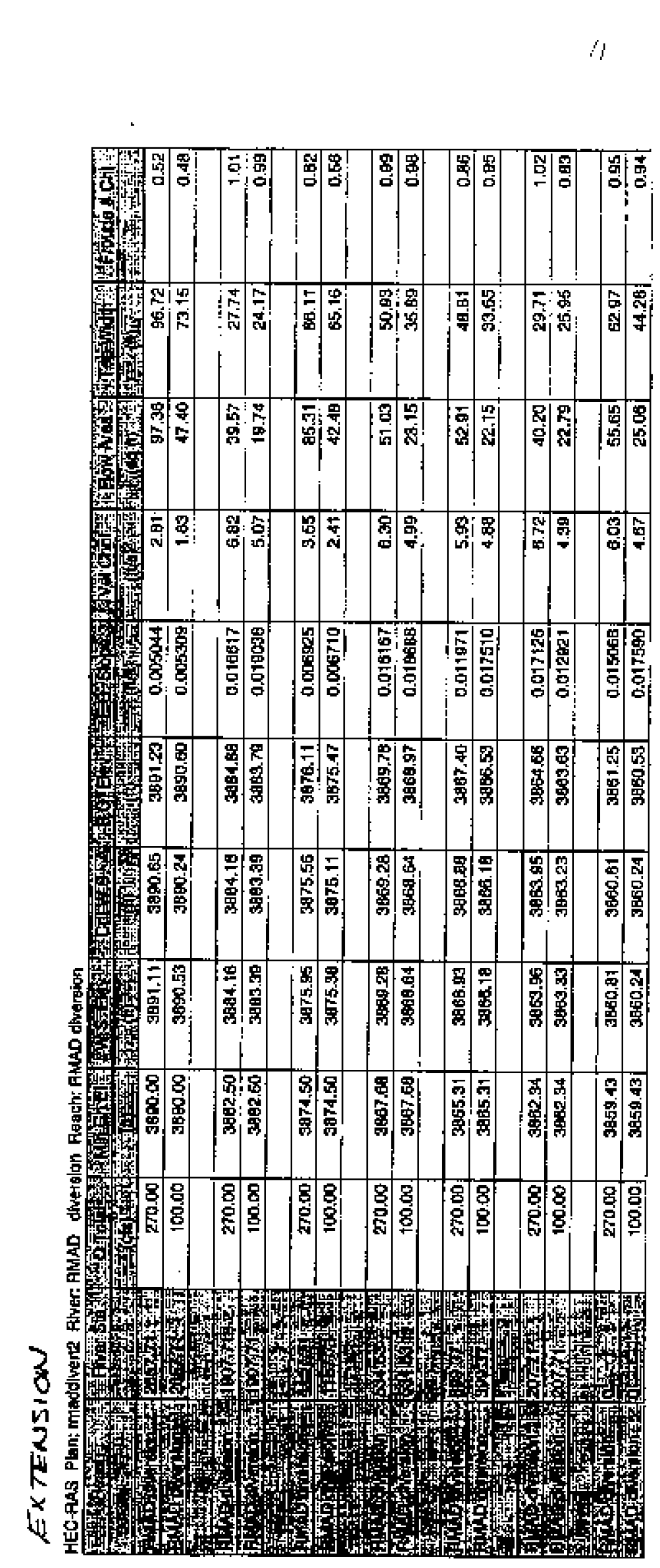




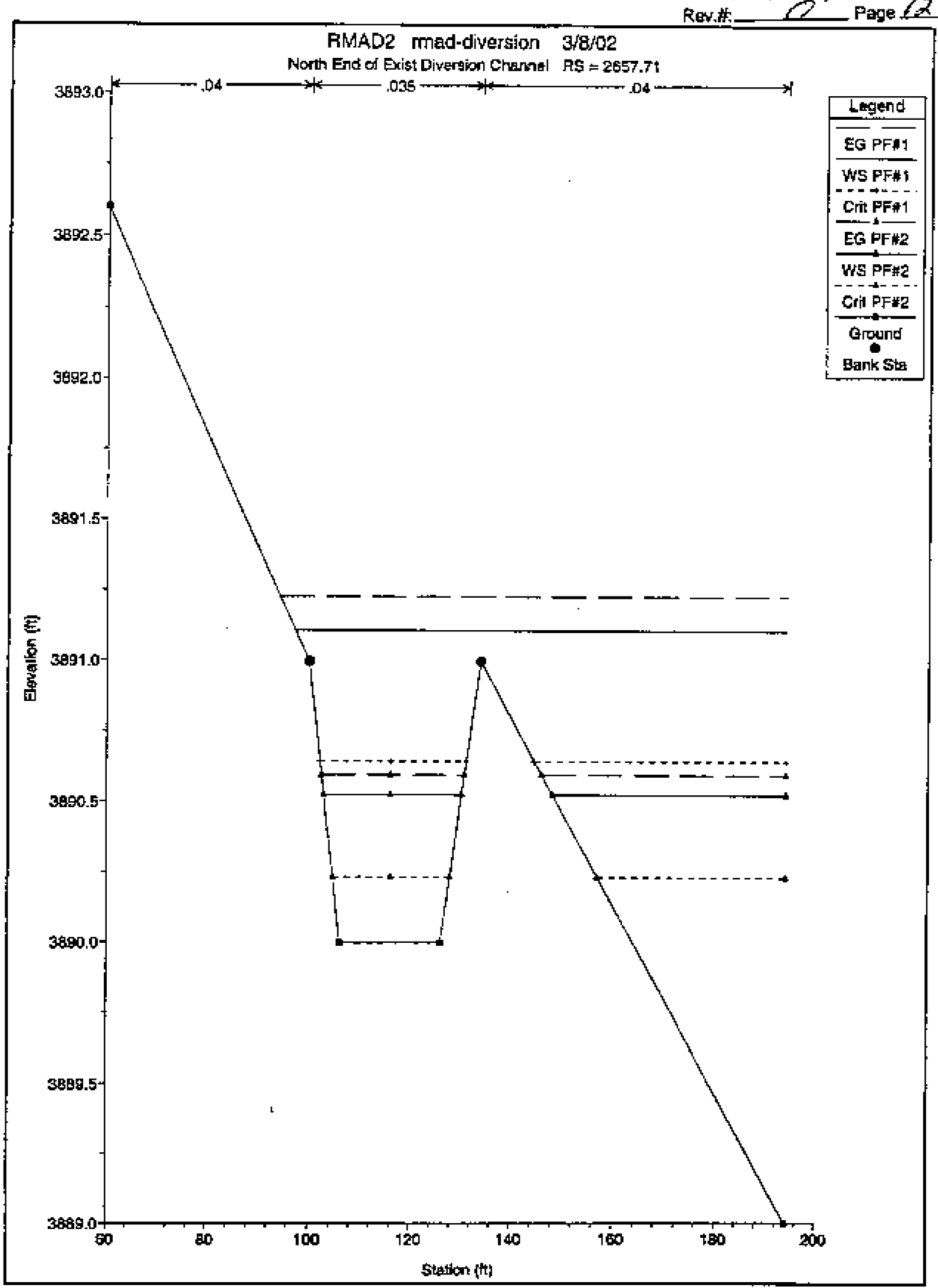




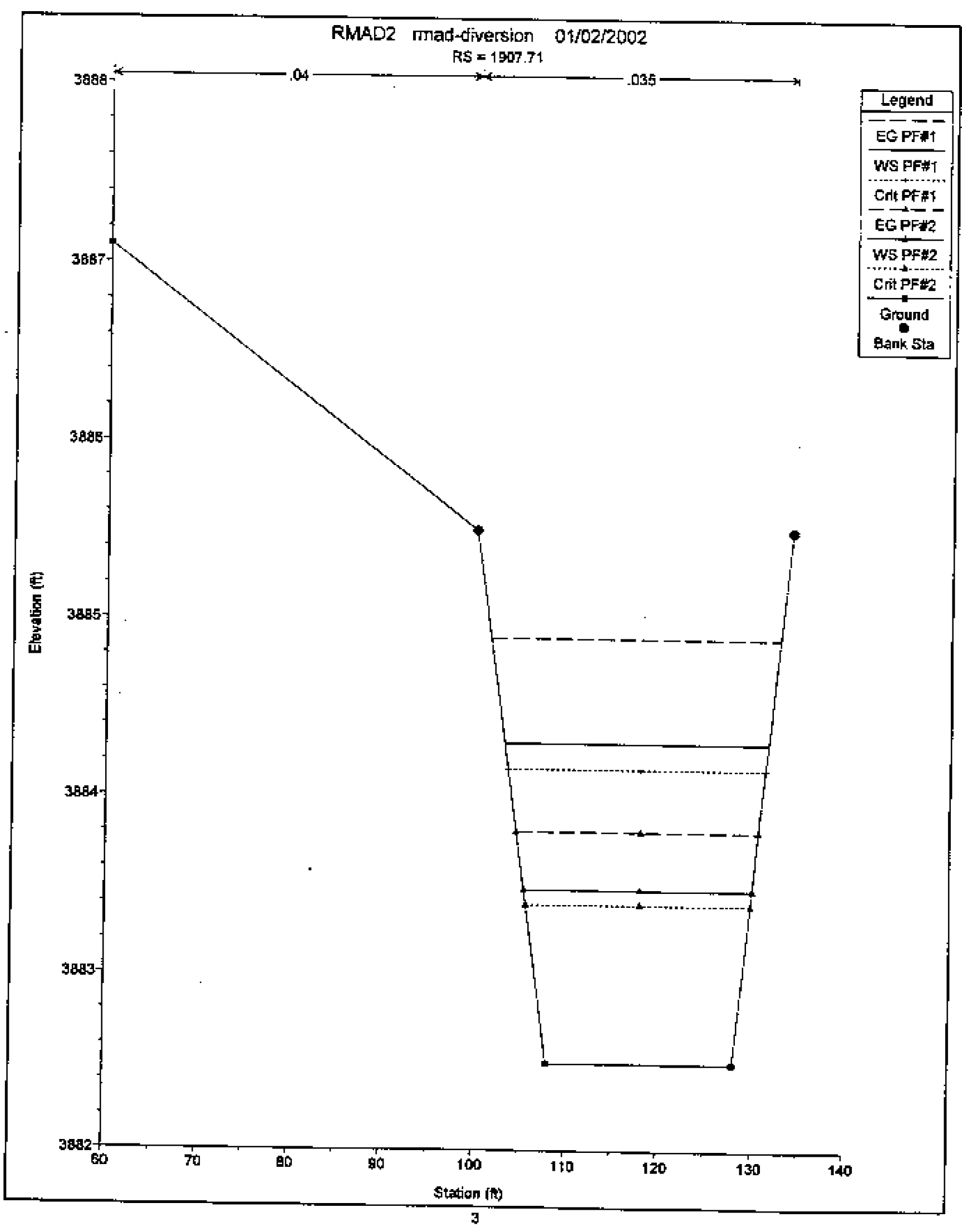




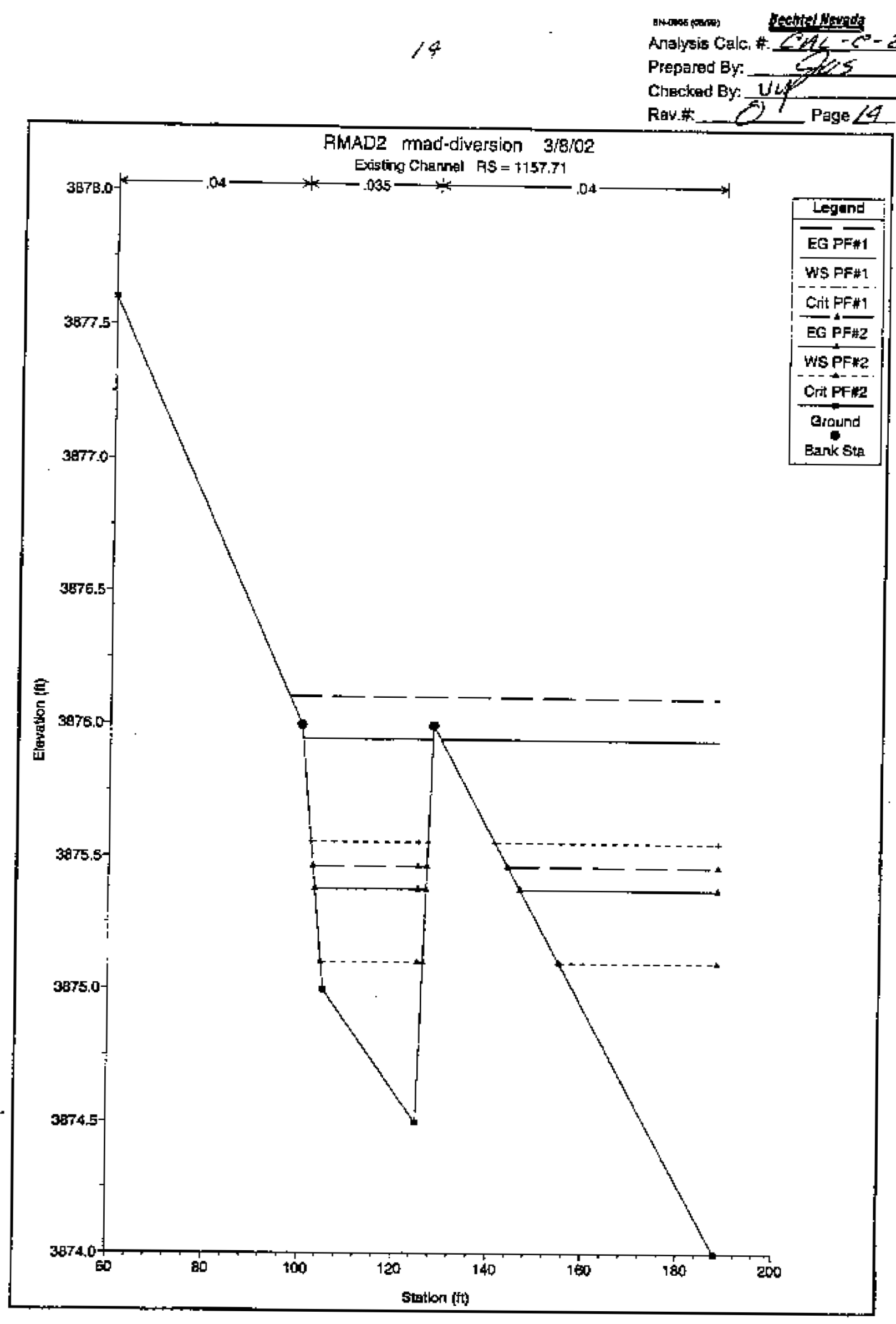




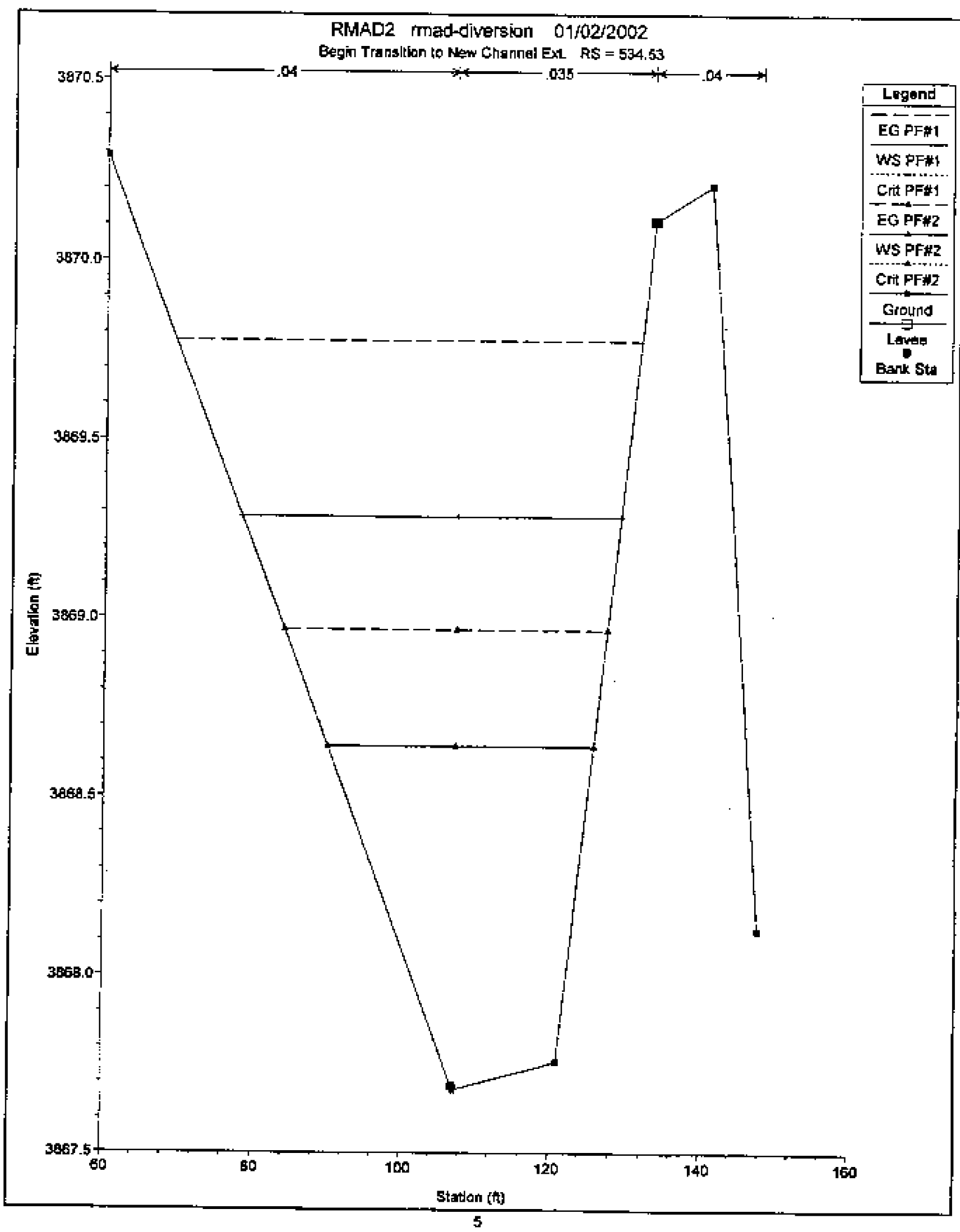




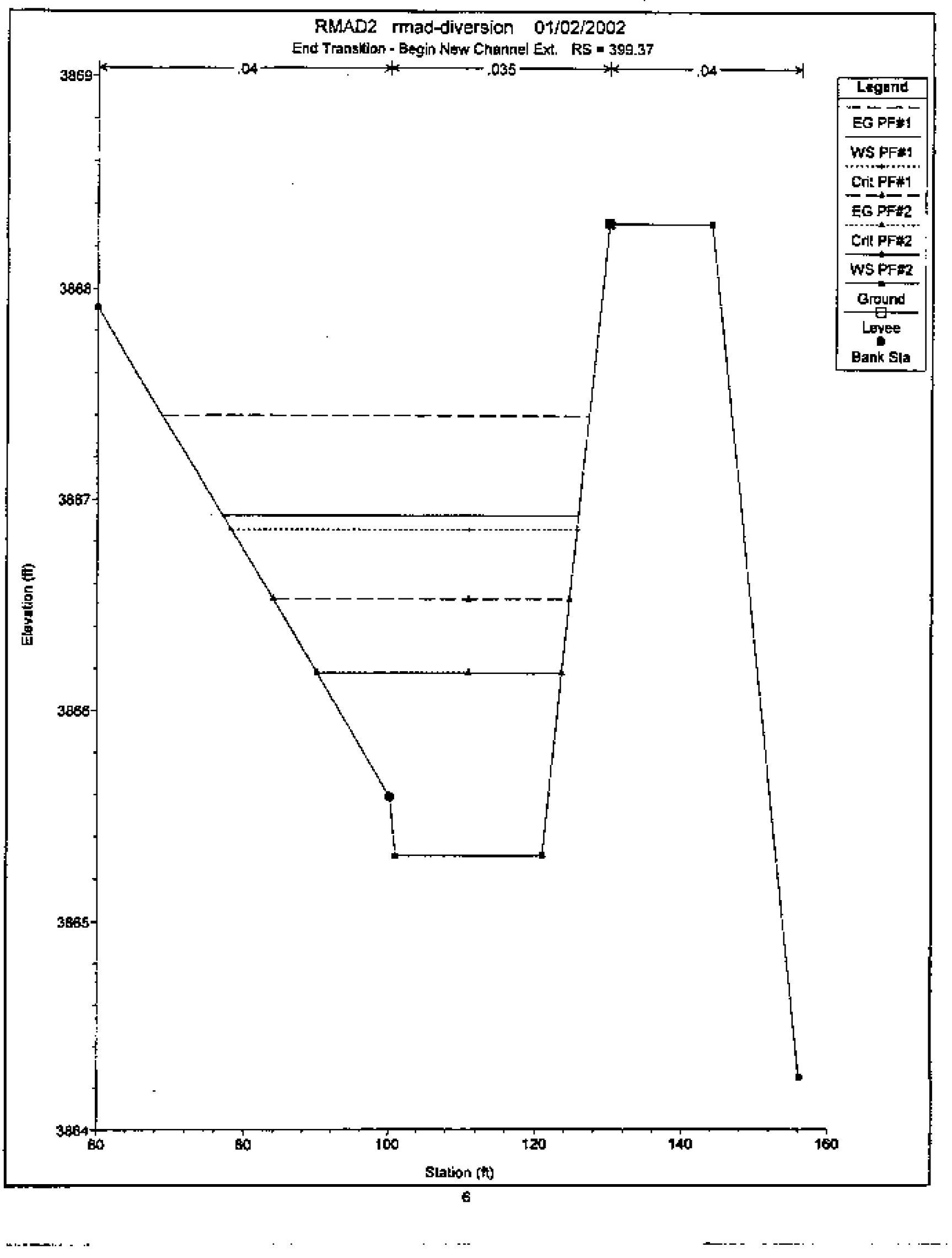



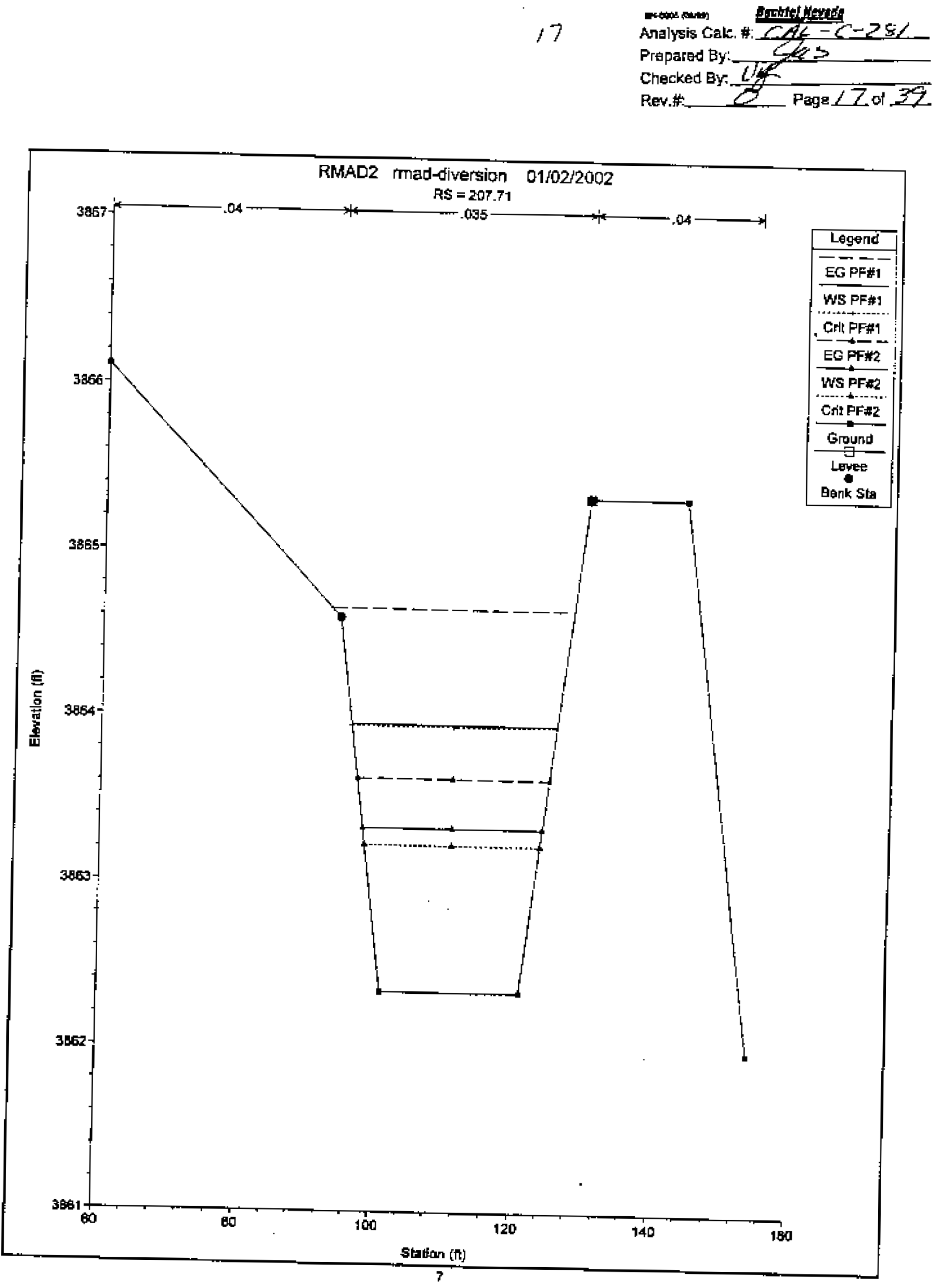


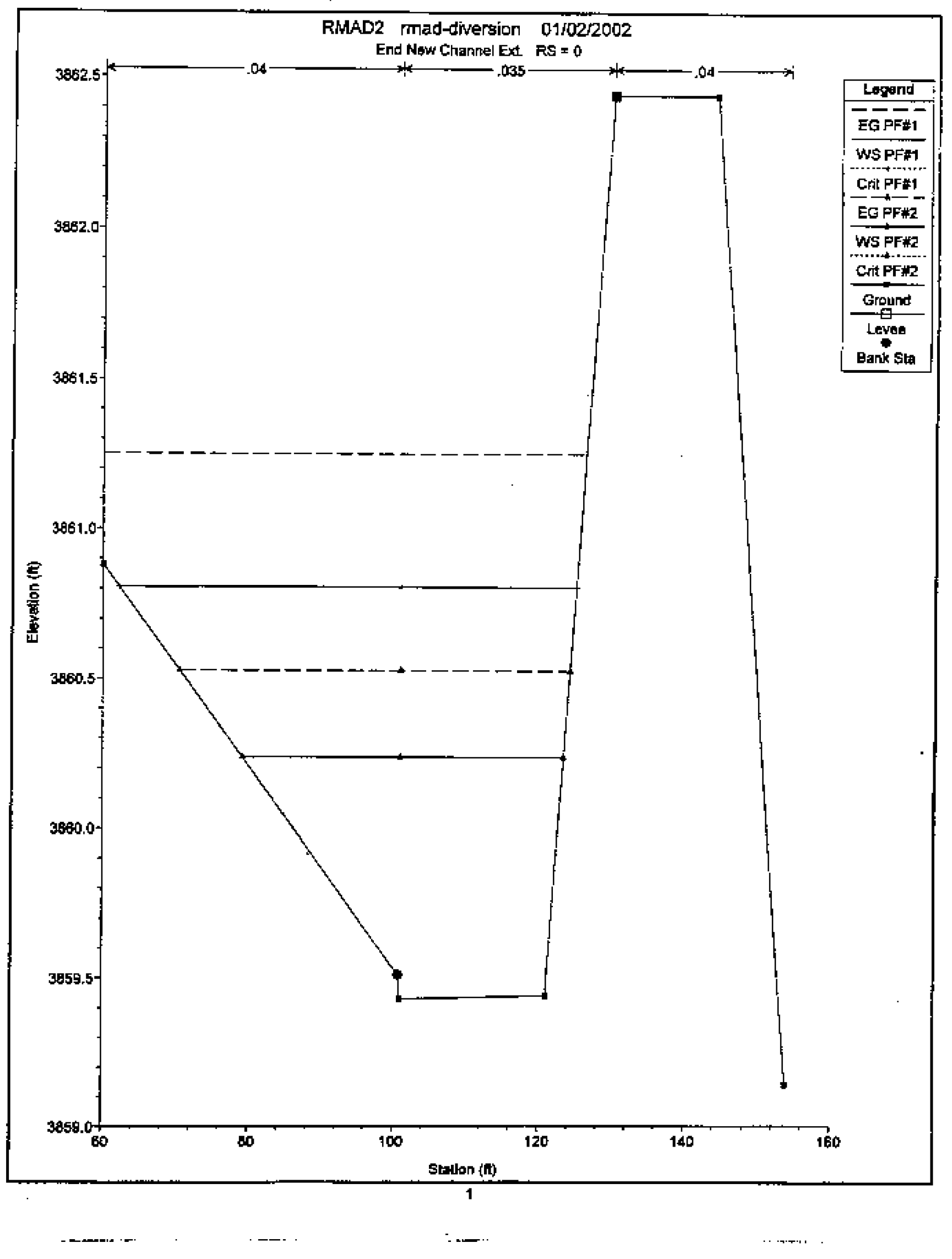


$0.175000 \mathrm{E}-01$

$0.400000 \mathrm{E}-0.1$

$3.00000 \quad 3.00000$

20.0000

$\begin{array}{llllllll}0 . & 0.00 & 0.0 & 0.0 & 0.0 & 0.0000 & 0.00\end{array}$

0. $\begin{array}{llllllll}0.00 & 0.0 & 0.0 & 0.0 & 0,0 & 0.00 & 0.08\end{array}$

$\begin{array}{llllllll}0.0 .00 & 0.0 & 0.0 & 0.0 & 0.0 & 0.00 & 0.17\end{array}$

$\begin{array}{lllllllllll}0 . & 0.00 & 0.0 & 0.0 & 0.0 & 0.0 & 0.00 & 0.25\end{array}$

$\begin{array}{lllllllll}0 . & 0.00 & 0.0 & 0.0 & 0.0 & 0.0 & 0.00 & 0.33\end{array}$

v. $\begin{array}{llllllll}0.00 & 0.0 & 0.0 & 0.0 & 0.0 & 0.00 & 0.42\end{array}$

$\begin{array}{llllllll}0 . & 0.00 & 0.0 & 0.0 & 0.0 & 0.0 & 0.00 & 0.50\end{array}$

$\begin{array}{lllllllllll}0 . & 0.00 & 0.0 & 0.0 & 0.0 & 0.0 & 0.00 & 0.58\end{array}$

$\begin{array}{llllllllll}0.0 .00 & 0.0 & 0.0 & 0.0 & 0.0 & 0.000 & 0.67\end{array}$

$\begin{array}{llllllllll}0 . & 0.00 & 0.0 & 0.0 & 0.0 & 0.0 & 0.00 & 0.75\end{array}$

$\begin{array}{llllllllll}0 . & 0.00 & 0.0 & 0.0 & 0.0 & 0.0 & 0.00 & 0.83\end{array}$

$\begin{array}{lllllllll}0 . & 0.00 & 0.0 & 0.0 & 0.0 & 0.0 & 0.00 & 0.92\end{array}$

$\begin{array}{llllllllll}0 . & 0.00 & 0.0 & 0.0 & 0.0 & 0.0 & 0.00 & 1.00\end{array}$

$\begin{array}{lllllllllllllll}0.000 & 0.0 & 0.0 & 0.0 & 0.0 & 0.00 & 1.08\end{array}$

$\begin{array}{llllllll}0 . & 0.00 & 0.0 & 0.0 & 0.0 & 0.0 & 0.00 & 1.17\end{array}$

0. $\begin{array}{cccccccc}0.00 & 0.0 & 0.0 & 0.0 & 0.0 & 0.00 & 1.25\end{array}$

$\begin{array}{lllllllll}0 . & 0.00 & 0.0 & 0.0 & 0.0 & 0.0 & 0.00 & \text { I. } 33\end{array}$

$\begin{array}{llllllll}0 . & 0.00 & 0.0 & 0.0 & 0.0 & 0.0 & 0.00 & 1.42\end{array}$

$\begin{array}{llllllll}0 . & 0.00 & 0.0 & 0.0 & 0.0 & 0.0 & 0.00 & 1.50\end{array}$

$\begin{array}{llllllll}0 . & 0.00 & 0.0 & 0.0 & 0.0 & 0.0 & 0.00 & 1.58\end{array}$

$\begin{array}{lllllllllllllll}0 . & 0.00 & 0.0 & 0.0 & 0.0 & 0.0 & 0.00 & 1.67\end{array}$

$\begin{array}{llllllll}0 . & 0.00 & 0.0 & 0.0 & 0.0 & 0.0 & 0.00 & 1.75\end{array}$

0. $\begin{array}{llllllll}0.00 & 0.0 & 0.0 & 0.0 & 0.0 & 0.00 & 1.83\end{array}$

$\begin{array}{llllllllll}0.0 .00 & 0.0 & 0.0 & 0.0 & 0.0 & 0.00 & 1.92\end{array}$

$\begin{array}{llllllll}0 . & 0.00 & 0.0 & 0.0 & 0.0 & 0.0 & 0.00 & 2.00\end{array}$

$\begin{array}{llllllll}0 . & 0.00 & 0.0 & 0.0 & 0.0 & 0.0 & 0.00 & 2.08\end{array}$

$\begin{array}{lllllllll}0 . & 0.00 & 0.0 & 0.0 & 0.0 & 0.0 & 0.00 & 2.17\end{array}$

$\begin{array}{lllllllll}0 . & 0.00 & 0.0 & 0.0 & 0.0 & 0.0 & 0.00 & 2.25\end{array}$

$\begin{array}{lllllllll}0 . & 0.00 & 0.0 & 0.0 & 0.0 & 0.0 & 0.00 & 2.33\end{array}$

$\begin{array}{llllllll}0 . & 0.00 & 0.0 & 0.0 & 0.0 & 0.0 & 0.00 & 2.42\end{array}$

$\begin{array}{lllllllll}0 . & 0.00 & 0.0 & 0.0 & 0.0 & 0.0 & 0.00 & 2.50\end{array}$

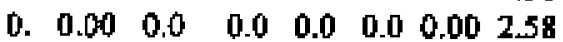

$\begin{array}{lllllllll}0 . & 0.00 & 0.0 & 0.0 & 0.0 & 0.0 & 0.00 & 2.67\end{array}$

$\begin{array}{llllllll}0 . & 0.00 & 0.0 & 0.0 & 0.0 & 0.0 & 0.00 & 2.75\end{array}$

$\begin{array}{llllllllllllll}0 . & 0.00 & 0.0 & 0.0 & 0.0 & 0.0 & 0.00 & 2.83\end{array}$

$\begin{array}{llllllll}0 . & 0.00 & 0.0 & 0.0 & 0.0 & 0.0 & 0.00 & 2.92\end{array}$

$\begin{array}{llllllll}0.0 .00 & 0.0 & 0.0 & 0.0 & 0.0 & 0.00 & 3.00\end{array}$

$\begin{array}{llllllll}0 . & 0.00 & 0.0 & 0.0 & 0.0 & 0.0 & 0.00 & 3.08\end{array}$

$\begin{array}{llllllllllll}0.0 .00 & 0.0 & 0.0 & 0.0 & 0.0 & 0.00 & 3.17\end{array}$

$\begin{array}{llllllll}0 . & 0.00 & 0.0 & 0.0 & 0.0 & 0.0 & 0.00 & 3.25\end{array}$

$\begin{array}{llllllll}0 . & 0.00 & 0.0 & 0.0 & 0.0 & 0.0 & 0.00 & 3.33\end{array}$

$\begin{array}{llllllllllllllll}0 . & 0.00 & 0.0 & 0.0 & 0.0 & 0.0 & 0.00 & 3.42\end{array}$

$\begin{array}{lllllllll}0 . & 0.00 & 0.0 & 0.0 & 0.0 & 0.0 & 0.00 & 3.50\end{array}$

l. $\begin{array}{llllllll}0.06 & 20.3 & 1.2 & 0.9 & 20.4 & 0.06 & 3.58\end{array}$

$\begin{array}{llllllll}3 . & 0.10 & 20.6 & 20 & 1.4 & 20.6 & 0.10 & 3.67\end{array}$

$\begin{array}{lllllllll}7 . & 0.18 & 21.1 & 3.7 & 1.8 & 21.1 & 0.18 & 3.75\end{array}$

14. $\begin{array}{llllllll}0.30 & 21.8 & 6.2 & 2.2 & 21.9 & 0.28 & 3.83\end{array}$

$\begin{array}{lllllllll}25 . & 0.44 & 22.5 & 9.3 & 2.7 & 22.8 & 0.41 & 3.92\end{array}$ 


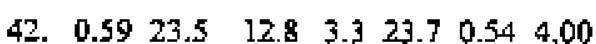

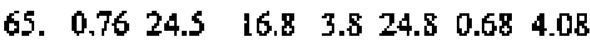
$\begin{array}{llllllll}92 . & 0.93 & 25.6 & 21.3 & 4.3 & 25.9 & 0.82 & 4.16\end{array}$

123. $1.1126 .6 \quad 25.8 \quad 4.8 \quad 27.0 \quad 0.964 .25$

156. $\quad \begin{array}{lllllll}1.27 & 27.6 & 302 & 5.2 & 28.0 & 1.08 & 4.33\end{array}$

$\begin{array}{lllllllll}18 g . & 3.41 & 28.4 & 34.1 & 5.5 & 28.9 & 1.18 & 4.41\end{array}$

$\begin{array}{llllllll}216 . & 1.52 & 29 . \mathrm{L} & 37.5 & 5.8 & 29.6 & 1.26 & 4.50\end{array}$

$\begin{array}{llllllll}239 . & 1.62 & 29.7 & 40.2 & 6.0 & 30.2 & 1.33 & 4.58\end{array}$

$\begin{array}{llllllllll}256 . & 1.68 & 30.1 & 42.1 & 6.1 & 30.6 & 1.37 & 4.66\end{array}$

$\begin{array}{llllllll}266 . & 1.72 & 30.3 & 43.2 & 6.2 & 30.9 & 1.40 & 4.75\end{array}$

270. $1.73 \quad 30.4 \quad 43.6 \quad 6.231 .0 \quad 1.41 \quad 4.83$

268. $\quad 1.73 \quad 30.4 \quad 43.4 \quad 6.2 \quad 30.9 \quad 1.41 \quad 4.91$

$\begin{array}{lllllllll}262- & 1.70 & 30.2 & 42.7 & 6.1 & 30.8 & 1.39 & 5.00\end{array}$

$\begin{array}{llllllll}253 . & 1.67 & 30.0 & 41.7 & 5.1 & 30.6 & 1.37 & 5.08\end{array}$

$\begin{array}{llllllll}241 . & 1.52 & 29.7 & 40.4 & 5.0 & 30.3 & 1.33 & 5.16\end{array}$

229. $\quad 1.5829 .5 \quad 39.0 \quad 5.9 \quad 30.0 \quad 1.30 \quad 5.25$

216. I.53 $29.2 \quad 37.5 \quad 5.8 \quad 29.7 \quad 1.26 \quad 5.33$

204. $1.4828 .9 \quad 36.1 \quad 5.729 .3 \quad 1.23 \quad 5.41$

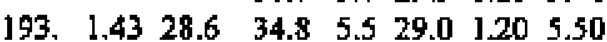

182. $1.38 \quad 28.3 \quad 33.4 \quad 5.528 .8 \quad 1.16 \quad 5.58$

173. $1.3428 .1 \quad 32.2 \quad 5.428 .5 \quad 1.13 \quad 5.66$

$\begin{array}{lllllllll}164 . & 1.30 & 27.8 & 31.2 & 5.3 & 28.2 & 1.30 & 5.75\end{array}$

157. $\quad \begin{array}{lllllll}1.27 & 27.6 & 30.2 & 5.2 & 28.0 & 1.08 & 5.83\end{array}$

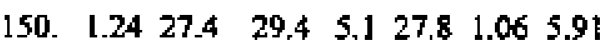

144. $1.21 \quad 27.2 \quad 28.5 \quad 5.027 .6 \quad 1.03 \quad 6.00$

138. L.L8 $27.1 \quad 27.8 \quad 5.027 .5 \quad 1.016 .08$

133. $1.16 \quad 26.9 \quad 27.1 \quad 4.927 .3 \quad 0.99 \quad 6.16$

$\begin{array}{llllllll}129 . & 1.13 & 26.8 & 26.5 & 4.9 & 27.2 & 0.98 & 6.25\end{array}$

125. $\quad 1.11 \quad 26.7 \quad 26.0 \quad 4.8 \quad 27.0 \quad 0.96 \quad 6.33$

121. $1.0926 .6 \quad 25.4 \quad 4.8 \quad 26.90 .95 \quad 6.41$

$\begin{array}{llllllll}117 . & 1.08 & 26.5 & 25.0 & 4.7 & 26.8 & 0.93 & 6.50\end{array}$

$\begin{array}{llllllll}114 . & 1.06 & 26.3 & 24.5 & 4.6 & 26.7 & 0.92 & 6.58\end{array}$

[1]. $1.04 \quad 26.2 \quad 24.1 \quad 4.626 .6 \quad 0.91 \quad 6.66$

108. $\quad \begin{array}{lllllll}1.02 & 26.1 & 23.6 & 4.6 & 26.5 & 0.89 & 6.75\end{array}$

104. $\quad 1.0026 .0 \quad 23.1 \quad 4.5 \quad 26.3 \quad 0.886 .83$

$\begin{array}{llllllll}101 . & 0.98 & 25.9 & 2.5 & 4.5 & 26.2 & 0.86 & 6.91\end{array}$

97. $\begin{array}{llllllll}0.96 & 25.8 & 21.9 & 4.4 & 26.1 & 0.84 & 7.00\end{array}$

$\begin{array}{lllllllll}92 . & 0.93 & 25.6 & 21.3 & 4.3 & 25.9 & 0.82 & 7.08\end{array}$

87. $0.90 \quad 25.4 \quad 20.5 \quad 4.3 \quad 25.7 \quad 0.80 \quad 7.16$

81. $\begin{array}{llllllll}0.87 & 25.2 & 19.7 & 4.1 & 25.5 & 0.77 & 7.25\end{array}$

75. $0.83 \quad 25.0 \quad$ l.6 $4.025 .2 \quad 0.74 \quad 7.33$

$\begin{array}{llllllll}\text { 68. } & 0.78 & 24.7 & 17.5 & 3.9 & 24.9 & 0.70 & 7.41\end{array}$

$\begin{array}{lllllllll}62 . & 0.73 & 24.4 & 16.3 & 3.8 & 24.6 & 0.66 & 7.50\end{array}$

$\begin{array}{lllllllll}\text { 55. } & 0.69 & 24.1 & 15.1 & 3.6 & 24.3 & 0.62 & 7.58\end{array}$

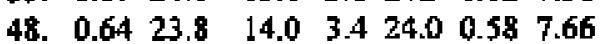

$\begin{array}{llllllll}42 . & 0.5 B & 23.5 & 12.7 & 3.3 & 23.7 & 0.54 & 7.75\end{array}$

$\begin{array}{lllllllll}36 . & 0.53 & 23.2 & 11.5 & 3.1 & 23.4 & 0.49 & 7.83\end{array}$

$\begin{array}{llllllll}31 . & 0.49 & 22.9 & 10.5 & 2.5 & 23.1 & 0.45 & 7.91\end{array}$

26. $0.45 \quad 22.7 \quad 9.6 \quad 2.8 \quad 22.8 \quad 0.42 \quad 8.00$

22. $0.4022 .4 \quad 8.5 \quad 2.6 \quad 22.5 \quad 0.38 \quad 8.09$

19. $\begin{array}{llllllll}0.36 & 22,2 & 7.6 & 2.5 & 22.3 & 0.34 & 8.16\end{array}$

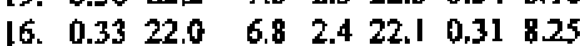

$\begin{array}{lllllllll}14 . & 0.30 & 21.8 & 6.2 & 2.2 & 21.9 & 0.26 & 8.33\end{array}$
Uppeo.txt

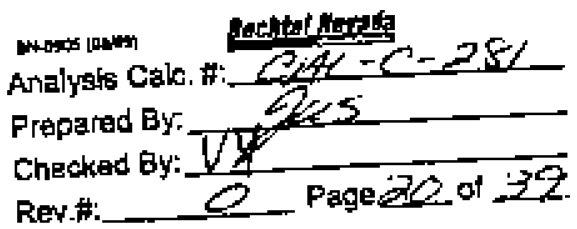



12. $\begin{array}{lllllll}0.27 & 21.6 & 5.6 & 2.1 & 21.7 & 0.26 & 8.41\end{array}$
$\begin{array}{lllllll}\text { J0. } 0.25 & 21.5 & 5.2 & 1.9 & 21.6 & 0.24 & 8.50\end{array}$
$\begin{array}{llllllll}8 . & 0.22 & 21.3 & 4.5 & 1.9 & 21.4 & 0.21 & 8.58\end{array}$
$\begin{array}{llllllll}7 . & 0.19 & 21.1 & 3.9 & 1.8 & 21.2 & 0.18 & 9.66\end{array}$
6. $0.1621 .0 \quad 3.4 \quad 3.8 \quad 21.0 \quad 0.16 \quad 8.75$
$\begin{array}{lllllllll}5 . & 0.14 & 20.9 & 3.0 & 1.7 & 20.9 & 0.14 & 8.83\end{array}$
$\begin{array}{llllllll}4 . & 0.13 & 20.8 & 2.6 & 1.6 & 20.8 & 0.13 & 8.91\end{array}$
$\begin{array}{llllllll}4 . & 0.11 & 20.7 & 2.3 & 1.6 & 20.7 & 0.11 & 9.00\end{array}$
3. $0.1020 .6 \quad 2.1 \quad 1.520 .6 \quad 0.509 .08$
3. $0.0920 .5 \quad 1.8 \quad 1.420 .60 .099 .16$

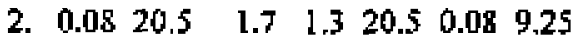

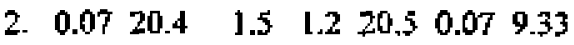

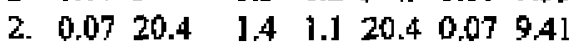
$\begin{array}{llllllll}1 . & 0.06 & 20.4 & 1.3 & 1.0 & 20.4 & 0.06 & 9.50\end{array}$
$\begin{array}{lllllll}\text { l. } 0.06 & 20.4 & 1.2 & 0.9 & 20.4 & 0.06 & 9.58\end{array}$
$\begin{array}{llllllll}1 . & 0.06 & 20.3 & 1.1 & 0.8 & 20.3 & 0.05 & 9.66\end{array}$
$\begin{array}{llllllll}1 . & 0.05 & 20.3 & 1.0 & 0.7 & 20.3 & 0.05 & 9.75\end{array}$
$\begin{array}{lllllllll}0 . & 0.00 & 0.0 & 0.0 & 0.0 & 0.0 & 0.00 & 9.83\end{array}$
$\begin{array}{llllllll}0 . & 0.00 & 0.0 & 0.0 & 0.0 & 0.0 & 0.00 & 9.9]\end{array}$

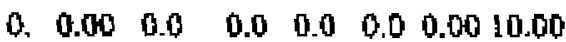
b. $\begin{array}{llllllll}0.00 & 0.0 & 0.0 & 0.0 & 0.0 & 0.00 & 10.08\end{array}$
$\begin{array}{llllllllll}0.0 .00 & 0.0 & 0.0 & 0.0 & 0.0 & 0.00 & 10.16\end{array}$
$\begin{array}{llllllllll}0 . & 0.00 & 0.0 & 0.0 & 0.0 & 0.0 & 0.00 & 10.25\end{array}$
$\begin{array}{lllllllll}0, & 0.00 & 0.0 & 0.0 & 0.0 & 0.0 & 0.00 & 10.33\end{array}$
$\begin{array}{lllllllll}\text { d. } & 0.00 & 0.0 & 0.0 & 0.0 & 0.0 & 0.00 & 10.41\end{array}$
$\begin{array}{llllllll}\text { o. } & 0.00 & 0.0 & 0.0 & 0.0 & 0.0 & 0.00 & 10.50\end{array}$

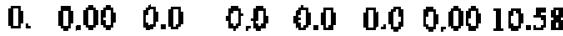
$\begin{array}{lllllllll}0 . & 0.00 & 0.0 & 0.0 & 0.0 & 0.0 & 0.00 & 10.66\end{array}$
$\begin{array}{llllllllll}0 & 0.00 & 0.0 & 0.0 & 0.0 & 0.0 & 0.00 & 10.75\end{array}$ 
IHIS COMPUTER CODE WAS DEVELOPED BY R.H. FRENCH, WATER RESOURCES CENTER, DESERT RESEARCH ENSTITUTE, LAS VEGAS, NEWADA FOR THE U.S. DEPARTMENT OF ENERGY, LAS YEGAS, NEYADA

THE DATE OF THIS YERSION IS 03/1996 AND SUPERSEDES

ALL PREVIOUS VERSIONS.

loput water temperature (deg F) 70.0

Interpolated kinementic viscosity of water (ft+2/s) 0.00001059

Interpolated fluid dersity $(5 / \mathrm{f} * 3$ *3) 1.9360

Input specific gravicy of sediment 2.55

Inpul name of filt eostaining sediment data madsize.det

Do you want 5 ummaries of the irlput dats printed? lnput I to have surmiraries printed loput 999 to have no sumbaries pristed 999

Input name of file containing hydratite data upged tht

Do you wish to make an empirical correction for cbannel shapte,

flow rate and the lack of a silt load?

Enter 1 to make this correction

Enter 999 to not make a correction 999

\section{Trapezoidal Chankel}

At this point either sedinent fall velocity dath can be input from a file or it will be computed using Rubey-5 equation. Fnter 1 to input the date froul a file or 999 to bave it computed 999

This propran has the option of adjusting the kinematic viscosity to take into aceourt the sediment (sand + gravel) Joad Input 1 to adjust the kitematic viseosity Irput 999 to not adjust the kinematic viscosity 999

Do you want detailed suminaries of the sedimett transport catculations for each time increment printed or only e sumblary? Input 1 to receive detrils 
2 osed

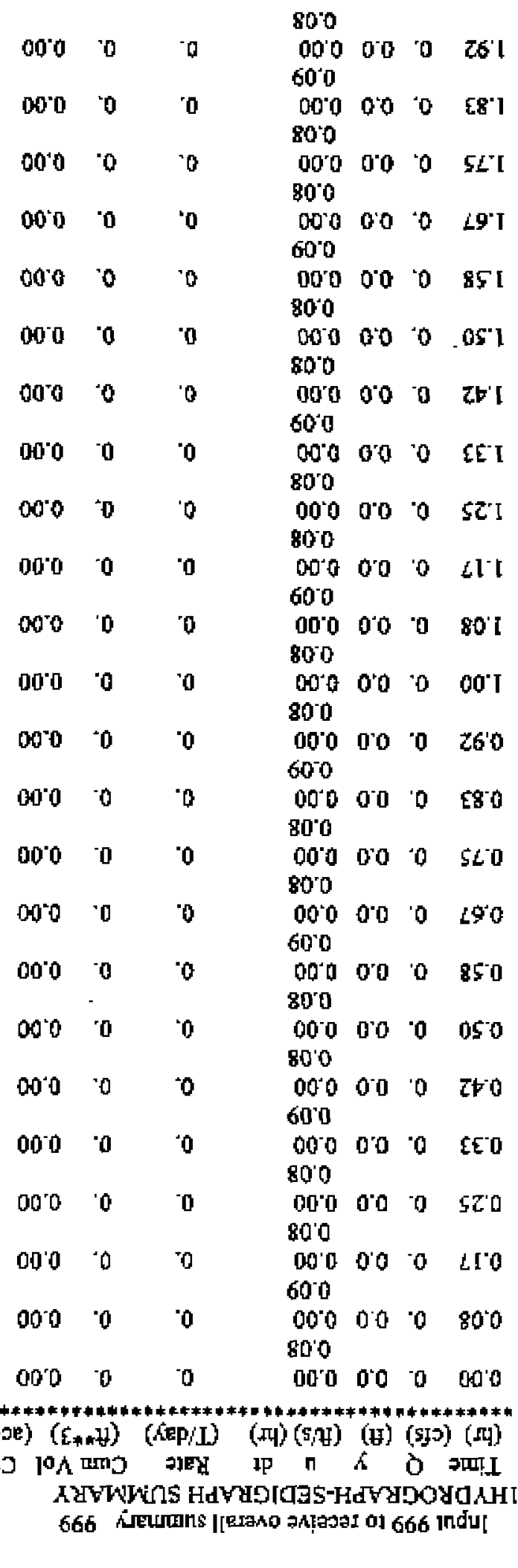




\begin{tabular}{|c|c|c|c|c|c|c|}
\hline 2.00 & 0 & 0.0 & $\begin{array}{l}0.00 \\
0.08\end{array}$ & 0. & 0. & 0.00 \\
\hline 2.08 & 0. & 0.0 & $\begin{array}{c}0.00 \\
0.09\end{array}$ & 0. & 0. & 0.00 \\
\hline 2.17 & 0 & 0.0 & $\begin{array}{l}0.00 \\
0.08\end{array}$ & 0. & 0. & 0.00 \\
\hline 225 & 0 & 0.0 & $\begin{array}{l}0.00 \\
0.08\end{array}$ & 0. & 0. & 0.00 \\
\hline 2.33 & 0 & 0.0 & $\begin{array}{c}0.00 \\
0.09\end{array}$ & 0 & 0. & 0.00 \\
\hline 2.42 & 0 & 0.0 & $\begin{array}{l}0.00 \\
0.08\end{array}$ & 0 & 0. & 0.00 \\
\hline 2.50 & 0 & 0.0 & $\begin{array}{c}0,00 \\
0,08\end{array}$ & 0. & 0. & 0.00 \\
\hline 2.58 & 0 & 0.0 & $\begin{array}{l}0.00 \\
0.09\end{array}$ & 0 & 0 & 0.00 \\
\hline 2.67 & 0. & 0.0 & $\begin{array}{l}0.00 \\
0.08\end{array}$ & 0. & 0. & 0.00 \\
\hline 2.75 & 0 & 0.0 & $\begin{array}{l}0.00 \\
0.08\end{array}$ & 0 & 0. & 0.00 \\
\hline 2.83 & 0 & 0.0 & $\begin{array}{c}0.00 \\
0.09\end{array}$ & 0 & 0 & 0.00 \\
\hline 2.92 & 0. & 0.0 & $\begin{array}{r}0.00 \\
0.08\end{array}$ & 0 & 0. & 0.00 \\
\hline 3.00 & 0. & 0.0 & $\begin{array}{c}0.00 \\
0.08\end{array}$ & 0. & 0. & 0.00 \\
\hline 3.08 & D. & 0.0 & $\begin{array}{r}0.00 \\
0.09\end{array}$ & 0. & 0. & 0.00 \\
\hline 3.17 & 0 & 0.0 & $\begin{array}{l}0.00 \\
0.08\end{array}$ & 0. & 0. & 0.00 \\
\hline 3.25 & 0. & 0.0 & $\begin{array}{c}0.00 \\
0.08\end{array}$ & 0. & 0 & 0.00 \\
\hline 3.33 & 0. & 0.0 & $\begin{array}{c}0.00 \\
0.09\end{array}$ & 0. & 0 & 0.00 \\
\hline 3.42 & 0 & 0.0 & $\begin{array}{c}0.00 \\
0.08\end{array}$ & 0. & 0. & 0.00 \\
\hline 3.50 & 0 & 0.0 & $\begin{array}{r}0.00 \\
0.08\end{array}$ & 0. & 0. & 0.00 \\
\hline 3.58 & 1. & 0.1 & $\begin{array}{c}0.90 \\
0.09\end{array}$ & 15. & 0 & 0.00 \\
\hline 3.67 & 3. & 0.1 & $\begin{array}{l}1.40 \\
0.08\end{array}$ & 93. & 3. & 0.00 \\
\hline 3.75 & 7. & 0.2 & $\begin{array}{l}\text { 1.80 } \\
0.08\end{array}$ & 295 & 11. & 0.00 \\
\hline 3.83 & 14. & 0.3 & $\begin{array}{l}2.20 \\
0.09\end{array}$ & 735 & 33. & 0.00 \\
\hline 3.92 & 25. & 0.4 & $\begin{array}{l}2.70 \\
0.08\end{array}$ & 1633 & 88. & 0.00 \\
\hline 400 & 42 & 0.6 & $\begin{array}{l}3.30 \\
0.08\end{array}$ & 3421 & 194 & 0.00 \\
\hline 4.08 & 65. & 0.8 & $\begin{array}{l}3.80 \\
0.08\end{array}$ & 6079 & 393. & 0.01 \\
\hline 4.16 & 92. & 0.9 & 4.31 & 9696. & 724 & 0.02 \\
\hline
\end{tabular}


Upsed2 $+x t$

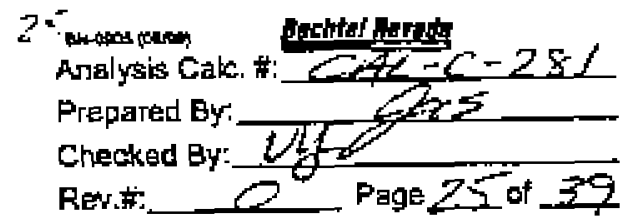

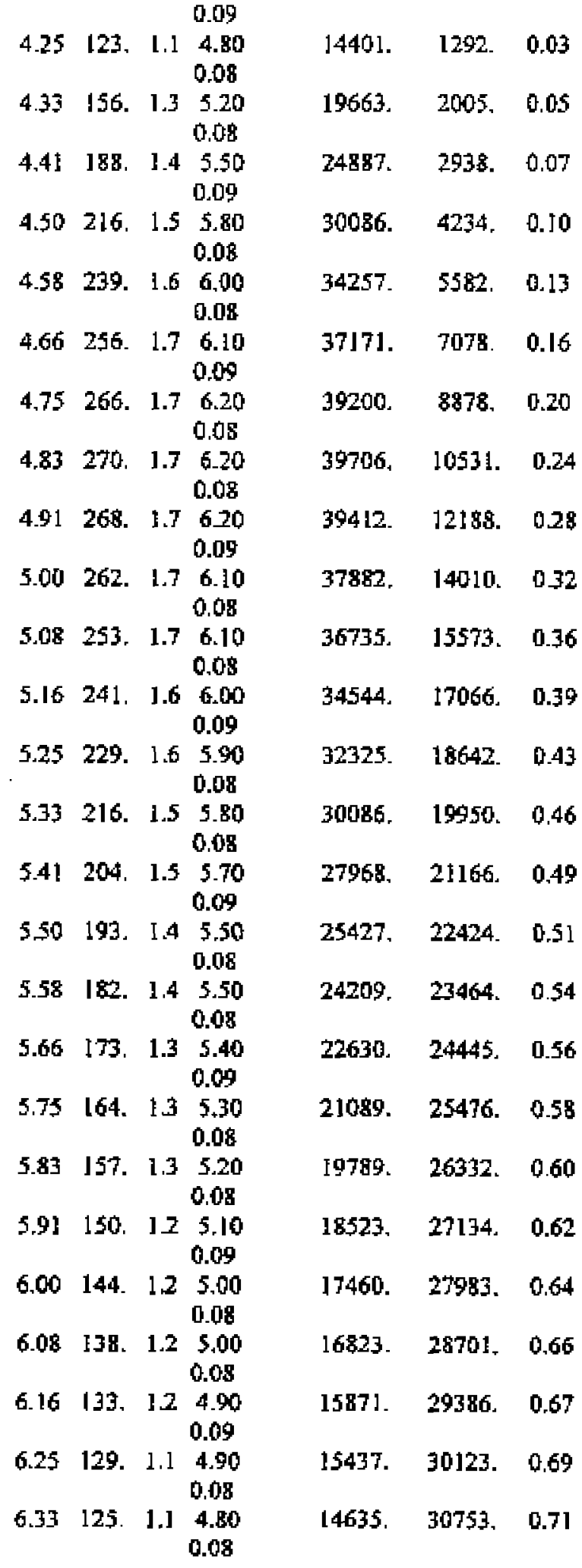




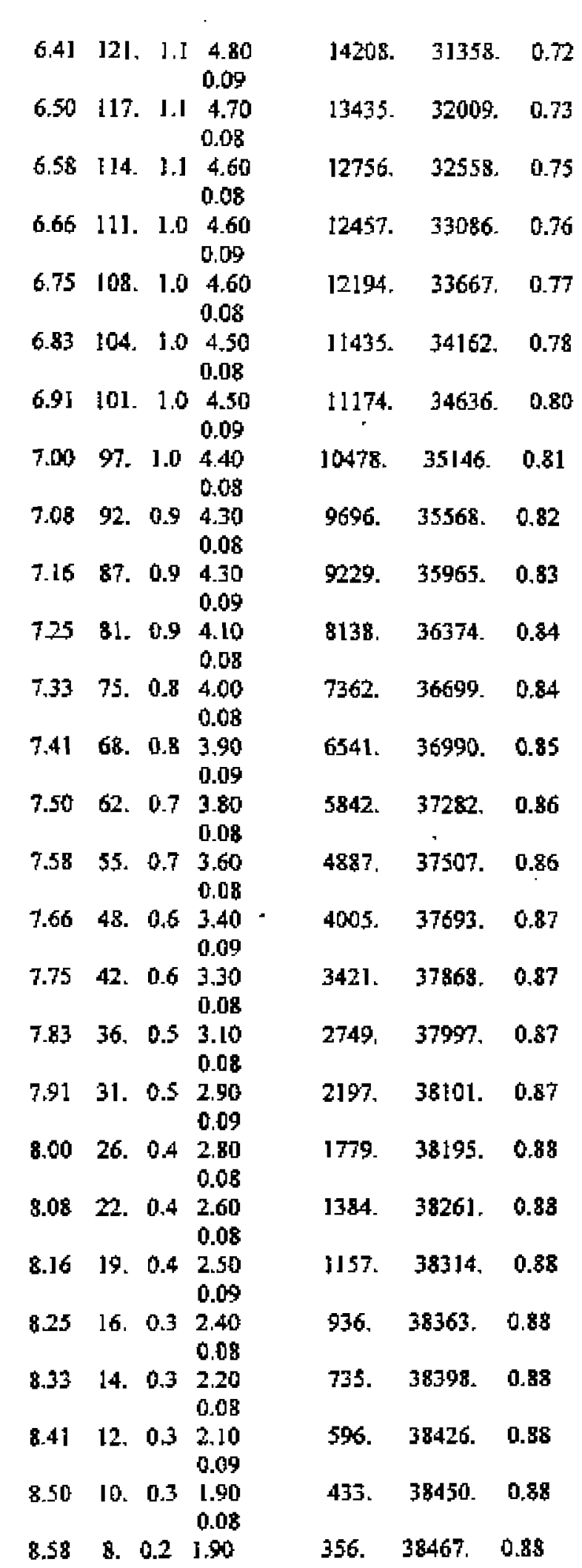


295. $\quad 38481 . \quad 0.88$

259. 38494. 0.88

202. 38503.

148. 38511.0 .98

153. 39518.0 .88

105. 38523. 0.88

95. $\quad 38527 . \quad 0.89$

57. 38531. 0.89

50. $38533-0.88$

43. 38535, 0.88

18. $\quad 38536 . \quad 0.88$

15. 38537. 0.88

12. 38538.0 .88

9. $38538,0.88$

0. 38538. 0.88

0. 38538. 0.88

0. $38538,0.88$

0. $\quad 38538,0.88$

0. $\quad 38538 . \quad 0.88$

0. 39578 0.88

0. $38538, \quad 0.88$

0. 38538. 0.88

0. $38538 . \quad 0.88$

0. 39538.0 .88

0. 38538.0 .88

0. $38538,0.88$ 


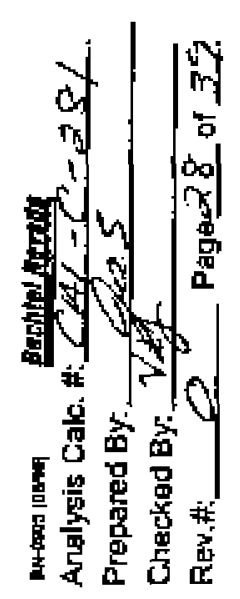

W

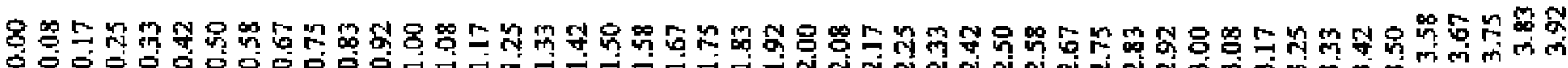
\%

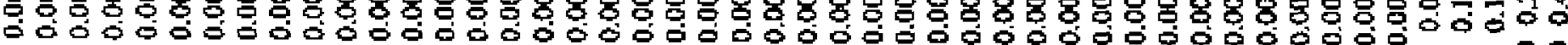

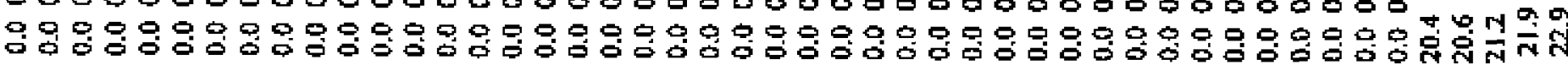
$0000000000000000000000000000000000000000000014 N$ N

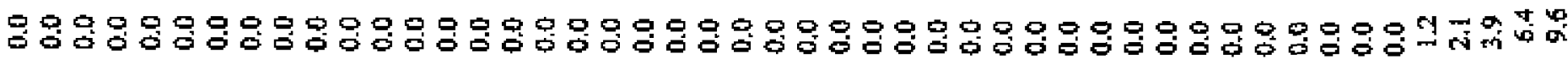
5

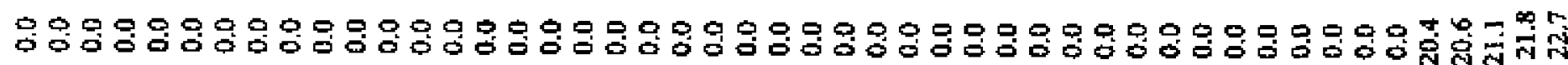

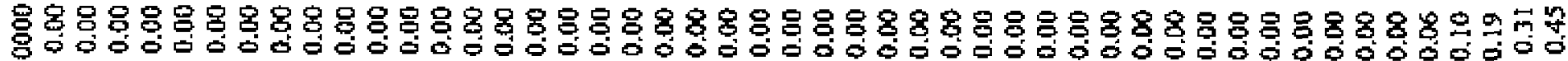

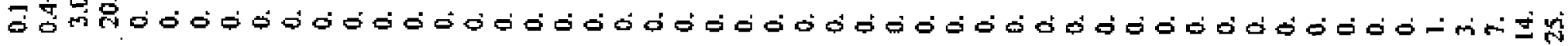


4.08

92. $0.96 \quad 258 \quad 220 \quad 472610.844 .16$

I56. $1.30278 \quad 3125.028 .2 \quad 1.104 .33$

188. $1.4528 .7 \quad 35.3 \quad 5.329 .2 \quad 1.214 .41$

216. $\quad 1.57 \quad 29.4 \quad 38.8 \quad 5.62991 .304 .50$

5.730 .51 .364 .58

$266 . \quad 1.7730 .6 \quad 447 \quad 6031.21 .434 .75$

270. $1.78 \quad 30.7 \quad 45.2 \quad 6.0 \quad 313 \quad 1.44 \quad 4.83$

$\begin{array}{llllll}4.0 & 31.2 & 1.44 & 4.91\end{array}$

425.00

1.335 .25

.305 .33

193. $1.4728 .8 \quad 360 \quad 5.42931235 .50$

182. $1.4328 .6 \quad 34.6 \quad 53290 \quad 1.195 .58$

173. 1.J8 28.3 39.45 .228 .71 .165 .66

$157 \quad 13127801250205111583$

150. $1.27 \quad 27.6 \quad 30.4 \quad 4.928 .1 \quad 1.085 .91$

144. $1.25 \quad 27.5 \quad 29.6 \quad 4.927 .9 \quad 1.06 \quad 6.00$

$\begin{array}{llllllll}138 . & 1.22 & 27.3 & 28.8 & 4.8 & 27.7 & 1.04 & 6.08\end{array}$

133. 1.1927 .12814 .727 .51 .026 .16

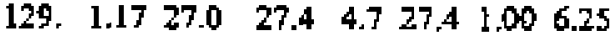

125. 1.1426 .9 26.8 $4.627 .420 .98 \quad 6.33$

$\begin{array}{llllllll}121 . & 1.12 & 26.7 & 263 & 4.6 & 27.1 & 0.97 & 6.41\end{array}$

$\begin{array}{llllllll}117 . & 1.11 & 26.6 & 25.8 & 4.5 & 27.0 & 0.96 & 6.50 \\ 114 & 1.09 & 26.5 & 25.9 & 4.5 & 26.9 & 0.94 & 6.58\end{array}$

1] $1 . \quad 1.0726 .4 \quad 24.9 \quad 4.5 \quad 26.80 .93 \quad 6.66$

108. $\begin{array}{lllllll}1.05 & 26.3 & 24.4 & 4.4 & 26.7 & 0.92 & 6.75\end{array}$

104. I.03 $26.2 \quad 23.9 \quad 4.426 .5 \quad 0.906 .83$

101, $1.01 \quad 26.1 \quad 23.3 \quad 4.3 \quad 26.4 \quad 0.886 .91$

9. 0.9925 .922 .74326 .3 0.87 7.00

870.9325 .621 .4112590 .827 .16

$\begin{array}{lllllllll}81 . & 0.89 & 25.4 & 20.3 & 4.0 & 25.7 & 0.79 & 7.25\end{array}$

75. $\quad \begin{array}{llllllll}0.86 & 25.1 & 19.3 & 3.9 & 25.4 & 0.76 & 7.33\end{array}$

$\begin{array}{llllllll}68 . & 0.81 & 24.8 & 18.1 & 3.8 & 25.1 & 0.72 & 7.41\end{array}$

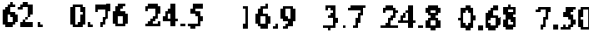

55. $\quad 0.71 \quad 24.2 \quad 15.6 \quad 3.524 .5 \quad 0.64 \quad 7.58$

$\begin{array}{llllllll}4.8 . & 9.66 & 23.9 & 14.5 & 3.3 & 24.2 & 0.60 & 7.6 .6\end{array}$

42. $0.60 \begin{array}{lllllll}23.6 & 13.7 & 3.2 & 23.8 & 0.55 & 7.75\end{array}$

36. 0.55233

31. 0.5023 .0 10.8 2.923 .20 .477 .91

26. $\begin{array}{lllllll}0.46 & 22.8 & 9.9 & 2.7 & 22.9 & 0.43 & 8.00\end{array}$

$\begin{array}{lllllllll}22 . & 0.42 & 22.5 & 0.8 & 2.5 & 22.6 & 0.39 & 8.08 \\ 19 . & 0.37 & 22 & 7 . & 2.4 & 22.4 & 0.35 & 8.16\end{array}$

$\begin{array}{lllllllll}16 . & 0.34 & 22.0 & 7.1 & 2.3 & 22.1 & 0.32 & 8.25\end{array}$

$\begin{array}{llllllll}14 . & 0.30 & 21.8 & 6.4 & 2.1 & 21.9 & 0.29 & 8.33\end{array}$
REv_\#. Page 27 of 37 
[2. $\begin{array}{llllllll}0.28 & 21.7 & 5.8 & 2.0 & 21.8 & 0.27 & 8.41\end{array}$

]0. $0.2621 .5 \quad 5.3 \quad 1.8 \quad 21.6 \quad 0.25 \quad 8.50$

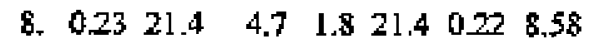

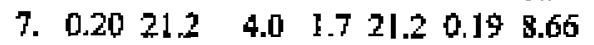

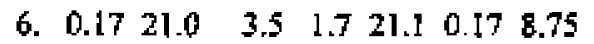

5. $0.15 \quad 20.9 \quad 3.1 \quad 1.6 \quad 21.0 \quad 0.15 \quad 8.83$

4. $0.1320 .8 \quad 2.7 \quad 1.6 \quad 20.80 .13 \quad 8.91$

4. $0.12 \quad 20.7 \quad 2.4 \quad 1.5 \quad 20.7 \quad 0.12 \quad 9.00$

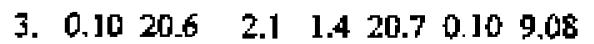

3. $0.0920 .6 \quad 1.9 \quad 1320.6 \quad 0.09 \quad 9.15$

2. $0.0820 .5 \quad 1.7 \quad 1320.50 .089 .25$

$\begin{array}{llllllll}2 . & 0.08 & 20.5 & 1.6 & 1.2 & 20.5 & 0.05 & 9.33\end{array}$

2. $0.07 \quad 20.4 \quad 1.4 \quad 1.1 \quad 20.4 \quad 0.07 \quad 9.41$

I. $0.0620 .4 \quad 1.3 \quad 1.0 \quad 20.4 \quad 0.06 \quad 9.50$

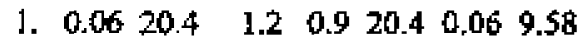

1. $0.06 \quad 20.3 \quad 1.1 \quad 0.8 \quad 20.4 \quad 0.06 \quad 9.66$

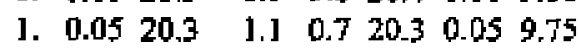

$\begin{array}{llllllll}0 . & 0.00 & 0.0 & 0.0 & 0.0 & 0.0 & 0.00 & 9.83\end{array}$

o. $\begin{array}{llllllll}0.00 & 0.0 & 0.0 & 0.0 & 0.0 & 0.00 & 9.91\end{array}$

$\begin{array}{llllllllll}0 . & 0.00 & 0.0 & 0.0 & 0.0 & 0.0 & 0.00 & 10.00\end{array}$

o. $\begin{array}{ccccccc}0.00 & 0.0 & 0.0 & 0.0 & 0.0 & 0.00 & 10.08\end{array}$

$\begin{array}{llllllll}0 . & 0.00 & 0.0 & 0.0 & 0.0 & 0.0 & 0.00 & 10.16\end{array}$

$\begin{array}{llllllll}0 . & 0.00 & 0.0 & 0.0 & 0.0 & 0.0 & 0.00 & 1025\end{array}$

$\begin{array}{llllllll}0 . & 0.00 & 0.0 & 0.0 & 0.0 & 0.0 & 0.00 & 10.33\end{array}$

$\begin{array}{llllllll}0 . & 0.00 & 0.0 & 0.0 & 0.0 & 0.0 & 0.00 & 10.41\end{array}$

$\begin{array}{llllllll}0 . & 0.00 & 0.0 & 0.0 & 0.0 & 0.0 & 0.00 & 10.50\end{array}$

$\begin{array}{llllllll}0 . & 0.00 & 0.0 & 0.0 & 0.0 & 0.0 & 0.00 & 10.58\end{array}$

$\begin{array}{llllllll}0 . & 0.00 & 0.0 & 0.0 & 0.0 & 0.0 & 0.00 & 10.66\end{array}$

o. $0.00 \quad 0.0 \quad 0.0 \quad 0.0 \quad 0.00 .0010 .75$ 
Drsed2tat

THIS COMPUTER CODE WAS DEWELOPED BY RH. FRETICH, WATER RESOURCES CENTER, DESERT RESEARCH NSTITUTE, LAS VEGAS, NEVADA FOR THE U.S. DEPARTMENT OF ENERGY, LAS VEGAS, NEVADA.

\section{THE DATE OF THIS VERSION 15 03/1996 AND SUPERSEDES} ALL PREVIOUS VERSIONS.

Eput water temptrahire (deg F) 70.0

Intepolated kinematic viseosity of water $\left(\mathrm{ft}^{+}-2 / \mathrm{s}\right) \quad 0.00001059$

Lnterpolated fludd density (sLft**3) I.9360

Input specific gravity of sediment 2.55

Input name of fule containing sediment data madsize_dat

Do you want summaries of the input data printed? Input 1 to have summaries printed lnput 999 to have no summaries printed 999

Input name of file containirg hydraulic data dngeo.tat

Do you wish to make an empirifal correction for chayriel shape, flow rate and the lack of a silt load?

Enter I to make this eorrection

Enter 999 to bot rake seorrection 999

Traptezoidal Charuel

At this point either sedirnent fell relocity data can be input from a file or it will be computed using Rubey-s equation. Enter 1 to fifput the data from a file or 999 to bave it conputed 999

This program bas the option of adjusting the kinemtatic viscosity to take into arcount the sediment (sand + eravel) toad Inpust 1 to adjust the kinematic viscosjty lnput 999 to not adjust the kinemetic viscosity gog

Do you want detatled sminaries of the sediment transport caleulations for each time increment printed or only a simmmary? Input 1 to neceive decails 


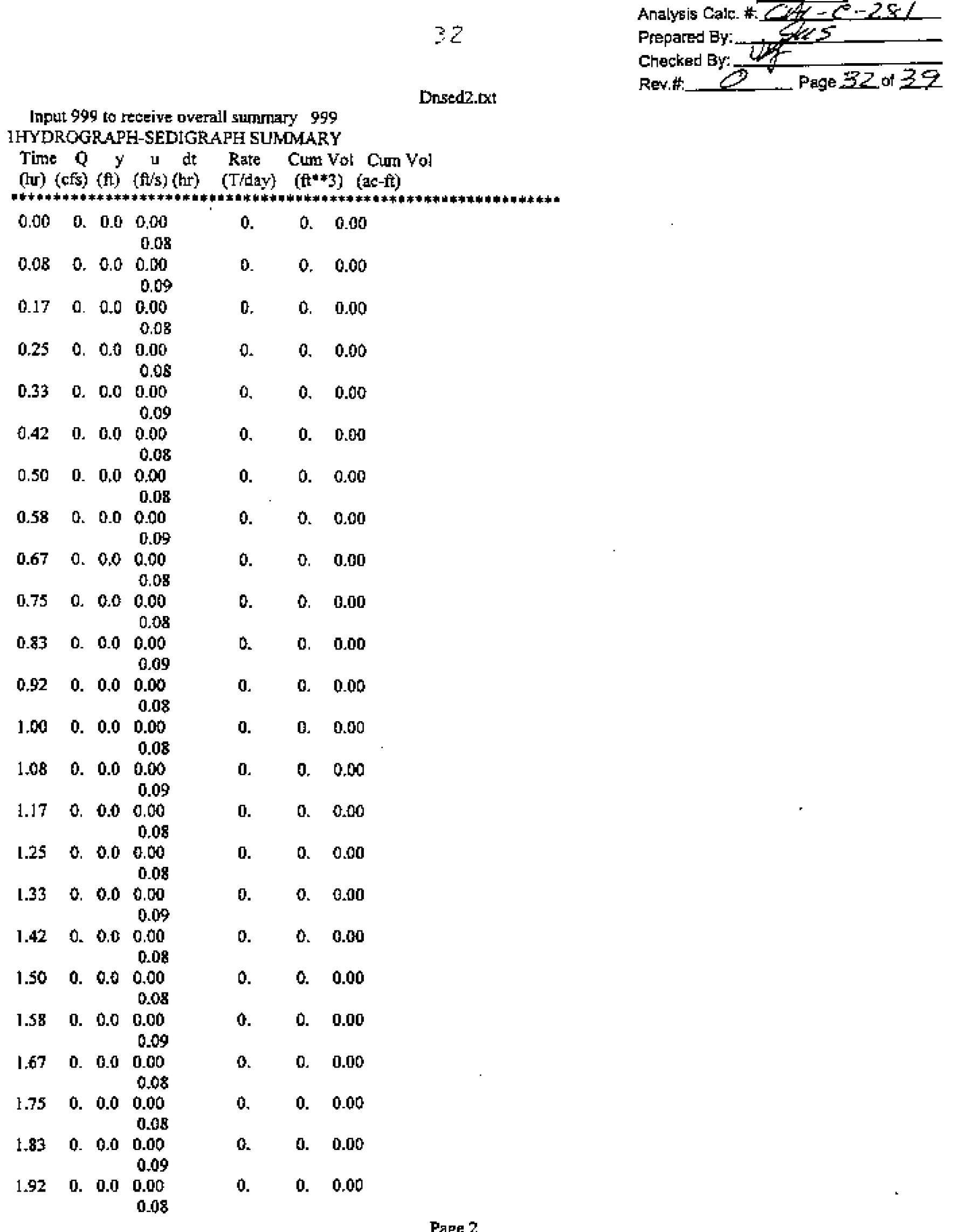




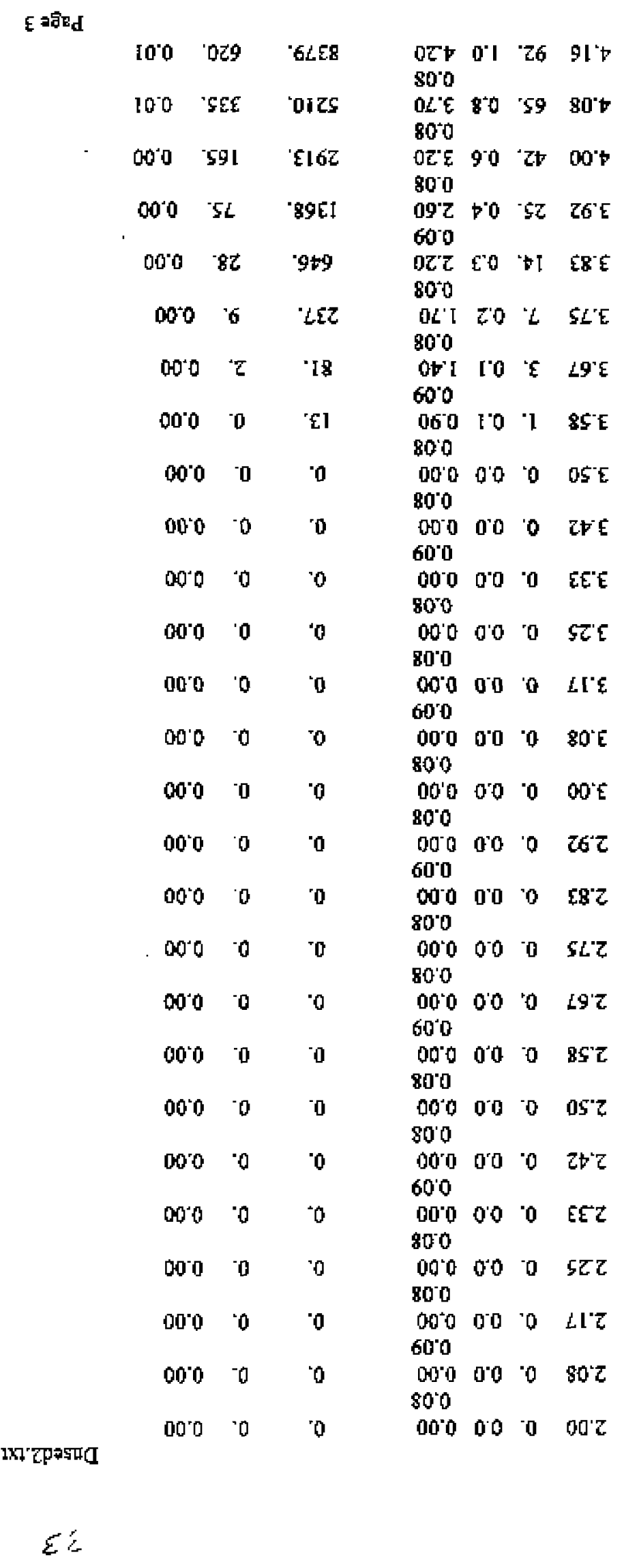


$\begin{array}{lllllll}4.25 & 123 & 1.1 & 4.60 & 12168 . & 1104 . & 0.03\end{array}$

$4.33156 .1 .35 .00 \quad 16727 . \quad 1709.0 .04$

4.4J $188 . \quad 1.55 .30 \quad 21220 . \quad 2504.0 .06$

$4.50216,1.65 .60 \quad 25700 . \quad 3610.0 .08$

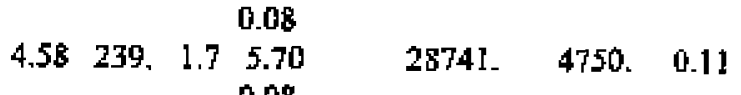

4.66 255. $1.75 .90 \quad 31981 . \quad 6020.0 .14$

$\begin{array}{lllllll}4.75 & 266 . & 1.8 & 6.09 & & & \\ & 63727 . & 7566 . & 0.17\end{array}$

$\begin{array}{lllllll}4.83 & 270 . & 1.8 & 6.00 & 34167 . & 8989 & 0.21\end{array}$

$\begin{array}{lllllll}4.91 & 268 . & 1.8 & 6.00 & 33914 . & 10415 . & 0.24\end{array}$

$\begin{array}{lllllll}5.00 & 262 . & 1.8 & 5.90 & 32564 . & 11582 . & 0.28\end{array}$

$5.08253 .1 .75 .90 \quad 31571 . \quad 13325.0 .31$

5.16 241. $1.7 \begin{array}{ccccc}0.08 & 50 & 29588 . & 14606 . & 0.34\end{array}$

$5.25279 .1 .65 .70 \quad 27710.09015957 .037$

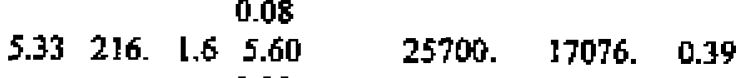

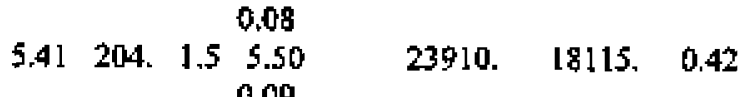

$\begin{array}{lllllll}5.50 & 193 & 1.5 & 5.40 & 22228 . & 19202 & 0.44\end{array}$

$\begin{array}{ccccccc}5.58 & 182 . & 1.4 & 5.30 & & & \\ & 5.30 & 20636 . & 20100 & 0.46\end{array}$

$\begin{array}{lllllll}5.66 & 173 & 1.4 & 5.20 & 19262 . & 20936 . & 0.48\end{array}$

$\begin{array}{lllllll}5.75 & 164 . & 135.09 & 5.10 & 17923 . & 21812 . & 0.50\end{array}$

$5.83157 .1 .35 .00 \quad 16794 . \quad 22539.0 .52$

5.91 150. $13 \begin{array}{ccccc}0.08 & 4.90 & 15735 . & 23221 . & 0.53\end{array}$

$6.00 \quad 144.1 .34 .90 \quad 15181,23950.0 .55$

$\begin{array}{lllllll}6.08 & 138 . & 1.2 & 4.80 & 14226 . & 24566 . & 0.56\end{array}$

$\begin{array}{lllllll}6.16 & 133 . & 12 & 0.08 & & & \\ 6.70 & 13400 . & 25144 . & 0.58\end{array}$

$6.25129 .1 .2 \begin{array}{ccccc}0.09 & & & & \\ 6.70 & 13065 & 25769 . & 0.59\end{array}$

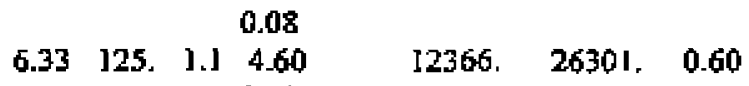
0.08 


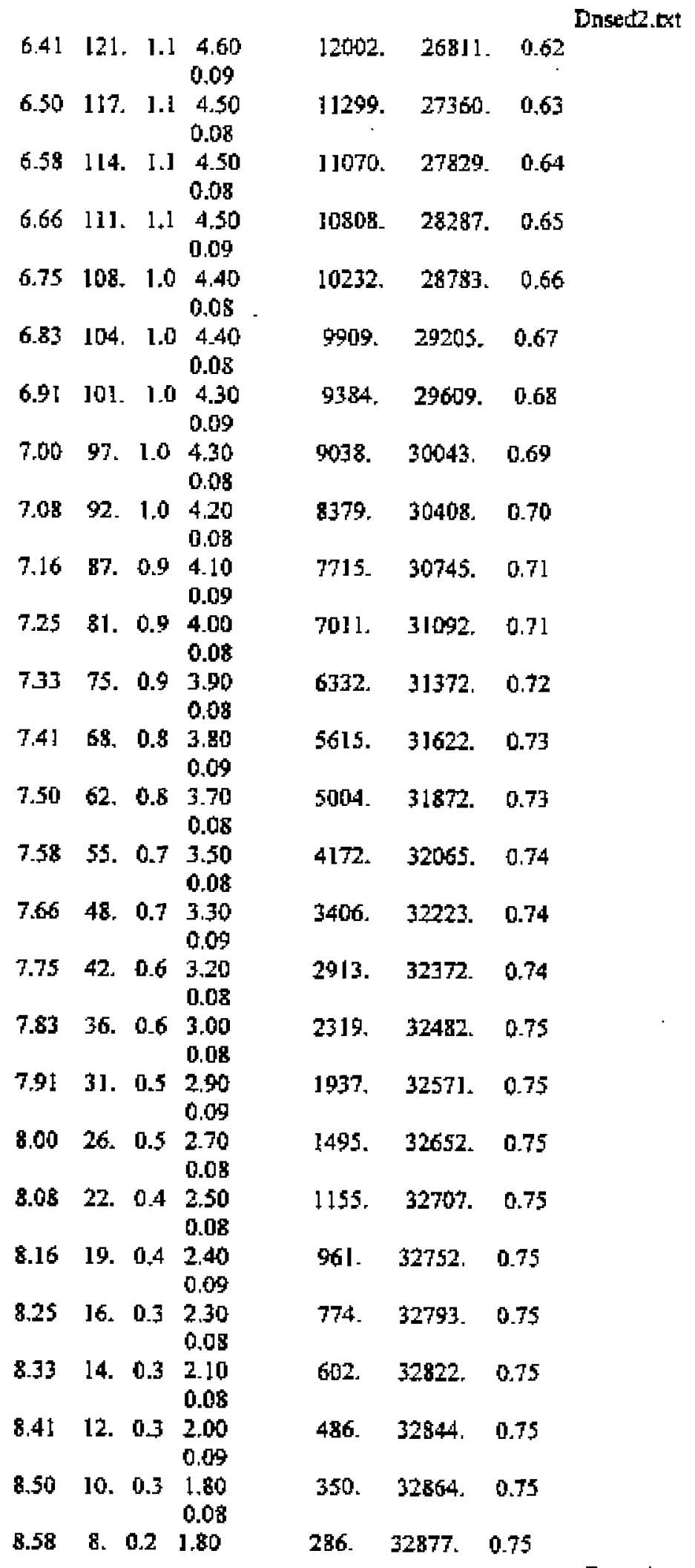


36

Dnsed2.txt

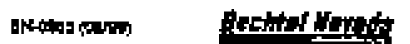

Analysis Calo, \#, $Q \angle C-\angle-29$ Prepared By:

Checked Bys.

Rev.\#
$\begin{array}{llll}8.66 & 7 . & 0.2 & 1.70\end{array}$
235. $\quad 32888 . \quad 0.76$
$\begin{array}{llll}8.75 & 6 . & 0.2 & 1.70\end{array}$
206. 32899. 0.76
8.83 5. $0.2 \quad 1.60$
159. 32906. 0.76
8.91 4. $0.1 \quad 1.60$
130. 32912. 0.76
$\begin{array}{llll}9.00 & 4 . & 0.1 & 1.50\end{array}$
0.08
119. 32918. 0.76
$\begin{array}{llll}9.08 & 3 . & 0.1 & 1.40\end{array}$
0.08
$\begin{array}{llll}9.16 & 3 . & 0.1 & 1.30\end{array}$
81. 32922, $\quad 0.76$
73. $32926, \quad 0.76$
$\begin{array}{llll}9.25 & 2 & 0.1 & 1.30\end{array}$
49. 32929. 0.76
$\begin{array}{llll}9.33 & 2 . & 0.1 & 1.20\end{array}$
43. $52930 . \quad 0.76$
$\begin{array}{lllll}9.41 & 2 . & 0.1 & 1.10\end{array}$
0.09
$9.50 \quad 1.0 .1 \quad 1.00$
37. $32932 \quad 0.76$
16. 32933, 0.76
$\begin{array}{lllll}9.58 & 1 & 0.1 & 0.90\end{array}$
0.08
$\begin{array}{llll}9.66 & 1 . & 0.1 & 0.80\end{array}$
13. $32934,0.76$
10. \$2934. 0.76
$\begin{array}{llll}9.75 & \text { 1. } & 0.1 & 0.70\end{array}$
0.08
$\begin{array}{llll}9.83 & 0.0 .0 & 0.00\end{array}$
8. $\quad 32935-0,76$
o. 32935. 0.76
$\begin{array}{llll}9.91 & 0 . & 0.0 & 0.00\end{array}$
$10.00 \quad 0.0 .0 \quad 0.00$
0. $32935 . \quad 0.76$
0. 32935. 0.76
$\begin{array}{llll}10.08 & 0, & 0.0 & 0.00\end{array}$
o. 32935. 0.76
$10.16 \quad 0, \quad 0.0 \quad 0.00$
0. 32935. 0.76
$10.25 \quad 0.000,00$
0. 32995. 0.76
$10.33 \quad 0.0 .0 \quad 0.00$
0. 32935. 0.76
$10.410 .0 .0 \quad 0.00$
o. 32935. 0.76
$\begin{array}{llll}10.50 & 0 . & 0.0 & 0.00\end{array}$
0. 32935. 0.76
$\begin{array}{llll}10.58 & 0 & 0.0 & 0.00\end{array}$
0. $32935 . \quad 0.76$
$\begin{array}{llll}10.66 & 0 . & 0.0 & 0.00\end{array}$
0. 32935. 0.76
$10.75 \quad 0,0.0 \quad 0.00$
0. 32995. 0.76 
THIS COMPUTER CODE WAS ORIGTNALLY DEVELOPED BY

R.H. FRENCH, HYDRAULIC \& HYDROLOGIC CONSILTRNG

ENGINEER FOR THE CLARK COUNTY (NEVADA) REGIONAL

FLOOD CONTKOL DISTRICT, THE CITY OF NORTH LAS

(NEVADA) AND THE CITY OF HENDERSON (NEVADA).

THIS VERSION WAS DEVELOPED BY R.H. FRENYCH,

WATER RESOURCES CENTER, DESERT RESEARCH NNSTITUTE

LAS VEGAS, NEYADA FOR THE U.S. DEPARTMENT OF

ENERGY, LAS VEGAS, NEVADA.

THE DATE OF THIS VERSION IS I1/1995 AND SUPERSEDES

ALL PREVIOUS VERSIONS

\section{SLOPE TRANSITION DEPOSITION (SCOUR) PROGRAM}

Input the volume of sediment to be deposited (scoured) in acre-feet 0.12

loput width of upstream chantil $\mathbf{5 0}$.

Input width of dowastrean ehannel 47.

Irput signed slope of upstream channel -0.01750

Input signed stope of dowrstream channel -0.01580

Irput elewation of hinge point $\mathbf{3 0 0 . 0 0}$

Input trial length over which deposition (seari) pecurs 2000.0

SEDIMENT VOLUME TO BE DEPOSITED (SCOURED) - 0.12 aere-feet

SEDMIENT VOLIJME DEPOSITED (SCOURED) $=0.32$ acre-fet

BED SURFACE ELEVATION AT HNGE POINT $=300.42 \mathrm{ft}$

MAXIMUM DEPTH OF DEPOSITION (SCOUR) $=0.43 \mathrm{At}$

Input a non-zero trial length ower which deposititan (scour) occurs is coptinue. 1000 Ittput zero to stop.

SEDLMENT VOLUME TO BE DEPOSITED (SCOURED) - 0.12acre-fet SEDDENT YOLLME DEPOSITED (SCOURED) - 0.08 acTe-fEt

BEO SURFACE ELEVATION AT HINGE POINT $=300.21 \mathrm{ft}$

MAXIMUM DEPTH OF DEPOSITION (SCOUR) $=0.21 \mathrm{ft}$

Page 1 
Tramsum2.txt

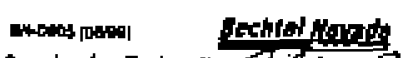

Analysis Cetc. \#.CAL-C=?

Preparad Ey:

Chepked By.

Rew.\# 425

Input a non-zero trial length over which deposition (seour) occurs to continue. 1500 Input zero to stop.

SEDIMENT VOLUME TO BE DEPOSITED (SCOURED) $=0.12$ aere-feet SEDIMENT YOLUME DEPOSITED (SCOURED) $=0.18$ acre-feet BED SURFACE ELEVATION AT HINGE POINT $=300.32 \mathrm{ft}$ MAXIMUM DEPTH OF DEPOSITION (SCOUR) = $0.32 \mathrm{ft}$

Input a non-zero trial length over which deposition (steur) occurs to continue. 1400 linput zero to stop.

SEDMMENT VOLUME TO BE DEPOSITED (SCOURED) - 0.12atre-fet SEDIMENT VOLUME DEPOSITED (SCOURED) = 0.15 acre-feet BED SURFACE ELEVATION AT HINGE POINT $=300.30 \mathrm{ft}$ MAXIMUM DEPTH OF DEPOSITION (SCOUR) $=0.30 \mathrm{ft}$

Irput a nod-zere trial leagth over which deposition (sceln) occurs to continge. 1300 Input zero to stop.

SEDIMENT VOLUME TO BE DEPOSITED (SCOURED) = 0.12atre-fet SEDTMENT VOLUME DEPOSITED (SCOURED) = 0.13 acte-feet BED SURFACE ELEVATION AT HINGE POINT $=300.28 \mathrm{ft}$ MAXIMUM DEPTH OF DEPOSITION (SCOLR $)=0.28 \mathrm{ft}$

Jnput a nom-zero trjal leggth over which deposition (seour) occurs to continue. 1200 input zero to stop.

SEDIMENT VOLUME TO BE DEPOSFTED (SCOURED) - 0.12akTe-feet SEDIMENT WOLUME DEPOSITED (SCOURED) $=0.11$ acre-feet BED SUIRFACE ELEVATION AT HINGE POINT $=300.26 \mathrm{ft}$ MAXIMUM DEPTH OF DEPOSITION (SCOUR) $=0.26 \mathrm{ft}$

Input a non-zeto trial length aver which deposition (scour) ocears to continue. 1250 Input zero to stop.

SEDTMENT VOLUME TO BE DEPOSITED (SCOURED) - 0.12acre-feet SEDMENT VOLUME DEPOS1TED (SCOURED) $=0.12$ acte-fet

Page 2 
Transum2.xt

BED SURFACE ELEVATION AT HTNGE POINT $=300.27 \mathrm{ft}$ MAXIMUM DEPTH OF DEPOSITION (SCOUR) $=0.27 \mathrm{ft}$

Input a non-zero tial length ower whidh deposition (scout) occurs to continue 0 Input zero to stop. 


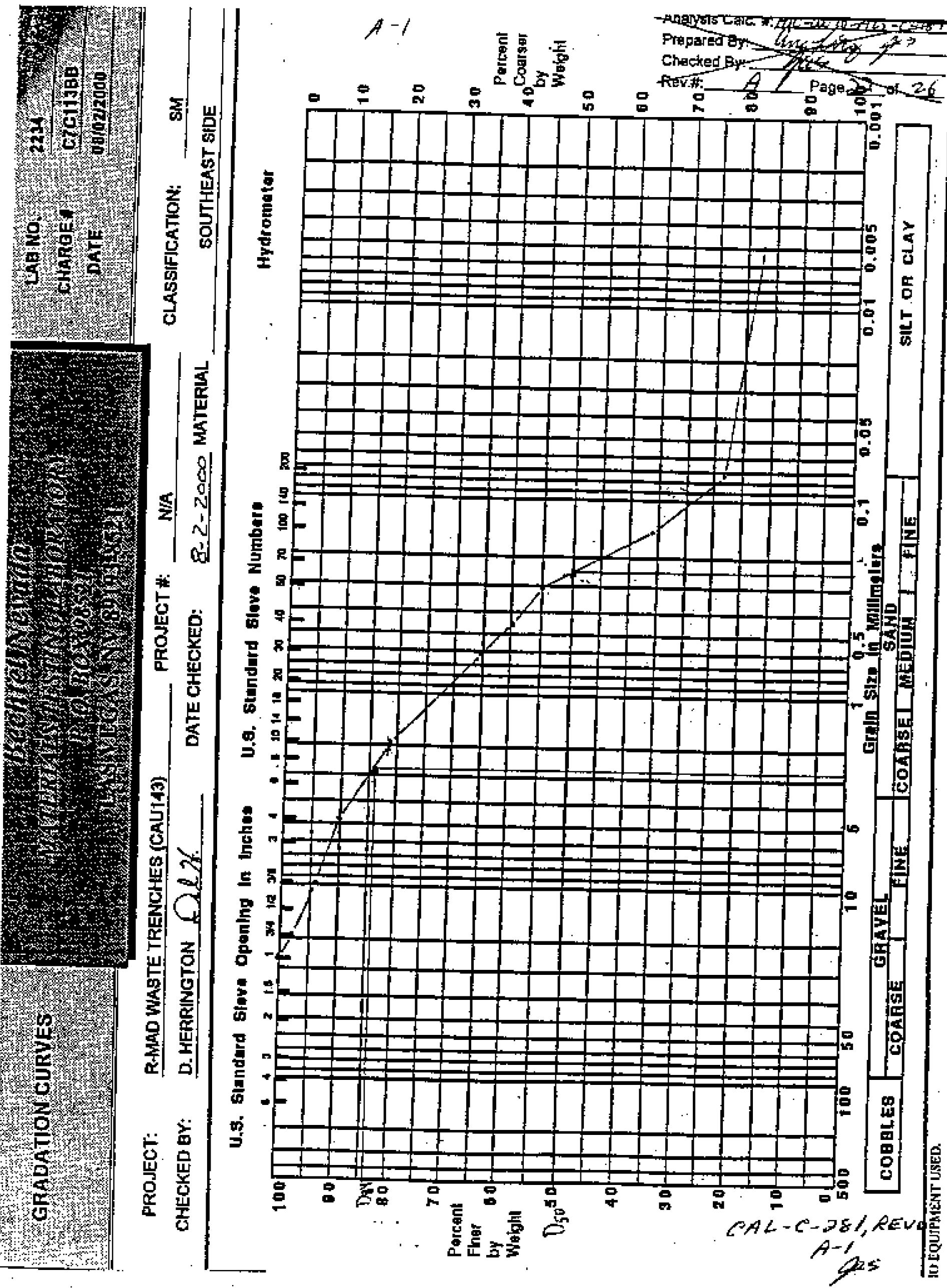



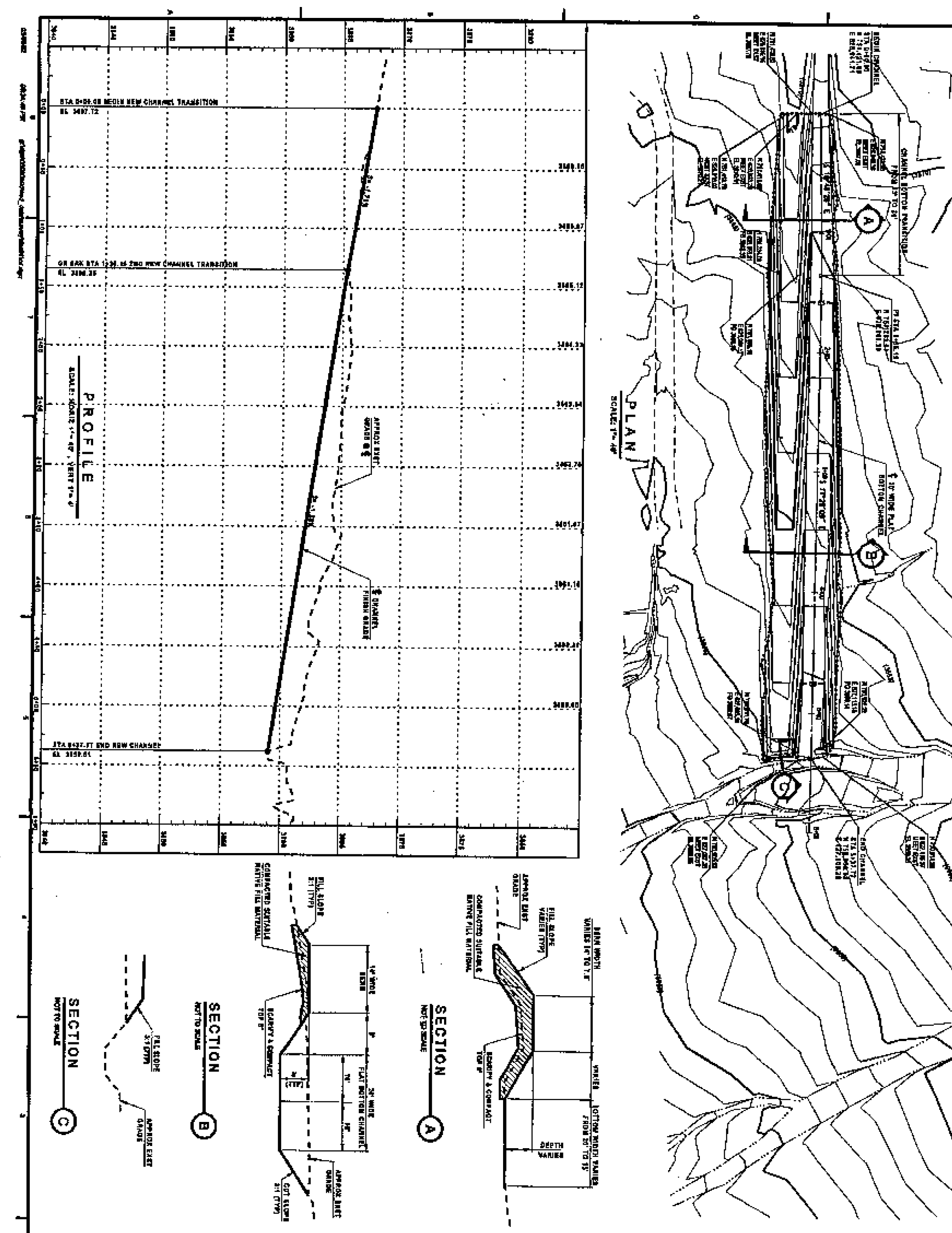

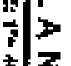

$\nabla$
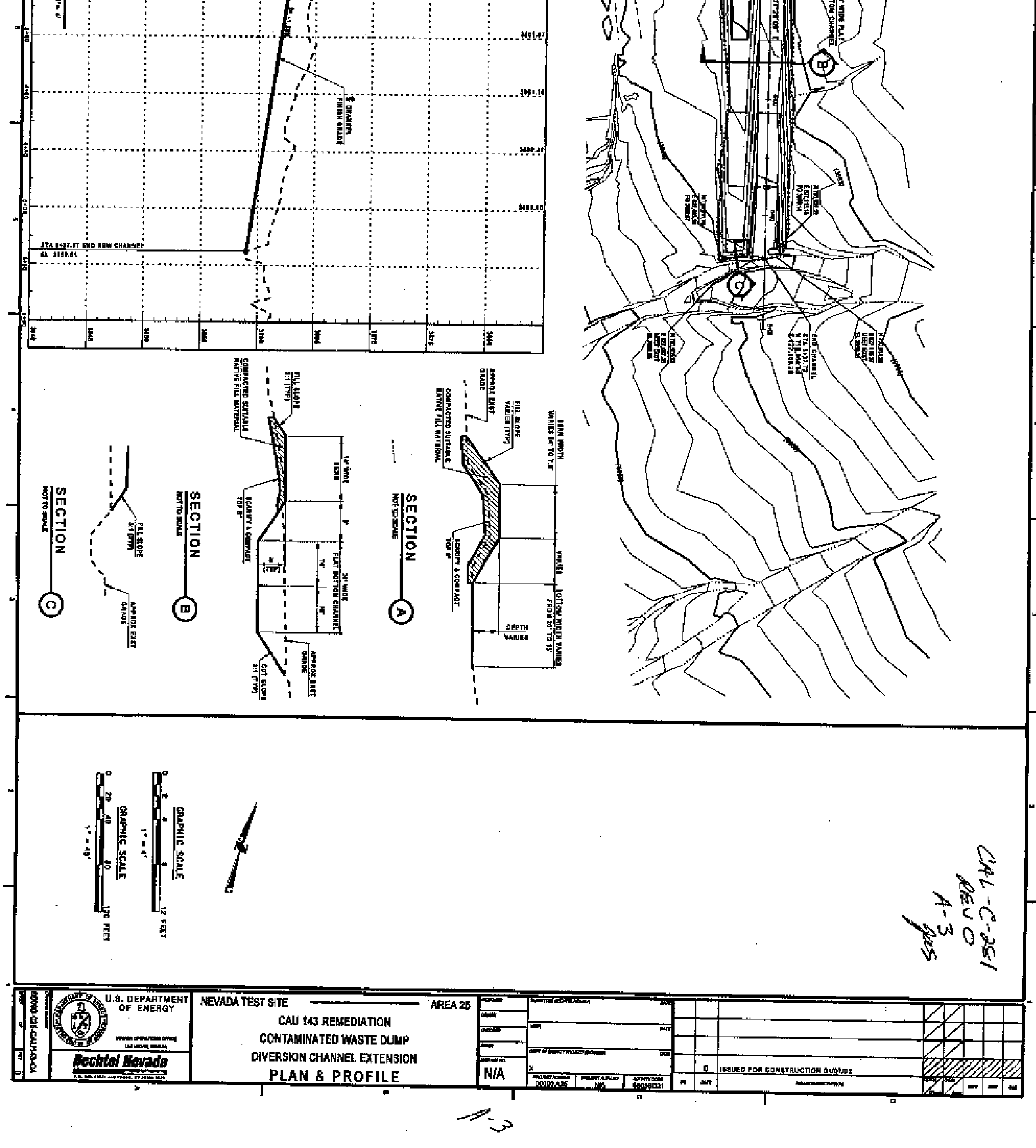


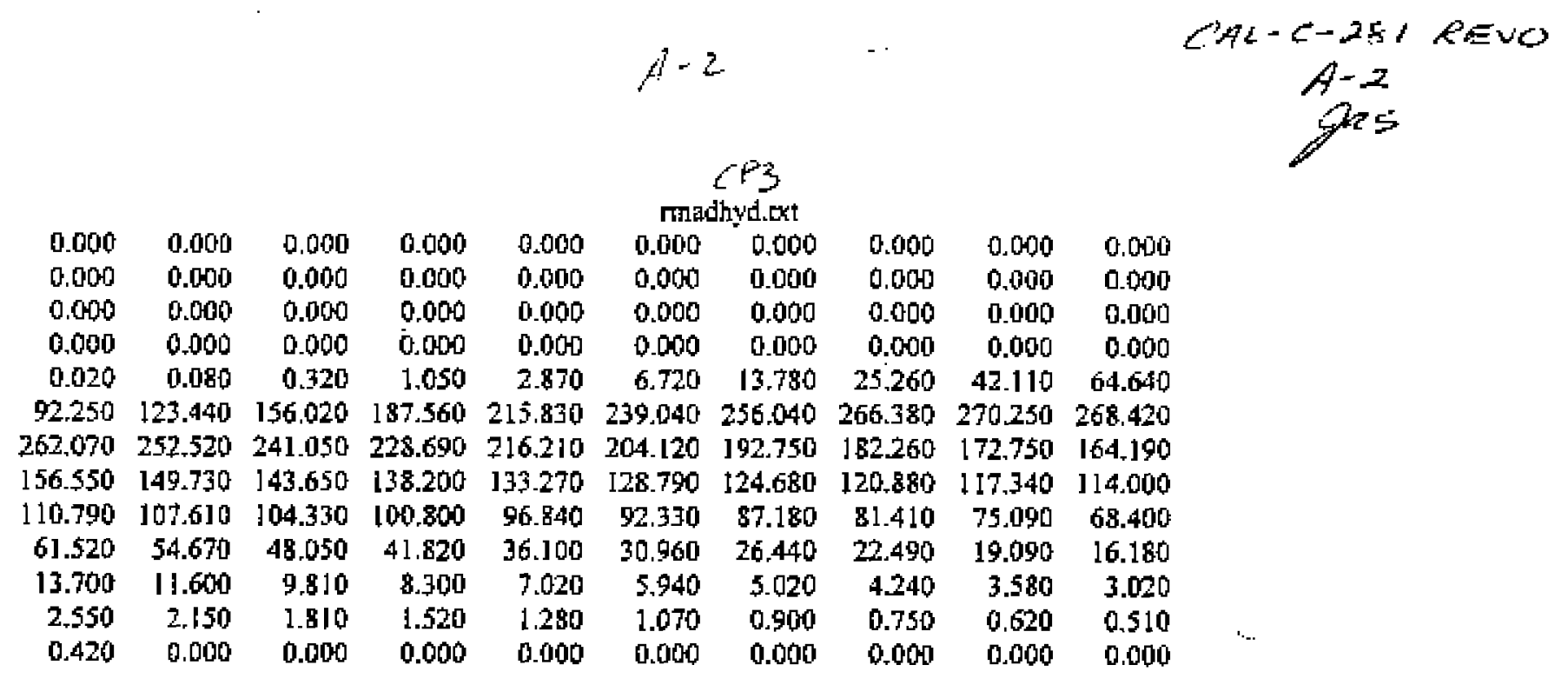




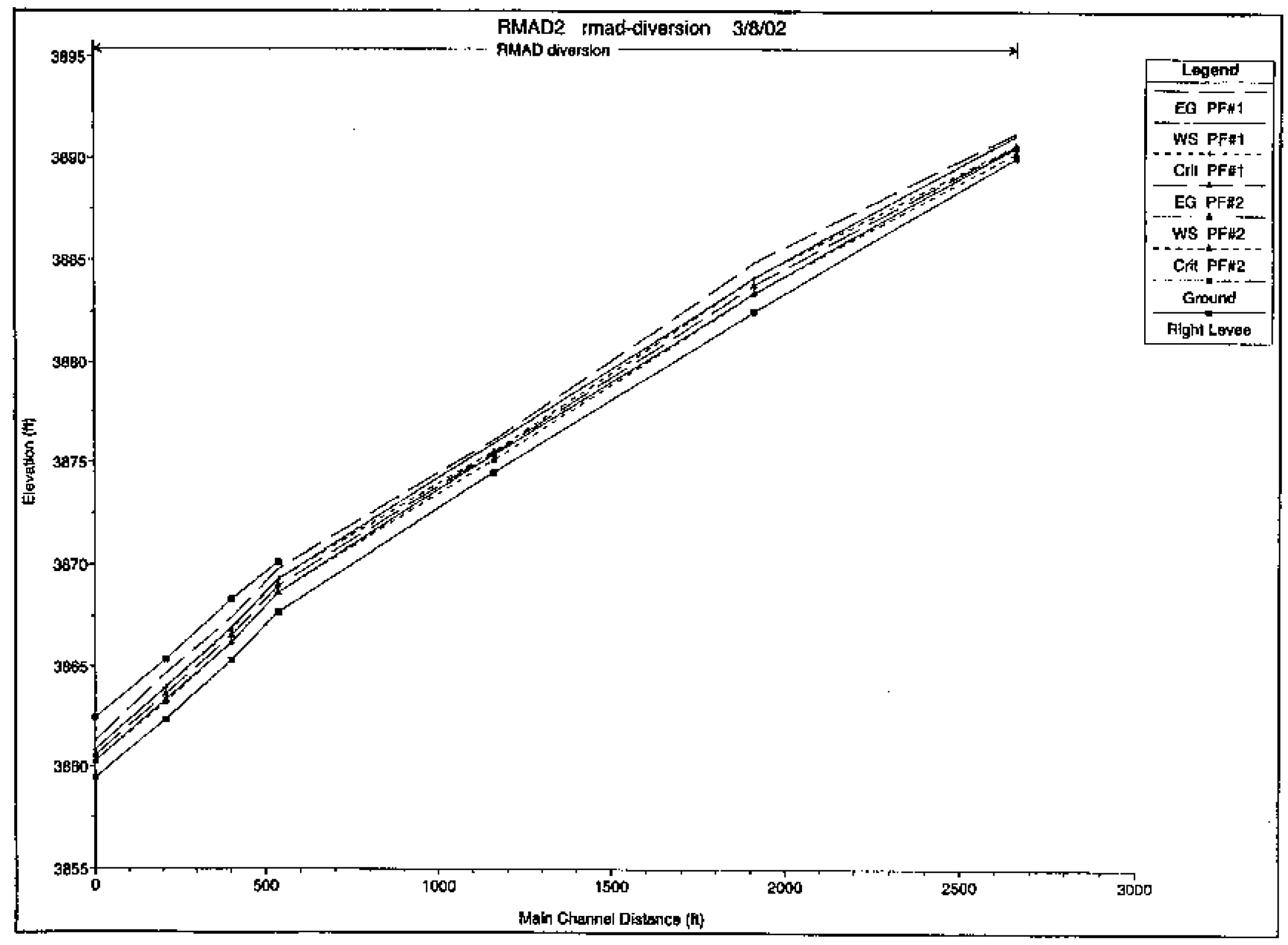




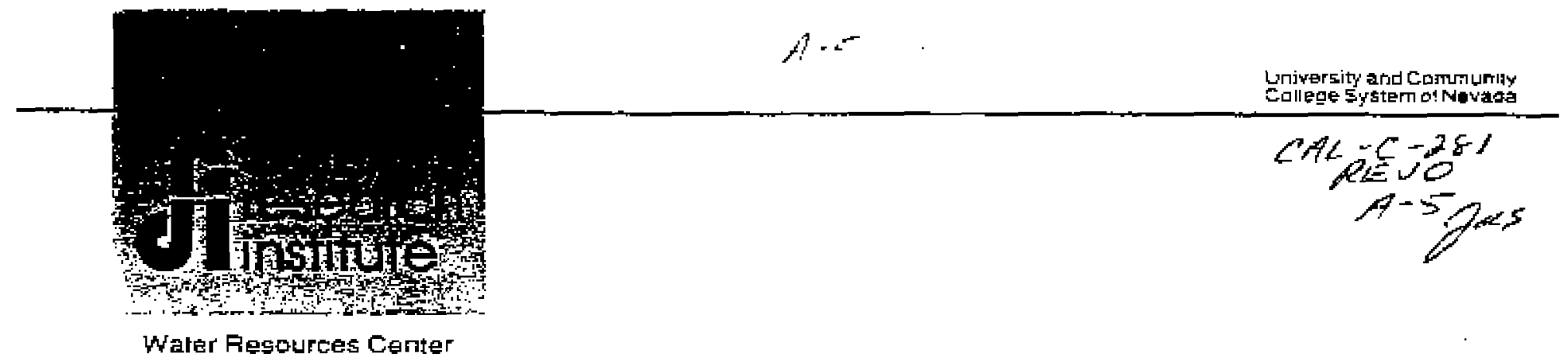

November 5, 1999

Mr. Jhon Carilli, RCRA Program Manager

Waste Management Division

DOE Nevade Operations Office

P.O. Box 98518

Las Vegas, NV 89193-8518

SUBJECT: Certification of Flood Mitigation Structures at the Area 5 RWMS

Dear Mr. Carillt:

I have been involved with flood hazard identification and mitigation at the Department of Energy, Nevada Test Site, Area 5 Radioactive Waste Management Site (RWMS) since flood bazard was identified as a concern during the site characterization process. As an independent reviewer, I examined the documents and maps identifxing flood hazard zones at the RWMS (Sehmeltzer et al., 1993), and the overall design process that led to construction of the flood mitigation structures (dike-channel system) in $1995-1996$. Further, faculty at Desert Research Enstitute, Division of Hydrologic Sciences, closely examined the precipitation event of February 23-24, 1998, which approximated the 25-year, 24-hour precipitation evert for which the dikechannel system at the Area 5 RWMS was designed (French and Curtis, 1999a,b; Francit et at., 1999).

My review of Bechtel Nevade (1999) and the supporting documentation leads me to conclude that the dike-channel system around the RWMS is Area 5 provides adequate rin-on protection from the 25-year, 24-hour precipitation event. Further, based on my inquiry of the persons who prepared Bechtel Nevada (1999), the data and information provided in this cocument are to the best of my knowledge and belief, trite, accurate and complete.

If you have questions, please do not hesitate to contact me. Thank you.

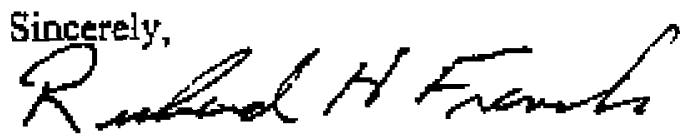

Richard H. French, Ph.D., P.E. Research Professor

ce: E Frant Di Samen DOENV

Wenty Clayton. DOENY

Gary Byter, DOENY

Gent-o' Files, DOENY

Herb Bestinger. BN

Ken Seheekter. BN

2215 Raggio Parkway

Parrict Morthews. BN

Fano. HW $19512 \cdot 1095$

(775) Bra-rist

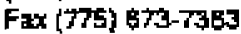


Mr. Thon Carili
November 5,1990

$\gamma-6$

Page $2 / 2$

\section{REFERENCED DOCUMENTS}

Bechtel Nevada, 1999. As-built design analysis for the 25-year, flood protection 5ystem, Area 5 , Radioactive Waste Management Site, Nevada Test Site.

French, RH. and S. Curtis, 1999a. The precipitation event of 23-24 February 1998. Publication No. 45170 , Desert Research Institute, Division of Hydrologic Sciences, Reno, NV.

French, R.H. and S. Curtis, 1999b. Serendipity; capturing a design level precipitation event. Proceedings of the ASCE Water Resources Engineering Division Conference, American Society of Civil Engineers, Seattle, Washington (in press).

French, R.H., T.L. Buchanan, S. Hokett, and S. Curtis, 1999. Calibration of a hybrid rainfallrunoff model in an arid environment. Proceedings of the XXTTH LAHR Congress, International Association for Hydraulic Research, Graz, Austria (on CD Rom).

Schmeltzer J.S., J.J. Miller, D.L, Gustafson, 1993. Flood assessment at the Area 5 Radioactive Waste Management Site and the proposed hazardous waste storage unit, DOENevada Test Site, Nye County, Nevada, U.S. Depariment of Energy, Las Vegas, Nevada. . 


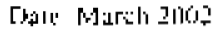

\section{APPENDIX B}

\section{CONFIRMATION SAMPLING TEST RESULTS}


C:sure Reporl - Cal : 1:1

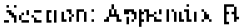

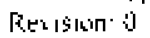

[Dolu: Anarch $30 \%$

THIS PAGE INTENTIONALLY LEFT BLANK 
COVER PAGE

Sanford Cohen \& Asspociates

Southeastem Envirommental Laboratory

1000 Monticello Court

Montgomery, Alabama 36117

Laboratory Code: SCA Contract Number: 30025

Laboratory Report Identification Code: 2694, 2695 SDG: V1 349

Sample Matrix: Soil

\begin{tabular}{|c|c|}
\hline \multirow[t]{2}{*}{ Site Sanple Numbers } & Laboratory Sample Number \\
\hline & Tritium \\
\hline CWD-5-1 & NTS01-2694-01 \\
\hline CWD-S-2 & NTS01-2694-02 \\
\hline CWD-S-3 & VTS01-2694-013 \\
\hline$C T^{2}-5-4$ & NTS01-2694-04 \\
\hline CWD-S-5 & NTSOl-2694-05 \\
\hline CWD-S-6 & NTSQ]-2694-06 \\
\hline Laboratory Control Sample (LC) & \$CACC-2694-LCE \\
\hline Duplicate $\{\mathrm{LD}\}$ & SCAOC-2694-LDI \\
\hline Preparation Blank (PB) & SCAQC-2694+PB \\
\hline
\end{tabular}

Sample Matrix: Water

\begin{tabular}{|l|l|}
\hline \multicolumn{1}{|c|}{ Site Sarple Numbers } & Laboratory Sample Number \\
\cline { 2 - 2 } & Tritiul \\
\hline CWD-EB-1 & NTSOI-2695-01 \\
\hline Laboratory Cantol Sample (LC) & SCAQC-2695-LC \\
\hline Duplicate (LD) & SCAQC-2695-LD1 \\
\hline Freparation Elank (PB) & SCAQC-2695-PE \\
\hline
\end{tabular}

Comments: There were no problems encountered during sample receiving.

"I certify that this sample data package is in compliance with SOW requirements, both technically and for completencss, other than the cooditions detailed above. Release of the daca contained in this hard-copy sanple data package and the computes-readable EDD, as appliegble, subnaitted on diskerte or by moden, has been authorized by the laboratory Manager or the Marager"s designee, as verified by the following siganure."

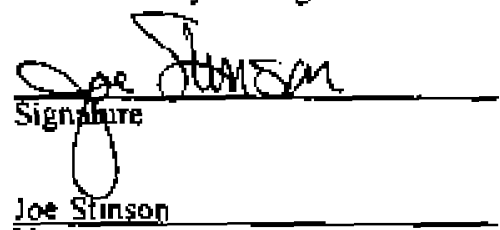

Nat
L.aboretory Mattager

Tithe
$12-19-01$

Dete 


\section{Bechtel Levada}

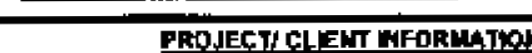

\begin{tabular}{|c|c|}
\hline \multicolumn{2}{|c|}{ 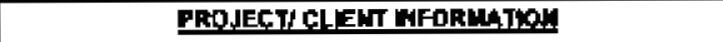 } \\
\hline Proped: $\mathrm{C} / 4,43$ & Bat orp: 2,54 \\
\hline 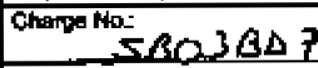 & ASL Prod: \\
\hline Prupar Wanager $\omega_{\alpha}, A$ & $50 \mathrm{~N}$ \\
\hline $5=0573$ & $A \angle T^{+}+30$ \\
\hline
\end{tabular}

SERVICES REQUEST \& CHAIN OF CUSTODY RECORD

EEPORT MFORWATHOH

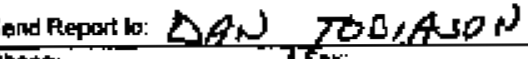

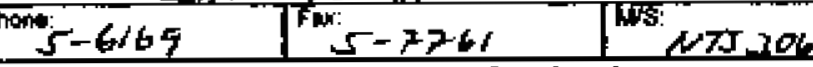

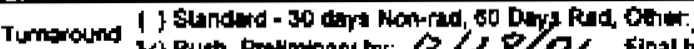
X kuth Preinnary by: $R / 2 P / C L$ final by:

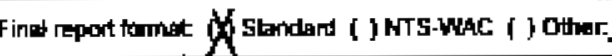

:

\begin{tabular}{|c|c|}
\hline R-d SGO; & Har-Fad bog: \\
\hline Fad Pather: & NonkRed Fratat \\
\hline
\end{tabular}

Ciant Gowos Represemathe:

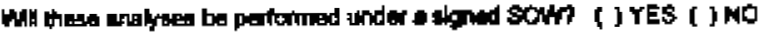

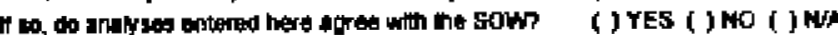

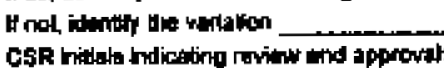

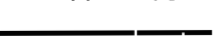

\begin{tabular}{|l|l|l|l}
\hline$i$ & ID IOEgCRIPTON & BMPLEN & \\
\hline
\end{tabular}

$c \omega t-5=1$

1. $\cos B-s-2$

$2 C \omega D=5-3$

$3 \quad C O A=P-4$

$4 \operatorname{Cln} \mathrm{A}-\mathrm{S}=5$

$5 C \omega h-S-6$

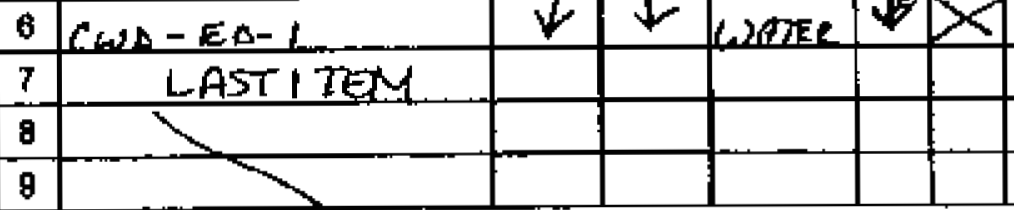

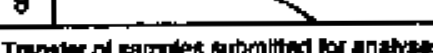

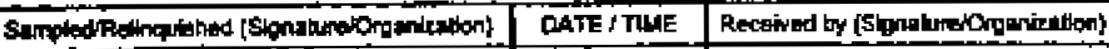

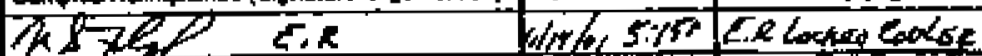

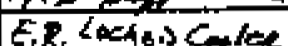
$\operatorname{lin}_{42} 20$

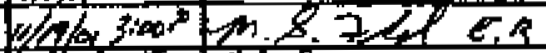

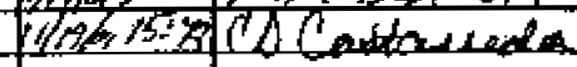

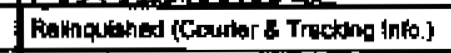

\section{ANALYSES \& METHOD}

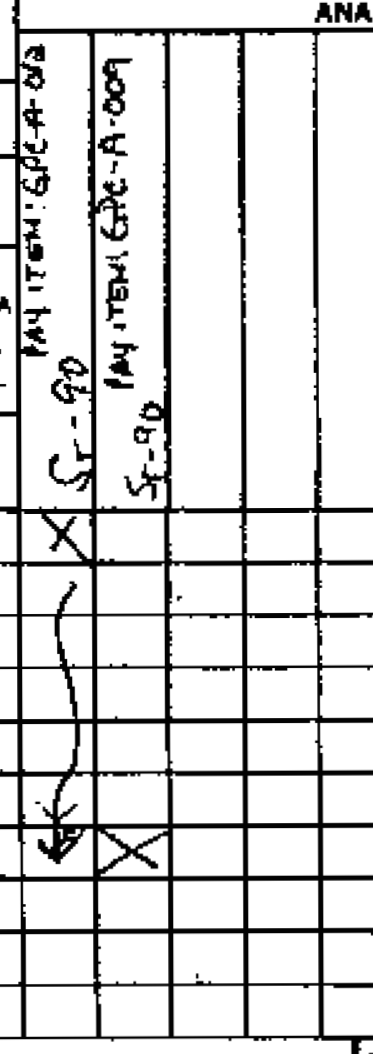

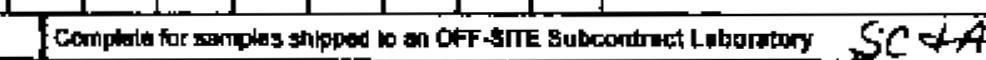

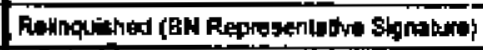
WOAmbwa fed Ex mal wos laogy

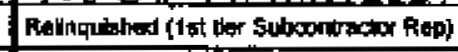

N150 $-2695-01$

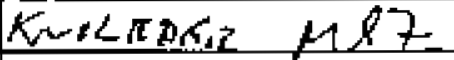

Page 1 of 1

Sotpling stto: $(P L A L 2$.

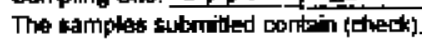

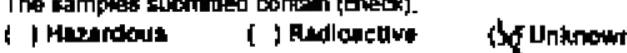

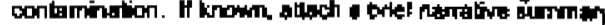

identiffing carilaminants. This informetion will ansure

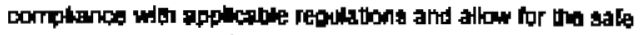

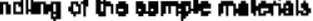

\begin{tabular}{|c|}
\hline 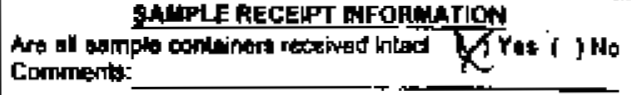 \\
\hline $\begin{array}{l}\text { Cow the labats ogree with thit form? } \\
\text { Comments. }\end{array}$ \\
\hline 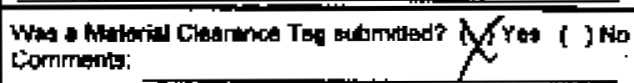 \\
\hline
\end{tabular}

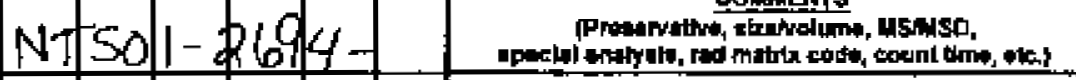

500 bo L Nalsent $40^{\circ} \mathrm{C}$

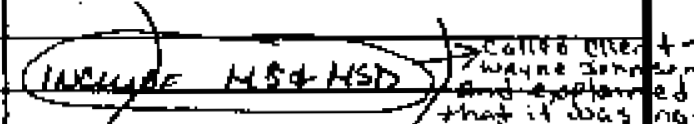
moms? kadielogickl tisting

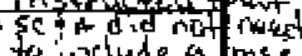

Wo pas 7 th Paters

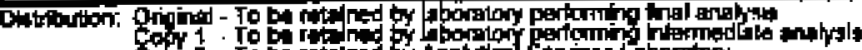

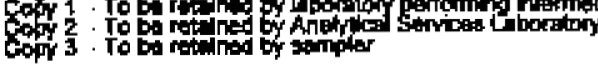




\section{Introduction}

December 19, 2001

On November 21, 2001, one water sample and six soil samples were received for analysis at the Sanford Cohen and Associates (SC\&A) Southeastern Environmental Laboratory, located it Montgomery, Alabama. The samples were requested to be analyzed withit 28 days of receipt at the Jabotatory. The samples were analyzed in accordance with the Becbte! Nevada Services Subcontract Task Order Agreement Form, Exhibit B, Statement of work and Specirications, Rev 1, 1/23/01.

\section{Analytical Methodology}

The radioanalytical results reported for these samples include the site and laboratory sample identification numbers, collection date, method of analysis, and the quality control samples that were analyzed concurently. The Samples were analyzed in accordance with the following method.

\begin{tabular}{|c|c|c|c|}
\hline Radionuclide & $\begin{array}{c}\text { Method } \\
\text { Number }\end{array}$ & Method & Counting \\
\hline Sr-90 & SRwol & Eichrom Industries & Gas Proportional \\
\hline
\end{tabular}

\section{Anglytical Results}

\section{Deficiencies}

None.

\section{Matrix Interferences}

There were no indications of matrix interference.

\section{Dilutions}

No dilutions were required.

\section{Detection Iimits}

The required detection limit (RDL) was not met for the water sample (NT\$01-269501) because of the linited wolume of sample available and the necessity to run the sample in duplicate. All other RDLs were met for the renaining analyses.

\section{Reanalysis}

There were no reanalyses. 


\section{Deviations from Protocols}

There were no deviations from the written protocols and analytical methods.

Contacts with the CTR

MS and MSD were indicated on the COC. A call was made to Mr. Wayne Johnson to confirm that these were not required. Accordingly they were not performed.

\section{F. Quality Control}

Sitc Samples Used for Quality Control Samples: Soils

\begin{tabular}{|c|c|c|}
\hline Site Sample Number & Laboratory Sample Number & $\begin{array}{c}\text { Type of Quality Control Analysis } \\
\text { Sample }\end{array}$ \\
\hline Laboratory Type II Water & SCAQC-2694-LCl & Laboratory Control Sample \\
\hline Preparation Blank & SCAQC-2694-PB & FTeparation Blank \\
\hline CWD-s-1 & SCAQC-2694-LDl & Laboratory Duplicate Sample \\
\hline
\end{tabular}

Site Samples Used for Quality Control Samples: Waters

\begin{tabular}{|c|c|c|}
\hline Site Saruple Number & Laboratory Sample Number & $\begin{array}{c}\text { Type of Quality Control Analysis } \\
\text { Sample }\end{array}$ \\
\hline Laboratory Type II Water & SCAQC-2695-LCI & Laboratory Control Sample \\
\hline FTeparation Blank & SCAQC-2695-PB & FTeparation Blank \\
\hline CWD-EB-1 & SCAQC-2695-LDl & Laboratory Duplicate Sample \\
\hline
\end{tabular}

The analytical results of all quality control samples met the acceptance criteria specified in the SOW.
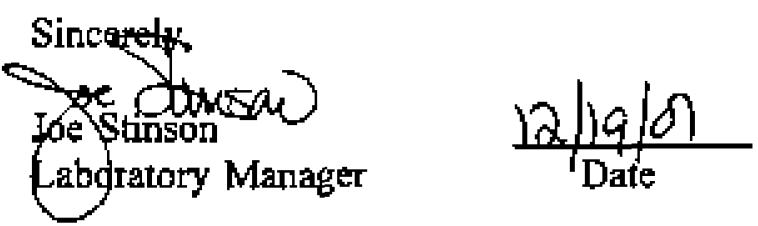
Sample and QC Sample Results Summary 


\section{Sanford Cohen \& Associates \\ Southeastern Environmental Laboratory \\ Radioanalytical Results}

Repert Identifieatlon Number: V1349

Froped Nana. Eechlolel Newada

Site sample ID: chprs-1

Other Sample ID:

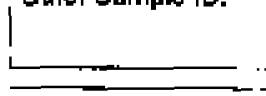

Method turnter SRW01

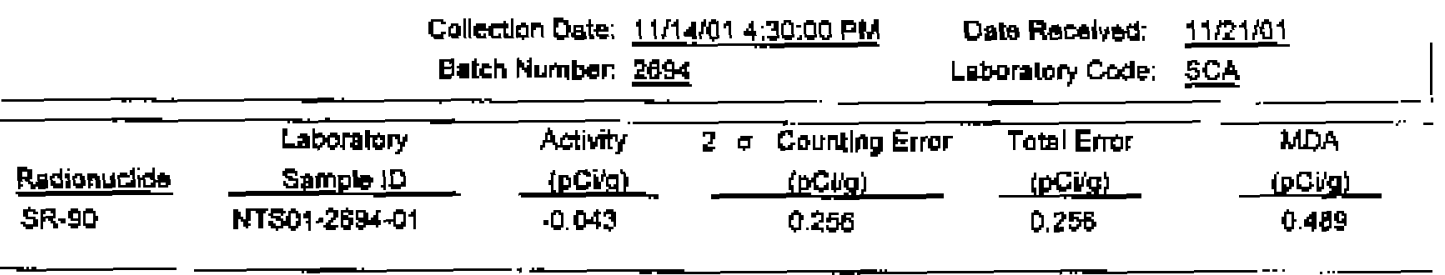

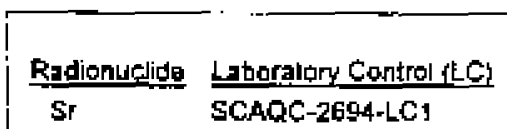

$5 r$ SCAQC-2694-LCI

$$
\text { Enain-of-Custody Number: NOWE }
$$

Matrix: Soil

Laboniplory Dyplicsto (LD) Matrix Spike (MS)

SCAOC-2694-D1
PrEparation Blank (FB) SCAOC-26日4-PB 
Santord Cohen \& Associates

Southeastern Environmental Laboratory

Radloanalytical Results

Report ldemilifenlion Mumber. W1349

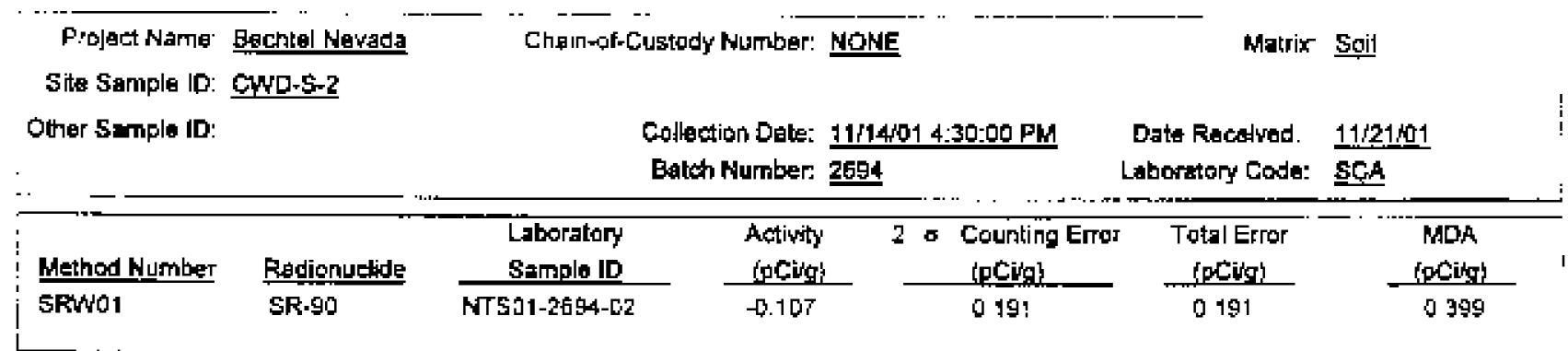

Quzlity Contres Samplas

\begin{tabular}{|c|c|c|c|c|}
\hline Roduonuclistel & Lequoritory Confol i LC) & 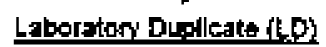 & Metrax spife & Preperatron Blank (PB) \\
\hline 5. & SCAOC-2694-LC1 & SCAOC-2594-LOH & & SCAOC-2694-F日 \\
\hline
\end{tabular}




\section{Sanford Cohen \& Associates \\ Southeastern Environmental Laboratory}

Radioanalytical Residts

Report Ifentificalian Number: V1349

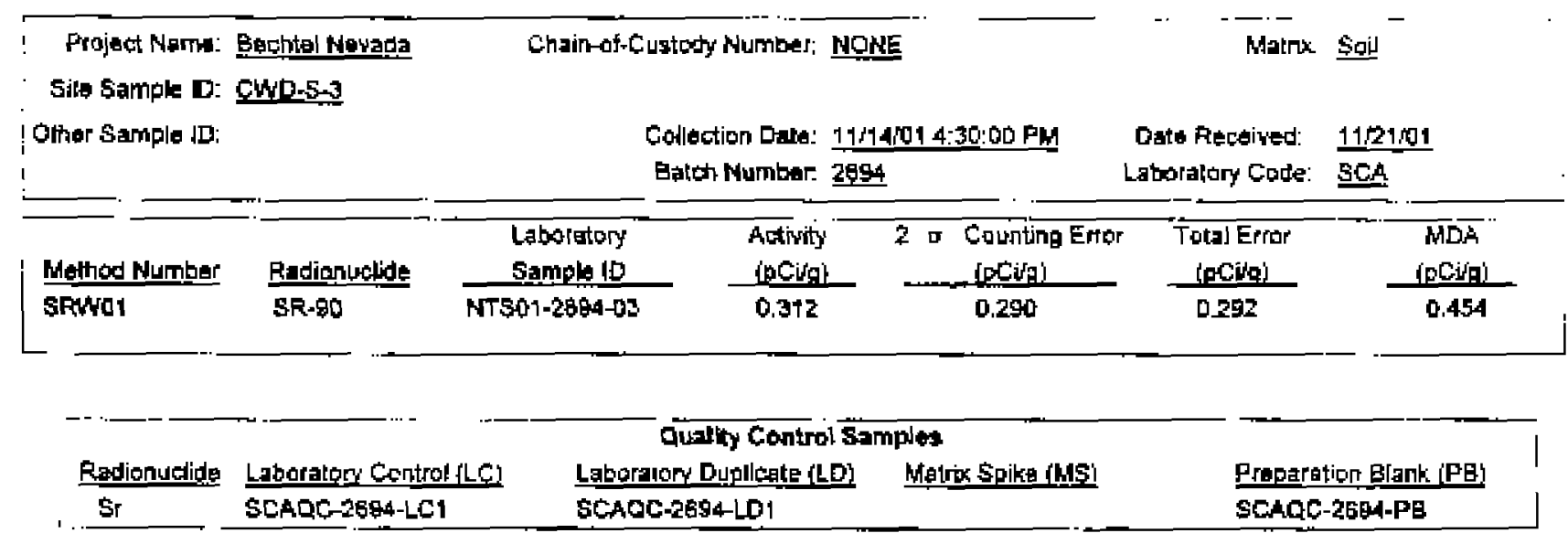


Sanford Cohen \& Associates

Southeastern Environmental Laboratory

Radioanalytical Rosults

Raport temtifiction Numbor: W1349

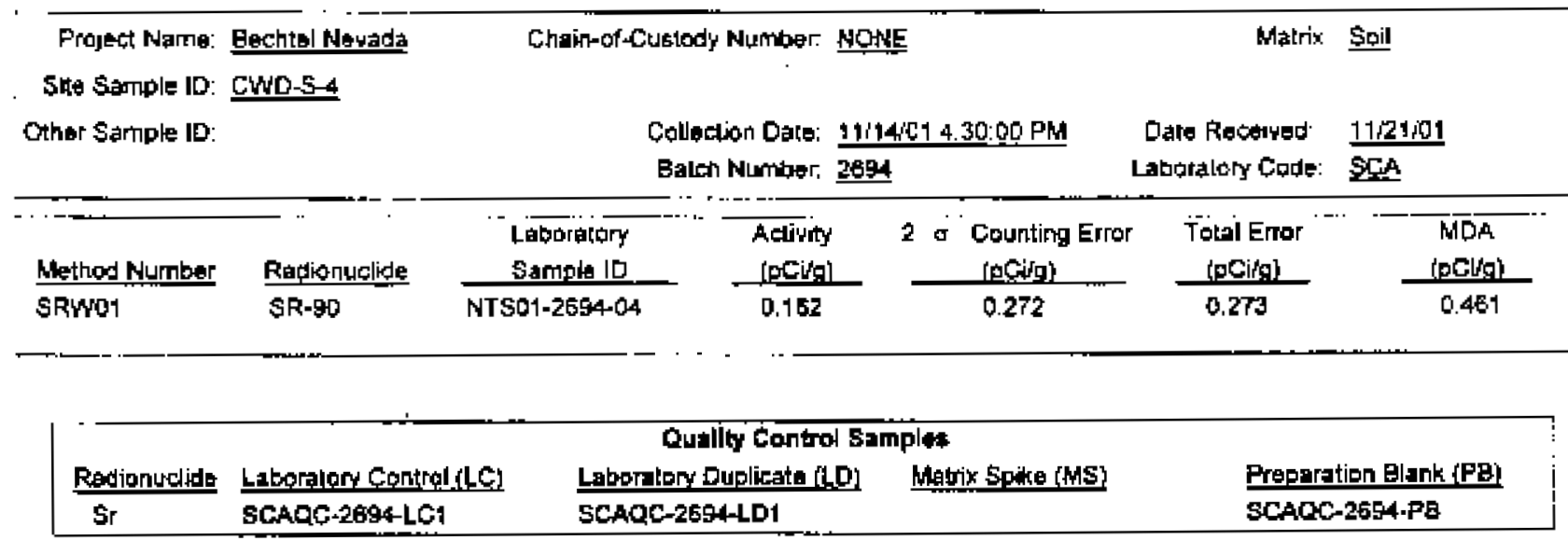




\section{Sanford Cohen \& Associates \\ Southeastern Environmental Laboratory \\ Radioanalytical Results}

Fieport Idẹntifieation Number: W1349

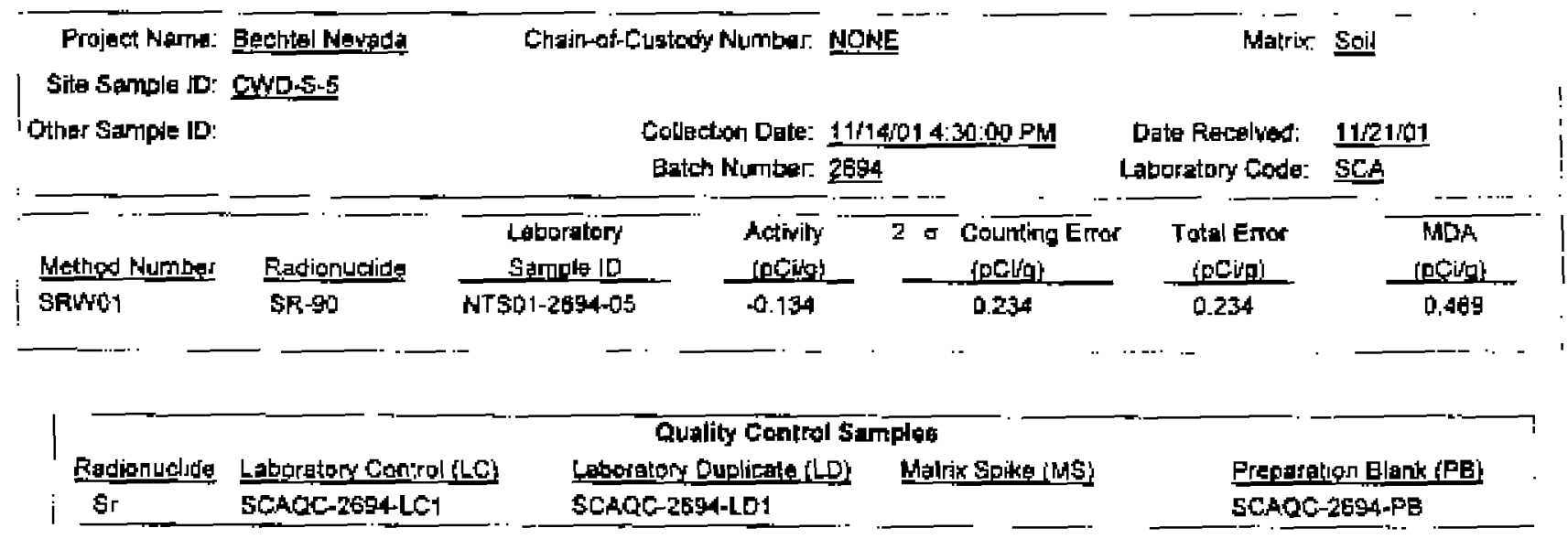


Sanford Cohen \& Associates

Southeastern Environmental Laboratory

Radioanalytical Results

Fiapor Ifentification Number: W1349

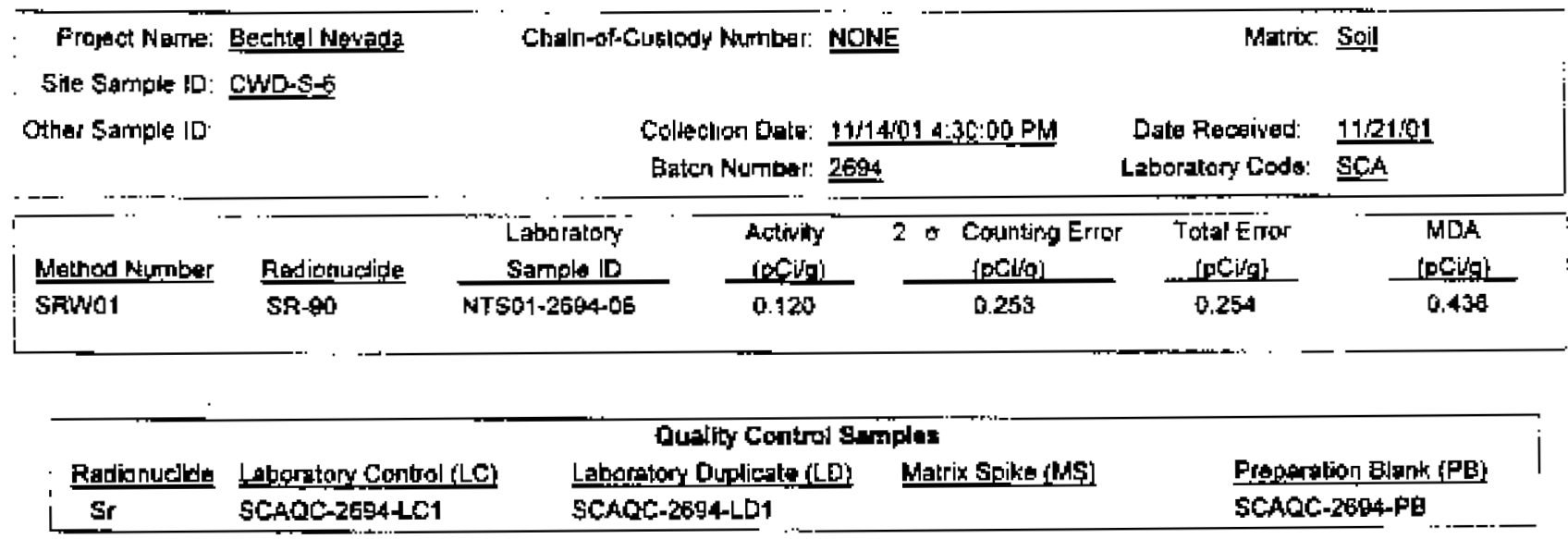




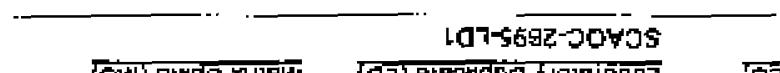

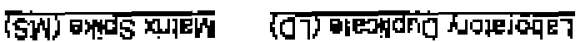
tejdures lonuog hllemo

\begin{tabular}{|c|c|c|c|c|c|c|c|}
\hline$\Phi \Phi^{-1}$ & 0,00 & \multicolumn{2}{|l|}{0900} & $690 \%$ & $10-5692-105 \perp N$ & \multicolumn{2}{|r|}{ loMts } \\
\hline 77,400 & Tाभव & ‘रकd] & & (पाकब & वा बादWES & Epifnuoipey & 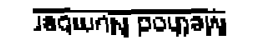 \\
\hline WOH & ل & Jau & $\bullet E$ & SHP & Hopejoqu & & \\
\hline$\overline{W s}$ & 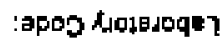 & & & E = & & & . \\
\hline$\overline{\text { मMLI }}$ & 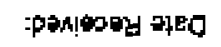 & Nid Daide & 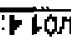 & T ipleg th & & & 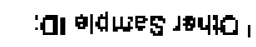 \\
\hline & & & & & & l- & 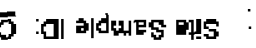 \\
\hline$\overline{\sqrt{\sigma} \bar{E}_{h}}$ & :xylepr & & & N :小 & $n-10-4 \mid$ & 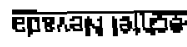 & 百 ZRUEN WE[OJd \\
\hline
\end{tabular}

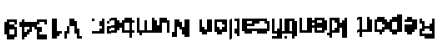

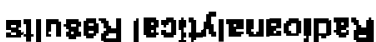

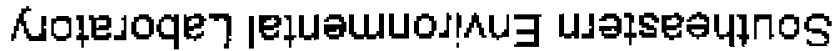

selelooss $\forall 8$ vayoo pjojues 
Sanford Cohen \& Associates

Southeastern Environmental Laboratory

Radtioanalytical Resiults

Quality Control 8amplo

Laboratory Control \{LC1\}

Report Identification Number ' 1344

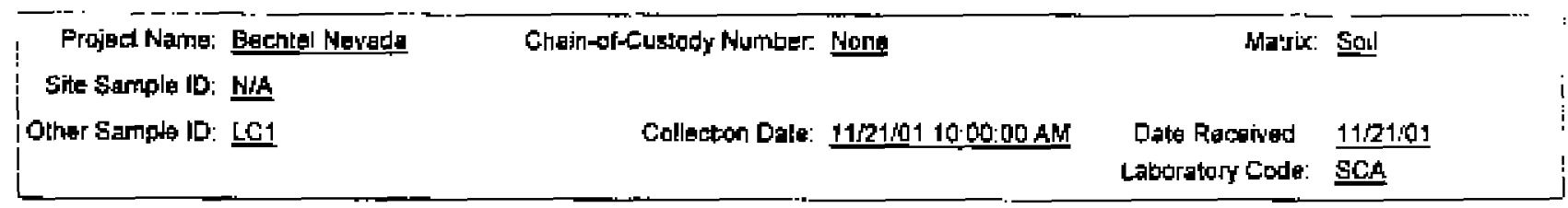

\begin{tabular}{|c|c|c|c|c|c|c|}
\hline Melhod Number & Radjorduclide & $\begin{array}{l}\text { Laborrtay } \\
\text { Sample lo }\end{array}$ & $\begin{array}{l}\text { Activily } \\
\text { cocidg }\end{array}$ & $\begin{array}{ll}2 \text { agunting Emor } \\
\end{array}$ & $\begin{array}{l}\text { Total Error } \\
\text { toGung }\end{array}$ & MDA \\
\hline SAWN1 & 5R.50 & SCAOE-2694-LC1 & 833 & 16.7 & 84.9 & 0.822 \\
\hline
\end{tabular}

\begin{tabular}{|c|c|c|c|c|}
\hline \multirow[b]{2}{*}{ Fatdionuclidg: } & \multicolumn{4}{|c|}{ Guality Gontrol Semplas: } \\
\hline & Laboretory Conuol (LC) & Leborntar Duplkale (LD) & Walrix Spike (NS) & Prepseralian Blank (PE) \\
\hline SI & SOROC-2694-LC1 & SCAOC-2694-LD1 & . & SCAQC-2694-PB \\
\hline
\end{tabular}




\section{Sanford Cohen \& Associates \\ Southeastern Environmental Laboratory}

Radioanalytical Results

Quality Control Gample

Laboratory Control (LC1)

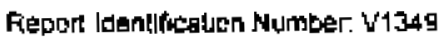

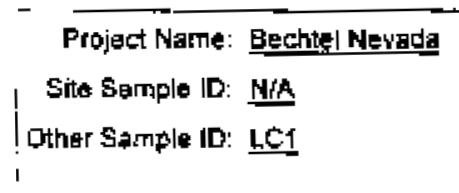

\begin{tabular}{|c|c|c|c|}
\hline Mathod Number & Radinfudide & $\begin{array}{l}\text { Laboralory } \\
\text { 5nmple } 10\end{array}$ & $\begin{array}{l}\text { Activily } \\
\text { ipCít' }\end{array}$ \\
\hline SRMPOI & SR-gh & 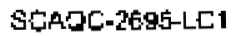 & 1ETD \\
\hline
\end{tabular}

\begin{tabular}{|c|c|}
\hline $\begin{array}{l}\text { Eptunting Eirar } \\
\text { [pCinl }\end{array}$ & $\begin{array}{c}\text { Total Error } \\
\text { GPCLE) }\end{array}$ \\
\hline 33.3 & 170 \\
\hline
\end{tabular}

\begin{tabular}{|c|c|c|c|}
\hline \multirow[b]{2}{*}{ Radionupida } & \multirow[b]{2}{*}{ Laboratory Control (LG) } & \multicolumn{2}{|c|}{ Quatiy Control Sempien } \\
\hline & & Laboralory Dupheato (LD) & Metrux solke (MS) \\
\hline $5 r$ & 5CALC-2695-LC1 & SCAQC-2595-L1 & \\
\hline
\end{tabular}




\section{Sanford Cohen \& Associates}

\section{Southeastern Enviromental Laboratory}

Radioznalytical Resu|ts

\section{Quality Control Sample}

Duplicate \{LD1\}

Report ldontifiçation Number. W1345

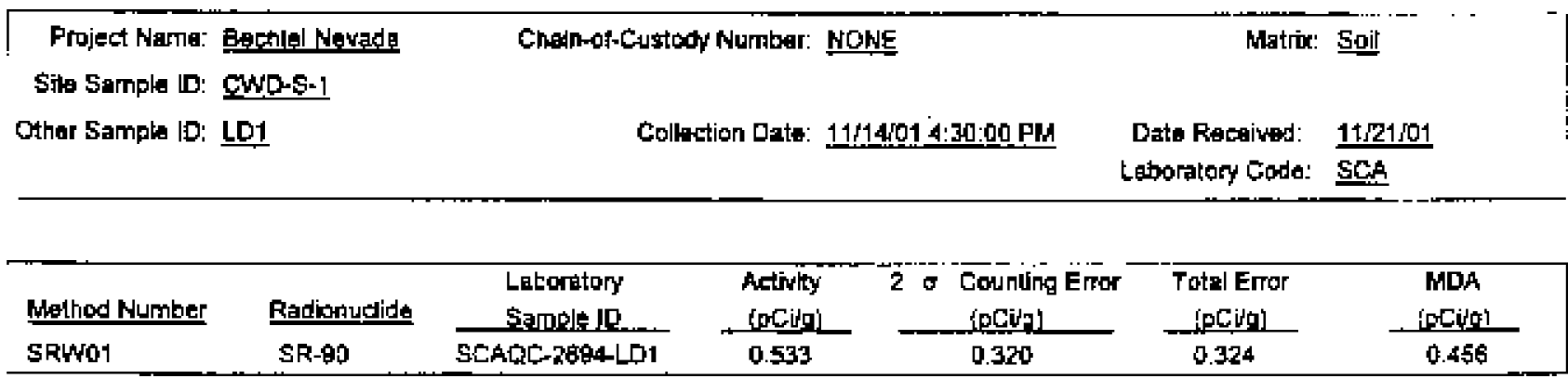

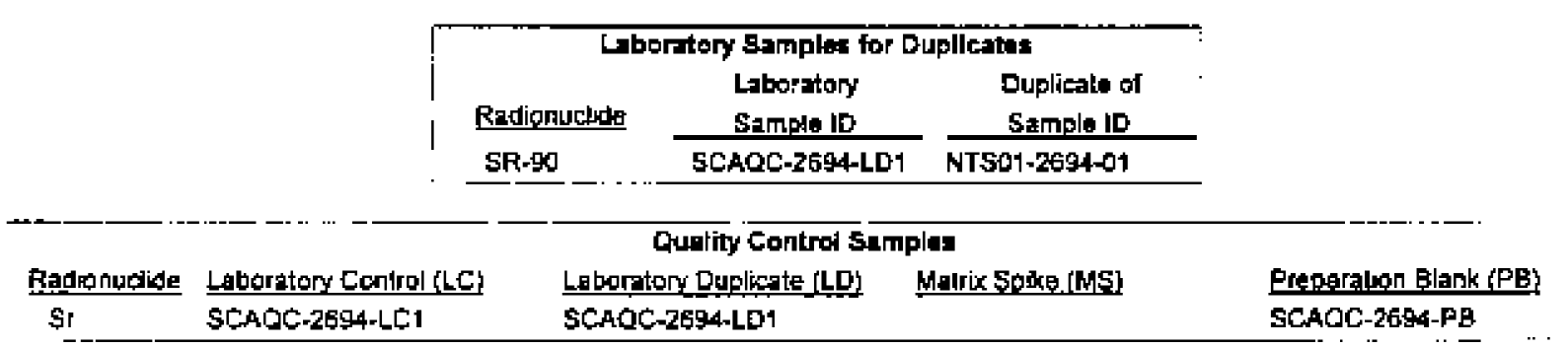




\section{Sanford Cohen \& Associates \\ Southeastern Environmental Laboratory \\ Radioanalytical Rasults}

\section{Qually Contral Sample \\ Dupltcate (LDT)}

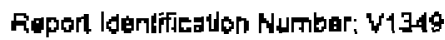

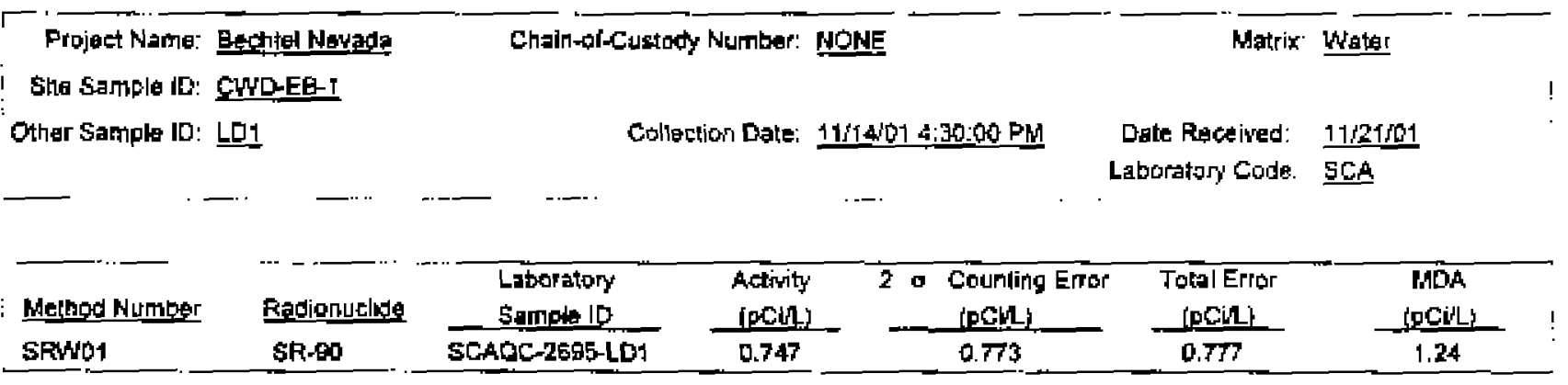

|


Sanford Cohen \& Associates

Southeastern Environmental Laboratory

Radioanalytical Results

Quality Control \$ampla

Proparation Elank (PB)

Repport Identficat|on Number. V1349

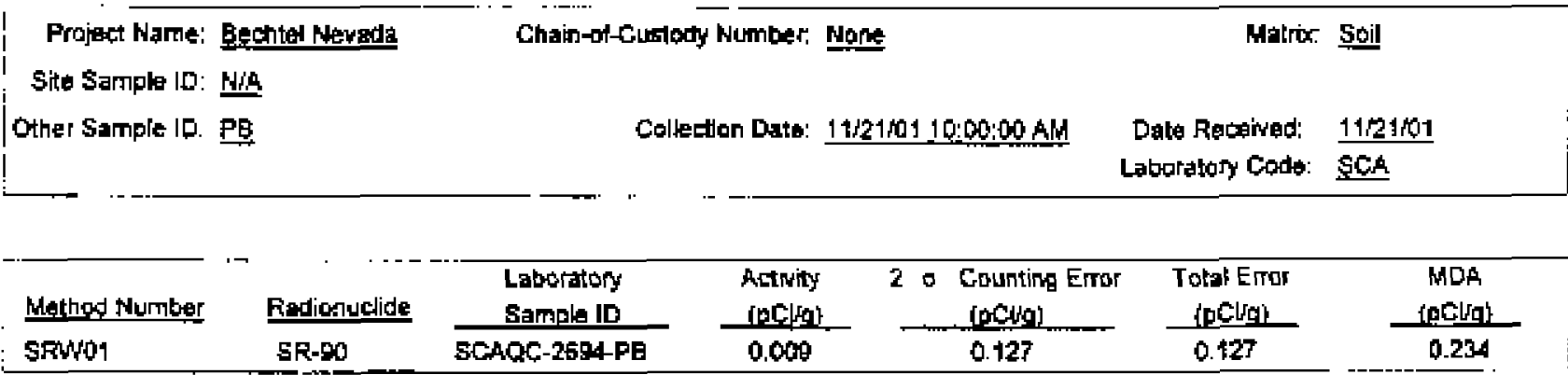

\begin{tabular}{|c|c|c|c|c|}
\hline & & Qually Controils & Fines & \\
\hline Radjonuclida & Laborakory Control (LC) & Laboratory Dypliate cLin & Matrix soike (MSS) & Preparation Blank [PB] \\
\hline $5 r$ & SCAOC-2694-LC1 & SCAOC-2694-LD1 & & SCAQC-2B94-PB \\
\hline
\end{tabular}




\section{Sanford Cohen \& Associates}

\section{Southeastern Environmental Laboratory}

\section{Radioanalytical Results}

Qually Control Sample

Preparation Blank (PB)

Report loentification Number: W 1349

\section{Froject Name Eechiel Neriada \\ Sire Sampla JE: NHA}

Other Sarmple ID: $\underline{P B}$
$-$

Chain-ol-Cugrody Number None

Colbetion Date: $11 / 2+101$ 10000:00 AM
(1)

Małrix: Walter

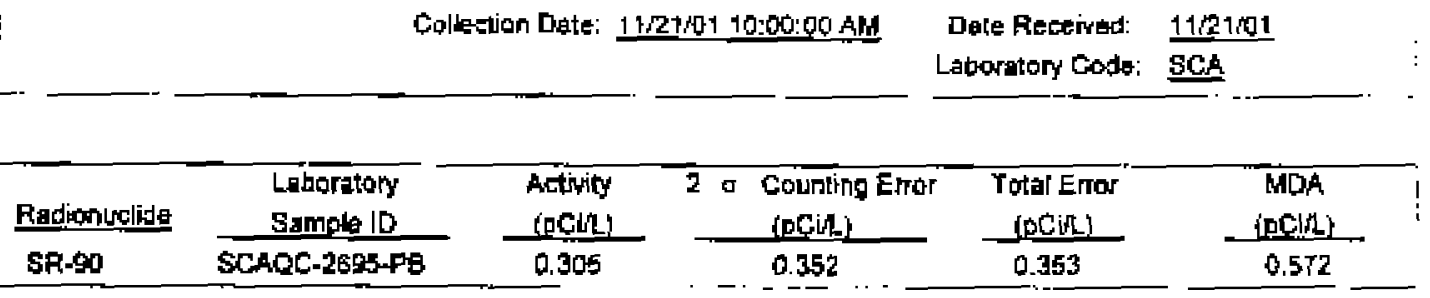

Oual ty Controf Sarmpias

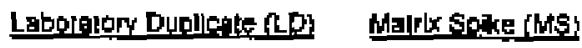
SCAOC-2695404
Erapomilion Elank (PB) SCAQC-2695-PE 


\section{Sanford Cohen \& Associates \\ Southeastern Environmental Laboratory \\ Radioanalytical Results}

Quality Control Sample Evaluation

Repor tedentificalian Number: W1349

Prcject Name: Eechtel Menada

Matrix. Sol

Laboratory Code: SCA

\section{Laboratory Contol Sample (LC1) Evaluatlon}

(C))

Decay Cortected

Acdivity of

Radianurelide $\frac{\text { Labofalory }}{\text { SEmpote ID }}$

Method Number

SRWt01 SF-96
Spike Added

[PCidg)

$465 \pm 43.3$
(OW)

Laboratory Control

Sample Activity

(pCing)

833 \pm 49
Laboratory Control

sample

$\%$ Recovery

(Aoctrach)

96.2
Mumper of $x$

Bebmegr CW and QV

\section{Laboratory Dupleate Sampla (1.D1] Evaluatlon}

Whanged Number SFrwo1
Laboralory

Radionuctide

SR-go 5ample I0 SCAOC-2的ALD1
Original Sample

Antivity

(acitgl)

$0.043 \pm 0.256$
Diftertence Betrean

Original Afrisity and

Duplieale Sample Activity

Aclivity

[pCUg]

$0.533 \pm 0.324$

[F] 0.577
Ratip of tho Differenco Between the Sample Acruitirs ath the

Propagated

Meqguriomeant Driginal Aderily and

Uncertaitly of the

Difference at 2 o
— $\mathrm{F} F$

1.39

Laboratory Contol Sample (PB) Evaluation

\begin{tabular}{|c|c|c|c|c|c|c|c|c|c|}
\hline od 1 & Badionuclide & $\begin{array}{l}\text { Laboratory } \\
\text { Santople ID }\end{array}$ & $\begin{array}{l}\text { Activitb } \\
\text { accild }\}\end{array}$ & $\begin{array}{l}\text { MDA } \\
\text { (pCita) }\end{array}$ & 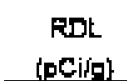 & $\begin{array}{c}\text { All Samples } \\
\text { Detemplot }\end{array}$ & $\begin{array}{c}\text { All Samples } \\
\text { > ROLL }\end{array}$ & $\begin{array}{c}\text { Aal Samples } \\
\text { < RDL }\end{array}$ & $\begin{array}{l}\text { Accept } \\
\text { PB }\end{array}$ \\
\hline SRW01 & SR-90 & SCAOC-25日4PB & 0.009 & 0.234 & 1.00 & No & No & Yen & Yeg \\
\hline
\end{tabular}


Sanford Cohen \& Associates

Southeastern Environmental Laboratory

Rodioanalytical Results

Quality Control Chemical Recovery

Feport Identifieatlen Numbers. W/349

\begin{tabular}{|c|c|}
\hline Laboratory Sample ID & $51-90$ \\
\hline NTS01-2594-01 & 92.01 \\
\hline NTSO1 -2594-01 & 92.04 \\
\hline NTSO1.2694-02 & 100.59 \\
\hline NT多01 -2894-02 & 100.69 \\
\hline NTS01-2694-03 & 92.01 \\
\hline NTSO1-2694-03 & 62.01 \\
\hline NTS01-2594-04 & 95.49 \\
\hline NTS01-2694-04 & 95.49 \\
\hline NTSO1-2644-0S & 98.09 \\
\hline NTS01-2694-05 & 98.09 \\
\hline NTSO1-2094-06 & 102.43 \\
\hline NTSQ1-2594-65. & 102.43 \\
\hline NTSO1-2695-01 & 66.91 \\
\hline NTS01-2595-01 & $86.8 \%$ \\
\hline SCAOC-2694-LC1 & 90.28 \\
\hline SCAOC-2694-LC1 & 90.28 \\
\hline SCAOC-2694-LD1 & 92.88 \\
\hline 5CAOC-2694-L1 & 92.99 \\
\hline \$CAOC-2694-PB & 90.28 \\
\hline SCAOL-2694-PE & 90.28 \\
\hline SCAQC-2095-LC 1 & 85.07 \\
\hline SCAQC-2ES5-LC1 & 85.07 \\
\hline SCAOC-2695-D1 & 90.28 \\
\hline SCAOC-2695-L1 & 90.28 \\
\hline SCAQC-2695-PB & 95.94 \\
\hline SGACG-2695-PE & 85.94 \\
\hline
\end{tabular}




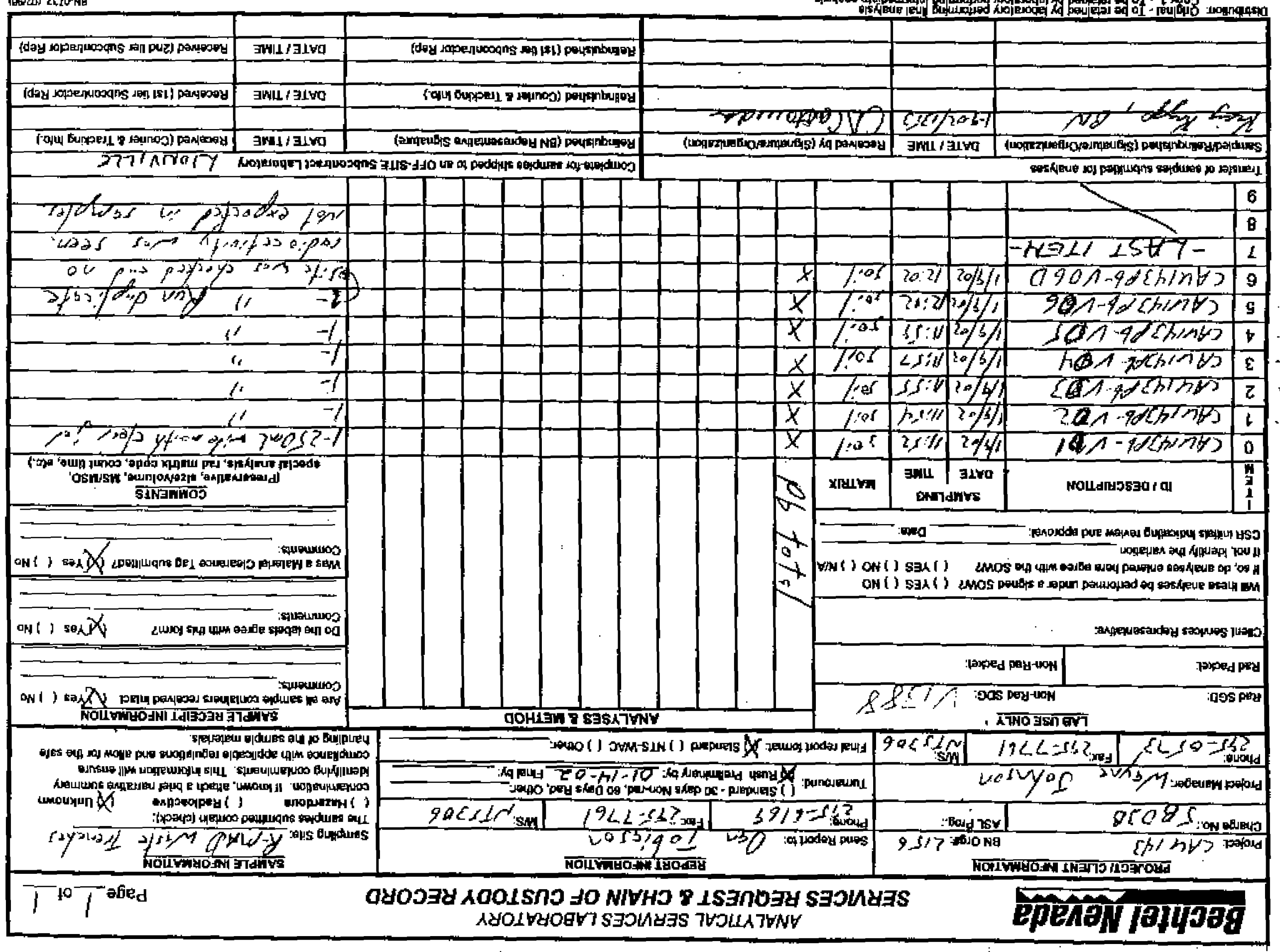


U.S. EPA

COVER PAGE - INORGANTC ANALYSES DATA PACKAGE

ab Name: LIONVIEIE_LAEORATORY

Contract: $\quad 60052-1$

ab code: IVII_ case No: V1386 sas no.:

SDG No.: VOI.

2W No. : 5 WR 46

EPA sample lo.

$\mathrm{VO1}$

-102
-703

- $703 \overline{\mathrm{D}}$

- 035

VO4

$-405$

- 106

$-706 \bar{D}$

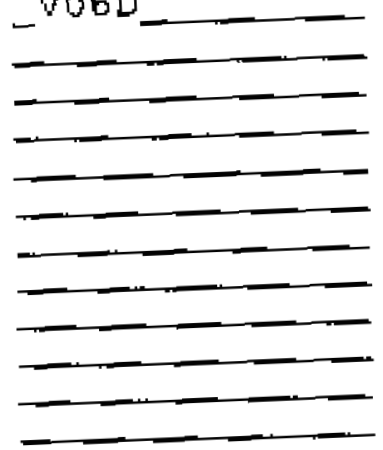

Lab Sample ID

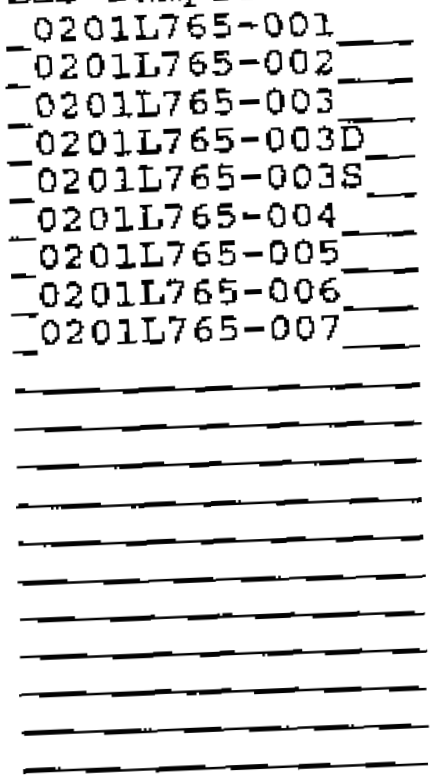

ere IcP interelement corrections applied ?

YQS/NO YES

zre IfP background corrections applied ? If yes - were raw data generated before application of background corrections?

Yes/ $/$ NO YES

YeS/NO NO

Jmments:

certify that this data package is in compliance with the terms and nditians of the contract, both technicaliy and for completeness. for her than the conditions detailed above. Felease of the data containea this hardopy date package and in the computer-readable data submitted

"i flopy diskette has been authorized by the Laboratory lanager or the nager's designee, as Yerified by the following signature.

ignature: te:

$$
01-16-0
$$


1

INORGANIS ANALYSES DATA SHEET
Lab Name: L.IONVILIE_LABORATORY

Lab Code: LVII

Matrix (soil/water) : soIL

Lrevel (low/med):

golids:

$$
\begin{array}{r}
\operatorname{LOW}^{+}- \\
97.3
\end{array}
$$

Contract: $60052-1$

SAS No.:

I $\overline{\text { ab Sanple ID: } 02011765-00}$

Date Received: 01/11/02

Concentration Units (ug/L or mg/kg dry weight): MG/KG

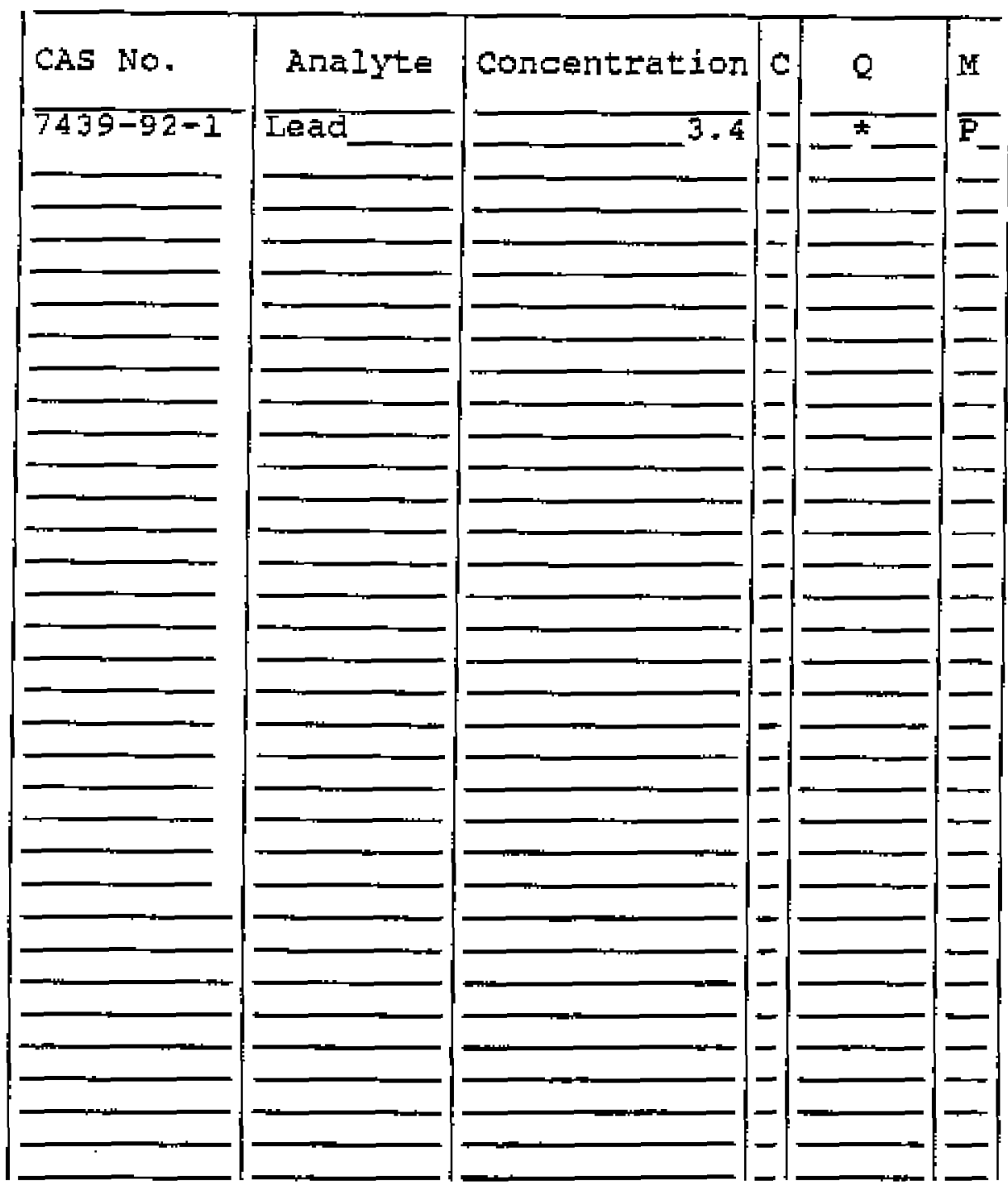

Solor Before:

color After:
EPA SARPLE NO.

Vo1
Clarity Before:

clarity After:
Texture:

Artifacts:

\section{Jomments :}

CAU143 PB-VO1 
U.S. EPA

1

\section{INORGANIC ANALY'SES DATA SHEET}

Iab Name: I.IONVILLE IRBORATORY

Lab code: IVII

Natrix (soil/whter): soII-

Level (10w/med) :

o solids:
IOW

$9 6 \longdiv { 7 }$
Contract: $60052-1$ SAS No.:

Lab SampIe ID: $0202 \mathrm{~L} 76 \overline{5-002}$

Date Received: $01 / 11 / 02$

Concentration Units (ug/L or ng/kg dry weight): MG/KG

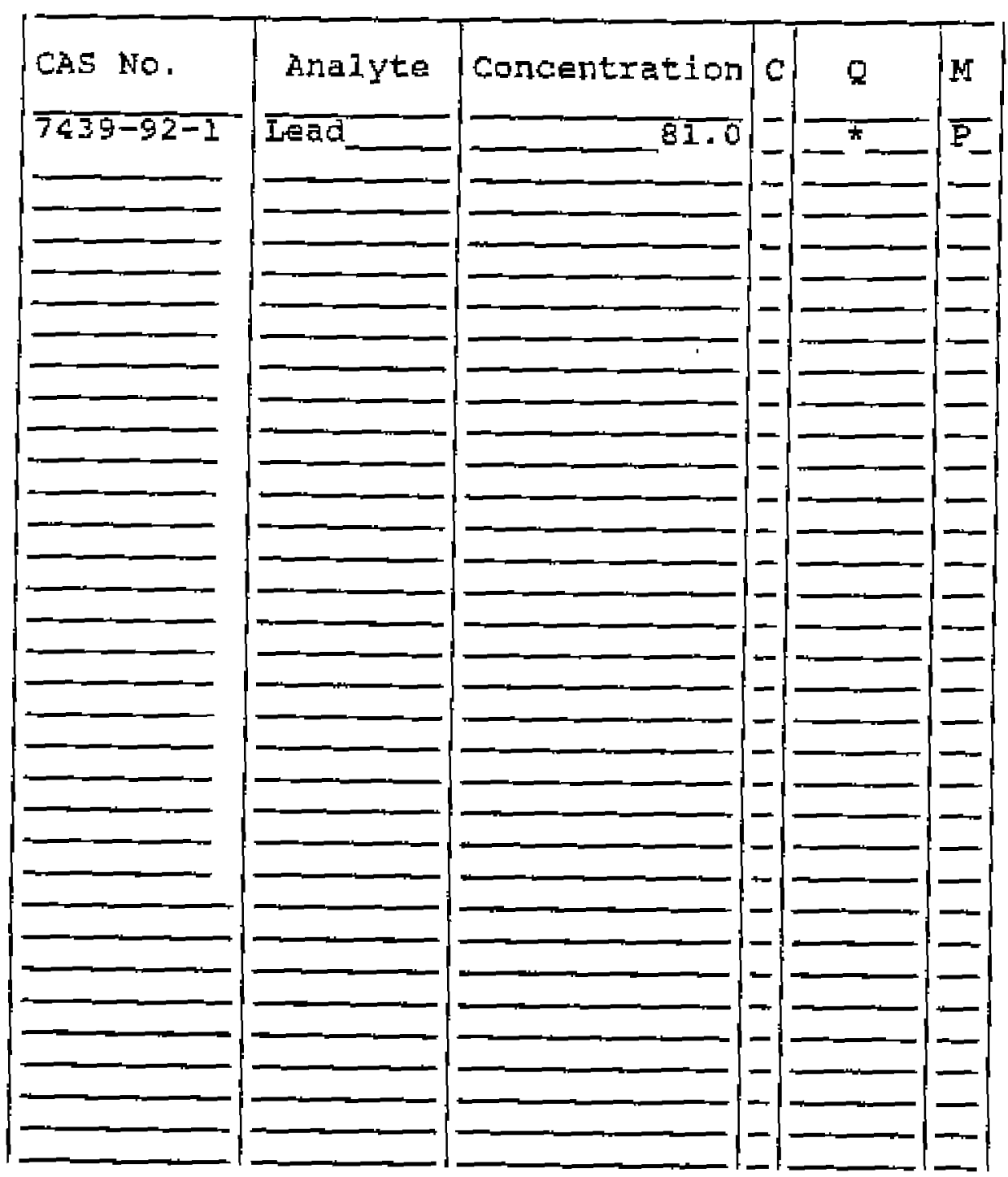

Olor Before:

olor Atter:
EPA SAMPIE NO.

\section{Vo2}


1

INORGANIC ANALYSES DAFA SHEET
EPA SANPLE NO.

\section{Vo3}

contract: $60052-1$

SAS No: : Lab Sample ID: 0201I7E5-06. Date Received; $01 / 11 / 02$
Lab Name: ISON

Matrix (soil/water): soli_

Levei (low/med):

golids:

$$
-\frac{\operatorname{Low}}{97.6}
$$

Case No:: VI 388

concentration Units (ug/L or $\mathrm{mg} / \mathrm{kg}$ dry weight) : MG/KG

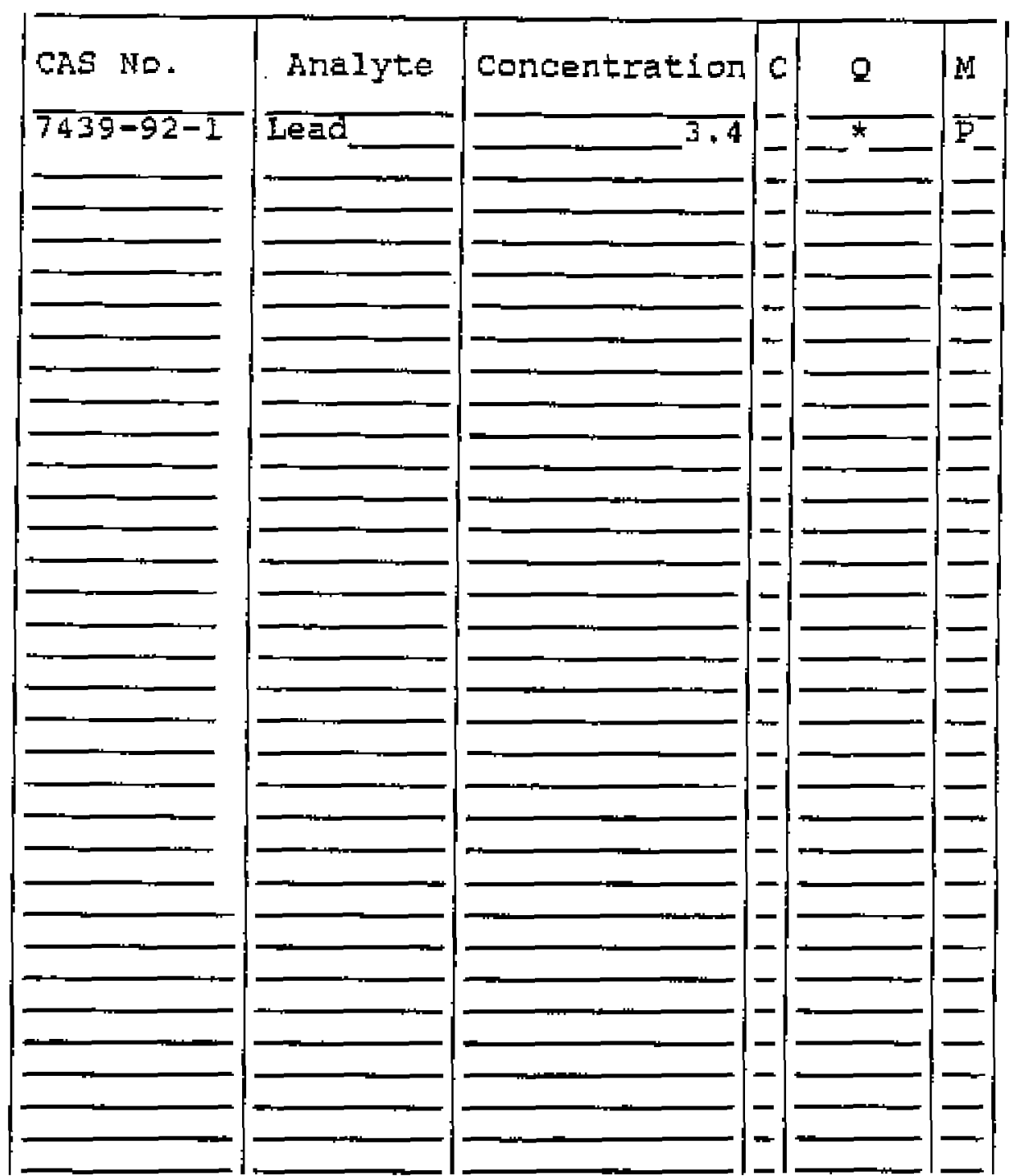

Clarity Before: Clarity After:
Texture: Artifacts:
Colar Betore:
Solor After:

\section{-oliments:}

CAU143 $\mathrm{PB}-\mathrm{VO}$ 
Lab Nane: LIONVILIE LABORATORY Lab code: IVLI Matrix (soil/water): soIILeve] ( $10 \mathrm{w} /$ med) : solids:

$$
\operatorname{Low}_{-96.2}
$$

contract: 60052-1

SAS No.: IAB Sample ID: 0201L765-004 Date Received: $01 / 11 / 02$

Concentration Units (Lg/L or mg/kg dry weight): MG/KG

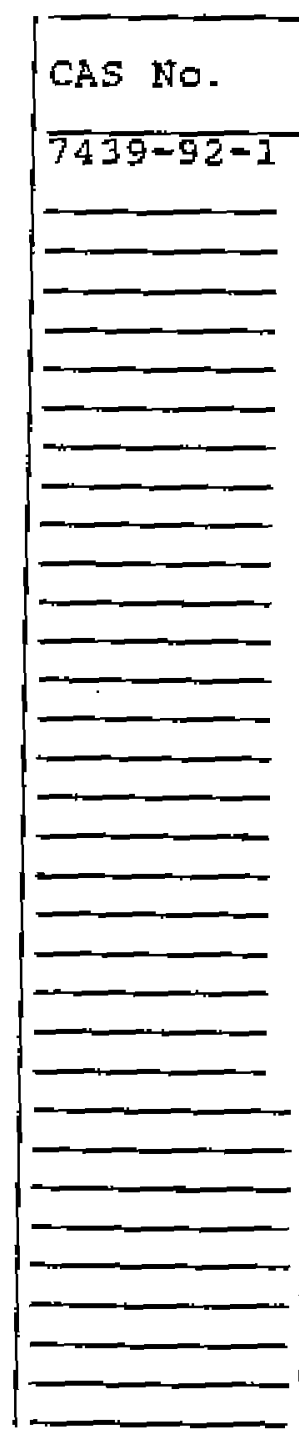

- olor Before: olor After:

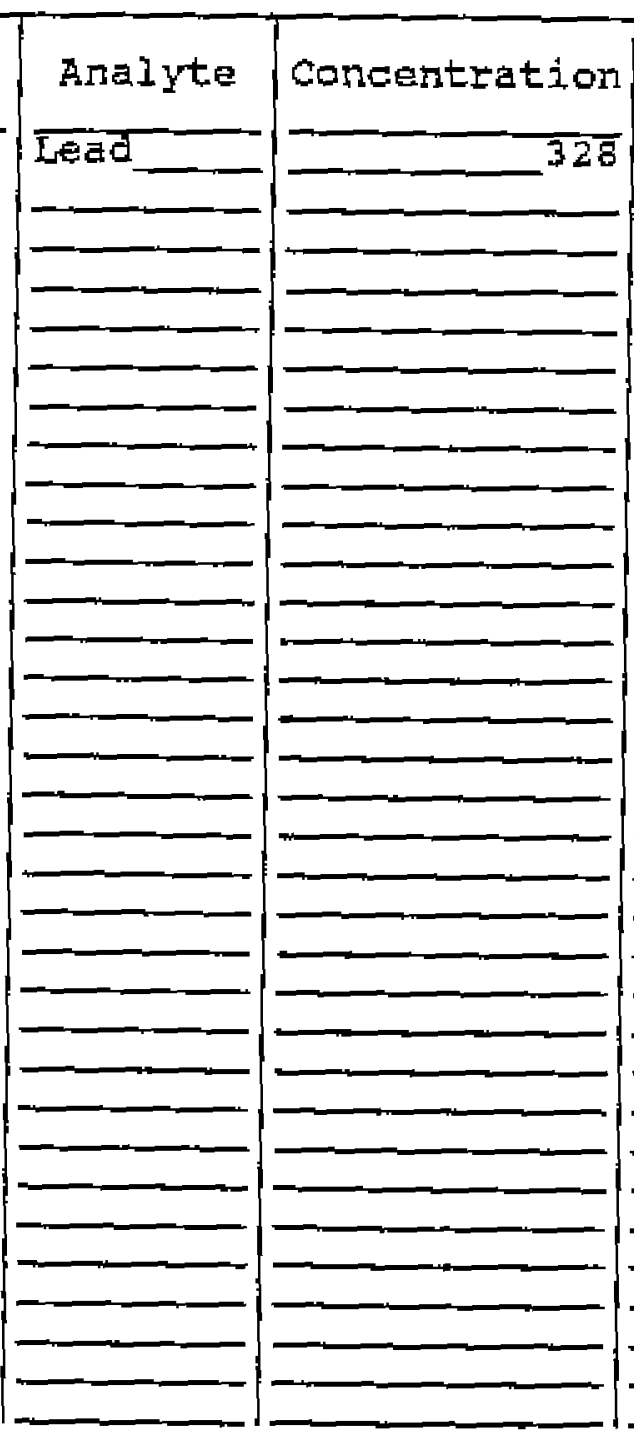

Clarity Before: Clarity After:

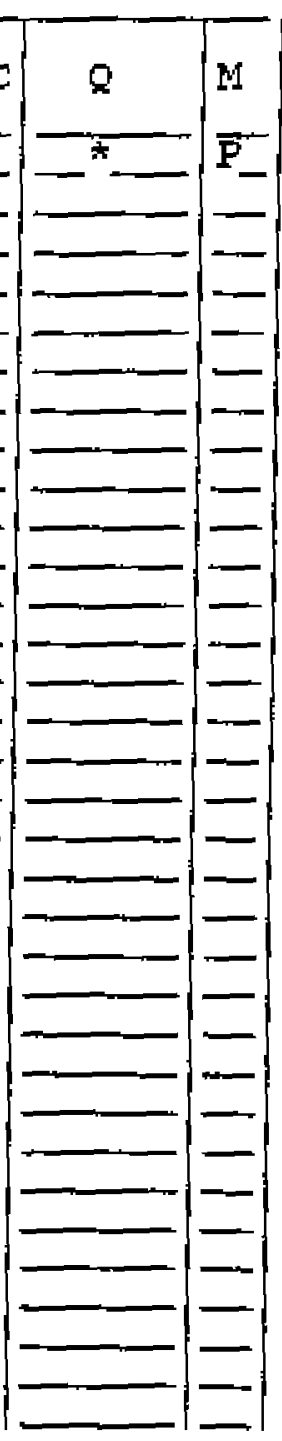

Texture: Artifacts:

\section{Cominents:}

\section{$\mathrm{CHU} 14 \mathrm{FB}-\mathrm{VO} 4$}


1 INORGANIC ANALYSES DATA SHEET
Lab Name: IIONVILLE IABEORATORY Lab code: LVII Matrix (soil/water): solI. Level (low/med) : golids: Contract: $60052-1$
SAs No.:

SDG No: VOT

EPA SARPLE NO.

$\operatorname{Vos}$

Iab Sample ID: 0201L765-0 Cs

Date Received: 01/11/02

\section{Concentration Units (ug/I or mg/kg dry weight): MG/KG}

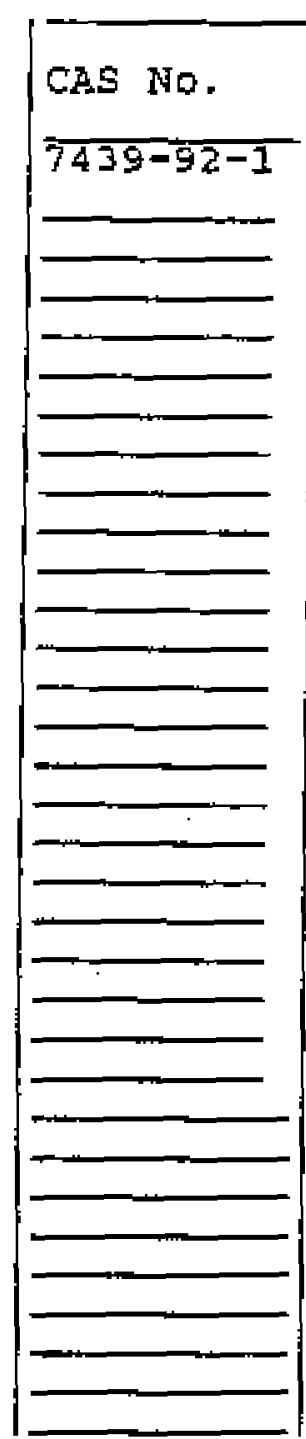

vlor Before: solor After:

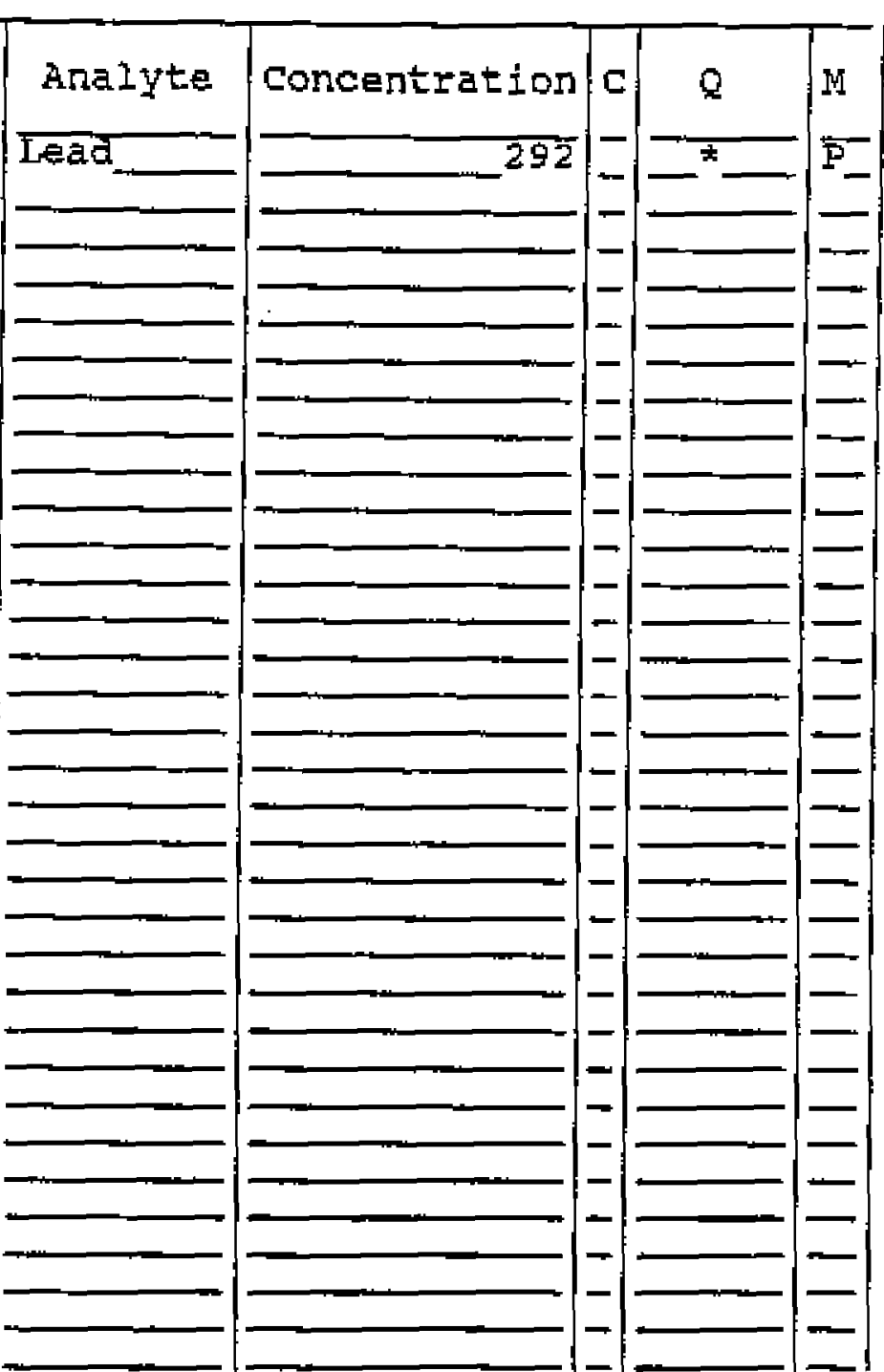

Clarity Before: Clarity After:
Texture: Artifacts:

\section{sminents:}

CAU143 PE-VOS 
U. S. EPF

1

INORGANIC ANALYSSES DATA SFEET
EEA SARFLE MO.

Yo6

Lab Name: LIONVIIIE_ LABORATORY Lab code: IVII Matrix (soil/water): soIL_ Level (low/med): IOW solids:

Contract: $60052-1$ SAs No.: Lab Sample ID: 0201I765-606 Date Received: $01 / 11 / 02$

\section{concentration units ( $\mathrm{Hg} / \mathrm{L}$ or $\mathrm{mg} / \mathrm{kg}$ ary weight): Me/KG}

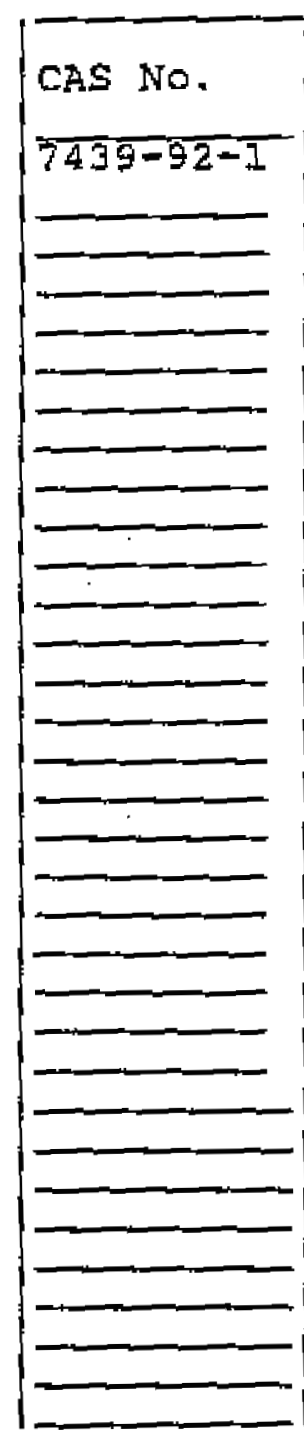

:olor Before: olor After:

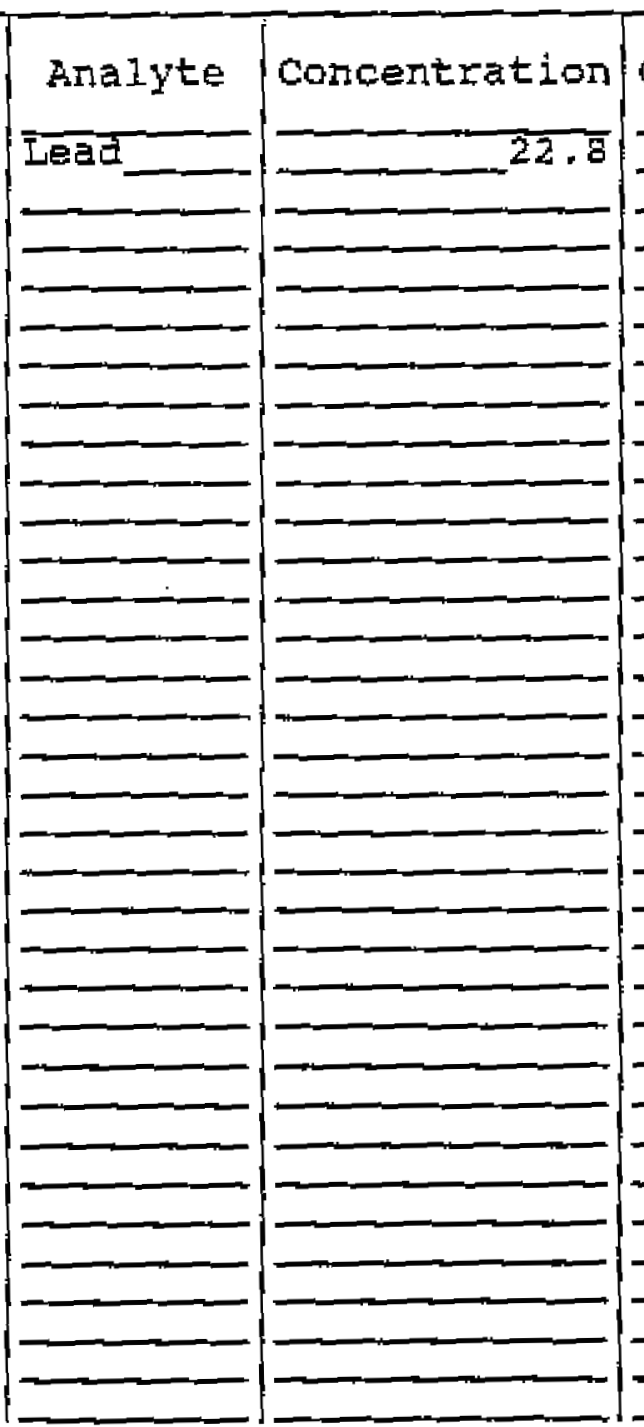

Clarity Before: clarity After:

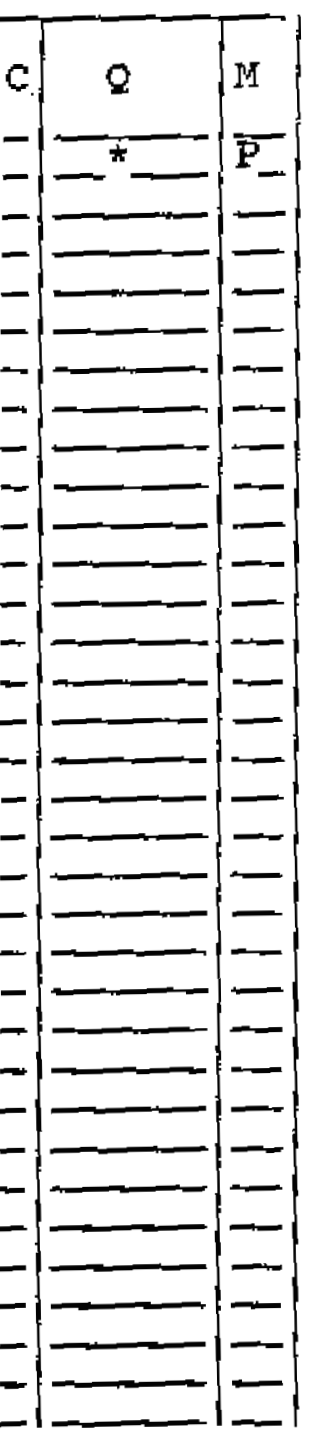

Texture: Axtifacts:

\section{comments:}

CAO143PB-V06 
EFA SAMPLE NO.

Iab Nane: IIONWILIE_LABORATORY

Lab code: LVL.I

Matrix (soil/water): soIL

Level (low/med):

of solids:

EOW
-96.9

Contract: $60052-1$

$706 \mathrm{D}$

Concentration Units (ug/L or $\mathrm{mg} / \mathrm{kg}$ dry weight): $\mathrm{MG} / \mathrm{KG}$

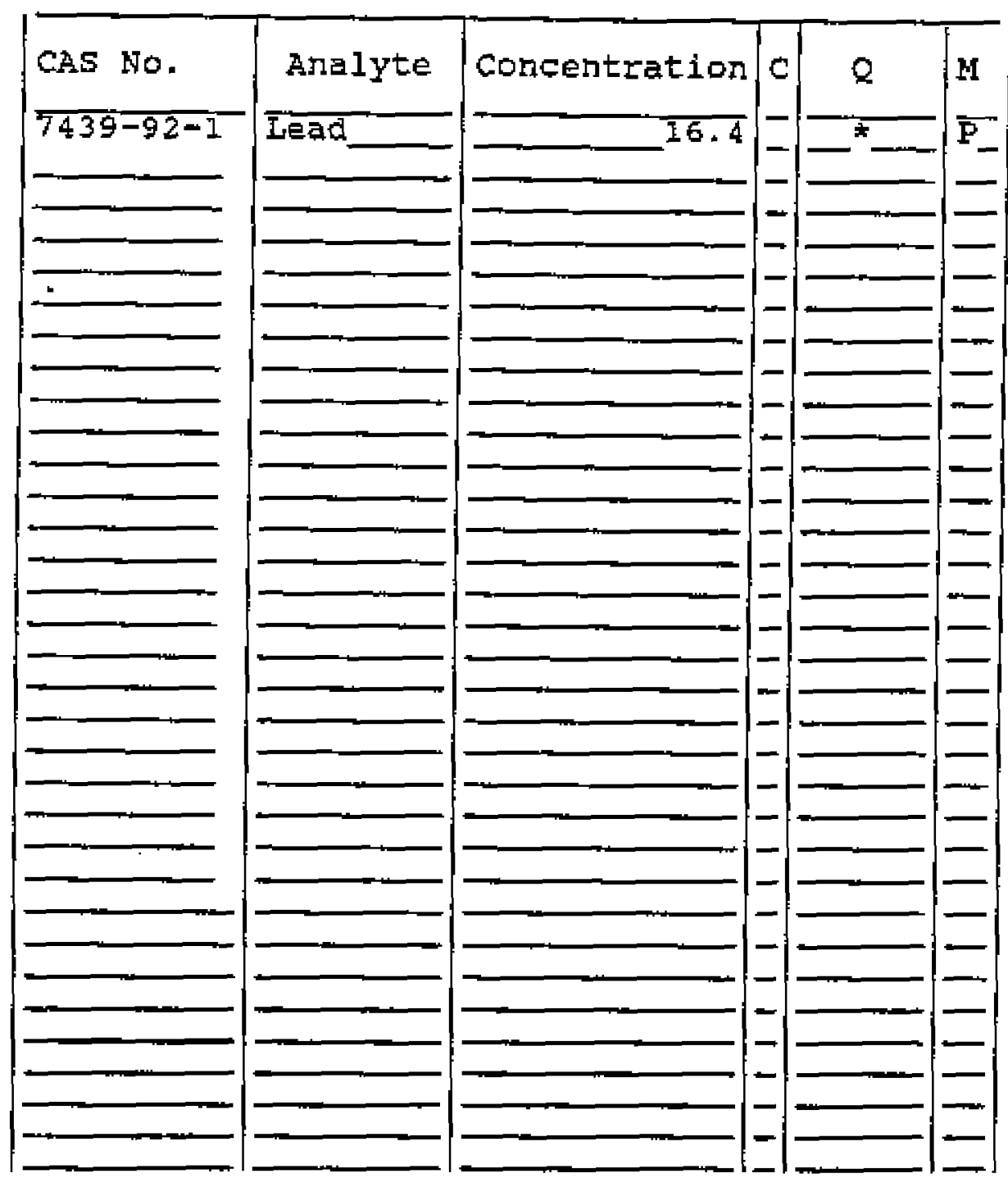

Color Before:

Color After:
Clarity Before:

Clarity After:
SDE IHO:: VOI

Lab Sample ID: 0201I765-6 J7

Date Received: 01/11/02

SAS NO.:

Comments:

CAU143 PB-VO6D 


\section{APPENDIX C}

\section{CAU 143 GLOBAL POSITIONING SYSTEM COORDINATES FOR GEOPHYSICS MARKINGS}




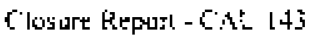

5ection: Apothdic

Kex

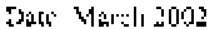

THIS PAGE INTENTTONALLY LEFT BLANK 
CAL 143 GPS Coordinates for

Geophysics Markings

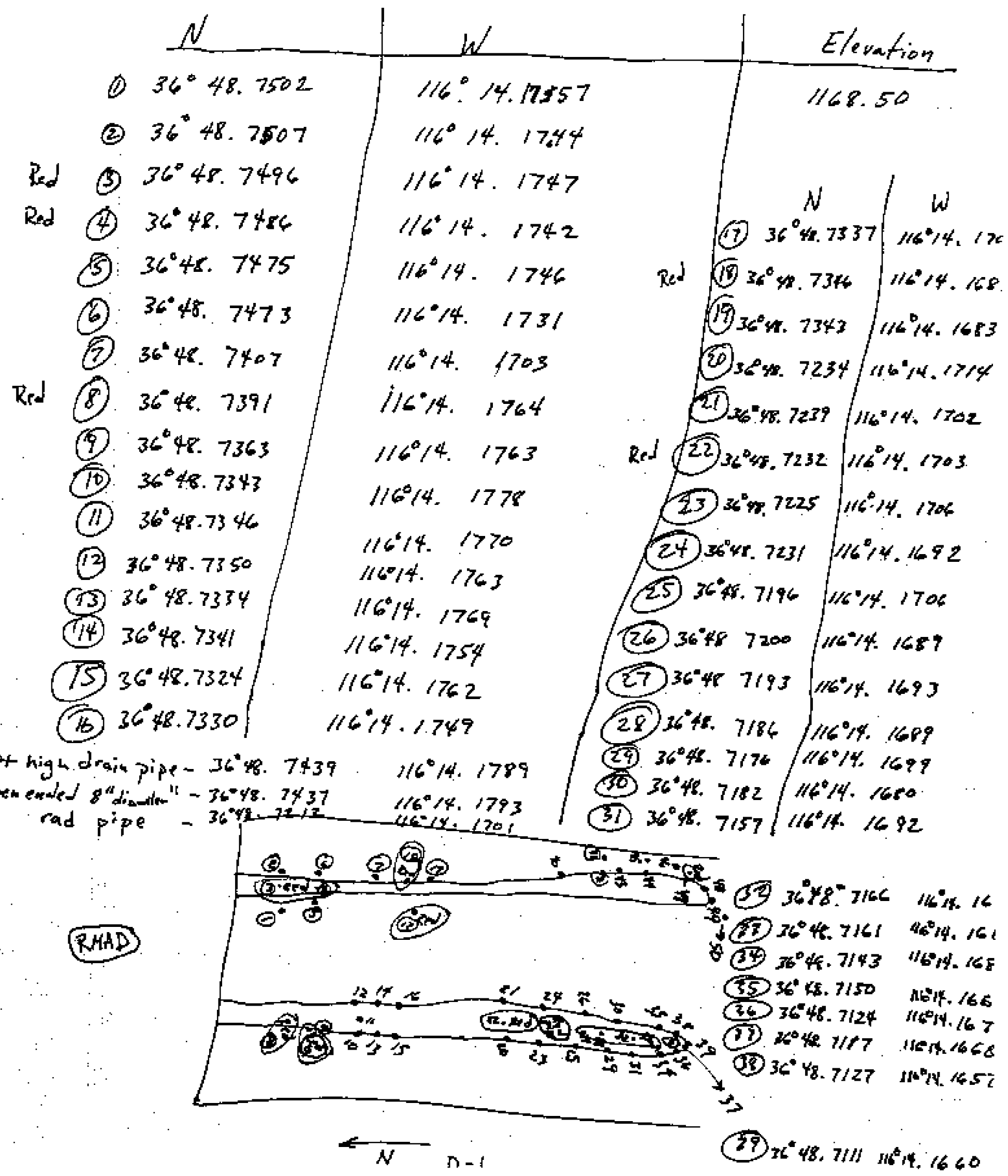


(40) $36^{\circ} 48.7230$

(क) $36^{\circ} 48.72 .07$

(42) $36^{\circ} 48.7211$

(43) 76.48 .7205

(44) $36^{\circ} 48.7185$

(45) $36^{\circ} \% 8.7186$

(40) $36^{\circ} 48.7 / 43$

Red (47) $36^{\circ} 48.7138$

(48) $36 * 48,7 / 15$

(49) $36^{\circ} 45.7106$

(50) $36^{\circ} 48.7095$
W

$116^{\circ} 14.1639$

$116^{\circ} 14.1625$

$116^{\circ}, 4.1605$

$116^{\circ} 14.1617$

$116^{\circ} / 4,16 / 2$

$116^{4} / 4.1598$

$1 / 6^{\circ} / 4.158 \mathrm{~F}$

$116^{\circ} / 4 \cdot 1583$

$116^{\circ} / 4.1581$

$116 \% 4.1580$

$116 \% 4.1601$

$D-2$ 


\section{CAU 143 RADIATION SURVEY REPORTS}




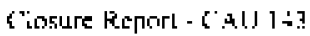

Sect'DI. ApP:In: $[1$

Revisint 11

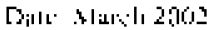

THIS PAGE NTENTIONALLY LEFT BLANK 
Bechtel Nevada

RADIATION SURVEY REPORT

Number 23688

Page $/$ of 1

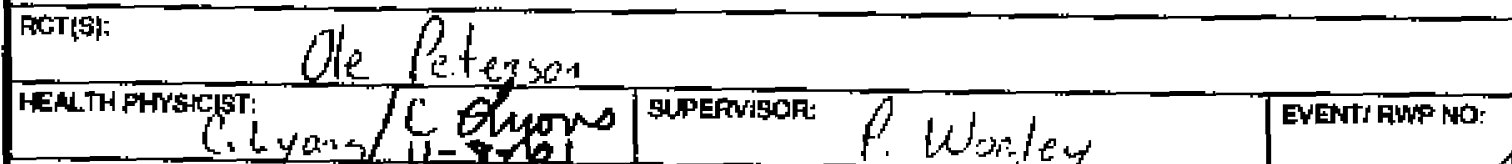
SHGMATURE:

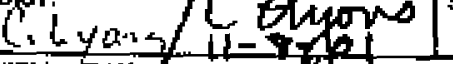
GOUNTING ER

NSTRLMENT CODFFing

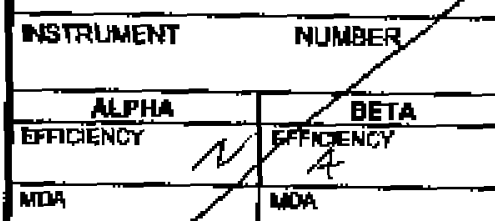

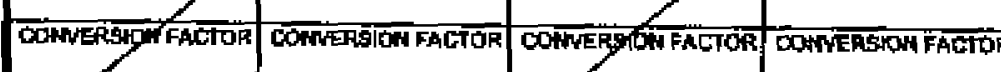

coyf TIME INSTRUULENT

\section{EQU JPHENT USEO} Nhinigar

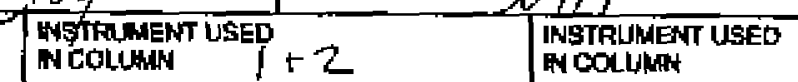
INSTRUMEMT NAMMER Electra $/ 193$

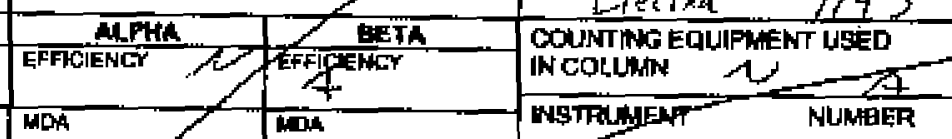
Nons

Puppose Byst Time

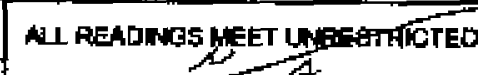
RELEASETHITS? H.

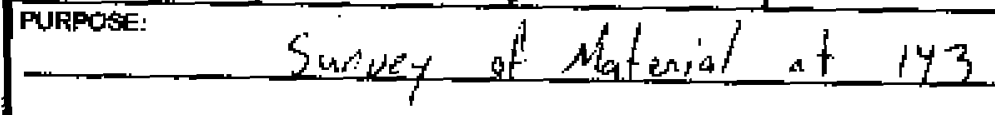

\section{TIME DESCRIPTION OF SURVEY}

I5OO BACKGROUND (GTOSs)

- Mis. Eree fosts Misi Signa Metal Meral Frawe

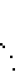
lust Itrom

\section{CONMENTS: \\ $2701+4$}




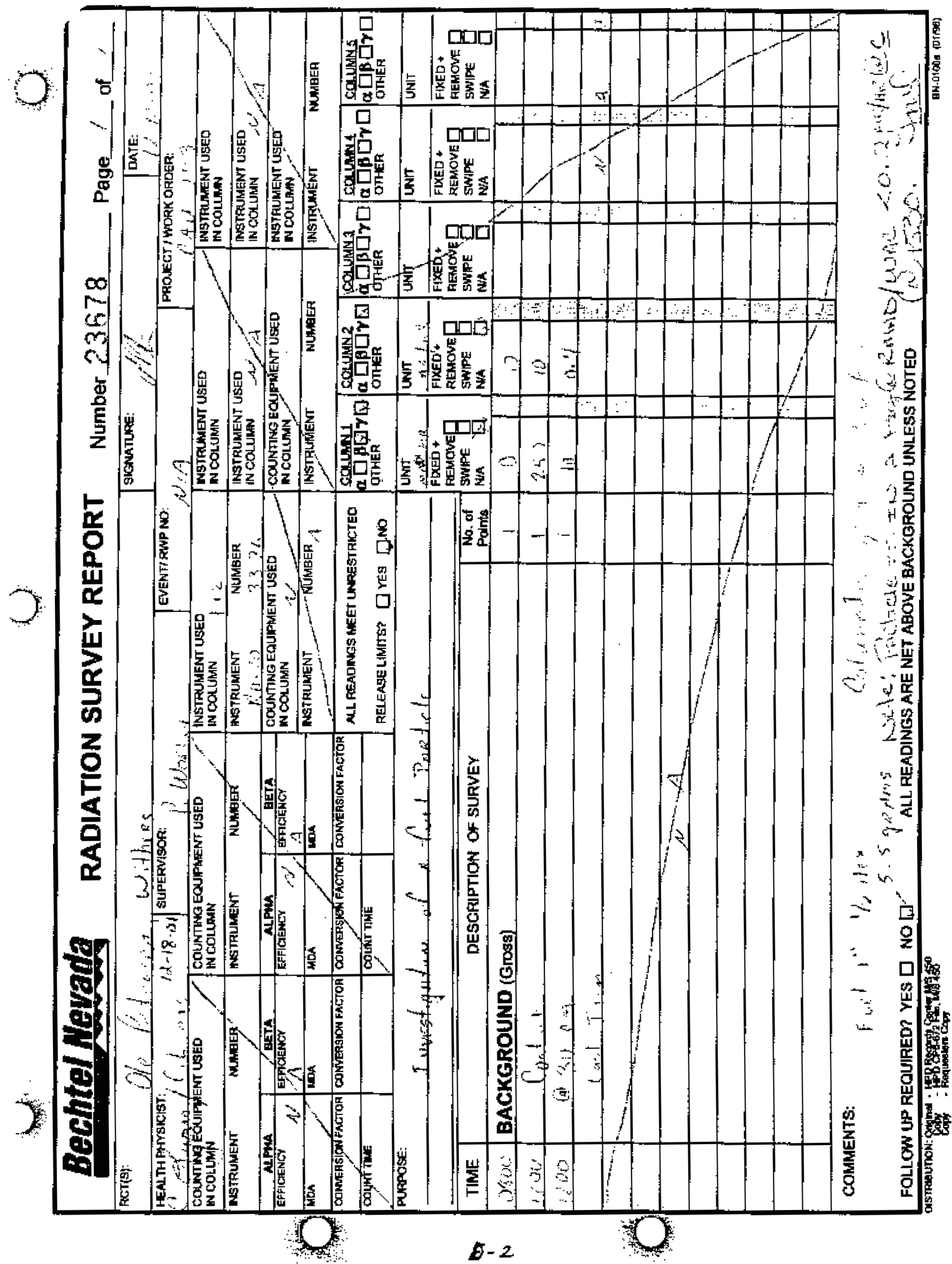




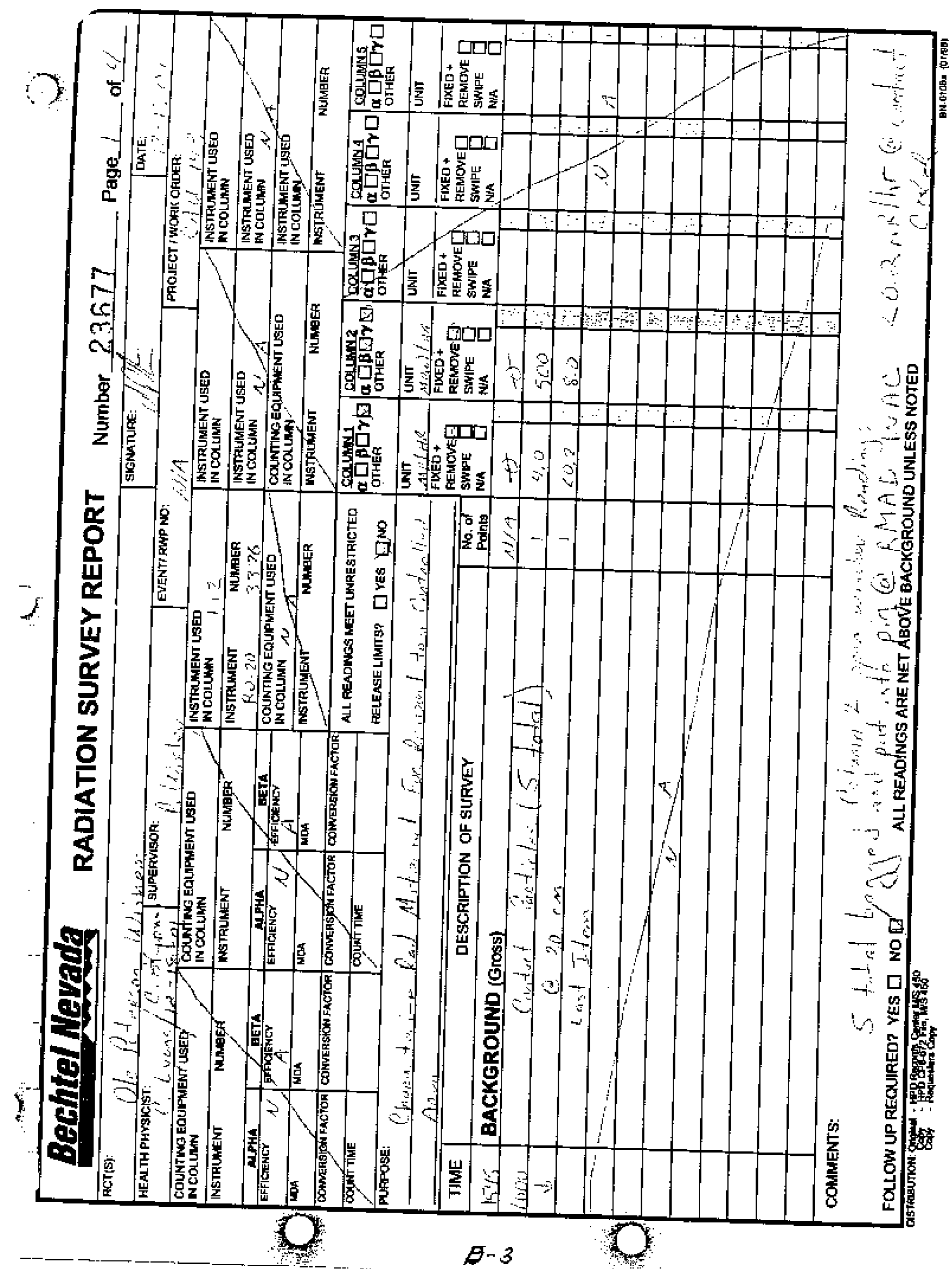




\section{Bechtel Nevada}

RADIATION SURVEY REPORT Number_23689

(x) ole pletenion

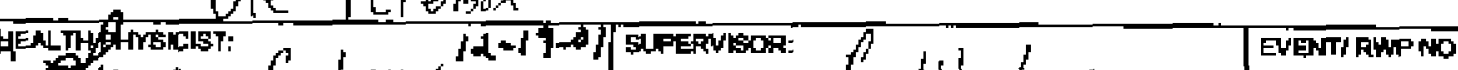
SICMATUAR:

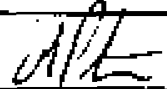

Quma C.Lyens Colo COUNTIMG EOUFAENT USED $/$ WISTANENT USED

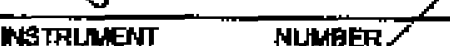

W CoLUhN $1+2$

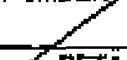

IMSTFUMENT

NuWEER

MSTRU; MNT MARER Electar 3500

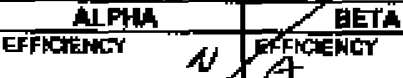
ALPH

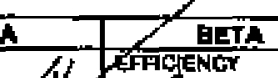
COENTEG EOUPNENT USED nom Man

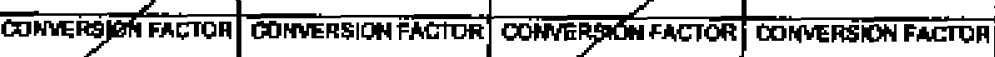
collot in

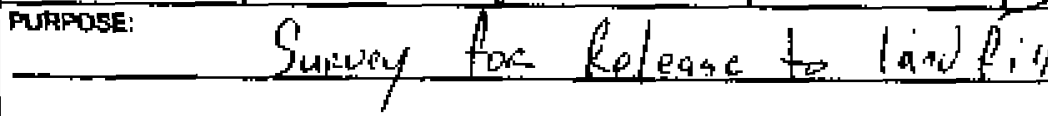
MSTEUANENC) 19

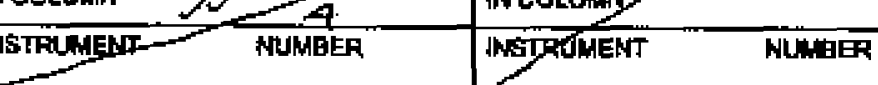
Page 1 of 1 $2 \rightarrow$

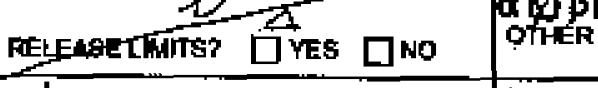

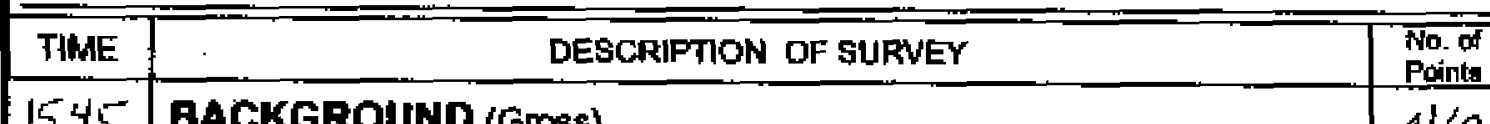

1545 BACKGROUND (Gross)

1550 Metal Frame

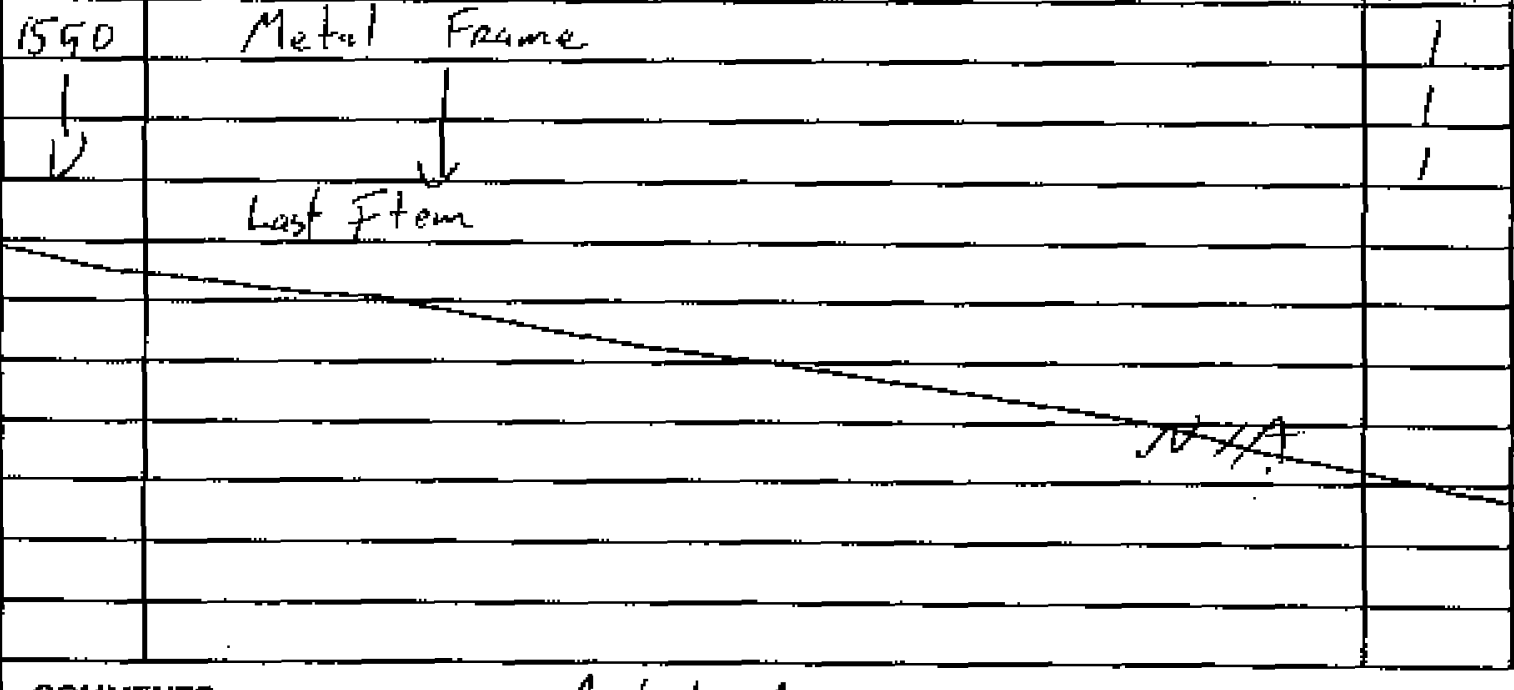

(2) N GOLIMN
Wh

MLSTRIMENT UDED NoOLun

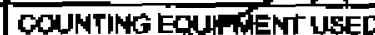
WN COLUAM 1

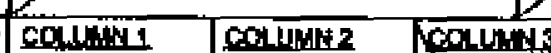
TSSTRUTHENT USED IN COLUMN $-\mathrm{C}$

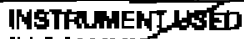
WoOLuhH RSJRCMENT OATE: $29-49-01$

commEnts: Luggen $A_{\text {osfed }} R A$

FOLLOW UP REOUARED? YES WO NO $\square$ ALL READINGS ARE NET ABOWE BACKGROUHD UNLESS NOTED 
FCT

Th

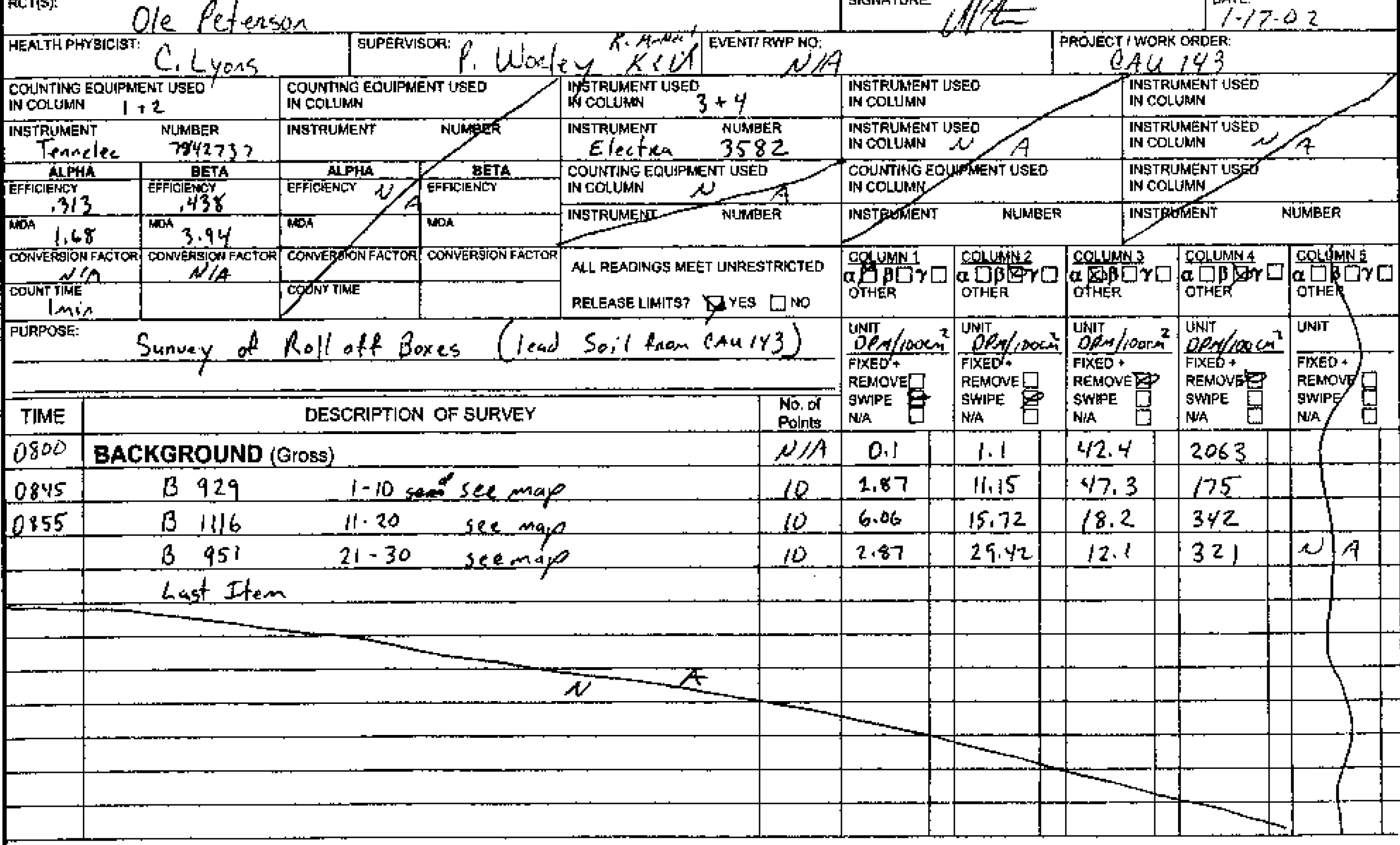

COMMENTS: none

FOLLOW UP REOUIFEC? YES $\square$ NO \& ALLL READINGS ARE NET ABOWE BACKGROUNND UNLESS NOTED 
RADIATION SURVEY REPORT

Number $02-A 25-033$ Page 1 of 3

ACTis: ole fetenson

HEALTHPATSECIST: $l$. Lyons.

COUNTING EOAIFMENT USE

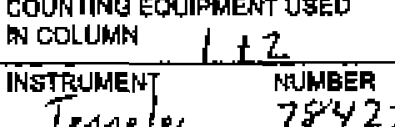

Teraeles 7842732

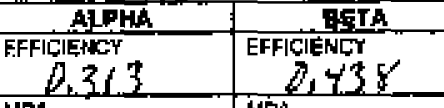

ts

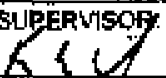

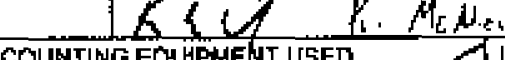

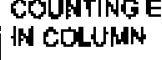

INGSTIUMENT

MDA $(168) 3.94$

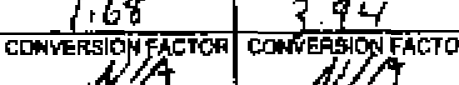

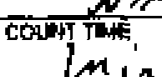

Lain

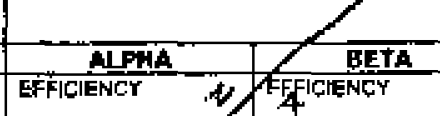

BETA

$4+5$

HDA

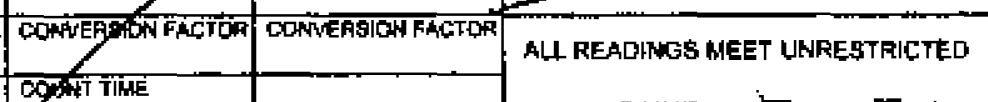
AELEASE LMITS7 YO YES 口W PIJPFOSE:

Sumesy of (Exply) Rolloll Boxétio

\begin{tabular}{|c|c|}
\hline \multicolumn{2}{|c|}{$\begin{array}{l}\text { INISTRUMENT USED } \\
\text { IN COLUANA } 3+4\end{array}$} \\
\hline 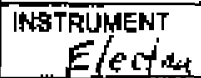 & N/2\% \\
\hline
\end{tabular}
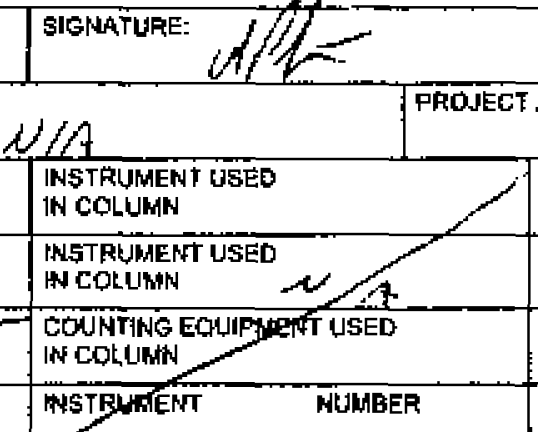

NOFH ORDER:

DATE: CAU/Y

UESTRUMANT USED

IN COLLHAN

INSTSTHWENT USED

IN CoLUhN USEO

INSTRIBHEEIJ SED

IN COLUyH

INGSTUWENT MURAEER

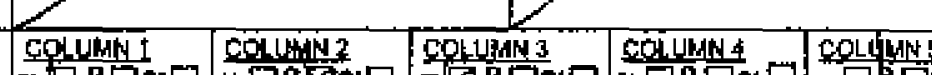

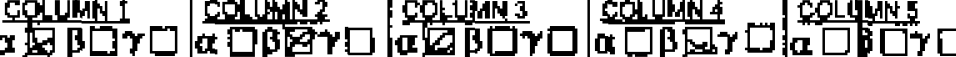

OTHER T DTHER DTHER

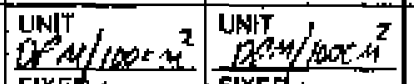

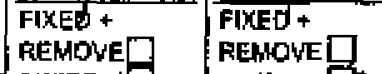

\begin{tabular}{|c|c|c|}
\hline TIME & DESCRIPTION OF SURVEY & $\begin{array}{l}\text { No. or } \\
\text { Polnts }\end{array}$ \\
\hline 0850 & BACKGROUND (Gross) & $N / 4$ \\
\hline 0900 & B544 (See Mapp) & 10 \\
\hline
\end{tabular}

SWIFE $Q$ SUWPE

OTHEF

DNA $\square$ W

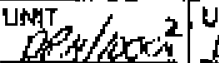

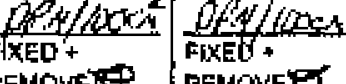

REMONET

SWhPE

REMOWEEI

SWIP

Wh

\begin{tabular}{l|l|l|}
$1 / 4$ & 0.1 & 1.1 \\
10. & 0.0 & 15,12 \\
\hline
\end{tabular}

38.2

$2 / 64$

Last Iten

COMINENTS:

rione 


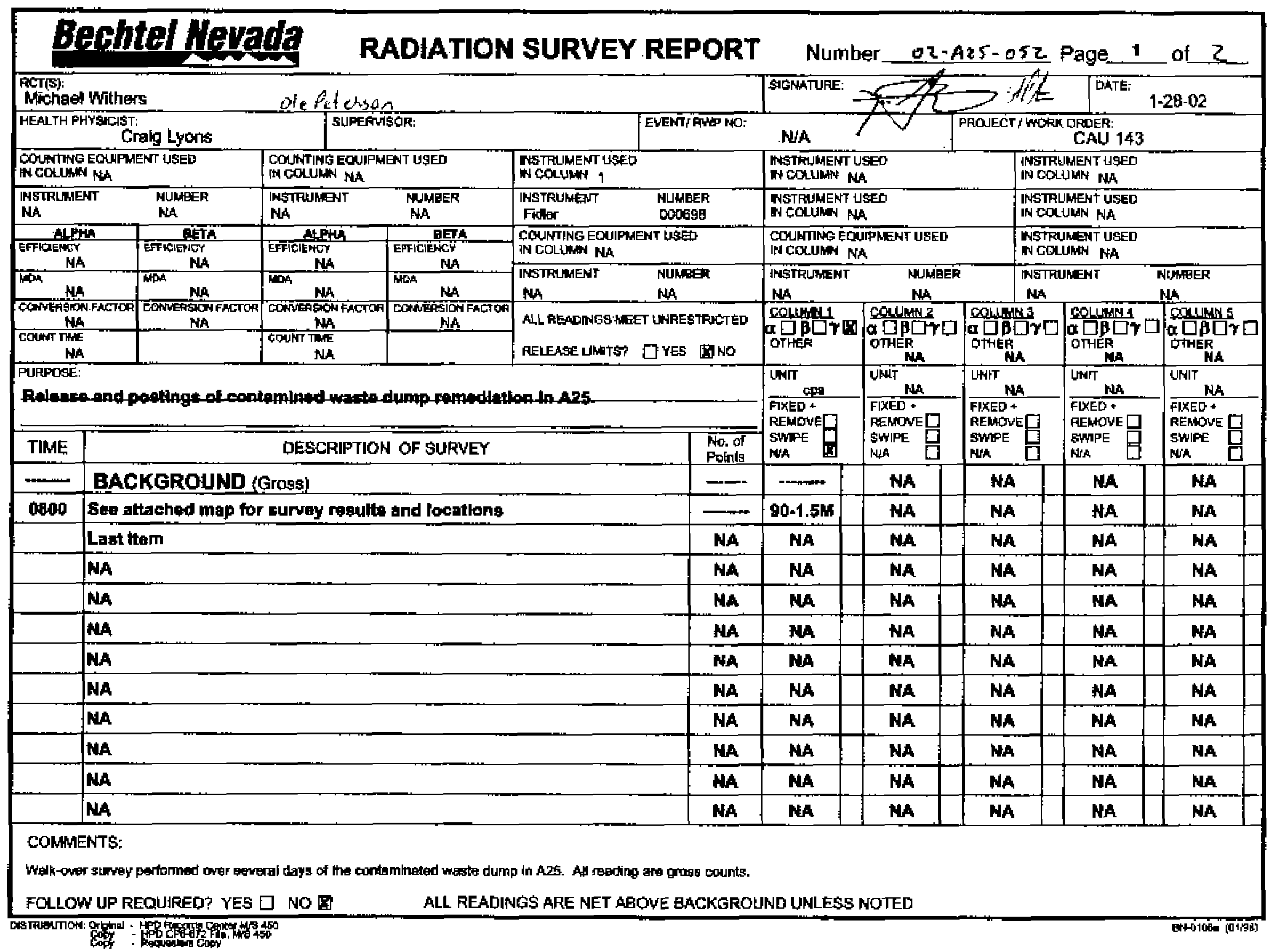




\section{NOILVINYOANI NOILOIYLSHY HSA E†I AVD}

\section{T XIQNGddV}


bus: staxch Ion? 


\section{CAU Use Restriction Information}

CAU Number:Description: CAU 143: Area 25 Contaminated Waste Dumps

Applicable CAS Numbers/Descriptions: CAS 25-23-09Contaminated Waste Dump\#1:and

CAS 25-23-03, Contaminated Waste Dump\#2

Contact (Organization/project): DOE/NY Industrial Sites Pro:ect Manager

Surveyed Area (LTM cootdinates; Zone 11, NAD 27): R-MAD and E-MIAD

The site is defined by the following $\mathrm{NAD} 27$ cootdinates:

R1 36.488473,-116.141429 4074328.21+Northing 568248.56-Easting-R-MAD

R2 36.488263,-116.141168 4074289.70-Northing 568287.67-Easting - R-MAD

R3 36-488096, -116.140620 4074259.47-Northing 568369.38-Easting - R-MAD

R4 36.487394,-116.140323 4074130.04-Northing 568414.57-Fasting-R-MAD

R5 36.486956,-116.142033 4074047.02-Northing 568161,01-Easting-R-MAD

R6 36.487772, -116.142550 4074197.28-Northing 568082.95-Easting-R-MAD

R7 36.487952, -116.141854 4074231.38-Northing 568186.15-Easting-R-MAD

$\underline{\text { R8 36.488409, }}$-116.142046 $4074315.65-$ Vorthine 568156.94-Easting-R-MAD

R9 36.488461,-116.141838 4074325.51-Northing 568187.58-Easting-R-MAD

R10 36.488378, -116.141555 4074310-50-Northing 568229.97-Easting - R-M1AD

R11 36.482823,-116.184032 4073235.34-Northing 561923.02-Easting - E-MAD

R12 36.482808, -116.183921 4073232.68-Northing 561939.55-Easting - E-M1AD

R13 36.482676, -116.183952 4073208.24-Northing 561935.]1-Easting - E-MLD

R14 36.482695, -116.184068 4073211.63-Vorthing 561917.84-Easting - E-MAD

Survey Date: February 5,2002 Survey Method (GPS, elc.): GPS

Site Moniloning Requirements: Visual Inspections.

Required Frequency (quarterly, annually?):Annually

Ir Monitoring Has Started, Indicale Last Completion Date: N/A 


Use Restrictions
The future use of any land related to this Corrective Action Unit (CAU), as
described by the above surveyed location, is restricted from any DOE or Air
Force activity that may alter or modify the containment control as approved by
the state and identified in the CAU Closure Report or other CAU documentation
unless appropriate concurrence is obtained in advance.

Comments: See the Closure Report for additional information on the condition of the site and any inspection requirements.

Submitted By:

Attachments: Survey Map:

CAU Files (2 copies) 


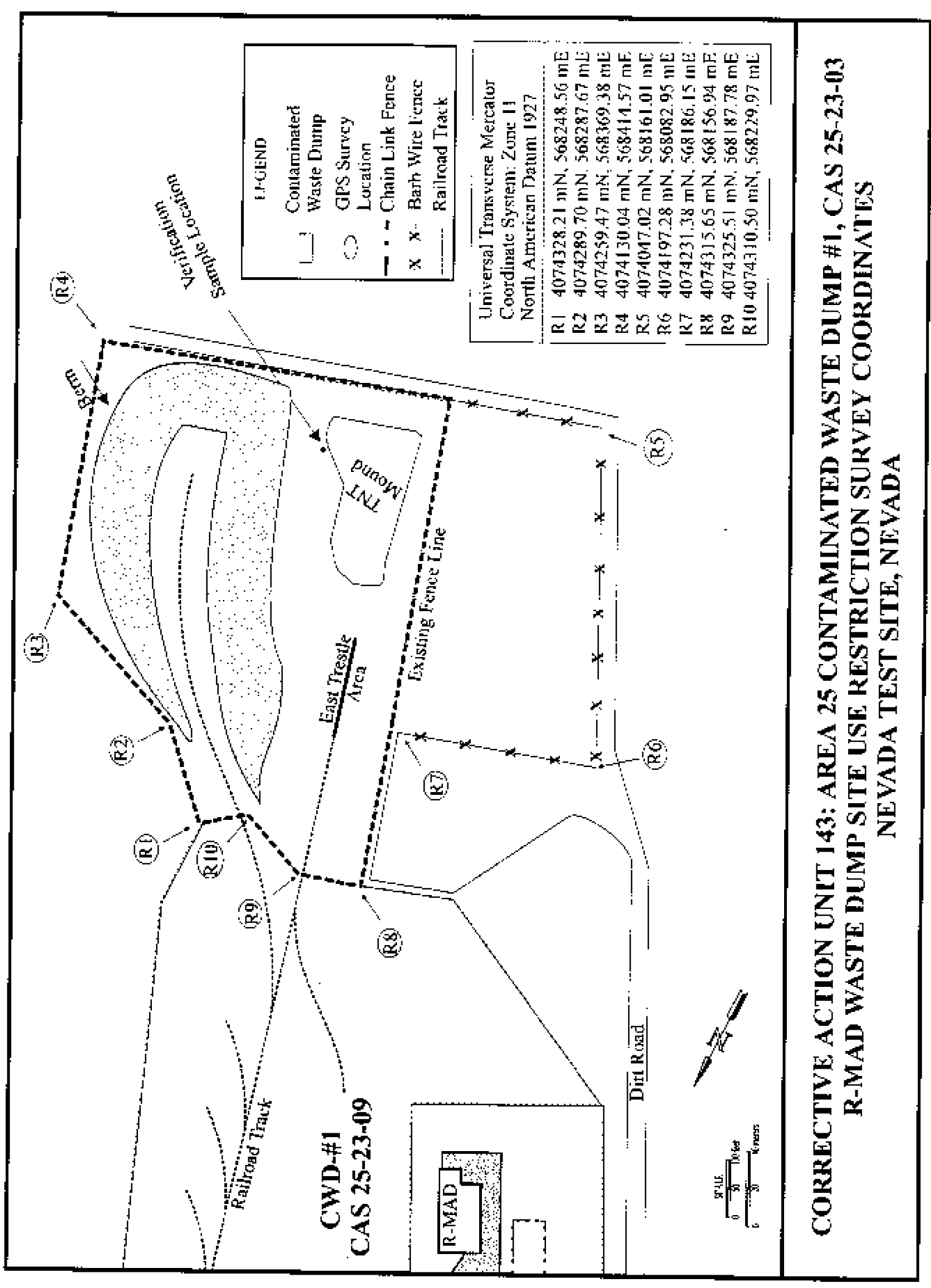




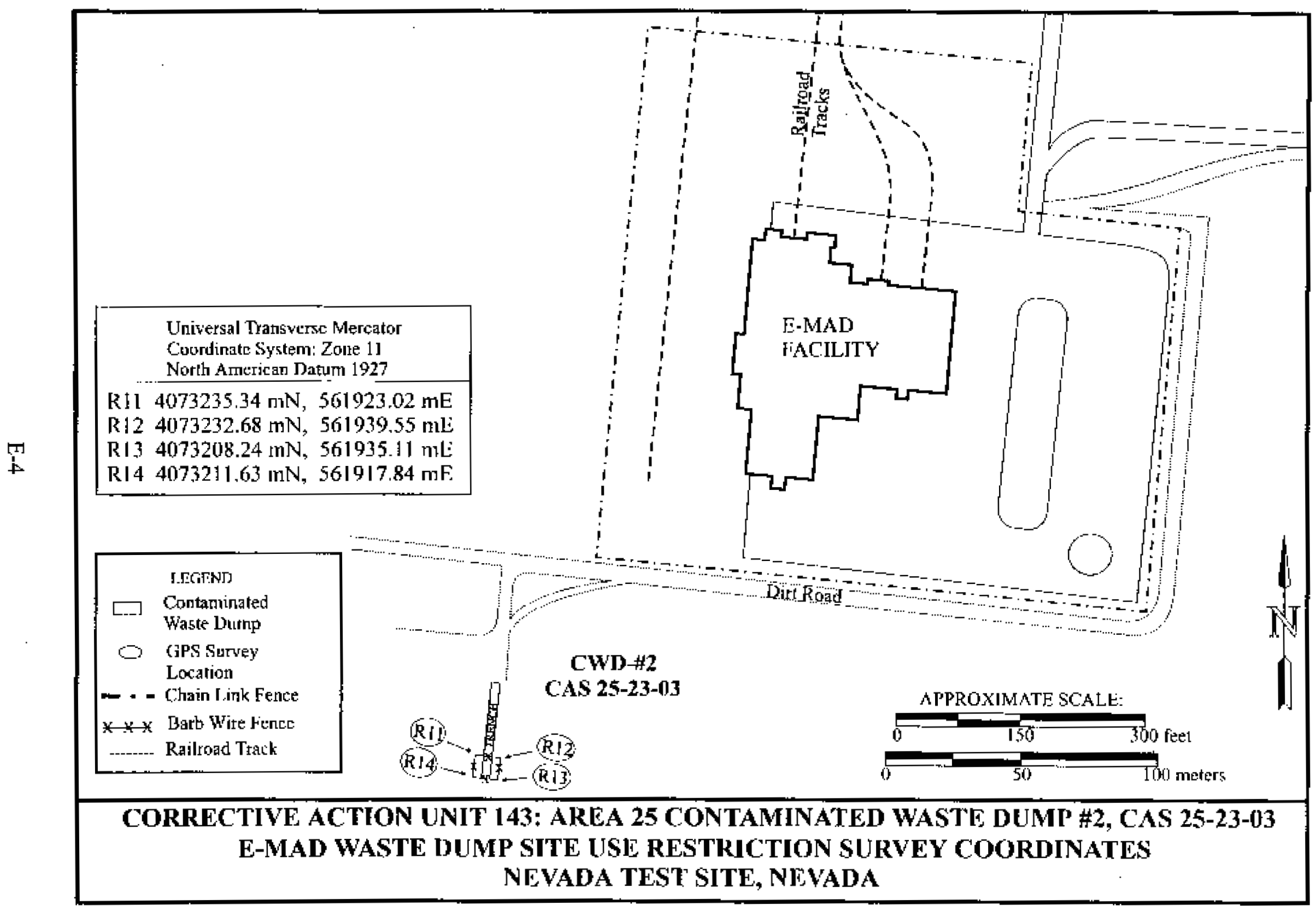




\section{NOLLVINGWDDOA NOILISOdSI HLSVM E†I ПVD \\ H XIONHddV}


Gosire Repat - CSL I-

Së̈lun: Appenti r F

Rin'

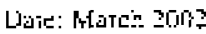

THIS PAGE INTENTIONALLY LEFT BLANK 


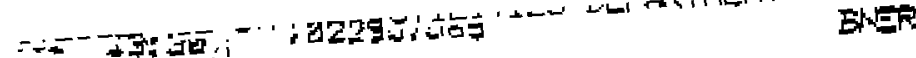

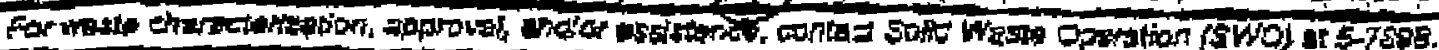

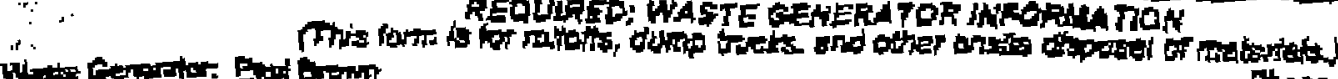

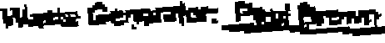

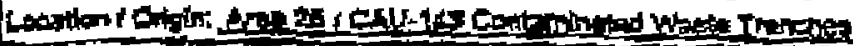
Want catyrorti (eheak one)

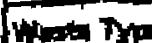
$t \rightarrow=x+\infty$ 1 KT: Logntreatid

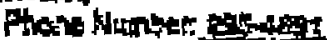

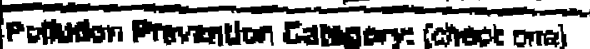

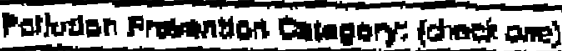

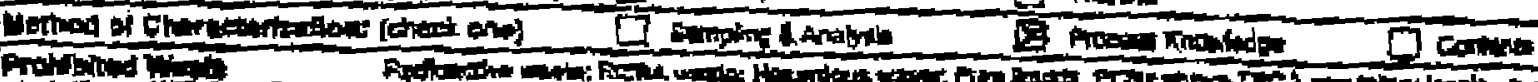

D Paranow D 7 industin

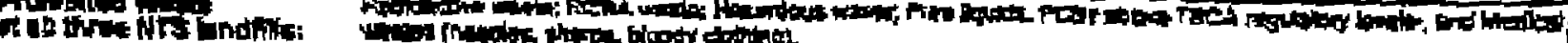

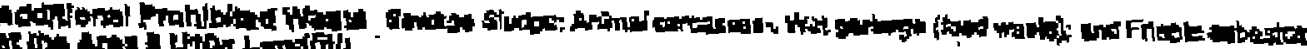

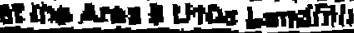

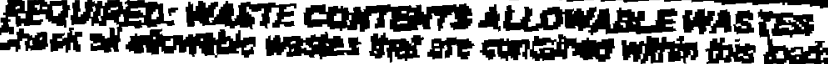

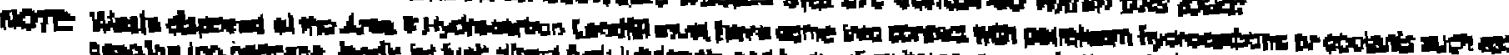

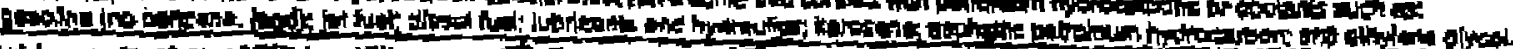

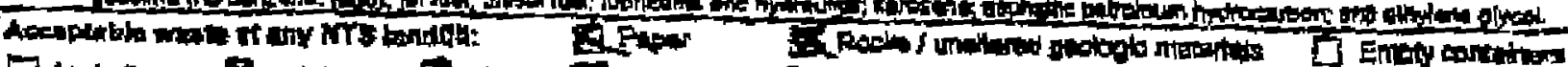

Grater

instint

4 hood bostow

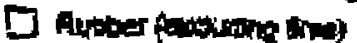

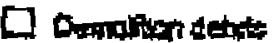

G Phase

Prinew D cleth

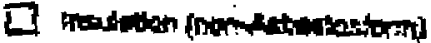

D Cenam ancion

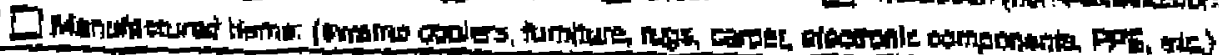

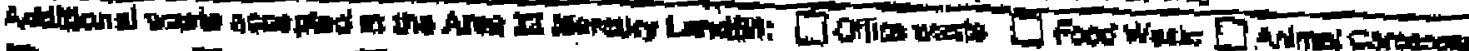

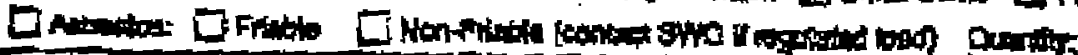

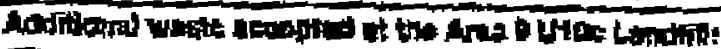

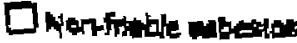

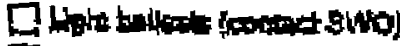

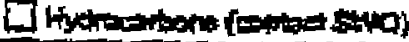

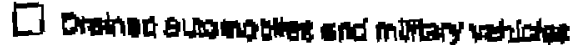

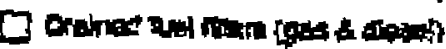

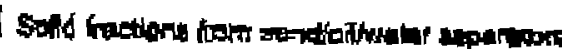

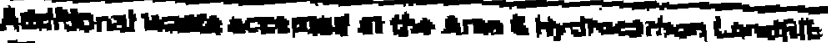

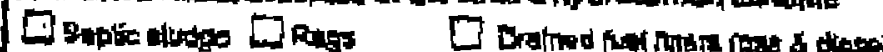

Dratit

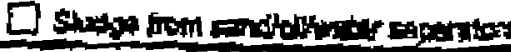

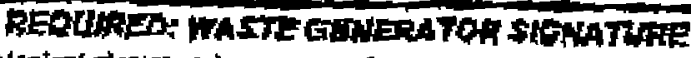

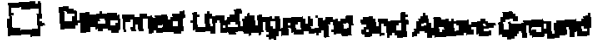
[I Thit:

Intation

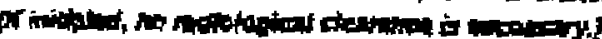

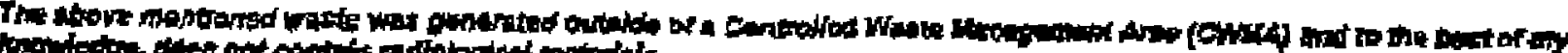

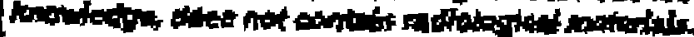

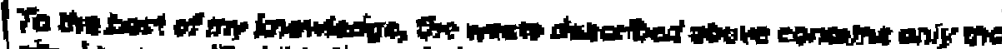

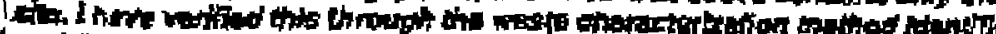

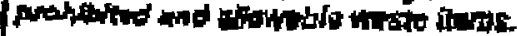

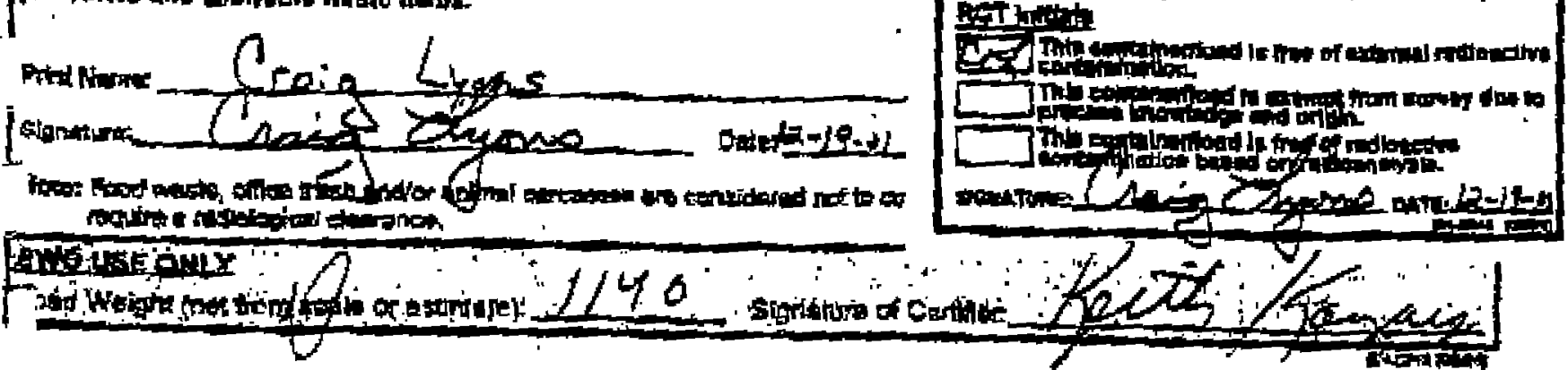




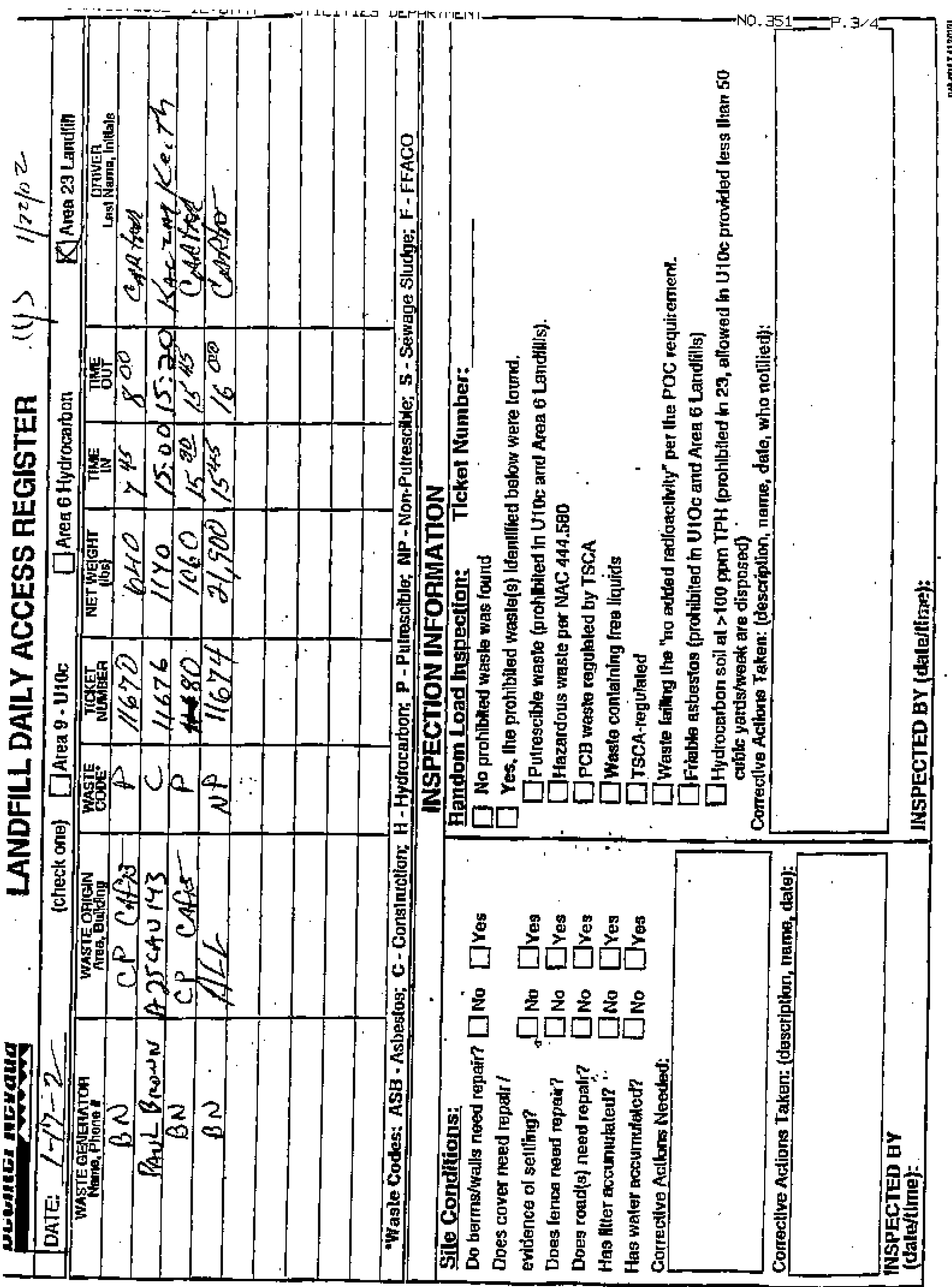

$E-7$ 


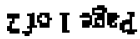

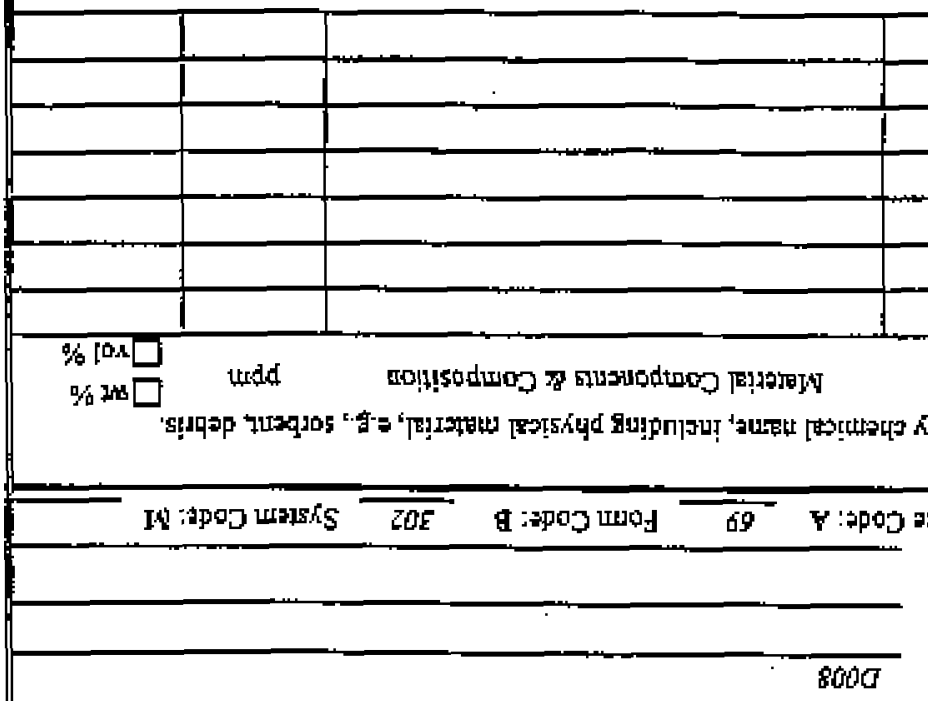

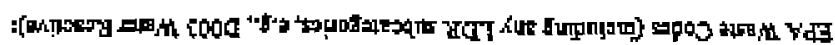

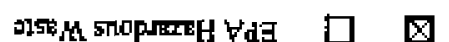

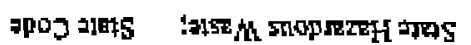

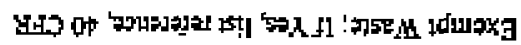
口

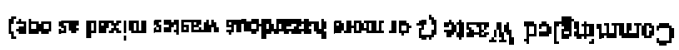

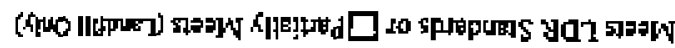

Q $\square$

$\square \square$ 口 田 $\square$ $\mathrm{Q} \square$

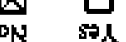

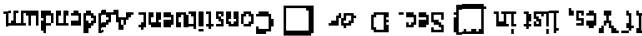

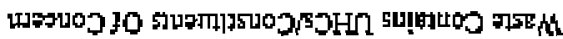

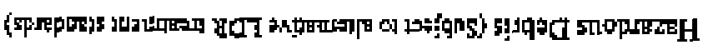

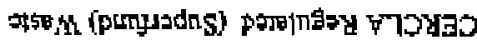

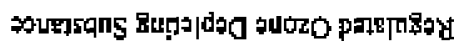

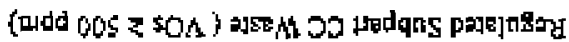

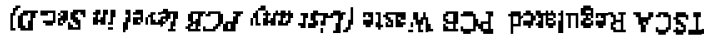

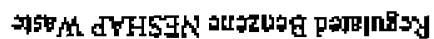

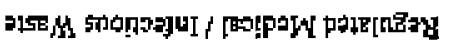
ज15e

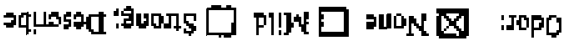

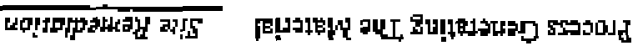

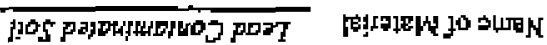

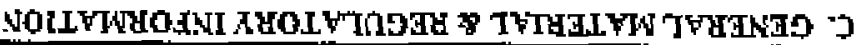

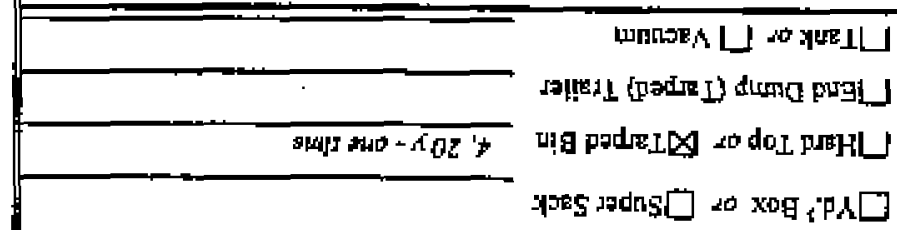

Sousnasy

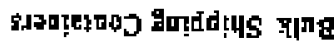

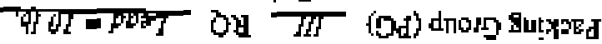

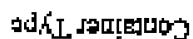

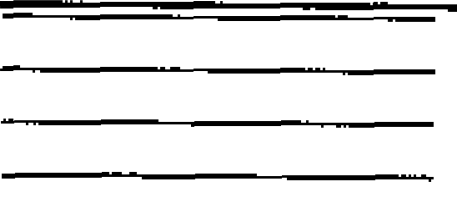

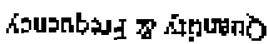
f

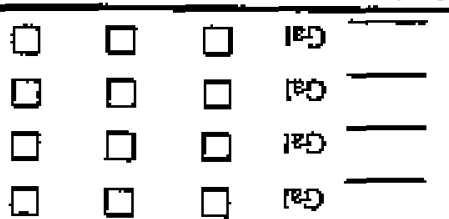

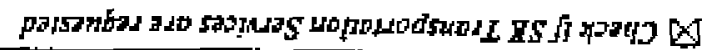

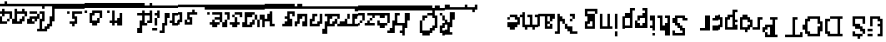

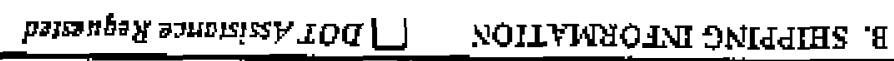

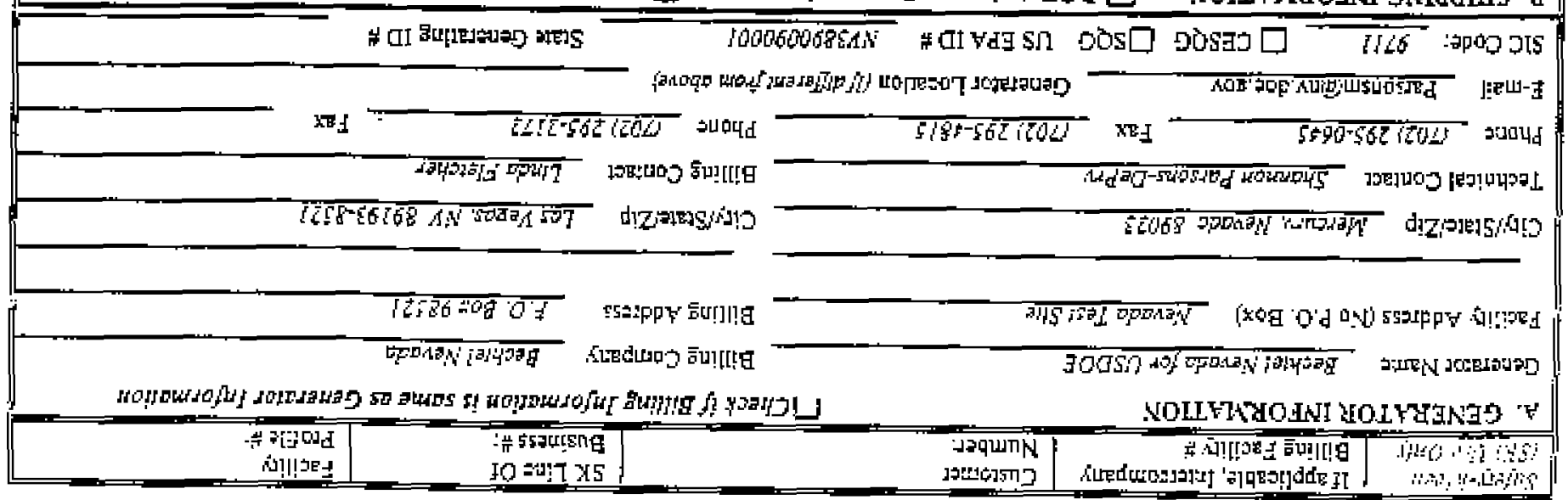

\section{TTIJO世 TFIA}


SafeTy-KLeEN MLterial Profile (continued):

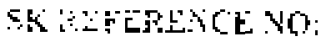

8031424

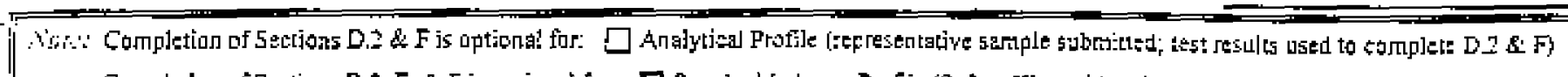

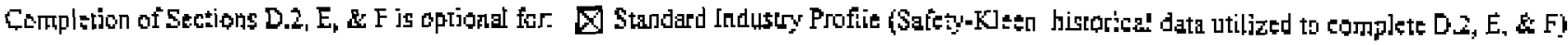

D. MLAERLAL COHPOSITION (Coninued)

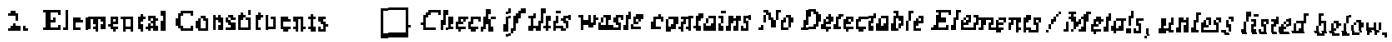

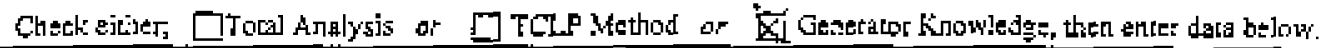

\begin{tabular}{|c|c|c|c|c|c|c|c|c|}
\hline Cansciptent & PF直 & Constinuexe & $\mathrm{Fprr}$ & Congtitued! & Eonstitu=n: & $\mathrm{Ppm}$ & Cone citutent & $\mathrm{FFm}$ \\
\hline 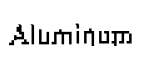 & & Cadsium & & Fluotine $/ 7 / 2 / 4$ & Niskel & & Sodium. & \\
\hline Astimony & & Chlorine & & Lea $30 \mathrm{~K}-200=2 \mathrm{~L}$ & Phosphorous & & Sப]tิז & \\
\hline Arsentie & & Chromium & & Lithium & Potessictom & & 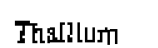 & \\
\hline Bariunn & & Cobalt & & Marganest & St] & & Titanjuts & \\
\hline Eeryllitum & & Copper & & Me्rсшу & Sïtleon & & Vanadjum & \\
\hline Bromin: & & iodina & & Molybdenum & & & Zine & \\
\hline
\end{tabular}

E. REACITV CHARACIERISTICS Q Chech of this waste exhibits ho Reachive Charagteristior

$Y=10$

$\square$ Explosive

$\square \quad$ Shoch Sensitive

$\mathrm{Ver} \mathrm{No} \quad$ Yes No

$\square \square$ Pyopharic

$\square \square \quad$ Oxidizer

$\square \square$ Reacti $\square$ Cyanide

gpm

$\square \square \quad$ Air Reactive

Reactive Sulfide

Poly'merizable

Other Insowidgatibles: Describe

F. MATERLAL PHYSICAL CHARACTERISTICS 0 70 ${ }^{\circ} \mathrm{F}$.

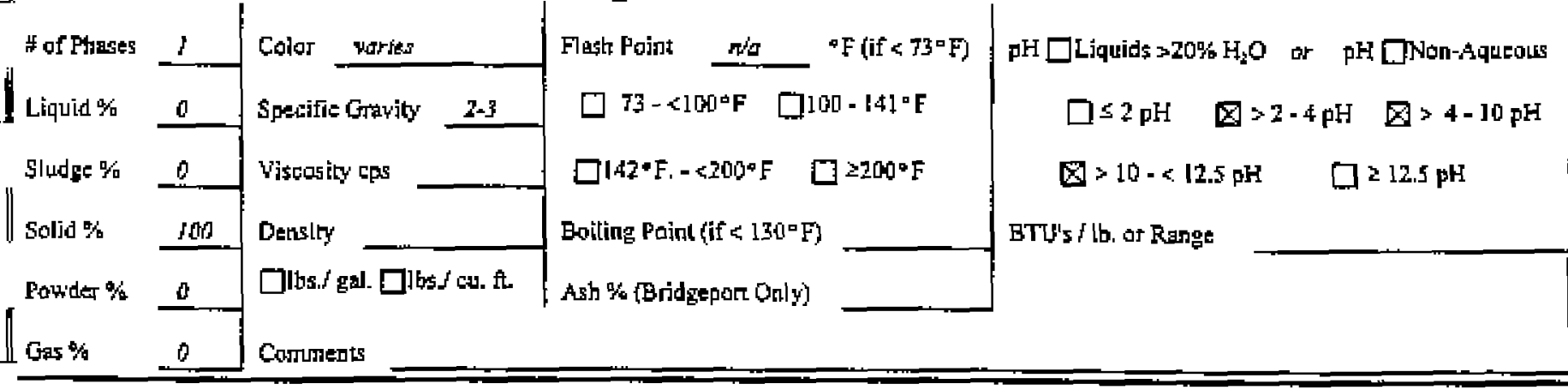

G. GENERATOR PROFILE CERTIFICATION

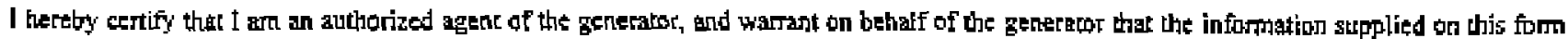
and on any attangmens or supplements hereto is complete and aseurace, and that all known or suspected hazards of the material(s) described

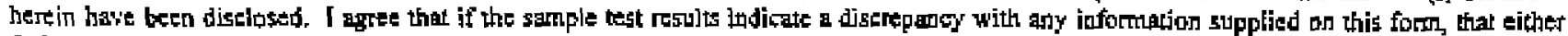

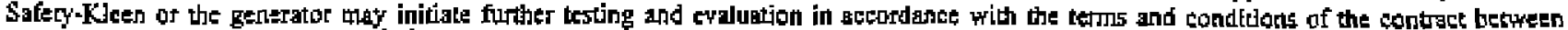

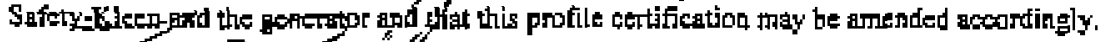

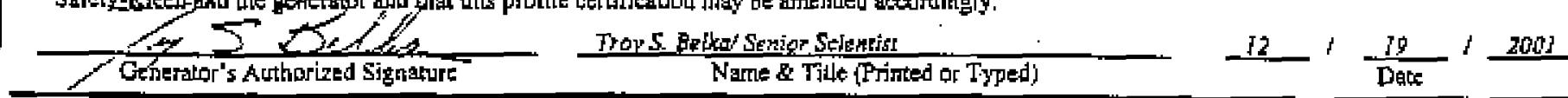

Comments

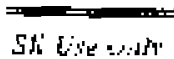

SK Sales Rep. Name

PTOEess Approval \#

Warte Appropal af Cerffication

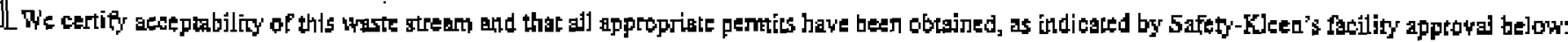

П SKos $П$ sKVS ПNon-haz Evaluation П Standard Industy Pofile: SI Index \# Emplaye H

Product Code or Part $\frac{\text { N }}{\text { n }}$

Niante e Title (Printed or Typed)

Det:

Page 2 of 2
Territory/Branch \#

Pricing 


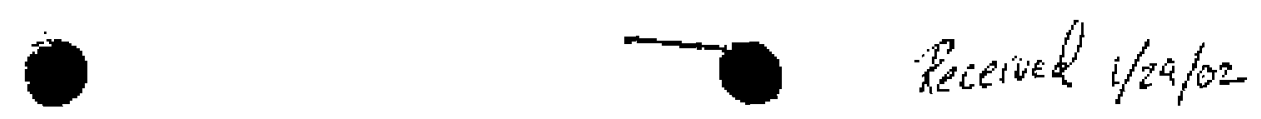

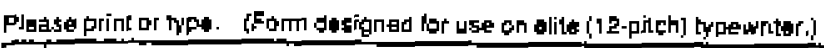

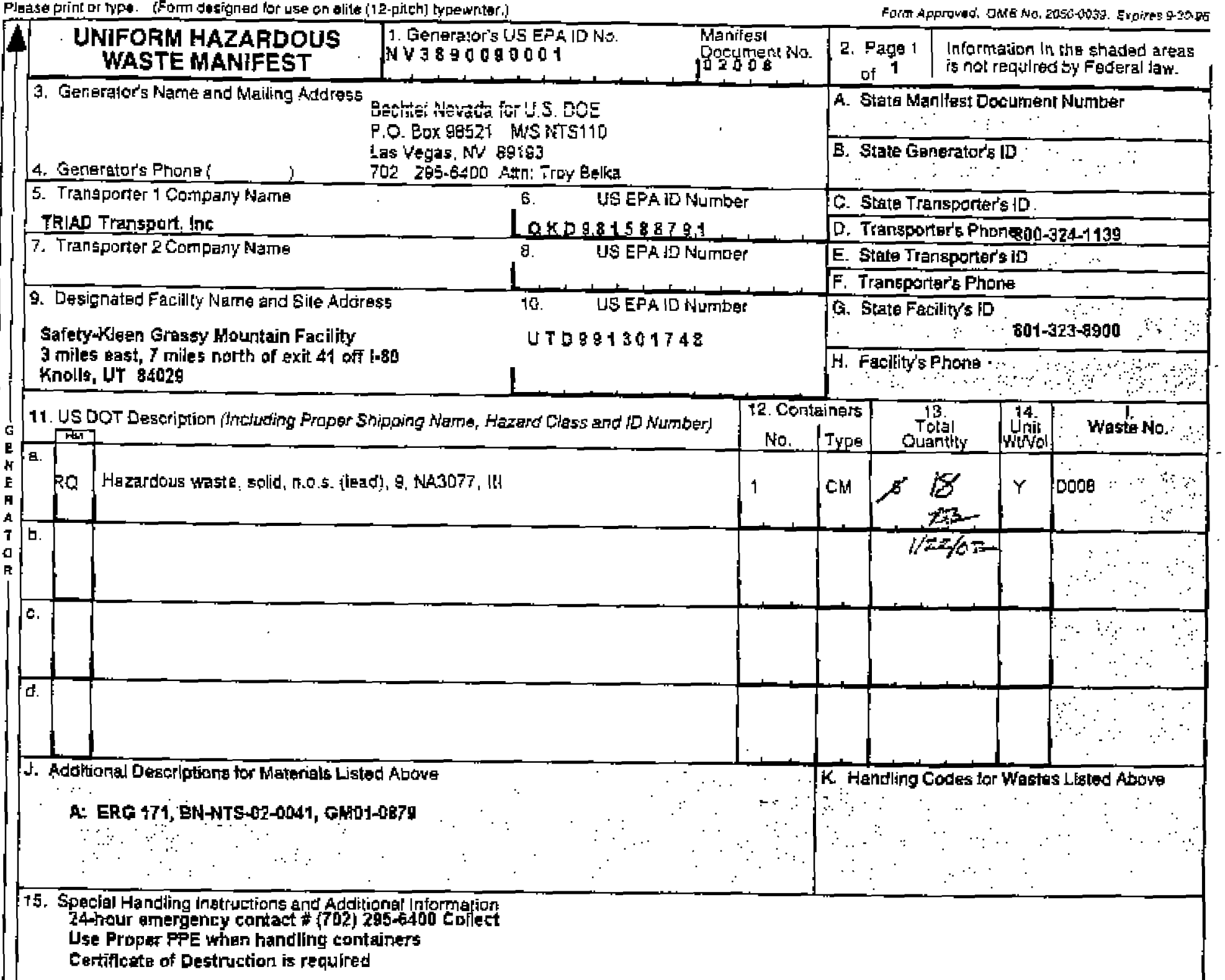

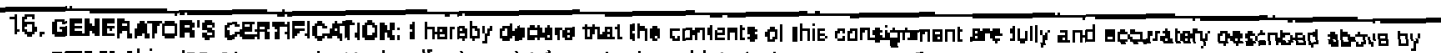

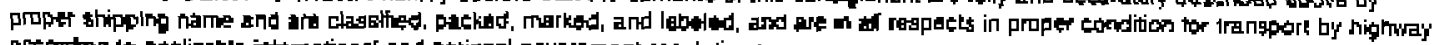

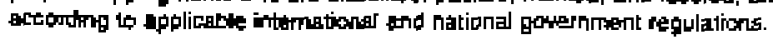

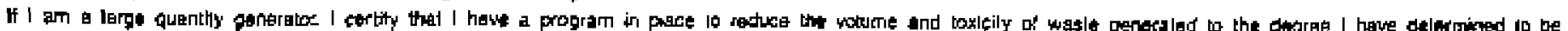

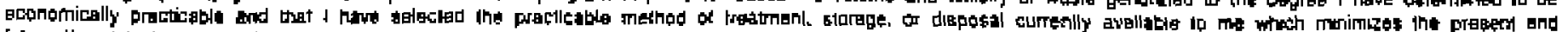

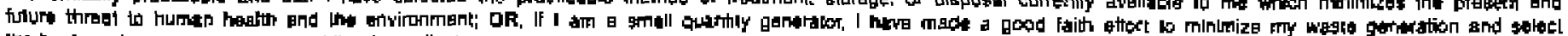

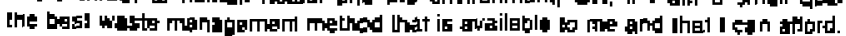

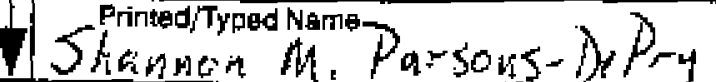

17. Transporter 1 Acknowiedgement of Receipt of Materiats

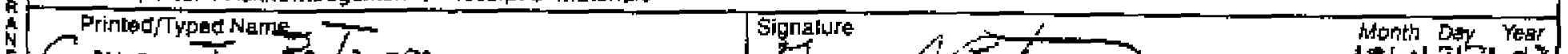

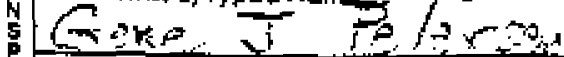

9 19. Frameporter 2 Acknowtedgement of Boceipt of Materials

Prinked,Typed Name

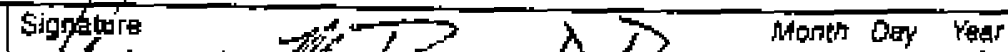

19. Discrepaney indication Spece

F

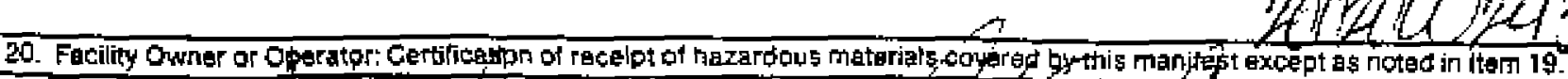

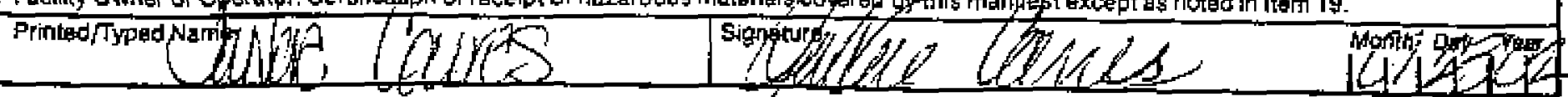

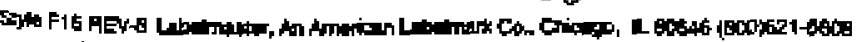




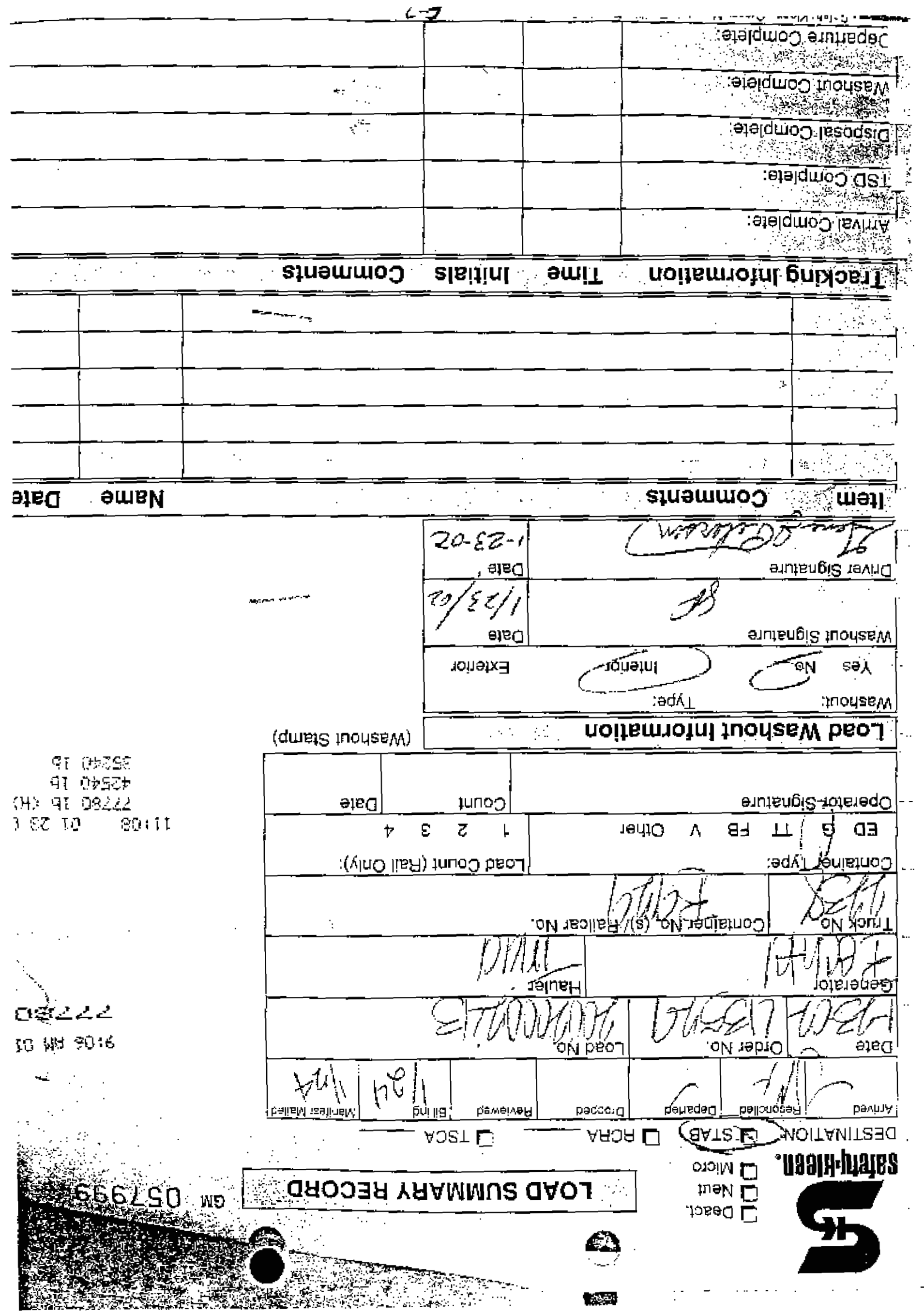




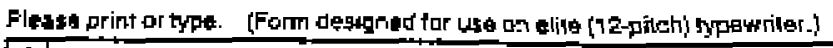

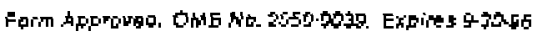

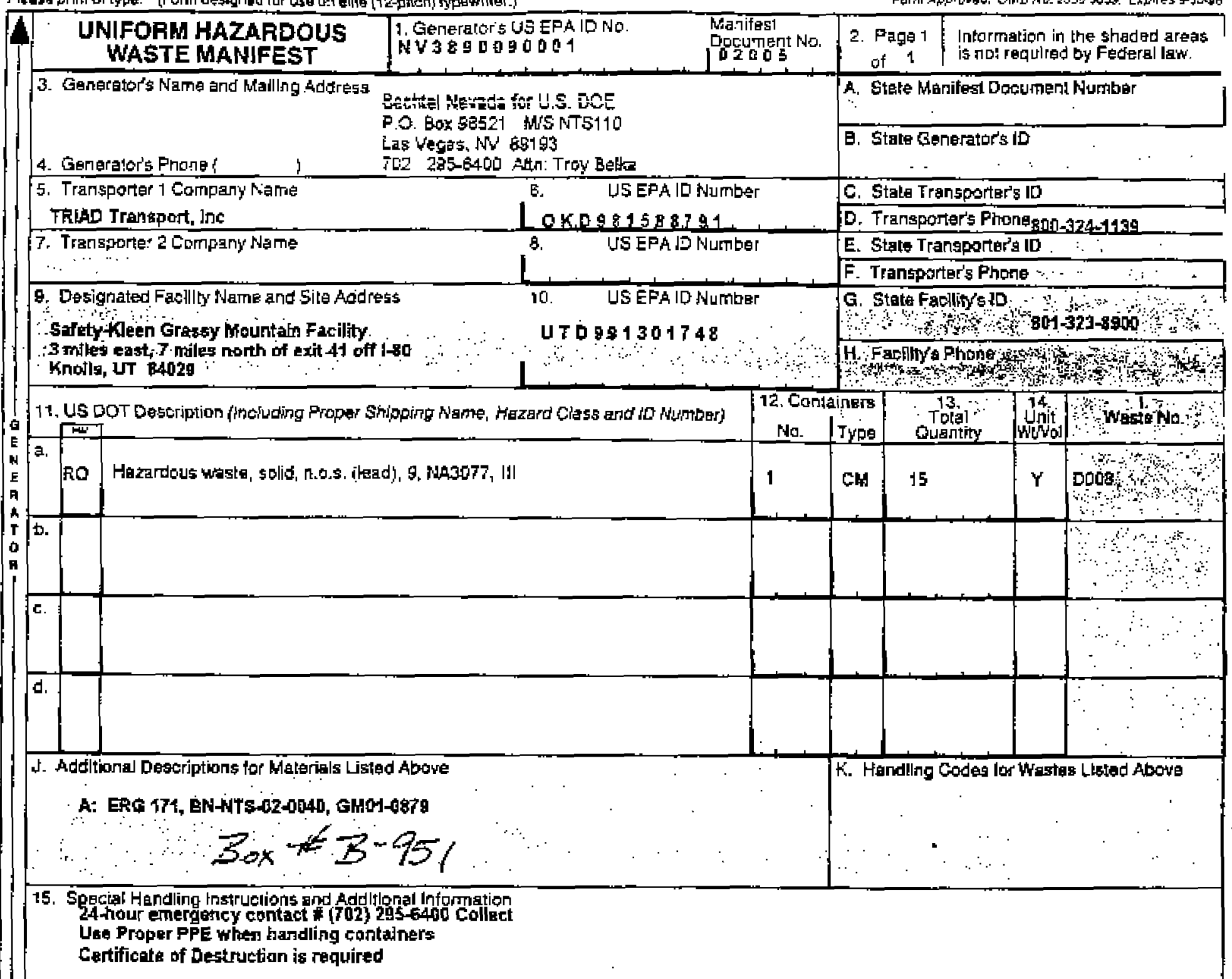

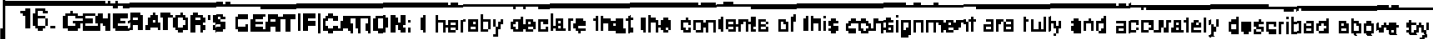

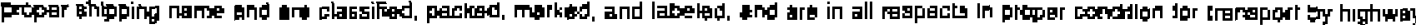

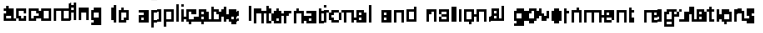

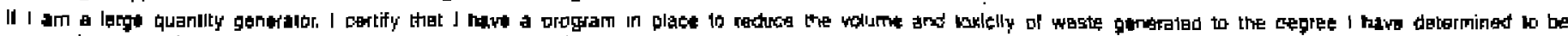

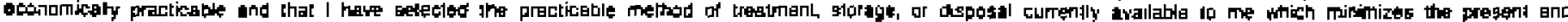

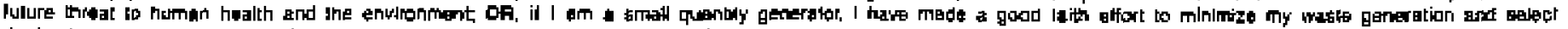

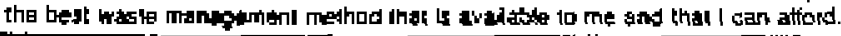

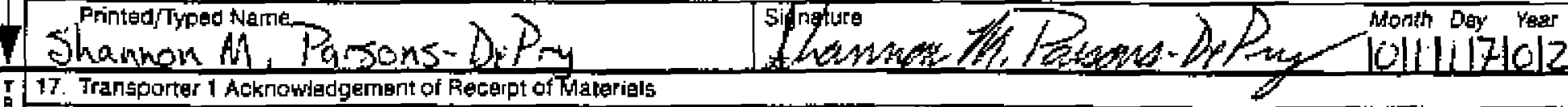

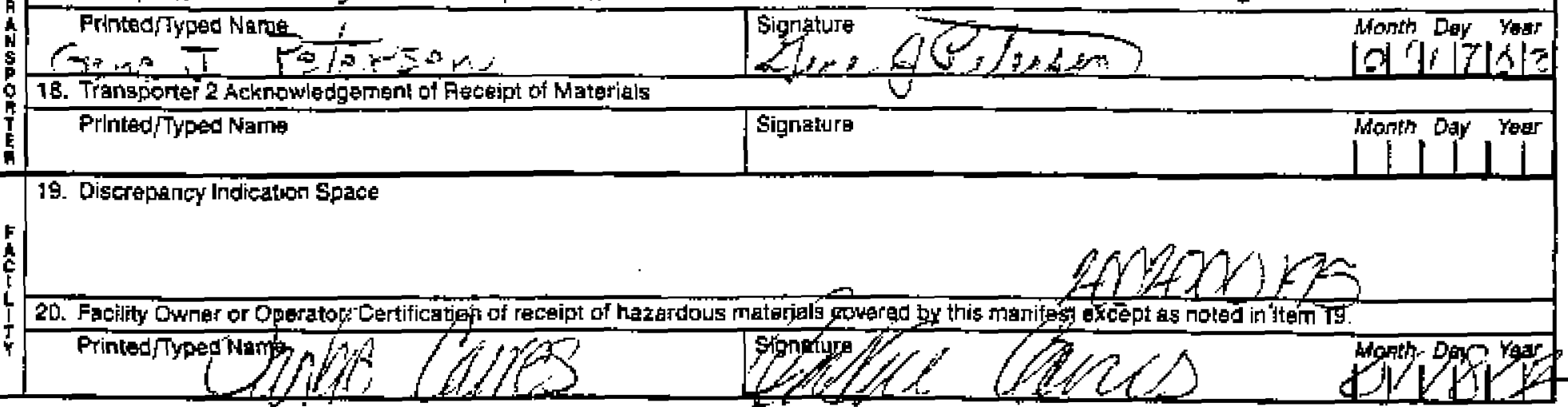

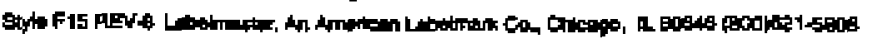

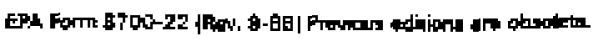




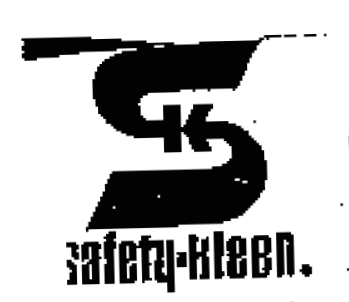

DESTINATION: QSTAB

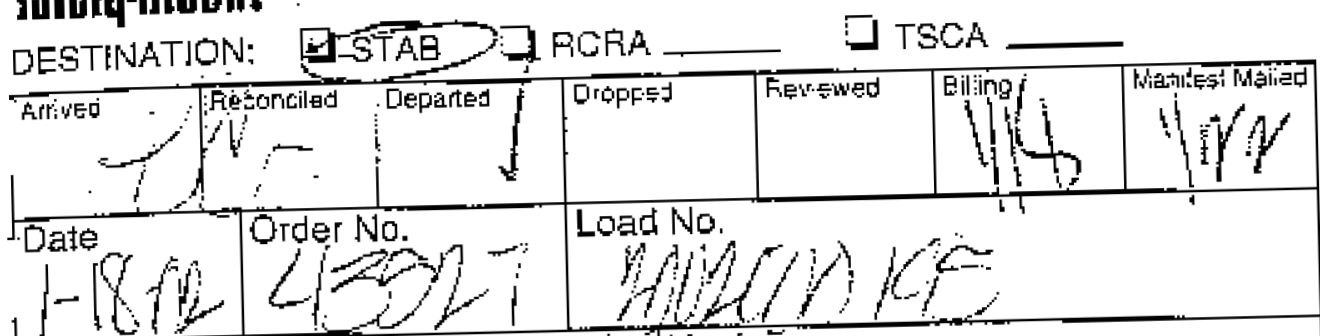

Date $=0$ order No.

Generator
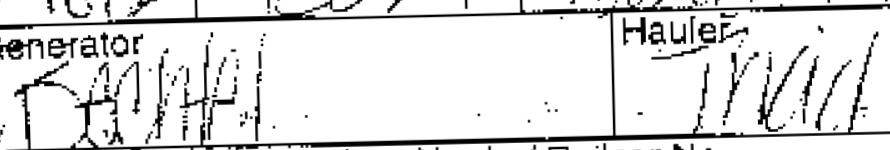

Trak Noy Container No (s)/ Railcar No.

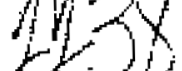

Containet Type:

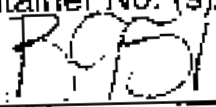

$\mathrm{ED} / \mathrm{G} T \mathrm{~F}$ FB $V$ other

$\sqrt{1 / 1} / 1$

$7 \times 241$

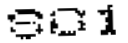

Operatö Signature

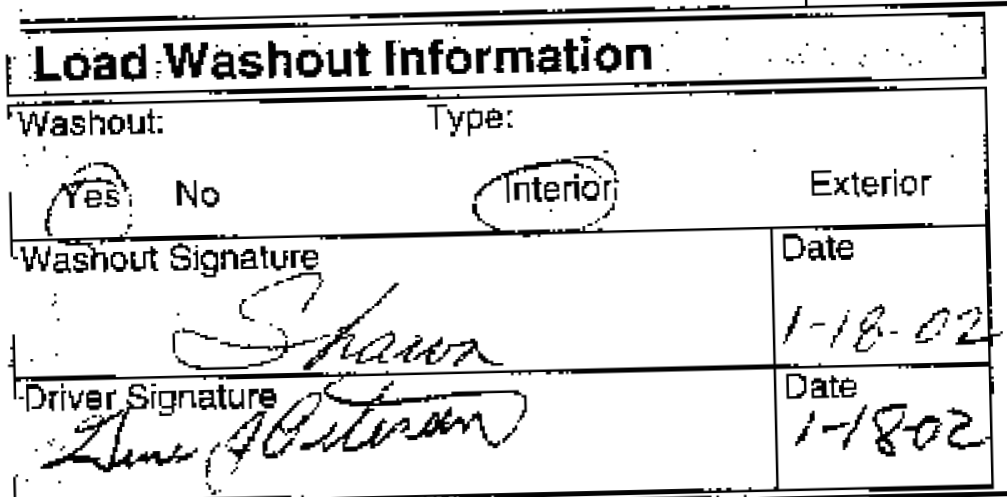

(Washout Stamp)

of 30 Di

50189 ib

42420 in

376015

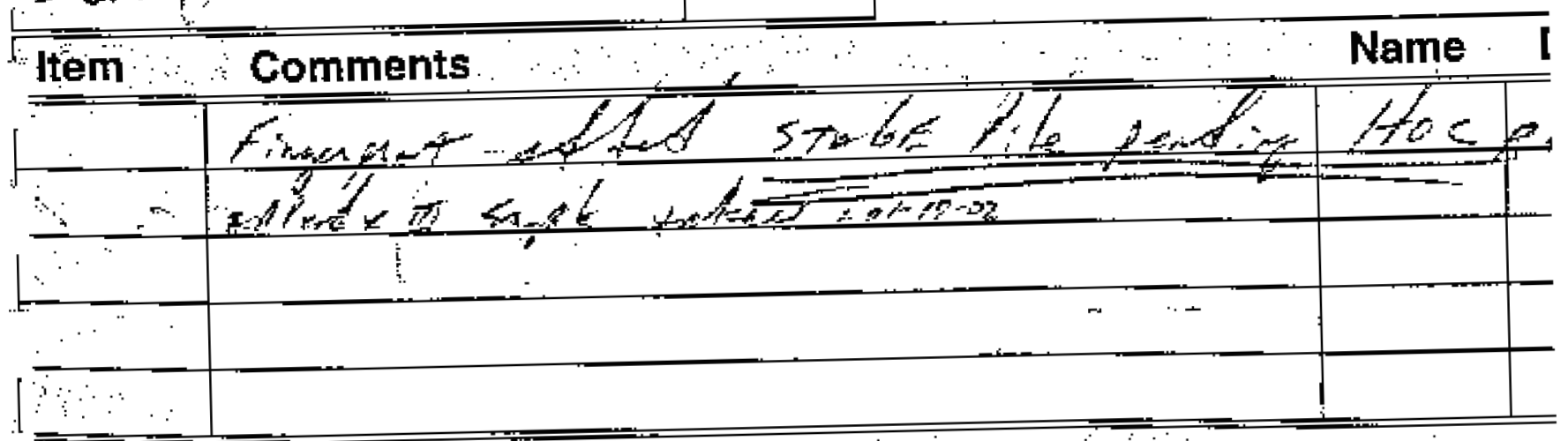

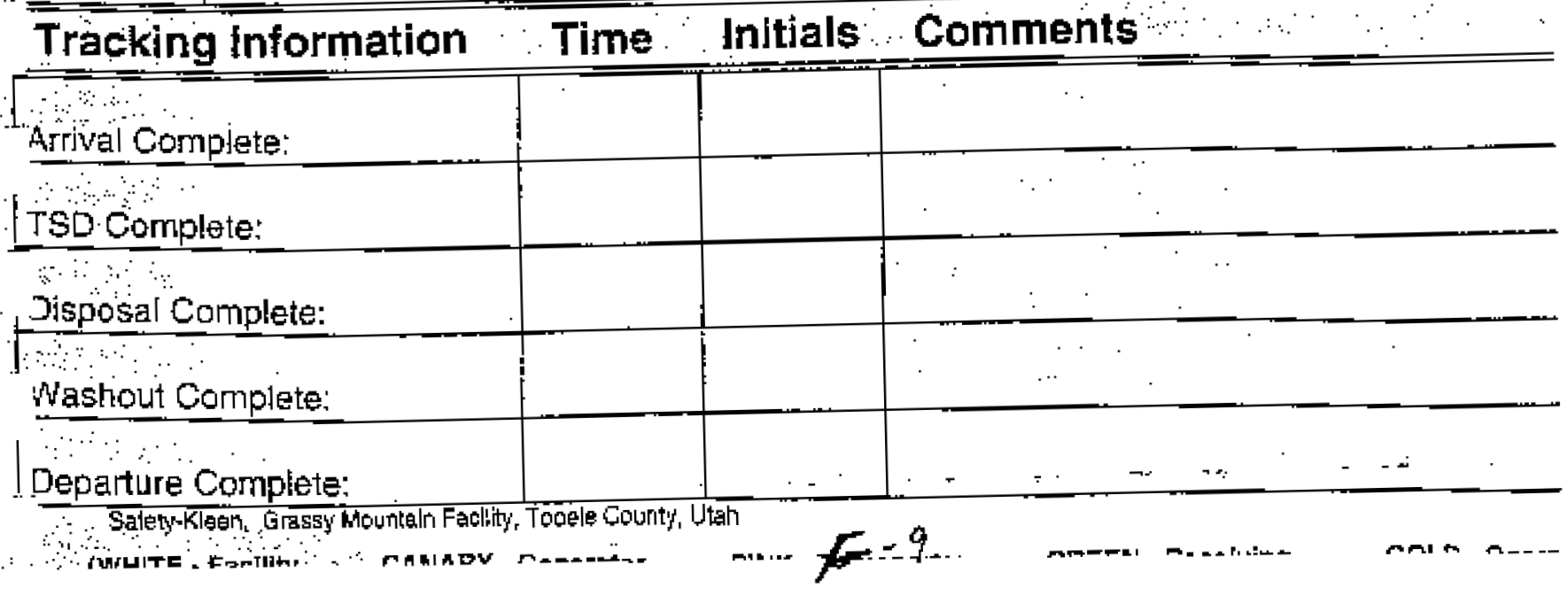




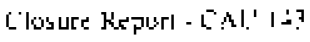

Secion Aplendaci

Retision: 0

[and Minci 200

\section{APPENDIX G}

\section{FIELD PHOTOGRAPHS}




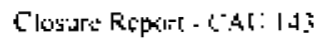

bes climi Appetidx of

Rewisun: 6

Dare: March tour

THIS PAGE TNTENTIONALLY LEFT BLANK 


\section{CAU 143 FIELD PHOTOGRAPH LOG}

\begin{tabular}{|c|l|l||}
\hline $\begin{array}{c}\text { PHOTO } \\
\text { NLMBER }\end{array}$ & DATE & \multicolumn{1}{|c|}{ DESCRIPTION } \\
\hline \hline 1 & $09 / 18 / 2001$ & $\begin{array}{l}\text { R-MAD East Trestle Area before demolition and backfilling } \\
\text { activities. }\end{array}$ \\
\hline 2 & $12 / 05 / 2001$ & $\begin{array}{l}\text { R-MAD East Trestle Area after demolition and backfilling } \\
\text { aclivities. }\end{array}$ \\
\hline 3 & $09 / 18 / 2001$ & R-MAD West Trench Berms before remediation. \\
\hline 4 & $01 / 24 / 2002$ & R-MAD West Trench Berms alter remediation. \\
\hline 5 & $12 / 05 / 2001$ & $\begin{array}{l}\text { Metal debris discovered in the West Trench Berm area during } \\
\text { remediation. }\end{array}$ \\
\hline 6 & $12 / 05 / 2001$ & Subbasin 4 before erosion protection instatlation. \\
\hline 7 & $01 / 10 / 2002$ & Subbasin 4 placement of sand over geotextile naterial. \\
\hline 8 & $01 / 10 / 2002$ & Subbasin 4 placement of rip rap rock material. \\
\hline 9 & $01 / 10 / 2002$ & Rip rap rock placement in erosion channel area. \\
\hline 10 & $01 / 24 / 2002$ & Completion of erosion protection for Subbasin 4 \\
\hline 11 & $12 / 05 / 2001$ & Strontium-90 (Sr-90) impacted soil excavation area \\
\hline 12 & $12 / 05 / 2001$ & Container storage area for Sr-90 impacted soil \\
\hline 13 & $01 / 24 / 2002$ & Completion of erosion protection for Subbasin 5 \\
\hline 14 & $01 / 24 / 2002$ & Demobilization of the site and equipment \\
\hline
\end{tabular}


THIS PAGE DNTENTIONALLY LEFT BLANK

$0-2$ 


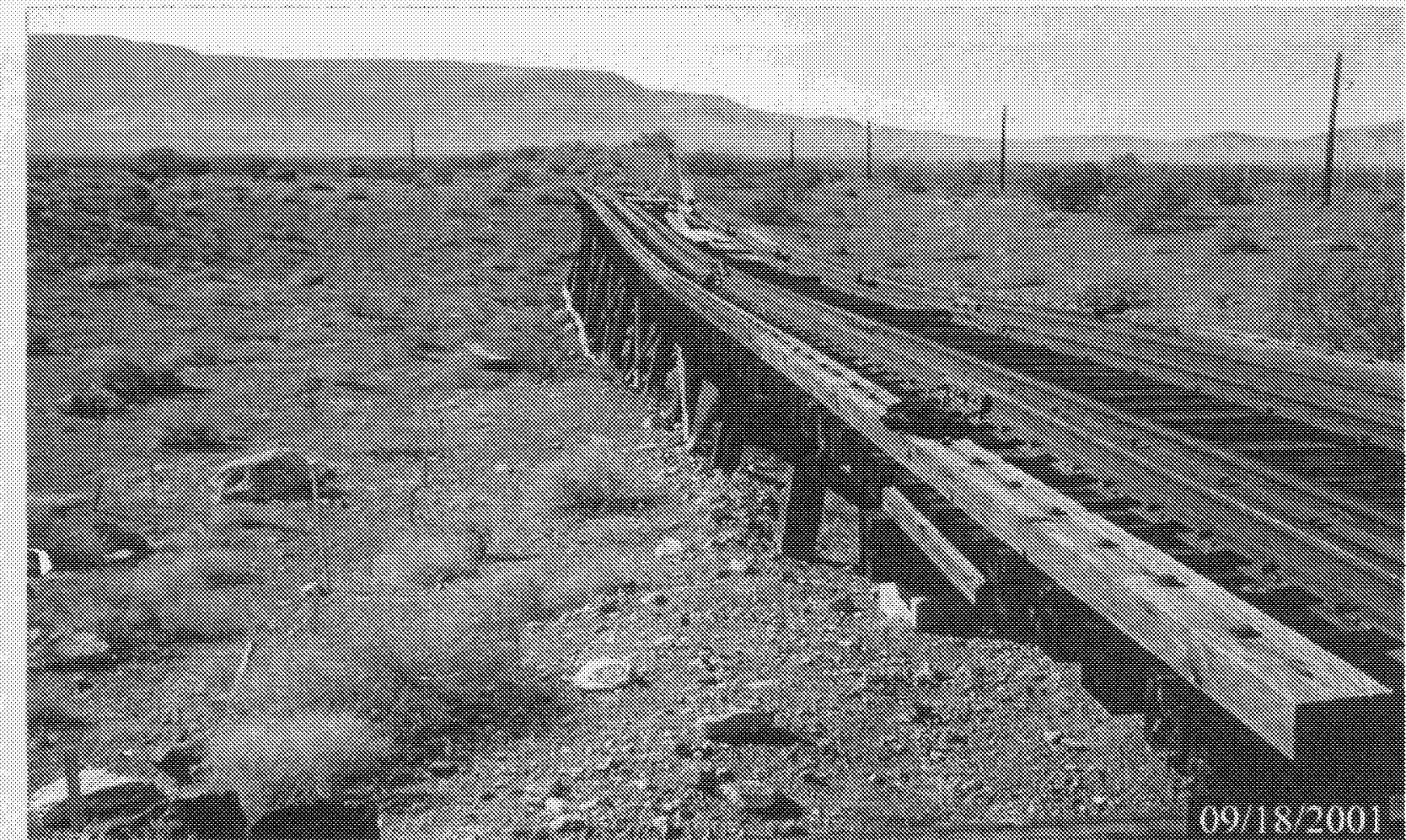

PUDOTOORAPH I - RMAD EAST TRESTIE AREA BEFORE DEMOIITION

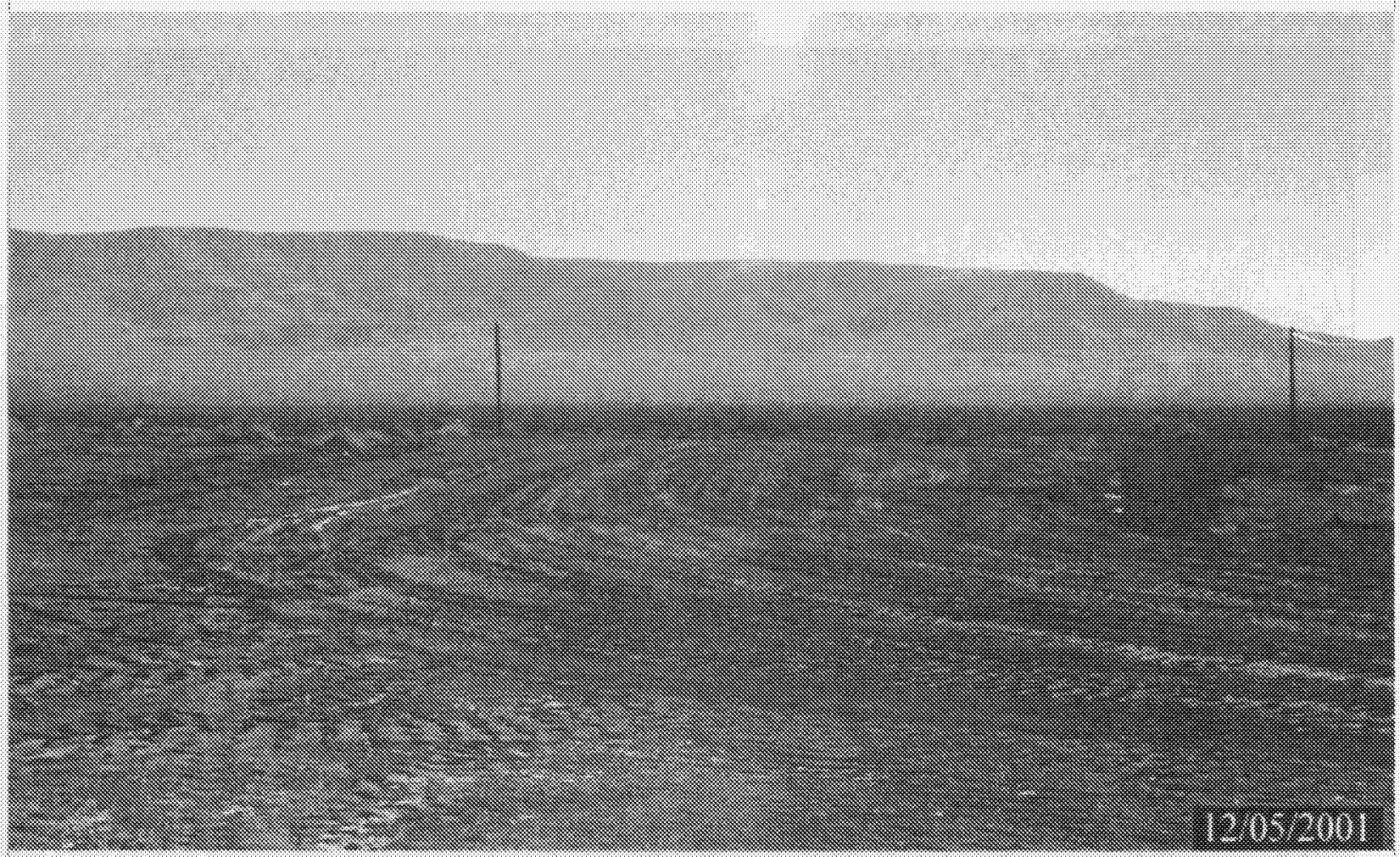

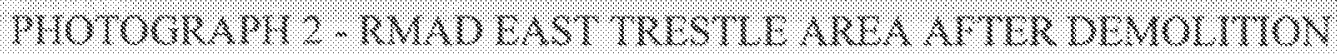




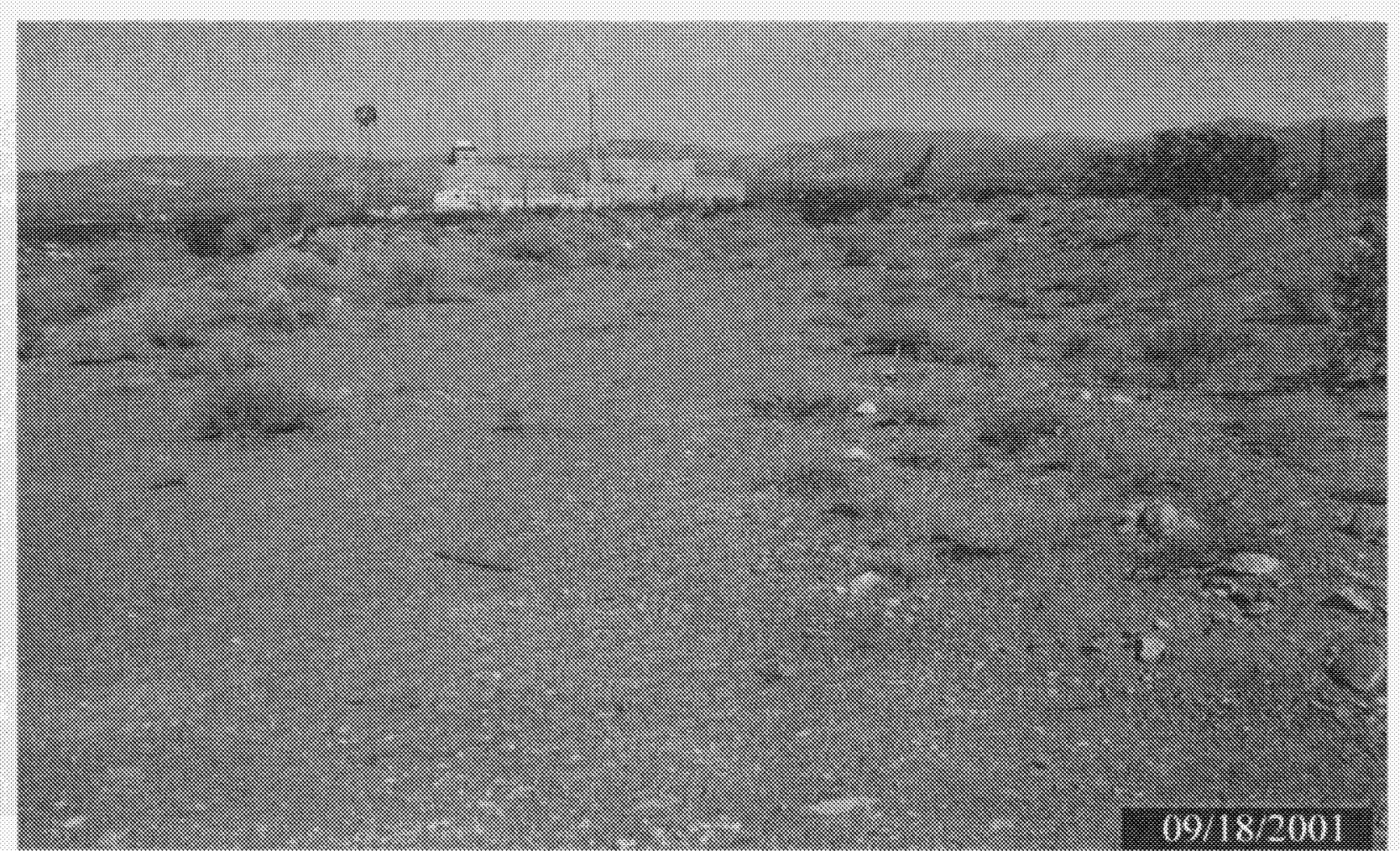

PHOTOORAFH 3 - RMAD WEST TRENCH RERMS BEFORE REMEDIATONN

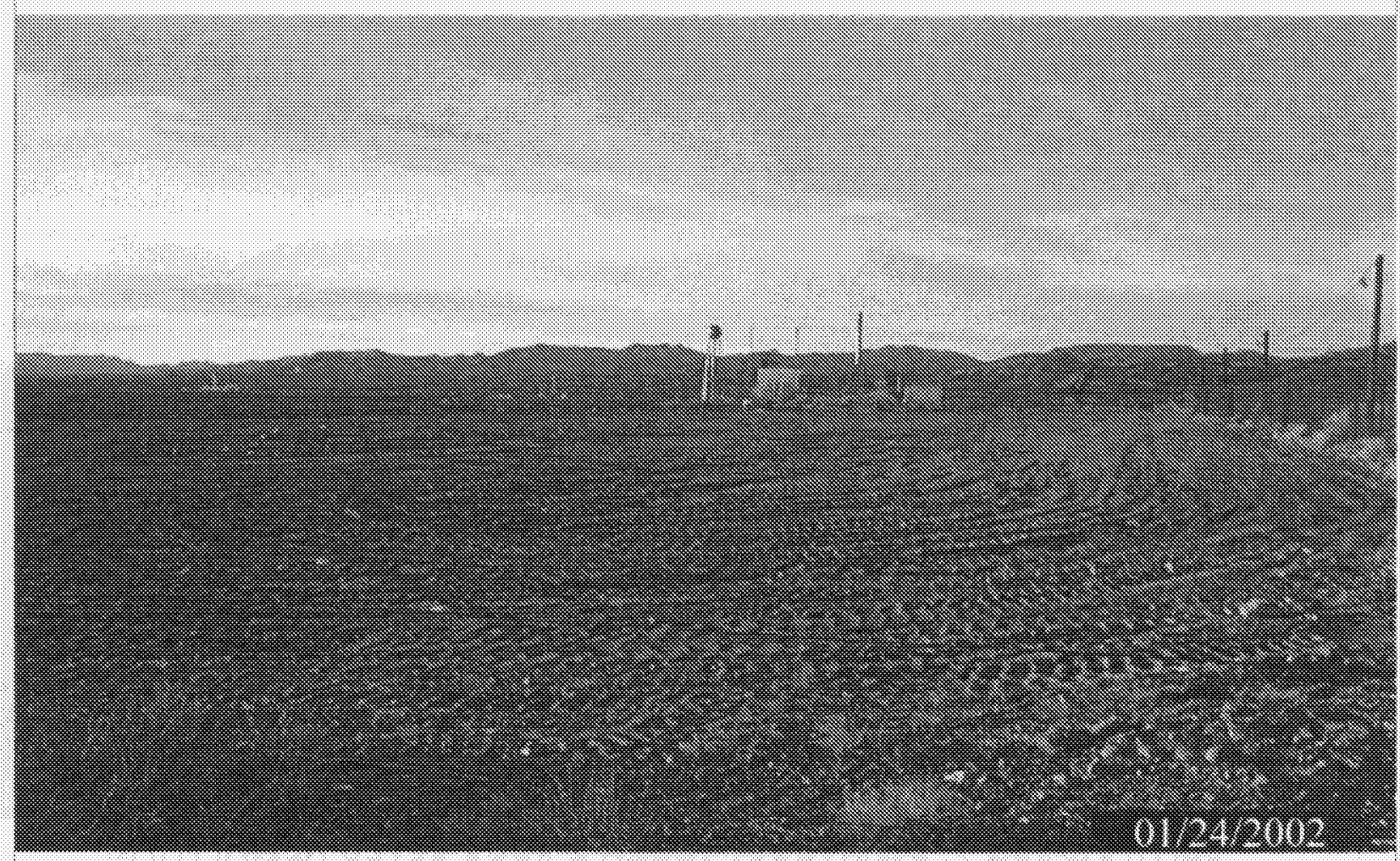

WHOTOORAPY 4 - RMAD WEST TRENCH BERMS AFTER REMEDWATION 


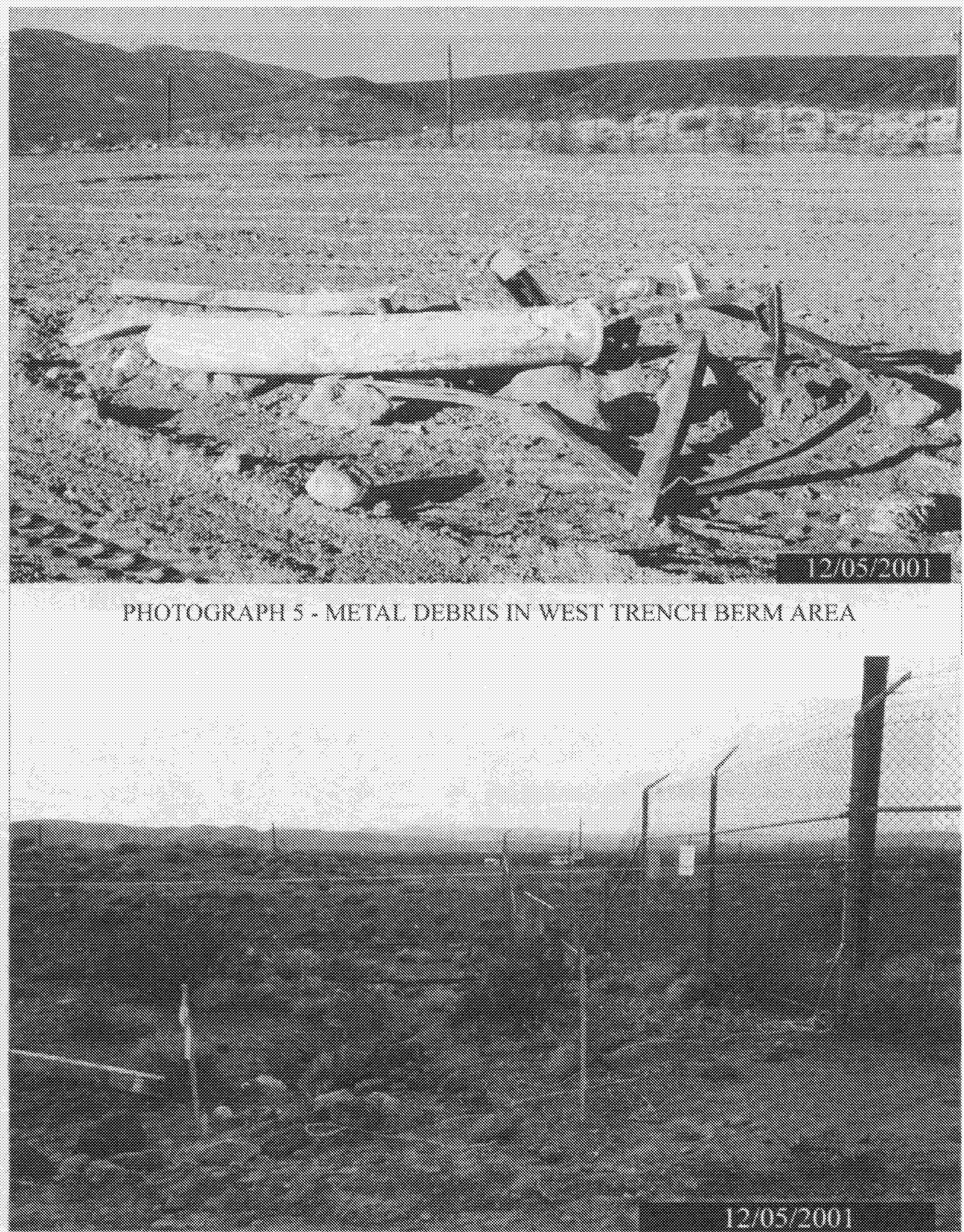

PHOTOGRAPU 6 - SUBBASIN 4 BEFORE EROSION PROTECTION NSTALLATION 


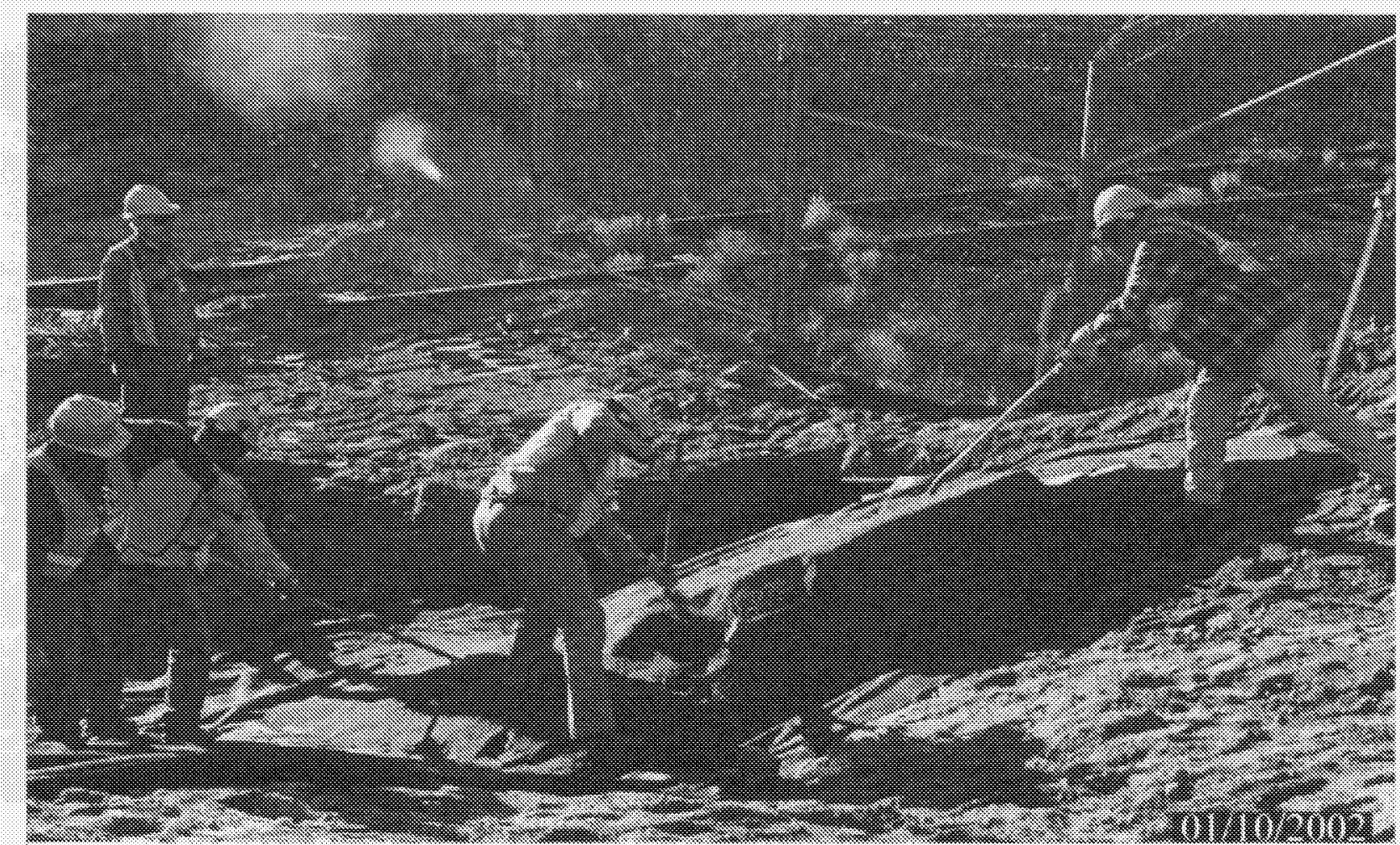

PHOTOORAPU ? - SUBBASIN 4 PY ACEMENT OF SAND OVER CYOCTEXTILE MATPRIAL

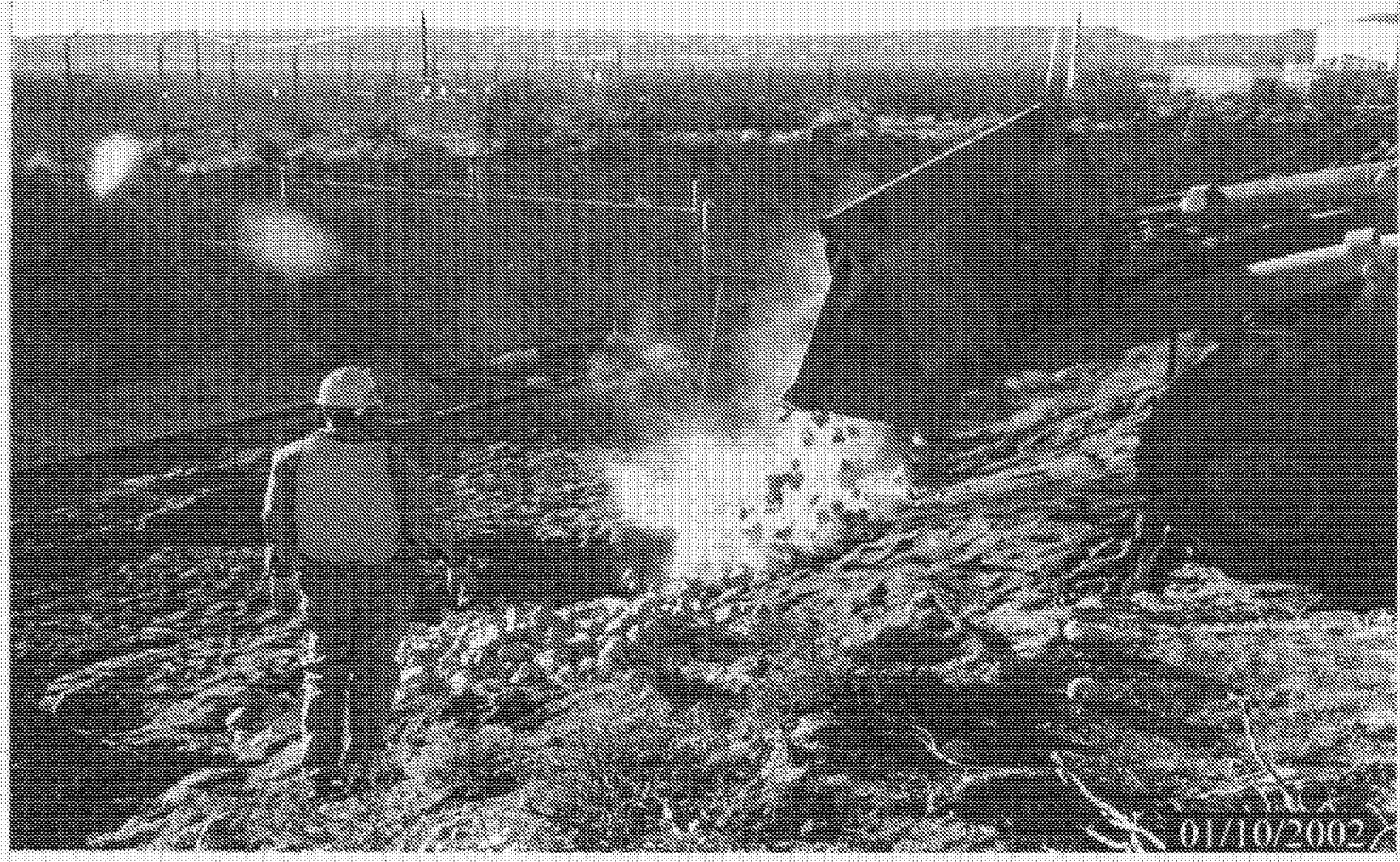

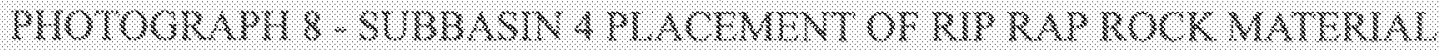




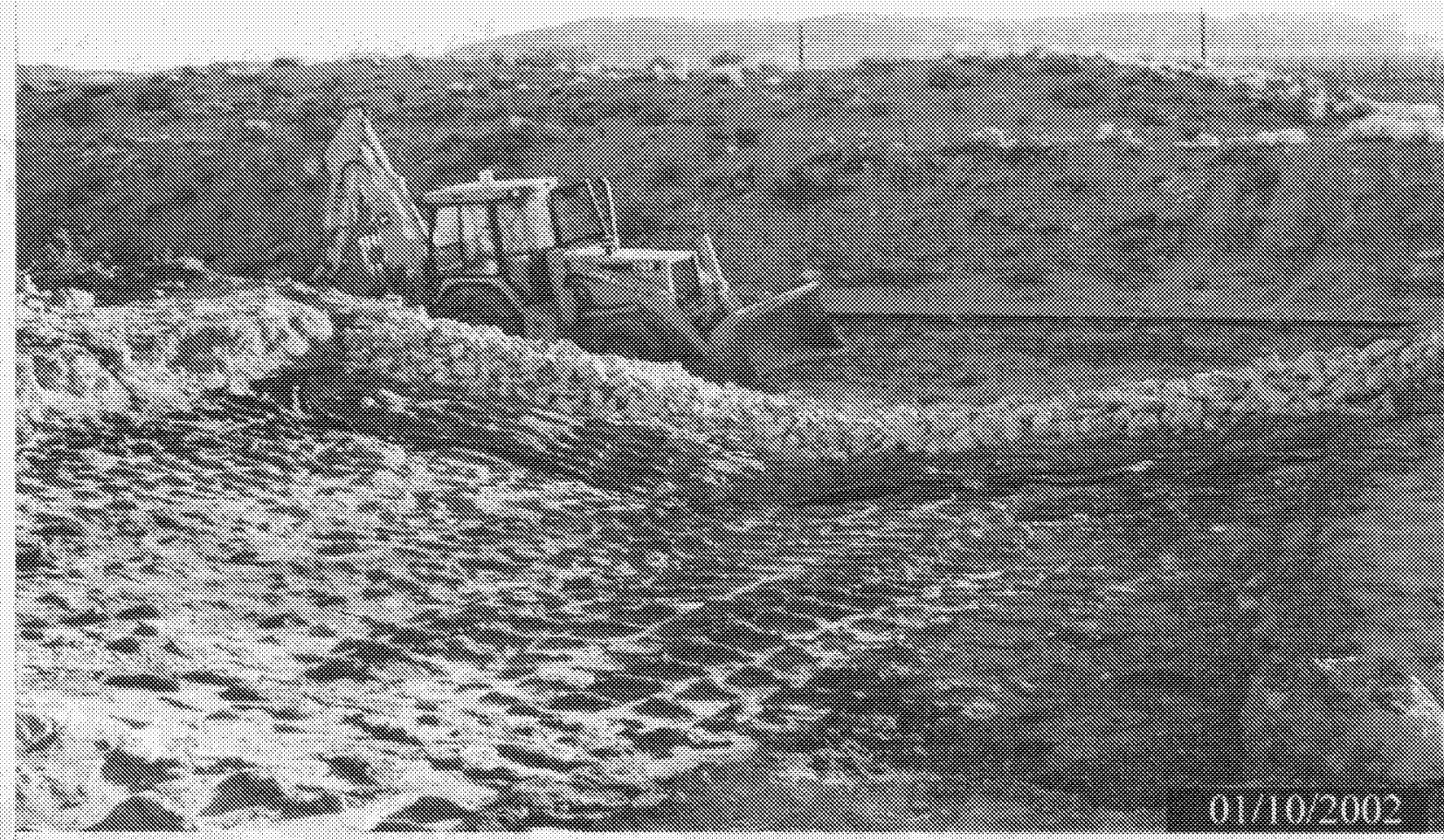

PHOTOORAPH 9 - RIP RAP ROCK PLACEMENT IN EROSION CHANNEL AREA

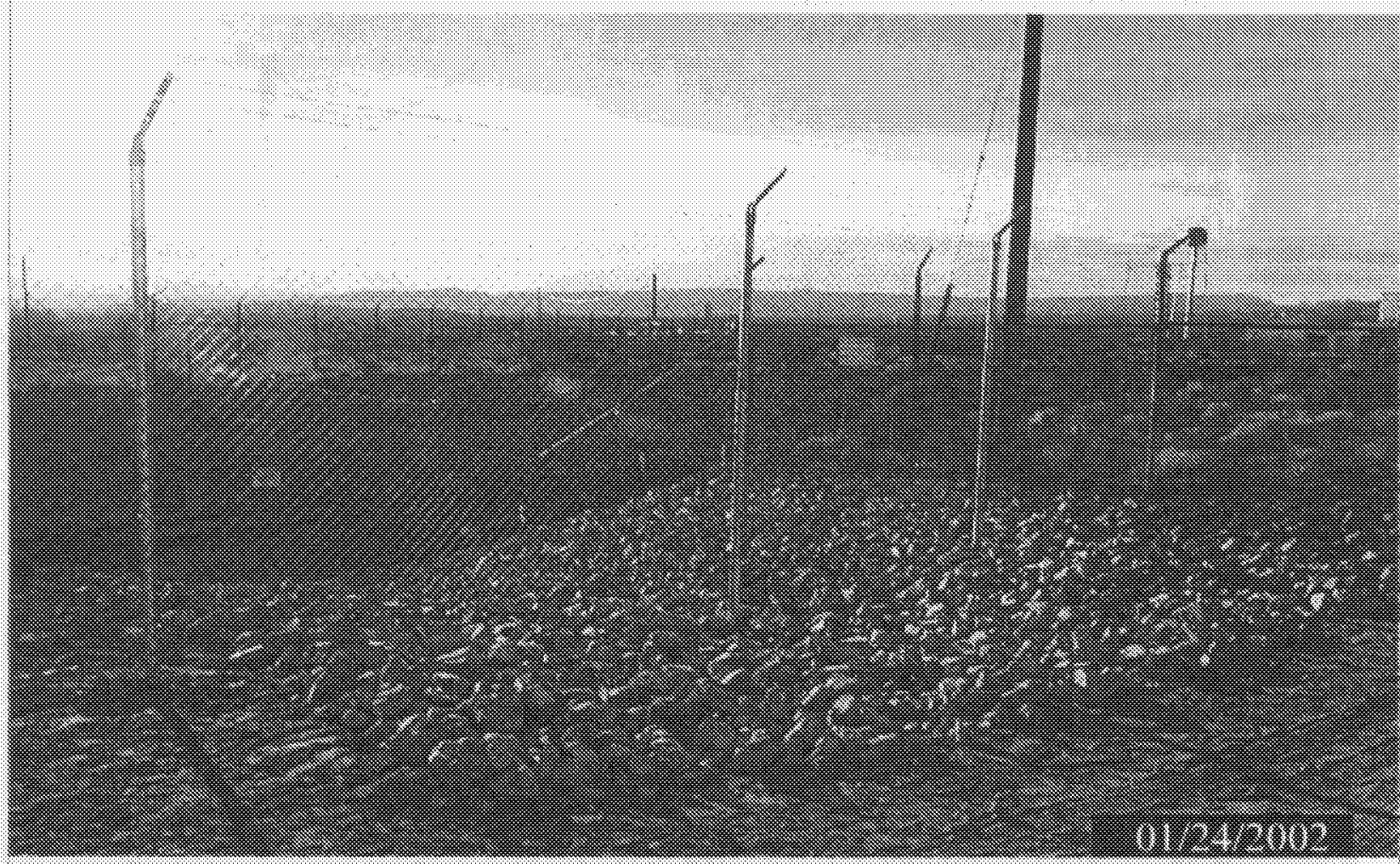

PHOTOORAPH 10 - COMPLETION OF EROSION PROTECTION FOR SUBBASIN 4 


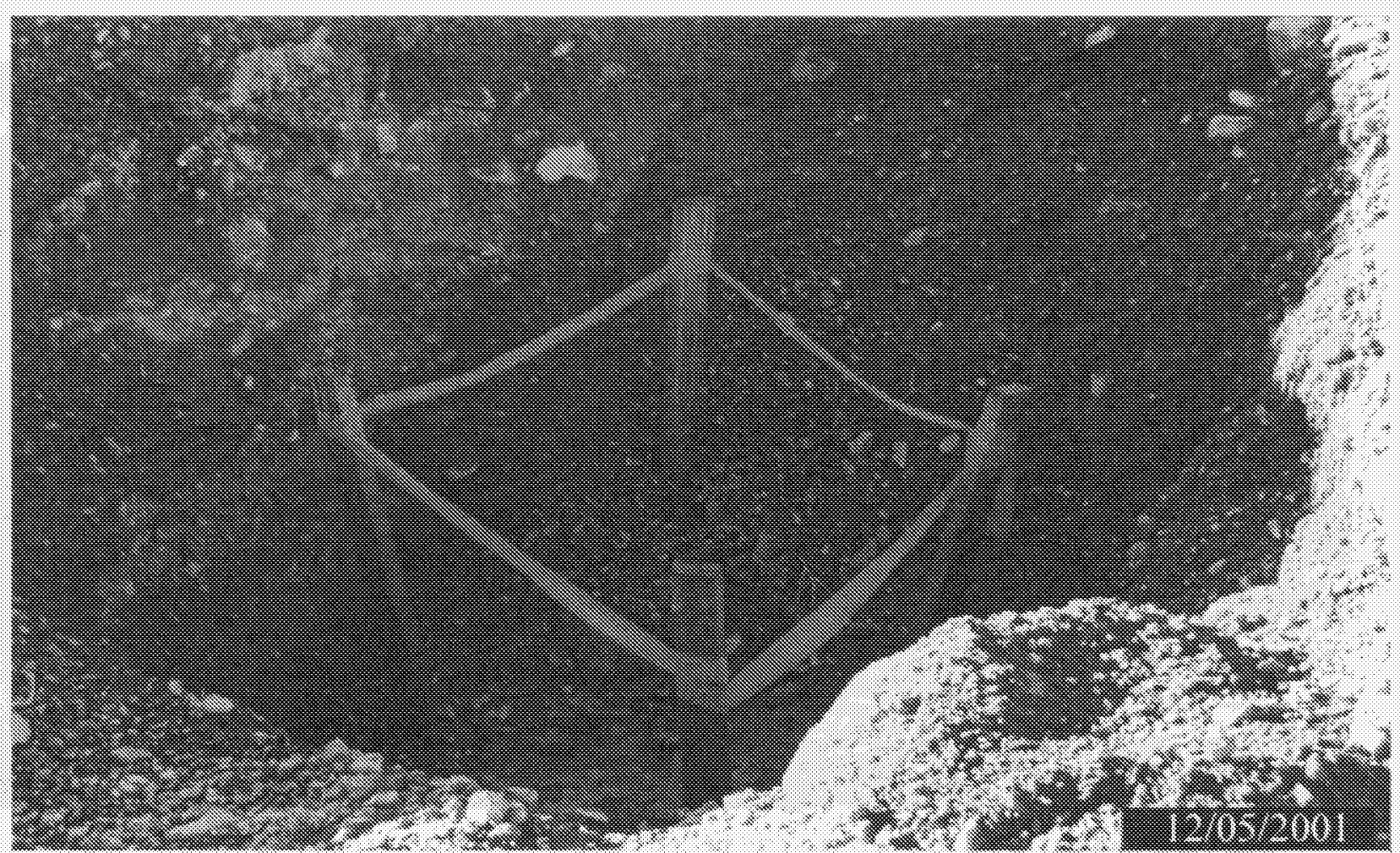

PYOTOCRAPH II * STRONTIUM -90 (SF-90) IMPACTED SOL EXCAVATION AREA

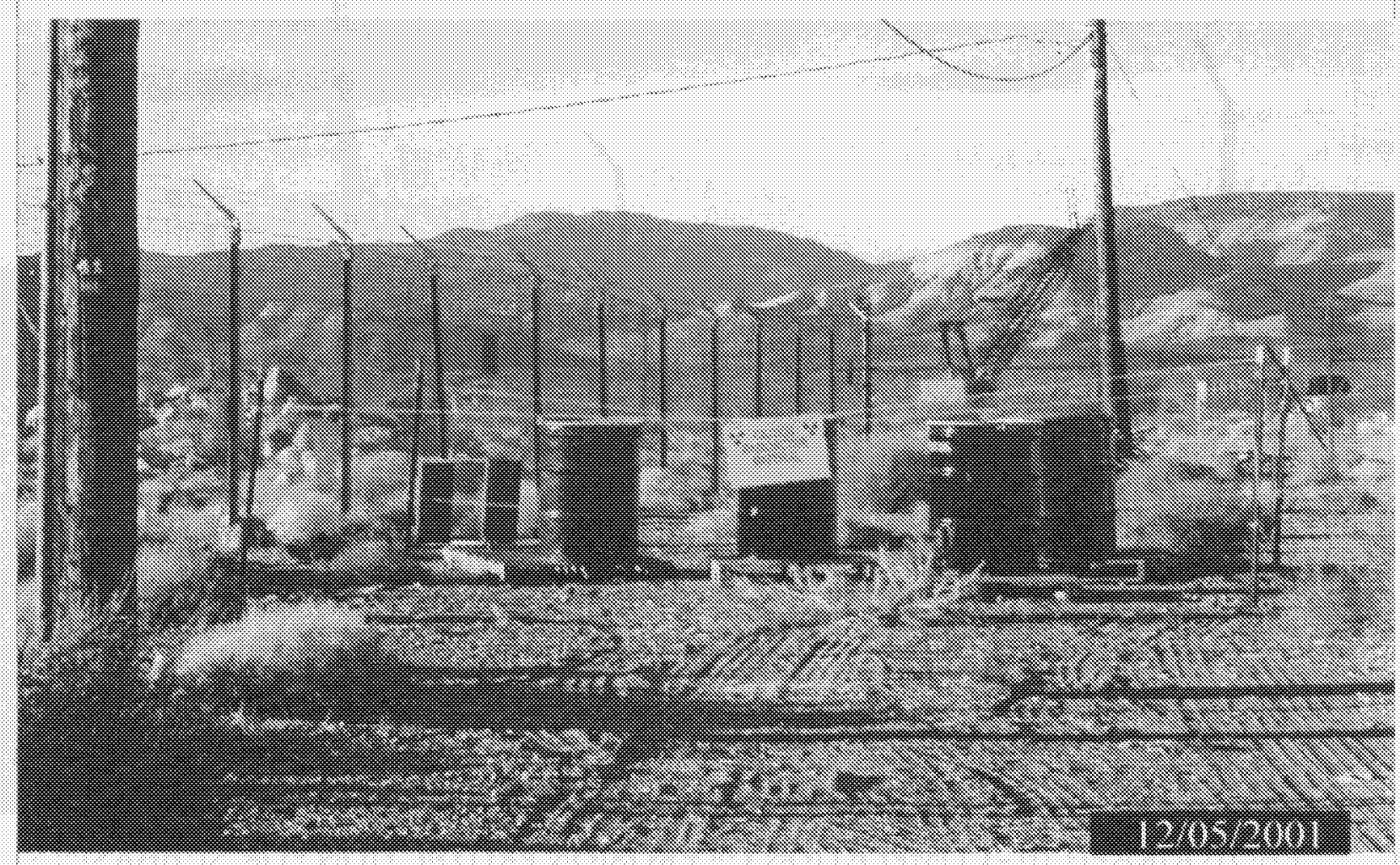

PWOTIOORAYH 12 - CONTANER STORAOE AREA FOR ST-90 IMPACTED SOII 


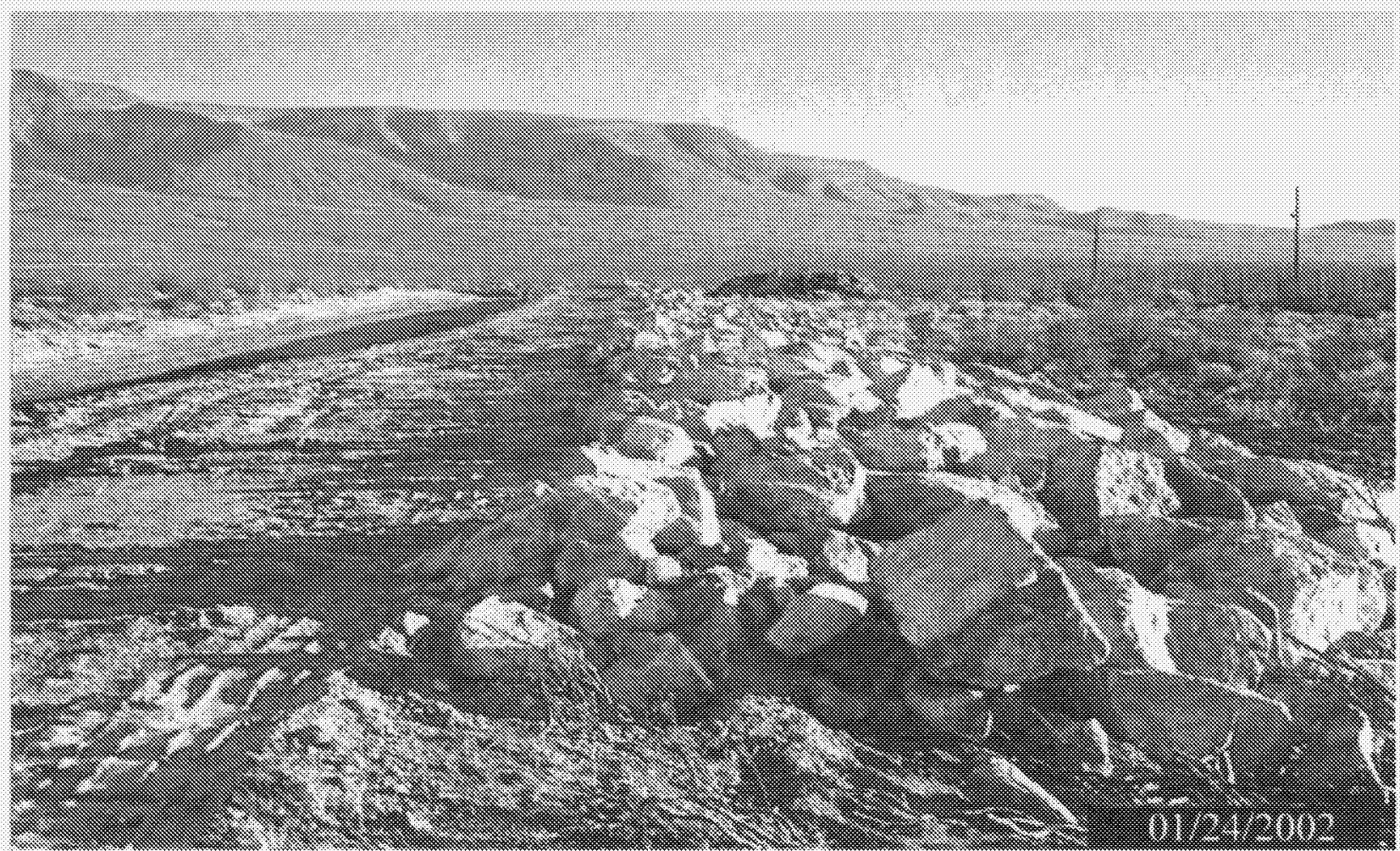

PHOTOORAPH I3 - COMPI ETION OF EROSION PROTECTION FOR SUEBASINS

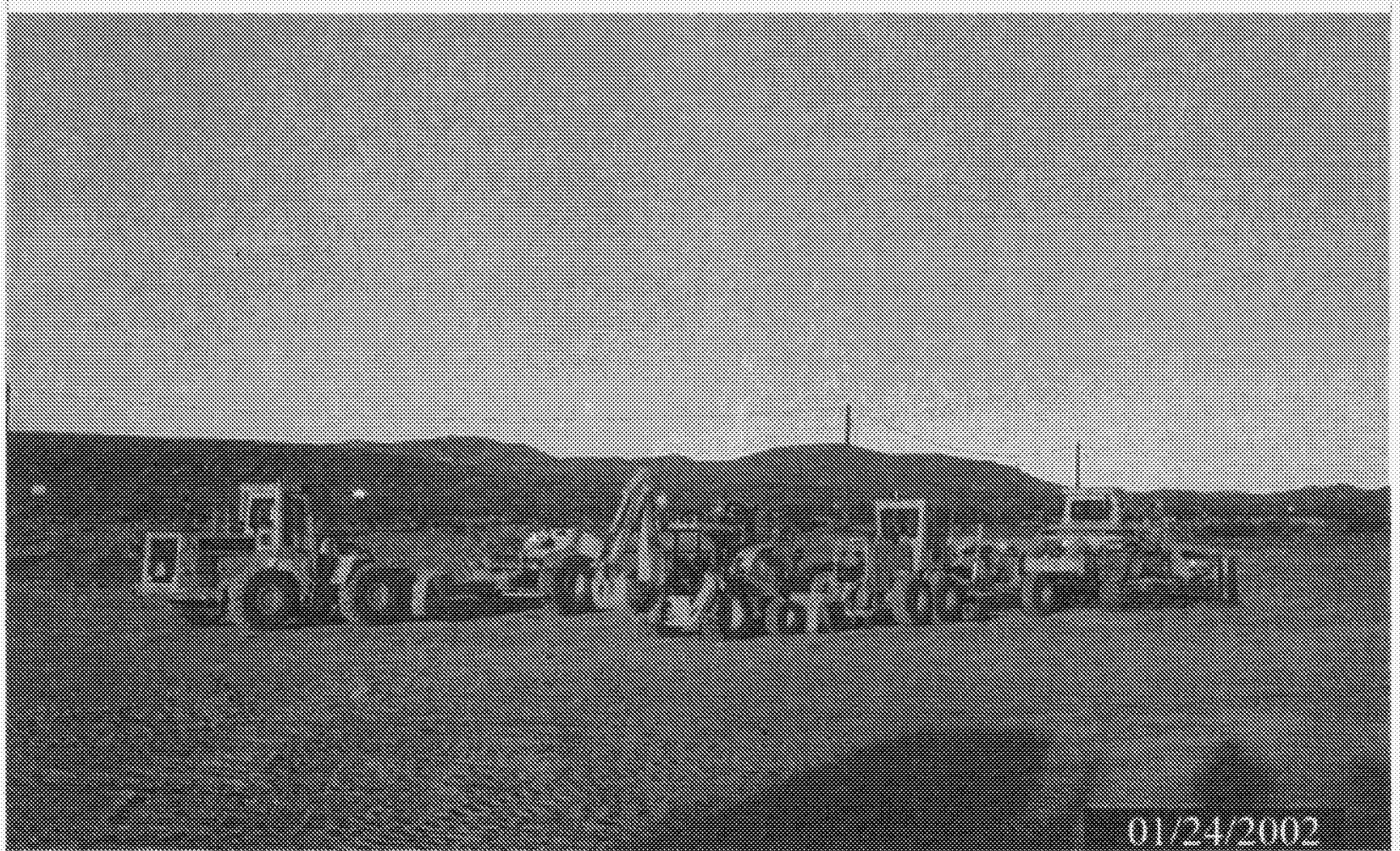

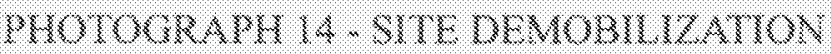




\section{APPENDIX H}

\section{NEVADA DIVISION OF ENVIRONMENTAL PROTECTION COMMENT RESOLUTION FORM}


Closure Repurl - CALL: j\$,

Setton: Appendis. ]l

Revision: Li

[batc: Malsh 2002

THIS PAGE NVTENTIONALLY L.EFT BLANK 


\section{NEVADA ENVIRONMENTAL RESTORATION PROJECT DOCUMENT REVIEW SHEET}

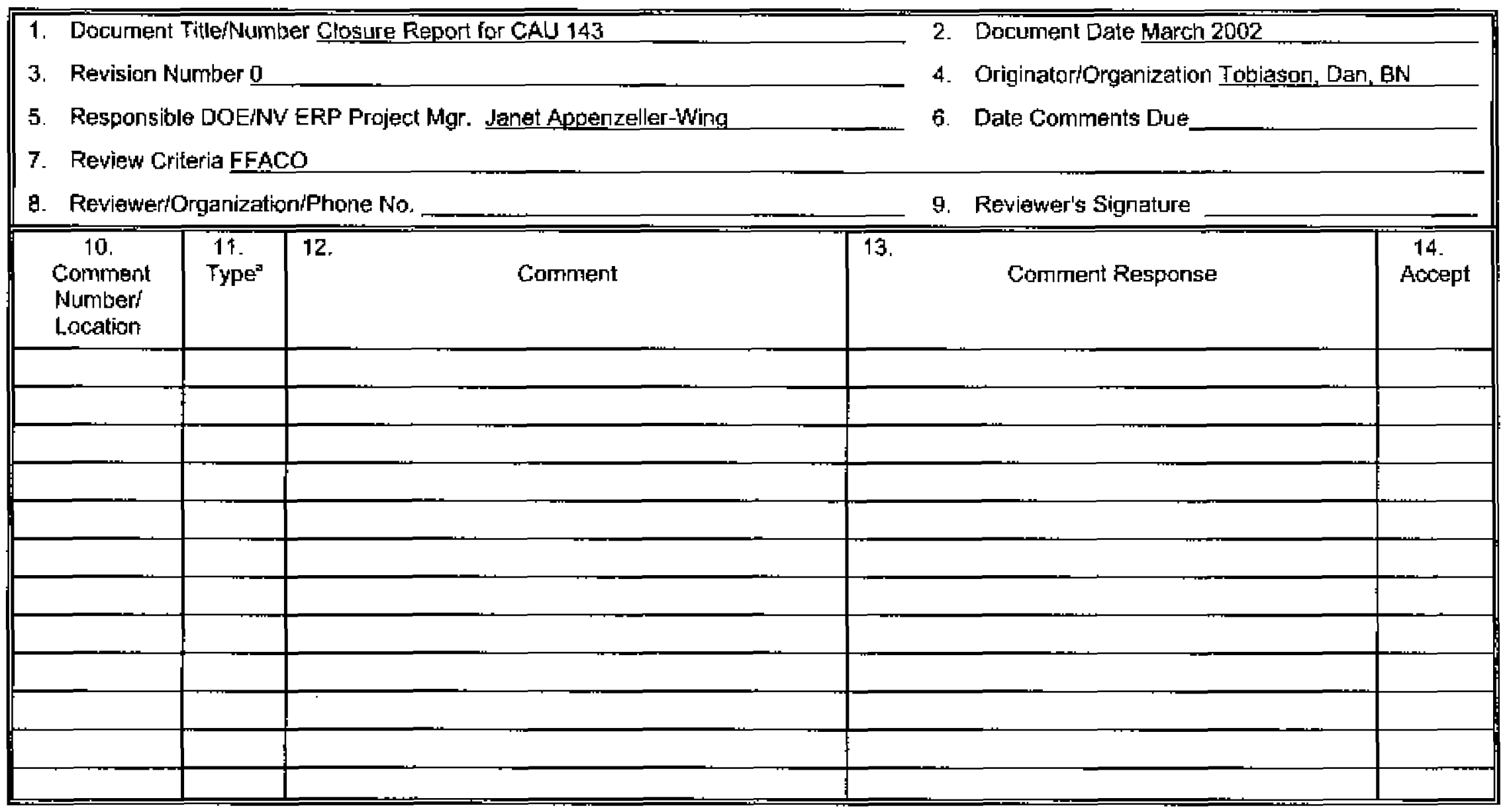

${ }^{3}$ Comment Types; $M=$ Mandatory, $s$ = Suggested.

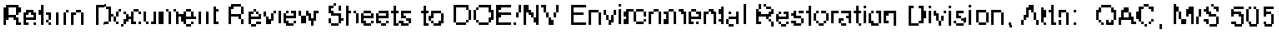




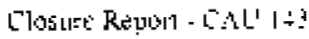

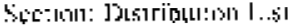

MeVI:ILTT: 0

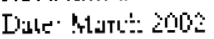

\section{DISTRIBUTION LIST}




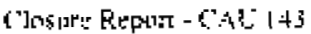
jectitrn: Distributan l.ís

Rerison: 0

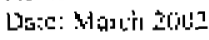

THIS PAGE INTENTIONALIY LEFT BLANK 


\section{DISTRIBUTION LIST}

*Provide copy of ithitial distribution of Revision 0 ; remainder of list gets Revision 0 if approved without changes. The entire list receives Revision 1, if issued.

\section{Nevada Department of Environmental Protection}

Donald Elle

Bureat of Federal Facilities

Division of Environmental Protection

1771 E. Flamingo, Suite 121-A

Las Vegas, NV 89119-0831

Paul Liebendorfer

Bureau of Federal Facilities

Division of Environjental Protection

333 W. Nye Lane, Room 138

Carson City, NV 89706-0866

\section{U.S. Department of Energy}

Janet Appenzeller-Wing

Environmental Restoration Division

L.S. Departmont of Energy

National Nuclear Security Administration

Nevada Operations Office

P.O. Box $98518 \mathrm{M} / \mathrm{S} 505$

Las Vegas, NV $89193-8518$

Sean Kosinski

Environmental Restoration Division

U.S. Department of Energy

National Nuclear Security Administration

Nevada Operations Office

P.O. Box $98518 \mathrm{M} / \mathrm{S} 505$

Las Vegas, NV 89193-8518

Sabrina Lawrence

Enหironmental Restoration Division

U.S. Department of Energy

National Nuclear Security Administration

Nevada Operations Office

P.O. Box $98518 \mathrm{M} / \mathrm{S} 505$

Las Vegas, NV 89193-8518
1 (Controlled)*

2 (Controlled)

1 (Uncontrolted)*

1 (Uncontrolled)*

1 (Controlled)* 


\section{DISTRIBUTION LIST (Continued)}

\section{L.S. Department of Energy (continued)}

Public Reading Facility

U.S. Department of Energy

National Nuclear Security Administration

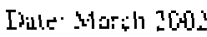

Nevada Operations Office

P.O. Box 98521 M/S NLV040

Las Vegas, NV 89193-8521

U.S. Department of Energy

National Nuclear Security Administration

1 (Uncontrol.ed)

Nevada Operations Office

Technical Information Resource Center

P.O. Box 98521 M/S 505

Las Vegas, NV 89193-8521

U.S. Department of Energy

Office of Scientific and Technical information

1 (Controlled) \&

1 (Uncontrolled)

175 Oak Ridge Tumpike

P.O. Box 62

Oak Ridge, TN 37831-0062

\section{Bechtel Nevada}

Cortespondence Control

Bechtel Nevada

P.O. Box $98521 \mathrm{M} / \mathrm{S}$ NLV008

Las Vegas, NV 89193-8521

Environmental Mariagement Library

I (Uncontrolled)*

Bechtel Nevada

P.O. Box $98521 \mathrm{M} / \mathrm{S}$ NL V080

Las Vegas, NV 89193-8521

Ann Heidema

1 (Uncontrolled)*

Bechtel Nevada

P.O. Box 98521 M/S NLV022

Las Vegas, NV 89193-8521

Steve Nacht

1 (Uncontrolled)*

Bechtel Nevada

P.O. Box 98521 M/S NTS306

Las Vegas, NV 89193-852!

(Uncontrolled)* 


\section{DISTRIBUTION LIST (Continued)}

\section{Bechte] Nevada (continued)}

Glenn Richardson

1 (Uncontrolled)*

Bechtel Nerada

P.O. Box $98521 \mathrm{M} / \$ \mathrm{NT} \$ 306$

Las Vegas, NT $89193-8521$

Jeffrey L. Smith

1 (Lncontrolled)*

Bochtel Nerada

P.O. Box 98521 M/S NTS306

Las Vegas, NV $89193-8521$

Dan Tobiason

Bechtel Nevada

I (Uncontrolled) ${ }^{\text {*t }}$

P.O. Box $98521 \mathrm{M} / \mathrm{S}$ NTS306

Las Vegas, NV 89193-8521

\section{IT Corporation}

Lynn Kidman

$l$ (Uncontrolled)*

IT Corporation

P.O. Box $93838 \mathrm{M} / \mathrm{S}$ NT\$439

Las Vegas, NV 89193-8521

IT FFACO Support Office

IT Corporation

1 (Controlled)

P.O. Box $93838 \mathrm{M} / \mathrm{S}$ NTS439

Las Vegas, NV $89193-8521$

\section{State of Nevada}

Manager, Northero Nerada

FFACO Public Reading Facility

1 (Controlled) \&

Nevada State Library and Archives Federal Publications

I (incontrolled)

100 North Stewart Street

Carson City, 89701-4285 